\title{
Site U1354
}

\author{
Expedition 317 Scientists $^{2}$
}

\section{Chapter contents}

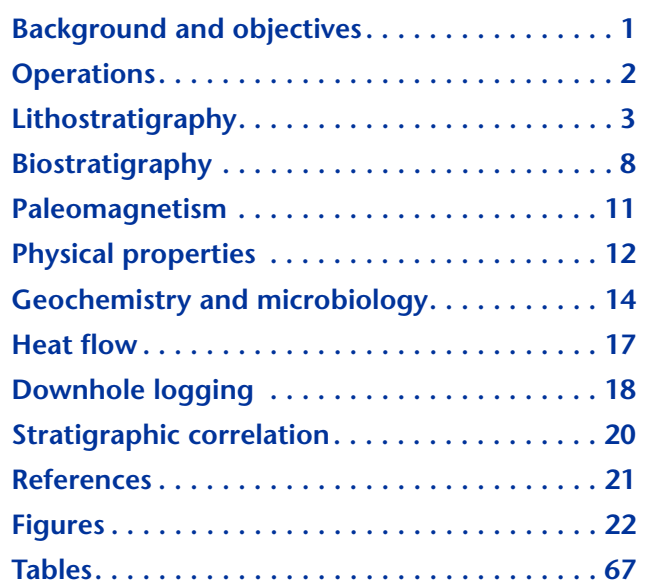

'Expedition 317 Scientists, 2011. Site U1354. In Fulthorpe, C.S., Hoyanagi, K., Blum, P., and the Expedition 317 Scientists, Proc. IODP, 317: Tokyo (Integrated Ocean Drilling Program Management International, Inc.). doi:10.2204/iodp.proc.317.106.2011

'Expedition 317 Scientists' addresses.

\section{Background and objectives}

\section{Hole U1354A}

Position: $44^{\circ} 50.8281^{\prime} \mathrm{S}, 171^{\circ} 47.2096^{\prime} \mathrm{E}$

Start hole: 0415 h, 29 December 2009

End hole: 2300 h, 29 December 2009

Time on hole $(\mathrm{d}): 0.78$

Seafloor (drill pipe measurement from rig floor, m DRF): 121.2 (APC mudline)

Distance between rig floor and sea level (m): 11.4

Water depth (drill pipe measurement from sea level, $\mathrm{m}$ ): 109.8

Total depth (drill pipe measurement from rig floor, $m$ DRF): 206.6

Total penetration (m DSF): 85.4

Total length of cored section $(\mathrm{m}): 83.4$

Total core recovered $(\mathrm{m}): 84.43$

Core recovery (\%): 101

Total number of cores: 18

\section{Hole U1354B}

Position: $44^{\circ} 50.8367^{\prime} \mathrm{S}, 171^{\circ} 47.2069^{\prime} \mathrm{E}$

Start hole: 2300 h, 29 December 2009

End hole: 1245 h, 30 December 2009

Time on hole (d): 0.57

Seafloor (drill pipe measurement from rig floor, m DRF): 124.8

(APC mudline)

Distance between rig floor and sea level (m): 11.4

Water depth (drill pipe measurement from sea level, $\mathrm{m}$ ): 113.4

Total depth (drill pipe measurement from rig floor, $m$ DRF): 202.0

Total penetration (m DSF): 77.2

Total length of cored section $(\mathrm{m}): 77.2$

Total core recovered $(\mathrm{m}): 77.52$

Core recovery (\%): 100

Total number of cores: 15

\section{Hole U1354C}

Position: $44^{\circ} 50.8487^{\prime} \mathrm{S}, 171^{\circ} 47.2080^{\prime} \mathrm{E}$

Start hole: 0700 h, 31 December 2009

End hole: 1200 h, 2 January 2010

Time on hole (d): 2.21 
Seafloor (drill pipe measurement from rig floor, $\mathrm{m}$ DRF): 124.8 (by proxy, Hole U1354B)

Distance between rig floor and sea level $(\mathrm{m}): 11.4$

Water depth (drill pipe measurement from sea level, $\mathrm{m}): 113.4$

Total depth (drill pipe measurement from rig floor, m DRF): 509.0

Total penetration (m DSF): 384.2

Total length of cored section $(\mathrm{m}): 319.2$

Total core recovered $(\mathrm{m}): 133.37$

Core recovery (\%): 42

Total number of cores: 35

Integrated Ocean Drilling Program (IODP) Site U1354 (proposed Site CB-02A) is located on the middle outer shelf (112 m water depth) within the Canterbury Bight between landward shelf Site U1353 (proposed Site CB-01A) and outer shelf Site U1351 (proposed Site CB-03B) within the Canterbury Basin drilling transect. Site U1354 is located on dip seismic Profile EW00-01-66 and crossing strike Profile EW0001-07a (Figs. F1, F2).

The philosophy behind the transect approach is discussed in "Background and objectives" in the "Site U1351" chapter. Site U1354 occupies an intermediate position in the shelf portion of the transect. Lithologies and paleoenvironments were therefore expected to be intermediate between those found at Sites U1351 and U1353.

Site U1354 penetrates a middle Miocene to Holocene section containing seismic sequence boundaries U8U19 (Lu and Fulthorpe, 2004). All sequence boundaries were penetrated landward of their rollovers or paleoshelf edges with the goal of recovering proximal facies, yielding evidence of shallow-water deposition, and providing optimal paleowater depths from benthic foraminiferal biofacies.

The principal objectives at Site U1354 were

1. To sample facies landward of rollovers of progradational seismic sequence boundaries U8-U19 and in particular to use benthic foraminiferal biofacies to estimate paleowater depths both above and below sequence boundaries in order to calculate eustatic amplitudes using two-dimensional backstripping.

2. To investigate the facies, paleoenvironments, and depositional processes associated with the sequence stratigraphic model in a proximal setting on a prograding continental margin where sequence architecture is well constrained by seismic imaging.

\section{Operations}

\section{Transit to Site U1354}

After a $7 \mathrm{nmi}$ transit from Site U1353, the R/V JOIDES Resolution was positioned over Site U1354 at $2320 \mathrm{~h}$ (all times are ship local time, Universal Time Coordinated [UTC] $+13 \mathrm{~h}$ ) on 28 December 2009. At $0001 \mathrm{~h}$ on 29 December, the positioning beacon (FSI BAP-547W, SN 1025, $14.0 \mathrm{kHz}, 200 \mathrm{~dB}$ ) was deployed. The position reference was a combination of Global Positioning System (GPS) and an acoustic beacon on the seafloor, weighted heavily toward the acoustic beacon (80\%).

\section{Site U1354 overview}

Three holes were cored with the advanced piston corer (APC)/extended core barrel (XCB) coring systems at Site U1354 (Table T1). The third hole (U1354C) was drilled to $65 \mathrm{~m}$ drilling depth below seafloor (DSF) with a center bit installed to advance the hole after severe weather ended Hole U1354B. Hole U1354C was then cored to 384.2 m DSF. Logging of Hole U1354C was successfully completed using a special tool configuration that combined the natural gamma ray tool, the sonic tool, and the resistivity tool. The Sediment Temperature (SET) tool was deployed twice without success. The type of formation encountered proved too difficult for our temperature measurement tools. Overall recovery for Site U1354 was $100 \%$ with the APC coring system and $39 \%$ with the XCB system. The total cored interval for Site U1354 was $479.8 \mathrm{~m}$, with $294.50 \mathrm{~m}$ (61\%) of recovery.

\section{Hole U1354A}

Rig floor operations commenced at $2345 \mathrm{~h}$ on 28 December when the vessel was stabilized over Hole U1354A. Coring in Hole U1354A (109.8 m water depth) began at $0415 \mathrm{~h}$ on 29 December, with $3.8 \mathrm{~m}$ of mudline core establishing the seafloor at $121.2 \mathrm{~m}$ drilling depth below rig floor (DRF). APC coring continued through Core $317-\mathrm{U} 1354 \mathrm{~A}-19 \mathrm{H}$ to $85.4 \mathrm{~m}$ DSF using nonmagnetic coring assemblies. A $2 \mathrm{~m}$ section (64.9-66.9 m DSF) had to be drilled to advance through a section of shells and shell fragments. Core orientation was measured on the first three cores, but hard formation and incomplete piston strokes prompted a decision to remove the tool. Temperature measurements were not attempted in this hole because hole conditions were poor and waiting for 10 min without circulation in shallow water was deemed too risky. Overall recovery for 
Hole U1354A using the APC coring system was $84.43 \mathrm{~m}(101 \%)$. The drill string was pulled back to the seafloor, and the bit cleared the seabed at $2300 \mathrm{~h}$ on 29 December, officially ending the hole.

\section{Hole U1354B}

The vessel was offset $20 \mathrm{~m}$ south of Hole U1354A, and Hole U1354B was spudded at $2330 \mathrm{~h}$. Hole U1354B was piston cored to $77.2 \mathrm{~m}$ DSF, with a total core recovery of $77.52 \mathrm{~m}(100 \%)$. Because of the rough piston coring conditions noted in Hole U1354A, the core orientation and downhole temperature tools were not deployed. Coring was terminated because highly variable winds from the south caused positioning problems. The ship could not be maintained in its required watch circle, so we decided to wait for the weather to improve. The drill string was tripped back to just above the seafloor, and the bit cleared the seafloor at $1245 \mathrm{~h}$ on 30 December, ending Hole U1354B.

\section{Hole U1354C}

Hole U1354C officially began at $0700 \mathrm{~h}$ on 31 December when the vessel could again be maintained in its watch circle over the new location. The ship was offset $20 \mathrm{~m}$ south of Hole U1354B, and coring began at $0715 \mathrm{~h}$ on 31 December. The hole was drilled with the center bit installed to $65 \mathrm{~m}$ DSF before two APC cores were taken. The core liner shattered on the second attempt, and the APC system was replaced with the XCB system to core through a particularly dense layer of shells. Core recovery with the XCB was initially very good but deteriorated downhole. Coring with the XCB continued to 384.2 $m$ DSF (Core 317-U1354C-36X). The total cored interval for Hole U1354C was $319.2 \mathrm{~m}$, with $133.37 \mathrm{~m}$ of core recovered $(42 \%)$.

The hole was swept clean with a $50 \mathrm{bbl}$ high-viscosity mud sweep and displaced with $320 \mathrm{bbl}$ of highviscosity $10.5 \mathrm{ppg}$ logging mud. The drill string was tripped out of the hole to $225 \mathrm{~m}$ DRF (100 m DSF). A special logging string was made up in order to combine all basic sensors without nuclear sources into a single run. The tool string included resistivity (Dual Induction Tool [DIT]), sonic compressional and shear velocity (Dipole Sonic Imager [DSI]), and natural gamma ray spectroscopy (Hostile Environment Natural Gamma Ray Sonde [HNGS]) tools. The tool string was rigged up in the early morning of 2 January 2010 and tagged the bottom of the hole at $\sim 505$ $\mathrm{m}$ wireline log depth below rig floor (WRF). A short "repeat section" was recorded from there to $\sim 440 \mathrm{~m}$ WRF. The tool string was returned to total depth, and then a main pass from total depth up to the sea- bed was recorded. The drill string was tripped back to $275 \mathrm{~m}$ DRF, and a $12 \mathrm{bbl}, 14 \mathrm{ppg}$ cement plug was pumped. At $0615 \mathrm{~h}$ on 2 January, the logging tools were rigged down, the drill string was tripped to the surface, and the bottom-hole assembly (BHA) was broken down and secured for transit. When the beacons were recovered and the rig was secured for transit, operations in Hole U1354C, at Site U1354, and on Expedition 317 ended at $1200 \mathrm{~h}$ on 2 January, and the vessel departed for the $24 \mathrm{~h}$ transit to Wellington.

\section{Lithostratigraphy}

Sediment descriptions at Site U1354, located between Site U1351 on the outer shelf and Site U1353 on the inner shelf, are based on three holes at this site. Holes U1354A and U1354B were drilled with the APC to 85.4 and $77.2 \mathrm{~m}$ core depth below seafloor (CSF-A), respectively (unless otherwise noted, all depths in this section are reported in $\mathrm{m}$ CSF-A). Hole $\mathrm{U} 1354 \mathrm{C}$ was drilled without coring to $65 \mathrm{~m}$. The APC system was then used to recover Cores 317$\mathrm{U} 1354 \mathrm{C}-2 \mathrm{H}$ and $3 \mathrm{H}$ before the hole was drilled with the XCB to a total depth of $384.2 \mathrm{~m}$. Holes U1354A and $\mathrm{U} 1354 \mathrm{~B}$ had a sediment recovery rate of $100 \%$, and Hole U1354C had a recovery rate of $41.8 \%$ (Fig. F3). These rates are slightly exaggerated given that some cores contain downhole material from cave-in or flow-in (at the base of some cores).

Lithologic descriptions at this site lack the X-ray diffraction (XRD) data used in other site descriptions, and similarly coulometry data are limited because of the short time frame available for drilling and the short transit at the end of the expedition.

The succession was divided into two lithologic units, with Unit I being further divided into two subunits (Table T2). Unit I (0-250 m) covers the Holocene to early Pliocene and is characterized by a highly heterogeneous assemblage of facies dominated by mud, with more heterogeneity evident in Subunit IA and a more repetitive succession of alternating facies occurring in Subunit IB. Unit II is early Pliocene in age and is primarily composed of mud, sandy mud, muddy sand, and rare marl layers, distinguished from Unit I by the generally low calcareous content of the layers.

The dominant mud lithology is interpreted as a shelf facies and likely represents the deepest water depth during deposition, so that the increasing dominance of mud facies downhole represents progressively deeper depositional environments. The other lithofacies present in Unit I are interpreted as shoreface or estuarine to inner shelf, possibly representing either 
transgressive shoreface deposits or sediment deposited immediately after the transgression (see Browne and Naish, 2003).

\section{Description of lithologic units}

\section{Unit I}

Intervals: Cores 317-U1354A-1H through 19H; 317-U1354B-1H through 15H; and 317U1354C-2H to Section 23X-CC, $20 \mathrm{~cm}$

Depths: Hole U1354A: 0-85.43 m (total depth); Hole U1354B: 0-77.52 m (total depth); and Hole U1354C: $65-250.86 \mathrm{~m}$

Age: Holocene to early Pliocene

Unit I is divided into Subunits IA and IB, which are described below. Unit I is heterolithic but characterized by its overall muddy composition (Figs. F4, F5). The uppermost part of the unit is well defined in Holes U1354A and U1354B (Fig. F6). The dominant lithology is dark greenish gray homogeneous mud (Fig. F7) with $<10 \%$ very fine sand beds/laminae. Shells are either rare and scattered or abundant and locally concentrated in layers as thick as $15 \mathrm{~cm}$ and beds $\sim 1 \mathrm{~m}$ thick. Shells are dominated by the gastropod Stirocolpus and lesser amounts of Tawera or other bivalves, including oysters. Some shell layers and beds contain shell fragments that range in size from a few millimeters to several centimeters. Contacts between shell layers are, for the most part, gradational with the overlying and underlying mud. Bioturbation is common and has an ichnofabric index of 1 (no bioturbation) to 5 (complete bioturbation). Locally, the mud fraction can be clay rich or clay (see "Lithostratigraphy" in the "Methods" chapter for definitions), the latter either forming centimeterthick, sharp-based beds or occurring as mottles within the mud (Fig. F8C).

\section{Subordinate lithologies include}

- Centimeter- to decimeter-thick beds of greenish gray and dark greenish gray very fine sandy shelly mud to shell hash (Fig. F8A) mixed with siliciclastic grains (very fine to medium sand) and abundant Stirocolpus, Tawera, echinoid spines, barnacle plates, bivalves, gastropods, and rare pebbles of graywacke sandstone as large as $1.5 \mathrm{~cm}$ in diameter and limestone as long as $7 \mathrm{~cm}$.

- Very dark greenish gray, well-sorted, very fine to fine (mostly fine), highly micaceous lithic sand with broken shells (Fig. F9). Typically, the sand has a soft and soupy appearance in the core and may have been partially fluidized during drilling.

- Sandy marl (Fig. F8A-F8B), which occurs as a $4 \mathrm{~m}$ thick deposit in the uppermost part of the site (Cores 317-U1354A-1H and 317-U1354B-1H), presumably of Holocene age. The sandy marl is homogeneous, dark greenish gray, and micaceous, with very fine to fine sand.

- Dark greenish gray clay-rich mud (Fig. F8D) with intercalated, normally graded sand laminations. Each lamination has a sharp base and is composed of very fine to fine, well-sorted, dark gray sand that is slightly micaceous and of possible Torlesse provenance. Rare, angular graywacke clasts (5-7 $\mathrm{mm}$ in diameter) are present in the mud.

- Bluish gray, poorly sorted, very fine to coarse sandy mud with abundant shells and shell fragments that range in size from $0-1 \mathrm{~mm}$ to $2 \mathrm{~cm}$.

- Calcareous muddy sand to sandy mud and concretions (Fig. F9D).

A considerable amount of potential cave-in material was recovered in Holes U1354A and U1354B below Sections 317-U1354A-5H-CC (14.3 m) and 317U1354B-4H-1 $(12.1 \mathrm{~m})$. The cores are typically capped by a shell-hash lithology in the top few decimeters that transitions, often through a soupy, mudrich interval, into what is considered to be in situ sediment. Despite the issue of cave-in and flow-in, a discernible stratigraphy of mud with subordinate clay, sand, sandy marl, and sandy mud is evident. Muddy shell hash and shelly mud cave-in first occur at the top of Core 317-U1354B-4H. Nannoplankton biostratigraphy shows that shell hash is definitely cave-in in Core 317-U1354A-11H (55 m). It is possible that the shell hash from $\sim 15 \mathrm{~m}$ to the occurrence listed above may represent in situ sediment.

Figure F6 illustrates the subtle variations in lithology, grain size, and shell content between Holes U1354A and U1354B, even though these holes are located 20 $\mathrm{m}$ from each other. Holes U1354A and U1354B can be correlated based on prominent sand and shelly mud beds. The sand intervals are thinner in Hole U1354B than in Hole U1354A. However, this could be an artifact of recovery because sand can be easily washed out from the bottom of APC cores. Both holes contain numerous shell beds, and a particularly thick example is present from 40 to $50 \mathrm{~m}$ in Hole U1354A and from 36 to $46 \mathrm{~m}$ in Hole U1354B (Fig. F6). In general, both holes show a coarseningupward trend dominated by sand in the uppermost $30 \mathrm{~m}$.

\section{Subunit IA}

Intervals: Cores 317-U1354A-1H through 19H; 317-U1354B-1H through 15H; and Sections $317-\mathrm{U} 1354 \mathrm{C}-2 \mathrm{H}-1,0 \mathrm{~cm}$, to $12 \mathrm{X}-1,110 \mathrm{~cm}$

Depths: Hole U1354A: 0-85.43 m (total depth); Hole U1354B: 0-77.52 m; and Hole U1354C: 65-145.8 m

Age: Holocene to mid-Pliocene 
Subunit IA is more heterolithic and contains dark greenish gray to olive-gray calcareous muddy sand, sandy marl, and homogeneous marl (e.g., Cores 317U1354A-1H and 317-U1354B-10H; Fig. F9A-F9B) and very dark gray, massive, quartz-rich, very well sorted very fine to fine sand (e.g., Cores 317U1354A-7H and 317-U1354B-10H; Figs. F6, F8B). This subunit also contains examples of sharp, bioturbated contacts between very fine muddy sand (sometimes calcareous) above and silty mud below (e.g., Sections 317-U1354B-13H-2 and 317-U1354C-12X-1; Fig. F9D).

Subunit IA at Site U1354, in common with the corresponding unit at all three other sites, is characterized by lithologic heterogeneity. The common lithologies are calcareous mud and calcareous sandy mud, which alternate with greenish gray shelly marl and sandy marl. Minor lithologies include very fine to fine sand, calcareous silty very fine to fine sand, and clay-rich mud. Most lithologies in Unit I contain $>10 \%$ carbonate components based on smear slide estimates (Fig. F10) and the identification of sand- to gravel-sized bioclasts in the cores.

The terrigenous components identified in smear slides are dominated by quartz and feldspar, micas (including chlorite, muscovite, and occasionally biotite), rock fragments, ferromagnesian minerals (probably mainly hornblende), and dense minerals (zircon and epidote, among others). Rock fragments identified at this site, in common with previous sites, include fine-grained metasedimentary and metamorphic rock fragments.

Authigenic components include varying amounts of opaque minerals (infilling foraminifers, framboids, nodules, and alteration of mica) and carbonate (incipient micritic/microcrystalline cement and alteration). Glauconite is common in a few horizons, notably around Section 317-U1354C-8X-CC, where unusual turquoise patches, as well as corroded shells and pale gray muddy sediment, were observed. The glauconite observed here is different from the majority of that observed at previous sites in that it appears to be composed primarily of the alteration of shell fragments (and possibly opaque minerals or mica grains) rather than transported grains. Layers with unusually high alteration or carbonate cements occur in association with sharp lithologic contacts, either in the shelly sandy layers above the contact (e.g., Sample 317-U1354C-10X-1, $70 \mathrm{~cm}$ ) or in the mud layers immediately below the contact (e.g., Sample 317-U1354A-11H-3, $37 \mathrm{~cm}$ ).

Biogenic components identified in smear slides are dominated by undifferentiated bioclasts (fragments of shells) in the sandy facies and by nannofossils and didemnid ascidian spicules in the muddy facies. Most shells, especially foraminifers, are altered, with calcite crystals growing on both the outside and inside of the shells.

All of the thin sections examined are from Subunit IA and belong to two different lithologies. The first lithology is sandy marlstone, in which cementation of the in situ sediment resulted in nodules or concretions. The cement comprises carbonate, either as matrix replacement or pore-filling cements (rhombic shapes are common). The other sediment components are generally the same as those in the surrounding sediments, with a slightly higher proportion of bioclasts and a lack of nannofossils (presumably from recrystallization). In one case (Section 317-U1354A-15H-CC), the cemented material comprises the interior of a shell, where cement is concentrated inside and around the shell, creating a nodule.

The second lithology identified in thin section is unusual and occurs in two isolated, bored cobbles, one of which was found in a core catcher sample (Section 317-U1354A-15H-CC) and the other in the shelly, sandy layer immediately above the Brunhes/Matuyama boundary (probably an unconformity; Sample 317-U1354B-13H-2, 77-78 cm; see "Paleomagnetism"). The cobbles are rounded and dark gray and have calcareous encrustations on the outside and extensive borings on their surfaces. The lithology of these samples is pyritized sandy or silty limestone. The matrix of each has been almost completely replaced by micrite, and opaque minerals (probably pyrite) occur throughout the matrix, concentrated around the margins of the borings. Sediment inside the borings is consistent with the surrounding sediment, but the lithified sediment inside the cobble itself is not consistent with the surrounding unlithified sediment. One of the differences noted is that although bioclasts (shell fragments and common foraminifers) occur within the limestones, specific bioclasts (mostly didemnid ascidian spicules) common to the surrounding and overlying sediments are not present. Burrowing in the sediment prior to cementation can be inferred by the occurrence of patches with no detrital grains, different cement texture, or randomly oriented detrital grains.

\section{Subunit IB}

Interval: Sections 317-U1354C-12X-1, $110 \mathrm{~cm}$, through 23X-CC, $20 \mathrm{~cm}$

Depth: $145.8-250.86 \mathrm{~m}$

Age: mid-Pliocene to early Pliocene

The Subunit IA/IB boundary is marked by a decrease in the percentage of ferromagnesian minerals and 
glauconite, as estimated in smear slides (Fig. F10). Subunit IB has a less varied lithology than that in Subunit IA; however, except for the above-mentioned differences, the overall composition observed in the smear slides is very similar. In this unit, the gray mud layers do not, in general, have very high carbonate component percentages and are only rarely calcareous.

Subunit IB lacks the aforementioned olive-gray marl and massive sand beds found in Subunit IA and is characterized by more repetitive assemblages of facies (e.g., Cores 317-U1354C-19X and 21X) that consist of (1) homogeneous greenish gray mud, which appears to be more clay rich (e.g., Sections 317U1354C-18X-1 and 14X-1; Fig. F8D) than that in Subunit IA and which also contains a minor calcareous component, and (2) greenish gray to gray calcareous sandy mud to sandy marl that often contains calcareous concretions (e.g., Section 21X-CC).

\section{Unit I/II boundary}

The main difference between Units I and II is the calcareous nature of each (Fig. F10): Unit II contains far fewer calcareous beds than Unit I and is dominated by a monotonous succession of gray sandy mud. The boundary is placed below the last highly calcareous layer and at the base of a sandy interval in the core.

\section{Unit II}

Interval: Sections 317-U1354C-23X-1 through 36X-CC

Depth: 250.10-375.38 m (total depth)

Age: early Pliocene

The sediments of Unit II are primarily composed of mud, sandy mud, muddy sand, and rare marl. In Unit II, the gray mud layers are not very calcareous, but they are also infrequent, and the unit is dominated by sandy mud (sometimes calcareous sandy mud). Greener layers with a sandier texture are still present. The percentage of carbonate in sandier greener layers, as estimated by smear slide observation, is much lower in Unit II than in Unit I and rarely exceeds $15 \%$. The dominant lithology is gray, homogeneous silty mud with rare scattered shells. Bioturbation has an ichnofabric index of 1 (no bioturbation) to 4 (heavy bioturbation).

\section{Correlation with wireline logs}

Wireline logging data and physical property measurements were not processed sufficiently by the end of the expedition to enable detailed correlation of the logs to the described lithostratigraphy.

\section{Downhole trends in sediment composition and mineralogy}

As at the other shelf sites, the compositional trends are gradational from Unit I to Unit II, but the lack of shipboard XRD data limits the description of downhole mineralogical trends. Unit I composition is highly variable depending on the lithology, which is consistent with the heterolithic nature of the unit. Quartz/feldspar, carbonate, clays, micas, ferromagnesian minerals, glauconite, rare dense minerals, and siliceous bioclasts occur throughout Unit I, but their concentrations are quite variable (Figs. F10). The carbonate, siliceous bioclast, and ferromagnesian mineral contents are notably higher in Subunit IA relative to deeper in the hole. However, no discernible downhole trends in composition are apparent in Subunit IB, and there are no recognizable changes in composition between Subunit IB and Unit II.

\section{Description of lithologic surfaces and associated sediment facies}

Because of time restrictions on board ship, surfaces were only examined close to the predicted depths of seismic sequence boundaries; therefore, the lithologic surfaces identified here are implicitly linked to the predicted occurrences of sequence boundaries identified on the seismic (Lu and Fulthorpe, 2004). A similar approach was used on board Ocean Drilling Program (ODP) Legs 150 and 174A, the objectives of which were also the study of sea level changes. Postcruise study will attempt to clarify the exact relationship of all lithologic surfaces and facies associations to sea level changes and seismic stratigraphy. The numbering system used in the site chapters, tables, and summary diagrams comprises a hole-specific prefix and a surface designation (e.g., U1354A-S1) that links each surface to a seismic sequence boundary; therefore, these lithologic surfaces and associated sediments are thought to be correlative between sites across the transect.

Definitions of Type A-C surfaces are detailed in "Lithostratigraphy" in the "Site U1352" chapter. Type A contacts and facies associations (sharp, commonly bioturbated basal contacts with overlying muddy shelly sand or sand beds $\sim 1 \mathrm{~m}$ thick) were identified in Holes U1354A-U1354C. This type of contact and facies association dominates the uppermost $250 \mathrm{~m}$ of sediments at this site. These contacts were classified as lithologic surfaces U1354A-S1 to U1354A-S5, U1354B-S1 to U1354B-S5, and U1354CS5 to U1354C-S8. One major characteristic of Site U1354 sediments is that in several intervals two or 
three Type A contacts and facies associations that could be used for correlation occur in one core. In such cases, the thickest bed was chosen.

\section{Surfaces U1354A-S1 to U1354A-S4 and U1354B-S1 to U1354B-S4}

Type A lithologic surfaces are present in the uppermost $64 \mathrm{~m}$ in Holes U1354A and U1354B (see Table T3 for associated depth intervals), revealing a very good correlation between holes. Surface depths differ across holes by as much as $4.8 \mathrm{~m}$ for U1354A-S4 and U1354B-S4 (Table T3). As at shelf Sites U1353 and U1351, very fine, well-sorted sand forms beds as thick as $9 \mathrm{~m}$, and these beds are associated with U1354A-S1 and U1354B-S1 (base of shelly sand layer) and U1354A-S2 and U1354B-S2 (debatable top of liquefied sand interval) (Fig. F11). The strongest correlation between holes is for surfaces U1354A-S4 and U1354B-S4, which were dated and correlated across holes by the Brunhes/Matuyama boundary.

\section{Surfaces U1354A-S5, U1354B-S5, and U1354C-S5}

Site U1354 is the only location at which three adjacent holes recovered surface $\mathrm{S} 5$ at comparable depths ranging from 74 to $80 \mathrm{~m}$ (Table T3). Muddy shelly Type A sand was recovered in each hole. However, a sharp burrowed contact was only recovered in Hole U1354C.

\section{Surfaces U1354C-S5.1 and U1354C-S6}

These two Type A surfaces are characterized by muddy shelly sand above a sharp contact that is bioturbated beneath. Surface U1354C-S5.1 is at $94 \mathrm{~m}$ and U1354C-S6 is at $118 \mathrm{~m}$. (Table T3). The Pliocene/Pleistocene boundary was picked by biostratigraphy between 122 and $133 \mathrm{~m}$, below U1354C-S6. Above this, the sediment age is between 1.73 and $1.81 \mathrm{Ma}(\mathrm{NN})$ and below this the age of the sediment is $>2.78 \mathrm{Ma}(\mathrm{NN})$.

\section{Surfaces U1354C-S7, U1354C-S7.1 and U1354C-S8}

A particular characteristic of outer shelf Site U1354 is the occurrence of several Type A contacts and facies associations within a few meters of each other. For example, sharp, burrowed contacts between shelly sand above and mud below that could be assigned to U1354C-S7 were found at 132, 146, and $163 \mathrm{~m}$.

U1354C-S7.1 is characterized by shelly sandy mud with a gradational lower contact containing concretions. This contact was placed at $181 \mathrm{~m}$.

U1354C-S8 is another example of multiple lithologic contacts occurring in a short interval of stratigraphy.
In all cases, the associated sediments are composed of shelly sandy marl. The sediment is more calcareous, and increased diagenesis and concretions are associated to this surface. Several lithologic contacts and associated sediments linked to U1354C-S8 are present at 218, 222, and $244 \mathrm{~m}$.

\section{Discussion and interpretation}

\section{Interpretation of Unit I}

Unit I represents a heterolithic assemblage whose deposition throughout was likely influenced by fluctuating sea level. The Type 1 and 2 cycles, as described in "Lithostratigraphy" in the "Site U1351" chapter, also occur at Site U1354.

The dominant homogeneous mud lithology is interpreted as a shelf facies and likely represents the deepest water depth during deposition. Benthic foraminifers in Subunit IA indicate fluctuations between estuarine or subtidal and middle shelf environments between 0 and $30 \mathrm{~m}$ (Cores 317-U1354A-7H and 317-U1354B-8H) and generally inner shelf to outer shelf environments (see "Biostratigraphy"). Intercalated, gray clay beds may represent episodic fluxes of fine-grained sediment derived from fluvial or glacial discharges.

We interpret the other lithologies within Unit I as shoreface or estuarine to inner shelf, particularly in the basal portions of the Type I and II cycles deposited during transgressive phases. We suggest that these lithologies represent either transgressive shoreface deposits or sediment deposited immediately after the transgression (Browne and Naish, 2003; see "Lithostratigraphy" in the "Site U1351" chapter). Shell-hash intervals likely formed in a shoreface and/or beach setting, and were probably also a transgressive shoreface deposit. The green sandy shelly mud may represent periods of late highstand and regression, when more calcareous sediment was deposited and perhaps when terrigenous sediment diminished. These conclusions are similar to our interpretation of lithologies within Unit I at Sites U1351 and U1353 (see "Lithostratigraphy" in the "Site U1351" chapter and "Lithostratigraphy" in the "Site U1353" chapter).

\section{Interpretation of Unit II}

Poor core recovery in Unit II may have resulted in a bias toward the recovery of muddy lithologies at the expense of other lithologies. The generally muddy character of the sediments means that they are difficult to interpret from a sedimentologic perspective. Benthic foraminifers indicate depositional water depths that range from inner to outer shelf (see "Biostratigraphy"). 
The generally mud-rich nature of the unit suggests a relatively quiet depositional setting on a shelf below a fair-weather wave base. Muddy sand may represent periods when more terrigenous sediment was supplied from the margin. Biostratigraphy reveals significant hiatuses (e.g., during the late Pliocene; see "Biostratigraphy") and suggests considerable periods of erosion that were likely caused by sea level and/or tectonic fluctuations that affected the shelf environment.

\section{Interpretation of lithologic surfaces and associated sediment facies}

Correlation at Site U1354 was found between Type A contacts and facies associations and the predicted depths of seismic sequence boundaries (Table T3). These lithologic contacts were found within 2-30 m of the predicted depths of sequence boundaries (Fig. F12). In some cases, several contacts and facies potentially correlate to each respective sequence boundary.

\section{Surfaces U1354A-S1 to U1354A-S4 and U1354B-S1 to U1354B-S4}

These surfaces are correlated to seismic sequence boundaries U19, U18, U17, and U16. The depths at which these surfaces occur and the predicted depths of U19-U16 exhibit good correlation, with minor offsets of $5 \mathrm{~m}$ for U1354A-S3 and U1354B-S3 and U1354A-S4 and U1354B-S4. The Brunhes/Matuyama boundary was located and correlated across Holes $\mathrm{U} 1354 \mathrm{~A}$ and U1354B between 65 and $69 \mathrm{~m}$, and the paleomagnetic age further contributed to the correlation of surfaces U1354A-S4 and U1354B-S4.

\section{Surfaces U1354C-S5, U1354A-S5, U1354B-S5, U1354C- S5.1, and U1354C-S6}

Type A surfaces and facies associations associated with U1354C-S5 were also identified in Holes U1354A and U1354B. These surfaces occur in the general depth range of U15, which has a predicted depth of $79 \mathrm{~m}$. Surface U1354C-S5 was picked at 75 $\mathrm{m}, \mathrm{U} 1354 \mathrm{~B}-\mathrm{S} 5$ was picked at $74 \mathrm{~m}$, and U1354A-S5 was picked at $80 \mathrm{~m}$. U1354C-S5.1 is correlated to $\mathrm{U14}$, which has a predicted depth of $93 \mathrm{~m}$. This surface is also present at Site U1352, where it is also correlated to U14. U1354C-S6, located at $118 \mathrm{~m}$, is correlated to U13, which has a predicted depth of 121 $\mathrm{m}$.

\section{Surfaces U1354C-S7, U1354C-S7.1, and U1354C-S8}

Type A contacts and facies associations related to U1354C-S7 occur at 132, 146, and $163 \mathrm{~m}$. The lithologic surface at $146 \mathrm{~m}$ is correlated to U12 at $156 \mathrm{~m}$. U1354C-S7.1 at $181 \mathrm{~m}$ is correlated to U11 at $177 \mathrm{~m}$.
Hole U1354C is the only location at which a lithologic surface was correlated to U11. Four Type A deposits (at 218, 222, and $244 \mathrm{~m}$ ) are related to surface U1354C-S8 and are potential lithologic surfaces of correlation for $\mathrm{U} 10$ at $211 \mathrm{~m}$. The surface at $218 \mathrm{~m}$ has been tentatively selected. Future studies will investigate in more detail the role of contrasting lithologies, overlying strata thicknesses, the number of events, and other potential sources that may generate seismic impedance contrast and acoustic signal.

\section{Biostratigraphy}

Holocene to late early Pliocene biostratigraphy of Site U1354 was based on the shipboard study of calcareous nannofossils, diatoms, and planktonic and benthic foraminifers in core catcher samples from Holes U1354A-U1354C (Table T4; Fig. F13). Additional intracore samples were taken from selected cores to address specific age and paleoenvironmental questions using calcareous nannofossils. All microfossil groups were represented throughout the cored section except for diatoms, which were found only in a few Pleistocene samples. All depths in this section are reported in $\mathrm{m}$ CSF-A.

Holocene to Pleistocene sections from Samples 317U1354A-1H-CC, $0 \mathrm{~cm}$, through 19H-CC (3.78-85.38 $\mathrm{m})$, 317-U1354B-1H-CC through 15H-CC (4.06$77.25 \mathrm{~m}$ ), and 317-U1354C-2H-CC through 10X-CC (72.57-127.79 $\mathrm{m}$ ) were primarily dated and divided into Zones NN21-NN19 using calcareous nannofossils. Two hiatuses were identified with nannofossil dating: (1) an intra-Pleistocene hiatus between Samples 317-U1354A-15H-CC and 17H-CC (76.20-80.16 $\mathrm{m})$ and between 317-U1354B-15H-1, $15 \mathrm{~cm}$, and $15 \mathrm{H}-1,39 \mathrm{~cm}(73.65-73.89 \mathrm{~m})$, where $\sim 0.3 \mathrm{~m} . \mathrm{y}$. was missing, and (2) a hiatus at the base of the Pleistocene between Samples 317-U1354C-9X-CC and 10XCC (122.20-133.37 m), where $\sim 1 \mathrm{~m} . \mathrm{y}$. was missing. Another potential hiatus was identified on the basis of calcareous nannofossil dating and magnetostratigraphic data in Holes U1354A and U1354B at 69.90 and $64.75 \mathrm{~m}$, respectively.

The Pliocene section between Samples 317-U1354C10X-CC and 36X-CC (133.37-375.33 m) was poorly dated, but calcareous nannofossil and planktonic foraminifer biostratigraphy suggested an age of middle Pliocene (older than $2.78 \mathrm{Ma}$, calcareous nannofossils) to late early Pliocene (younger than $4.3 \mathrm{Ma}$, planktonic foraminifers). There was no biostratigraphic evidence for the late Pliocene, which was probably missing at the level of the Pleistocene-Pliocene hiatus.

Benthic foraminiferal abundances were generally indicative of subtidal to middle shelf depths through- 
out the Pleistocene, and planktonic foraminifers suggested that deposition occurred generally under sheltered, inner neritic conditions with short-lived excursions to outer neritic and extraneritic conditions. Pliocene deposition occurred generally at inner shelf water depths (and possibly middle shelf depths) under sheltered, inner neritic conditions.

\section{Calcareous nannofossils}

Nannofossil assemblages at Site U1354, located on the outer shelf, were typically common to abundant and moderately to well preserved (Table T5). The Pleistocene succession was robustly dated by nannofossil biostratigraphy (Table T4). Although standard zonal markers were absent for the Pliocene section, the Reticulofenestra lineage provided crude, though critical, age control for this interval.

\section{Holocene-Pleistocene}

Although not identified biostratigraphically, the base of the Holocene was tentatively placed at Section $317-\mathrm{U} 1354 \mathrm{~A}-2 \mathrm{H}-1,25 \mathrm{~cm}(4.03 \mathrm{~m})$, where there was a distinct lithologic change between greenish gray marly sands and gray calcareous muds.

The lowest occurrence (LO) of Emiliania huxleyi (0.29 Ma; base of Zone NN21) was observed between Samples 317-U1354A-6H-4, $0 \mathrm{~cm}$, and 6H-CC (20.80$24.25 \mathrm{~m}$ ) and between 317-U1354B-7H-CC and 8HCC (26.50-33.45 m). The discrepancy in the location of this datum between Holes U1354A and U1354B is most likely due to the rare nature of this species at its inception and the paucity of nannofossils in the fine sands in Samples 317-U1354A-6H-CC and 7H-CC (24.25-31.33 m).

The highest occurrence (HO) of zonal marker Pseudoemiliania lacunosa (0.44 Ma; top of Zone NN19) was identified between Samples 317-U1354A-12H-1, $6 \mathrm{~cm}$, and $12 \mathrm{H}-6,31 \mathrm{~cm}(56.36-64.11 \mathrm{~m})$, and between 317-U1354B-11H-CC and 12H-CC (57.73$62.44 \mathrm{~m})$.

An intra-Pleistocene hiatus was noted between Samples 317-U1354A-15H-CC and 17H-CC (76.20-80.16 $\mathrm{m})$. In Hole U1354B, this hiatus was identified between Samples 317-U1354B-15H-1, $15 \mathrm{~cm}$, and 15H1, $39 \mathrm{~cm}(73.65-73.89 \mathrm{~m})$. In Hole U1354C, it was observed between Samples 317-U1354C-2H-CC and $4 \mathrm{X}$-CC $(72.57-84.37 \mathrm{~m})$. This was evidenced by the occurrence of Gephyrocapsa $>5.5 \mu \mathrm{m}(1.26 \mathrm{Ma})$ at this level and the absence of Reticulofenestra asanoi (0.91$1.14 \mathrm{Ma}$ ), suggesting a hiatus of $\sim 0.3 \mathrm{~m}$.y. This hiatus was similarly observed at Sites U1351 and U1353, representing a robust surface of correlation between these sites. In addition, the first paleomagnetically reversed sediments were observed at 69.90 and
$64.75 \mathrm{~m}$ (Holes U1354A and U1354B, respectively), interpreted to represent the Brunhes/Matuyama boundary (see "Paleomagnetism"). This boundary is likely unconformable, although the amount of time missing is unknown.

The HO of Helicosphaera sellii (1.34 Ma) was distinguished between Samples 317-U1354A-18H-CC and 19H-CC (80.33-85.38 m) and 317-U1354C-4X-CC and 5X-CC (84.37-86.84 m). The LO of Gephyrocapsa $>4 \mu \mathrm{m}$ (1.69 Ma) was recognized between Samples 317-U1354C-6X-CC and 7X-CC (97.76-105.86 m). Lastly, the LO of Gephyrocapsa caribbeanica (1.73 Ma) was observed between Samples 317-U1354C-8X-CC and 9X-CC (111.56-122.20 m).

\section{Pliocene}

The Pliocene/Pleistocene boundary was biostratigraphically picked using calcareous nannofossils between Samples 317-U1354C-9X-CC and 10X-CC (122.20-133.37 m). This pick correlates with a sharp lithologic boundary noted in Core 317-U1354C-10X. Site U1354 is the only expedition shelf site where this boundary was definitely recovered. Nannofossil abundances dropped dramatically across the Pliocene/Pleistocene boundary, a trend that was similarly observed at all three shelf sites. Sample 317U1354B-12H-CC (152.98 m) contained specimens of Reticulofenestra ampla, the $\mathrm{HO}$ of which was dated at $2.78 \mathrm{Ma}$ (Kameo and Bralower, 2000), suggesting an unconformable Pliocene/Pleistocene boundary where the late Pliocene is missing.

Nannofossil abundances in the Pliocene section were variable and ranged from barren to common, and preservation was generally good. Biostratigraphic analysis of Site U1354 Pliocene sediments was particularly problematic for all microfossil groups because of low abundances and/or the absence of biostratigraphic markers.

The HO of Reticulofenestra pseudoumbilicus (3.70 Ma) occurred between Samples 317-U1354C-16X-CC and 17X-CC (183.20-192.75 m), defining the boundary between the middle and early Pliocene. An expanded early Pliocene section was recovered from Hole U1354C, and the lowermost core catcher contained specimens of the planktonic foraminifer Globoconella puncticuloides s.s., restricting the age to younger than 4.3 Ma. Bottom-hole age was therefore constrained between 3.7 and $4.3 \mathrm{Ma}$.

\section{Planktonic foraminifers}

Holocene to late early Pliocene planktonic foraminiferal biostratigraphy of outer shelf Site U1354 was based on the examination of core catcher samples from Holes U1354A-U1354C (Tables T6, T7, T8, T9, 
T10, T11). Absolute ages assigned to biostratigraphic datums follow the references listed in Table T3 in the "Methods" chapter. Planktonic foraminifers were present in most samples in the Holocene to Pleistocene succession, but abundances were generally low. Preservation was generally good. For planktonic foraminiferal abundance and interpretation of oceanicity, see Tables T6, T7, and T8 and Figure F14.

\section{Holocene}

Mudline samples (317-U1354A-1H-1, $0 \mathrm{~cm}$ [0.00 m], and $317-\mathrm{U} 1354 \mathrm{~B}-1 \mathrm{H}-1,0 \mathrm{~cm}[0.00 \mathrm{~m}]$ ) were characterized by abundant planktonic foraminiferal assemblages with common temperate taxa interpreted to have been deposited under extraneritic conditions. Although not identified biostratigraphically, the base of the Holocene was tentatively located at Section $317-\mathrm{U} 1354 \mathrm{~A}-2 \mathrm{H}-1,25 \mathrm{~cm}(4.03 \mathrm{~m})$, at the level of distinct lithologic change between greenish gray marly sands and gray calcareous muds.

\section{Pleistocene}

Planktonic foraminiferal assemblages in the Pleistocene sections of Samples 317-U1354A-1H-CC through 19H-CC (3.78-85.38 m), 317-U1354B-1HCC through 15H-CC (4.06-77.25 m), and 317U1354C-2H-CC through 10X-CC (72.57-133.37 m) were characterized by small, thin-walled neritic forms. Deposition generally occurred under sheltered inner neritic conditions, except in Samples 317-U1354A-5H-CC (14.69 m), 8H-CC through 11HCC (38.14-60.14 m), and 317-U1354B-7H-CC through 12H-CC (26.50-62.44 m), where planktonic abundances ranged from $10 \%$ to $51 \%$, indicating deposition under inner neritic to extraneritic conditions. Peaks in abundance were generally associated with greenish gray sandy marls, and the assemblages included common temperate forms such as Globoconella inflata, Neogloboquadrina incompta, and Orbulina universa. Intervals of gray calcareous muds interbedded with sandy marls contained colder water assemblages, although the abundance of the subantarctic species Neogloboquadrina pachyderma was seldom high. Other species found in Pleistocene samples included abundant Globigerina bulloides, Globigerina spp., Turborotalita quinqueloba and related forms, and rare Globigerinita glutinata. Single specimens of the subtropical species Globigerinoides ruber (Sample 317U1354B-12H-CC [62.44 m]) and Globigerinella aequilateralis (Sample 317-U1354A-11H-CC [60.14 m]) were also present.

Planktonic foraminifers were too few for reliable dating, but the presence of Truncorotalia truncatulinoides in Samples 317-U1354A-8H-CC (38.14 m) and 10HCC $(53.76 \mathrm{~m})$ indicated that the uppermost part of the section was younger than 1.1 Ma. The late Pleistocene, Haweran/Castlecliffian Stage boundary was identified between Samples 317-U1354B-9H-CC and $10 \mathrm{H}-\mathrm{CC}(41.46-50.29 \mathrm{~m})$ on the basis of the HO of benthic foraminifer Siphotextularia wairoana. Calcareous nannofossil dating supported this correlation. The base of the Pleistocene was identified using calcareous nannofossil evidence between Samples 317U1354C-9X-CC and 10X-CC (122.20-133.37 m).

\section{Pliocene}

Pliocene planktonic foraminiferal abundances between Samples 317-U1354C-11X-CC and 36X-CC $(144.95-375.33 \mathrm{~m})$ seldom reached $>5 \%$ of the total foraminiferal assemblage. Assemblages were generally composed of small, thin-walled neritic forms, and diversity was low, except in Sample 317U1354C-21X-CC $(240.77 \mathrm{~m})$, where planktonic abundance reached $21 \%$. This sample included abundant small Globigerina spp., Globigerina bulloides, Neogloboquadrina pachyderma, and Nq. incompta. These species were also present in most of the Pliocene section along with sporadic occurrences of Turborotalita quinqueloba.

Several age-diagnostic species were also found in the lower part of the Pliocene section, including Globoconella inflata and Gc. puncticuloides. The $\mathrm{HO}$ of Zeaglobigerina woodi (2.7 Ma) was noted between Samples 317-U1354C-27X-CC and 28X-CC (293.32-299.64 $\mathrm{m})$, although calcareous nannofossil dating suggested that this bioevent was suppressed at this site. The joint occurrence of $\mathrm{Zg}$. woodi and Gc. puncticuloides in the lowermost Sample 317-U1354C-36X-CC $(375.33 \mathrm{~m})$ indicated a late early Pliocene age of 2.74.3 Ma for the hole bottom. Calcareous nannofossils indicated that bottommost sediments were older than $3.7 \mathrm{Ma}$, constraining the bottom-hole age to 3.7-4.3 Ma.

\section{Benthic foraminifers}

Sixty-five core catcher samples from Holes U1354AU1354C were examined for benthic foraminifers (Table T12). Three samples identified by nannofossil biostratigraphy as caved (Table T5) were not used for biostratigraphic and paleowater depth assessments. Benthic foraminifer abundance varied throughout the cored interval. Preservation was generally good (but occasionally moderate or poor) in the Pleistocene and varied from poor to good in the Pliocene. Three benthic foraminiferal bioevents were identified at Site U1354 (Table T4). 


\section{Holocene-Pliocene}

The HO of Siphotextularia wairoana (0.34 Ma) was observed between Samples 317-U1354A-9H-CC and 10H-CC (46.88-53.76 m) and between 317-U1354B9H-CC and 10H-CC (41.46-50.29 m). Proxifrons advena $(\mathrm{HO}=\sim 0.4 \mathrm{Ma}$; Hayward, 2001) was also identified between Samples 317-U1354A-9H-CC and 10HCC (46.88-53.76 m). The HO of Bolivinita pliozea $(\sim 0.6 \mathrm{Ma})$ was identified between Samples 317U1354A-12H-CC and 13H-CC (64.90-73.44 m) and between 317-U1354B-10H-CC and 11H-CC (50.29$57.73 \mathrm{~m}$ ). This species was also observed in the uppermost core catcher sample in Hole U1354C (2HCC [72.57 m]), suggesting an age older than 0.6 Ma. These ages are in general agreement with Pleistocene ages derived from calcareous nannofossils. The HO of Haueslerella parri (1.63 Ma) was seen in Sample 317-U1354C-12X-CC (152.98 $\mathrm{m})$ below the Pliocene/Pleistocene boundary.

\section{Paleowater depths}

Estimated paleowater depths are given in Table T12 and Figure F15. The paleodepth zone classification is given in Figure F7 in the "Methods" chapter.

In the Pleistocene section, two alternating benthic foraminiferal assemblages were noted (Holes U1354A and U1354B and Samples 317-U1354C-1H-1, $0 \mathrm{~cm}$, through 9X-CC [0-122.20 m]). One assemblage consisted mainly of Notorotalia inornata (shallow inner shelf) and Elphidium charlottense (estuarine-subtidal) associated with Zeaflorilus parri (shallow inner shelf), suggesting a shallow inner shelf environment. The other assemblage consisted of Notorotalia aucklandica (inner shelf), Nonionella flemingi, and Anomalinoides sphericus (middle outer shelf), implying a depositional environment as deep as outer shelf. Samples 317-U1354A-8H-CC through 11H-CC (38.14-60.14 $\mathrm{m})$ and 317-U1354C-8X-CC $(111.56 \mathrm{~m})$ contained the uppermost bathyal taxon Globocassidulina subglobosa. Paleowater depths exhibited high variability from subtidal to outer shelf environments, with maximum water depths in the late and earliest Pleistocene.

In the middle Pliocene section between Samples 317U1354C-10X-CC and 22X-CC (133.37-247.41 m), benthic foraminifers were rare and poorly preserved. Notorotalia flemingi, N. aucklandica, and N. inornata (inner to middle shelf) were relatively common in association with Bolivina spp. and Astrononion spp., suggesting inner shelf environments.

In the lower Pliocene section between Samples 317U1354C-21X-CC and 36X-CC (240.77-375.33 m), the benthic assemblage was characterized by Notorotalia flemingi, N. aucklandica, N. inornata, and As- trononion spp. (inner to middle shelf), together with consistent occurrences of Uvigerina rodleyi (inner to middle shelf; Hornibrook et al., 1989) and Anomalinoides sphericus (middle to outer shelf). This suggested middle shelf environments that shallow occasionally to inner shelf the early Pliocene.

\section{Diatoms}

Eighteen core catcher samples from Hole U1354A were examined for diatoms (Samples 317-U1354A1H-CC through 19H-CC [3.78-85.38 m]) (Table T13). Diatom samples were typically barren, except in Sample 317-U1354A-2H-CC (12.26 m), where diatoms were common and moderately preserved. This assemblage consisted of extant coastal taxa, along with Paralia sulcata ( $>90 \%$ in abundance), resting spores of Chaetoceros, a fragment of Triceratium spp., and Paralia sulcata. Rare resting spores were also present in Samples 317-U1354A-4H-CC (14.30 m), 9H-CC (46.88 m), and 14H-CC (75.41 m).

All core catcher samples (317-U1354B-1H-CC through 15H-CC [4.06-77.25 m] and 317-U1354C$2 \mathrm{H}-\mathrm{CC}$ through $36 \mathrm{X}-\mathrm{CC}$ [72.57-375.33 m]) were barren of diatoms, except for Sample 317-U1354B-10HCC $(50.29 \mathrm{~m})$, which contained two valves of the coastal species Paralia sulcata, as well as several fragments from other indeterminate species (Table T13).

\section{Macrofossils}

Macrofossils were examined in cored sediments from all Site U1354 holes. Provisional identifications, ages, and habitat preferences are provided in Table T14.

\section{Paleomagnetism}

Paleomagnetic analyses at Site U1354 included measurement and partial demagnetization of natural remanent magnetization (NRM) of archive section halves. No discrete samples from Site U1354 were measured during shipboard analyses. All depths in this section are reported in $\mathrm{m}$ CSF-A.

\section{Section-half measurements}

NRM was measured on archive section halves from Holes U1354A-U1354C before and after demagnetization at $20 \mathrm{mT}$ peak fields. Persistent flux jumps in the superconducting rock magnetometer (SRM) made measurements difficult at Site U1354. Many section halves were measured several times before readings were accepted. Because of the limited time available, no acceptable measurement could be obtained for some sections, whereas for others only 
NRM was recorded. In spite of this, a good record of all three holes from Site U1354 was acquired.

Holes U1354A and U1354B have similar total depths, and comparable records were obtained (Figs. F16, F17). These relatively shallow holes were cored using the APC system with nonmagnetic core barrels throughout. Hole U1354C was drilled without coring for $65 \mathrm{~m}$, at which point the APC system was used with nonmagnetic core barrels to recover two cores overlapping the bases of Holes U1354A and U1354B. Coring continued with the XCB system to total depth (Fig. F18).

$\mathrm{NRM}$ intensities typically vary between $10^{-2}$ and $10^{-3}$ $\mathrm{A} / \mathrm{m}$, and some anomalous peaks were recorded that correspond to intervals of high magnetic susceptibility and cave-in. However, because of the difficulty of taking measurements, many of these sections were not measured in the SRM.

NRM inclinations from Site U1354 are typically steeply positive $\left(\sim 80^{\circ}\right)$, consistent with the drilling overprint observed at previous sites. In the upper parts of Holes U1354A and U1354B, these inclinations demagnetized at $20 \mathrm{mT}$ to fairly steeply negative inclinations. Declinations throughout this interval are consistent within cores and variable between cores, and they do not change direction significantly with demagnetization, suggesting a negligible radial drilling overprint. NRM declinations in Hole U1354C are clustered in the northern hemisphere and appear to display a drilling overprint associated with the standard steel core barrels used with the XCB coring system.

Reversed polarity was observed after $20 \mathrm{mT}$ demagnetization toward the base of Holes U1354A (from $69.9 \mathrm{~m}$ ) and $\mathrm{U} 1354 \mathrm{~B}$ (from $64.75 \mathrm{~m}$ ) and at the top of Hole U1354C. Inclinations remain steeply positive after demagnetization. Where the normal/reversed boundary is observed (Cores 317-U1354A-13H and 317-U1354B-13H), declinations change within the core. In each hole, this boundary corresponds with a lithologic boundary where green, muddy very fine sand overlies gray silty mud at an irregular contact.

The polarity reversal observed at the base of Holes U1354A and U1354B is the only one observed at Site U1354. Older sediments were recovered from Hole U1354C, but the drilling overprint imparted by the $\mathrm{XCB}$ system was not removed by $20 \mathrm{mT}$ demagnetization.

\section{Magnetostratigraphy}

Normal polarity sediments from the Brunhes Chron were identified from 0 to $69.9 \mathrm{~m}$ in Hole U1354A and from 0 to $64.75 \mathrm{~m}$ in Hole U1354B. These sediments are underlain across a lithologic boundary by reversed polarity (Matuyama) sediments. The exact amount of time represented by this boundary is unknown, but it includes the Brunhes/Matuyama boundary $(0.78 \mathrm{Ma})$ and is constrained by biostratigraphic evidence. Sediments overlying the boundary are older than $0.44 \mathrm{Ma}$, as indicated by the $\mathrm{HO}$ of Pseudoemiliania lacunosa between 56.36 and $64.11 \mathrm{~m}$ in Hole U1354A and between 56.36 and $64.11 \mathrm{~m}$ in Hole U1354B. Underlying sediments contain a nannofossil assemblage similar to that above the boundary (suggesting that any hiatus is brief) and lack Reticulofenestra asanoi $(\mathrm{HO}=0.91 \mathrm{Ma})$.

Further nannofossil evidence suggests that the bases of Holes U1354A and U1354B are older than $1.26 \mathrm{Ma}$ (HO Gephyrocapsa $>5.5 \mu \mathrm{m}$ is between 76.20 and $80.16 \mathrm{~m}$ in Hole U1354A and between 73.65 and $73.89 \mathrm{~m}$ in Hole U1354B). The Jaramillo normal Chron (C1r.1n $=0.998-1.072 \mathrm{Ma})$ was not recorded at Site U1354 and is likely represented by a second hiatus. This concurs with the absence of Reticulofenestra asanoi (total range $=0.91-1.14 \mathrm{Ma}$ ).

\section{Physical properties}

At Site U1354, gamma ray attenuation (GRA) densitometer bulk density, magnetic susceptibility (loop sensor; MSL), natural gamma radiation (NGR), and $P$-wave logger (PWL) velocity were measured on whole-round core sections from Holes U1354AU1354C. Discrete $P$-wave velocity measured using the $P$-wave caliper (PWC) and $P$-wave bayonets (PWB), moisture and density (MAD), and sediment strength were measured on section halves from Holes U1354B and U1354C. Magnetic susceptibility (point sensor; MSP) and spectrophotometry and colorimetry were measured on cores from all three holes. Measurements were made on APC and XCB cores from Holes U1354A-U1354C to depths of 85.4 $\mathrm{m}$ (Section 317-U1354A-19H-5), $77.2 \mathrm{~m}$ (Section 317-U1354B-15H-5), and $384.2 \mathrm{~m}$ (Section 317U1354C-36X-2). Unless otherwise specified, all depths in this section are reported in m CSF-A.

\section{Gamma ray attenuation bulk density}

GRA bulk density was measured at $2.5 \mathrm{~cm}$ intervals (measurement time $=3 \mathrm{~s}$ ). The raw data range from -0.44 to $2.48 \mathrm{~g} / \mathrm{cm}^{3}$ (Fig. F19). Variations in GRA density may reflect varying sand content in the cores.

A comparison of GRA densitometer data with MAD data from Hole U1354B highlights key similarities with Site U1353 (Fig. F20). In particular, MAD and GRA densitometer results show the same multicore trends, but GRA densitometer bulk density estimates 
are consistently $\sim 2 \%-3 \%$ higher than MAD bulk density estimates. Although this is only slightly above the expected error of the MAD method, such an error should be randomly distributed about the GRA results; thus, a systematic error either in MAD measurements or in GRA densitometer calibration must be present. As discussed in "Physical properties" in the "Site U1353" chapter, the most likely problem is a calibration error with the GRA system.

\section{Magnetic susceptibility}

Magnetic susceptibility (MSL) was measured at 2.5 $\mathrm{cm}$ intervals (measurement time $=2 \mathrm{~s}$ ), and magnetic susceptibility (MSP) was measured at $5 \mathrm{~cm}$ intervals. MSP measurements were made on all sections unless drilling or surface disruption precluded the collection of meaningful results (Fig. F19).

Raw MSL data range from 1.1 to 275.0 instrument units in Holes U1354A and U1354B and from 0.2 to 87.9 instrument units in Hole U1354C (Fig. F19). To help illustrate key trends, the signal was cleaned using a Gaussian low-pass filter (30 passes; Fig. F19).

MSP magnetic susceptibility data at Site U1354 correlate well with data obtained from MSL measurements made on whole-round core sections (Fig. F19). Both MSP and MSL magnetic susceptibility measurements show distinct variations in the uppermost $\sim 170 \mathrm{~m}$ in all three holes, particularly the uppermost $80 \mathrm{~m}$ where core recovery was best.

The general cyclic pattern is very similar to that observed previously, particularly at Site U1351. Three similar intervals between $\sim 12$ and $\sim 76 \mathrm{~m}$ are characterized by a decreasing downhole trend followed by an abrupt change to higher values at 26, 34, and $54 \mathrm{~m}$ (Hole U1354B). The abrupt changes at 34 and $54 \mathrm{~m}$ coincide with two changes in sulfate-methane abundances in Hole U1354A (see "Geochemistry and microbiology"). An interval of high magnetic susceptibility between $\sim 146$ and $\sim 152 \mathrm{~m}$ is not yet understood. The upper end of this interval at $\sim 146 \mathrm{~m}$ might be associated with the Subunit IA/IB boundary (see "Lithostratigraphy"). A slight change in magnetic susceptibility between $\sim 68$ and $70 \mathrm{~m}$ in Hole U1354A and between 64 and $65 \mathrm{~m}$ in Hole U1354B marks the Brunhes/Matuyama boundary and a hiatus that is well documented in paleomagnetic, lithologic, and biostratigraphic records (see "Lithostratigraphy," "Biostratigraphy," and "Paleomagnetism").

The overlapping of Sections 317-U1354A-11H-3 through $11 \mathrm{H}-5$ with $12 \mathrm{H}-1$ through $12 \mathrm{H}-3$ (between 56 and $60 \mathrm{~m}$ ) can be explained by drilling disturbances in the lower part of Core $11 \mathrm{H}$ (Fig. F21). The shell-hash interval in this core, as observed in the conspicuously low values of magnetic susceptibility and NGR for Hole U1354A, was not observed in Hole U1354B.

\section{Natural gamma radiation}

NGR was measured at $10 \mathrm{~cm}$ intervals on all core sections as deep as $240 \mathrm{~m}$ in Hole U1354B (Section $36 \mathrm{X})$. The measured values range from near zero to $>70$ counts per second (cps), with higher values typically associated with muddy lithologies and lower values associated with sands (Fig. F19).

A large-scale sinusoidal pattern of average NGR signal is apparent downhole, with $\sim 70$ cps peaks at $\sim 14$ and $215 \mathrm{~m}$ that are separated first by a gentle decline to $\sim 20 \mathrm{cps}$ at $\sim 75 \mathrm{~m}$, followed by a gentle increase again from $\sim 75$ to $215 \mathrm{~m}$. The change from declining to increasing NGR occurs near the $69.9 \mathrm{~m}$ (Hole $\mathrm{U} 1354 \mathrm{~A}$ ) and $64.75 \mathrm{~m}$ (Hole U1354B) locations of the Brunhes/Matuyama boundary and also coincides with a marked reduction in the abundance and diversity of nannofossil assemblages (see "Biostratigraphy").

The larger scale sinusoidal NGR pattern is modulated by the same shorter, cyclic changes in NGR documented for the upper portions of Sites U1351U1353. Many of these changes probably reflect lithologic changes related to sea level variations at 100 k.y. (back to $0.6 \mathrm{Ma}$ ) and 40 k.y. (earlier) Milankovitch cyclicity. Above the Brunhes/Matuyama boundary, the NGR record (and also the magnetic susceptibility record) reflects two major cycles that probably correspond to marine isotope Stages (MIS) $1-7$, with significant sand units at $22-32$ and 56$61 \mathrm{~m}$ that can be correlated tentatively with MIS Interglacials 5 and 7, respectively. Below the Brunhes/ Matuyama boundary, probable 40 k.y. Milankovitchscale variations in NGR and lithology continue, but no specific correlation can yet be made with the established oxygen isotope record.

\section{$P$-wave velocities}

$P$-wave velocities were recorded continuously in Holes U1354A-U1354C at $2.5 \mathrm{~cm}$ intervals using the PWL. The PWC and PWB were used to measure $P$ wave velocity in Holes U1354B and U1354C (Fig. F22B). $P$-wave measurements yielded good results in the uppermost $217.5 \mathrm{~m}$. Comparably good results were observed only in cores from Site U1353. At both sites, the long records are a result of the absence of the sediment cracking caused by high gas content at Sites U1351 and U1352. With this data set, an excellent positive correlation was found between PWL estimates from both holes, and a good correlation 
was found between PWL, PWC, and PWB estimates in Holes U1354B and U1354C. Nevertheless, PWB Pwave velocities are generally slightly lower than velocities measured with the PWL and PWC.

$P$-wave velocities show little vertical trend and average $\sim 1500-1600 \mathrm{~m} / \mathrm{s}$. One major step was observed at $20-21 \mathrm{~m}$ in Hole U1354A and at $19-20 \mathrm{~m}$ in Hole U1354B. An offset between $\sim 68$ and $70 \mathrm{~m}$ in Hole U1354A and between 64 and $65 \mathrm{~m}$ in Hole U1354B marks a hiatus that was also observed in magnetic susceptibility.

\section{Spectrophotometry and colorimetry}

Spectrophotometric measurements and associated colorimetric calculations were made on section halves at $5 \mathrm{~cm}$ intervals at the same positions as MSP measurements. Color data were recorded as $L^{*}, a^{*}$, and $b^{*}$ variations. Several pronounced changes in color occur at Site U1354, and these are particularly well expressed in the upper part of the site, where core recovery was greatest (Fig. F23). Decreases in L* are typically coeval with decreases in $\mathrm{b}^{*}$ and increases in $\mathrm{a}^{*}$, a pattern also noted at Site U1353. An example occurs in the interval between 20 and $26 \mathrm{~m}$ in Hole U1354B (all sections of Core 7H). This shift between 20 and $26 \mathrm{~m}$ is associated with a decrease in both NGR and magnetic susceptibility (Fig. F23). Lithologically, this interval is associated with a sandy horizon. A sharp excursion to higher $b^{*}$ values occurs at $\sim 50 \mathrm{~m}$ in Hole U1354B, which is also coeval with a decrease in NGR and magnetic susceptibility. A less pronounced and more protracted increase in $\mathrm{L}^{*}$ values is associated with this shift, as well as a shift to lower $\mathrm{a}^{*}$ values. (Fig. F23). This excursion is associated with a marl interval (see "Lithostratigraphy"). The fact that both of these intervals are associated with low NGR and magnetic susceptibility values highlights the utility of using color measurements to help distinguish between the causes of changes in NGR and magnetic susceptibility.

\section{Moisture and density}

MAD sampling of cores on the catwalk, followed by adjacent sampling on the sample table, was carried out in cores from Holes U1354B and U1354C (Cores $1 \mathrm{X}$ through 15X). MAD samples were taken prior to discrete $P$-wave analysis. This approach effectively removed any bias toward more water being in the sample table samples: there was excellent correlation between catwalk and sample table MAD results (Fig. F24). We recommend that future MAD sampling be performed in this manner and that catwalk samples are not required.

In the uppermost $10 \mathrm{~m}$ of Hole U1354B, porosity and void ratio decrease and bulk density increases. There is little change in the following $100 \mathrm{~m}$, below which porosity decreases again (Fig. F25). These observations are consistent with the porosity trends seen at the other three sites. Grain density shows some scatter near the surface, reflecting the variable lithology in Hole U1354B (see "Lithostratigraphy"). These grain densities in the top of Hole U1354B are more variable than those at Sites U1352 and U1353 but are less variable than those at Site U1351, suggesting decreasing variability with distance from the shore.

\section{Sediment strength}

Sediment strength measurements were conducted on working section halves from Holes U1354B and U1354C using automated vane shear (AVS) and fall cone penetrometer (FCP) testing systems (Fig. F26).

A comparison of both measurement methods is shown in the cross-plot in Figure F26C. Shear strength indicates that sediments range from very soft $\left(0-20 \mathrm{kN} / \mathrm{m}^{2}\right)$ to very stiff $\left(150-300 \mathrm{kN} / \mathrm{m}^{2}\right)$. Vane shear and fall cone shear strength correlate well in very soft and soft sediments, but AVS values are about three times lower in firm to very stiff sediments (standard deviation $=22.8 \mathrm{kPa}$ ) than FCP values (standard deviation $=86.0 \mathrm{kN} / \mathrm{m}^{2}$ ). A similar pattern was observed at all other Expedition 317 sites. These findings suggest that the applicability of vane shear in firm to very stiff sediments is limited and that the vane shear test underestimates the strength of stiffer sediments. Overall, vane shear and fall cone strength data from Hole U1354B are positively correlated (Fig. F26). Between 0 and $\sim 250 \mathrm{~m}$, shear strength generally increases, indicating a change from very soft to firm sediments. The lower sediment strength below $\sim 250 \mathrm{~m}$ was also observed in cores from Hole U1353C and might coincide with XCB drilling.

\section{Geochemistry and microbiology Organic geochemistry}

Shipboard organic geochemical studies of cores from Holes U1354A-U1354C included monitoring hydrocarbon gases, carbonate carbon, total carbon (TC), organic carbon, and total nitrogen (TN). The procedures used in these studies are summarized in "Geochemistry and microbiology" in the "Methods" 
chapter. All depths in this section are reported in m CSF-A.

\section{Volatile gases}

All cores recovered from Holes U1354A and U1354C were monitored for the presence of gaseous hydrocarbons using the headspace (HS) gas technique (Table T15). In Hole U1354A, only background amounts (1-3 ppmv) of hydrocarbons were detected, with the exception of the 33-75 m depth interval, where headspace methane increases to a peak of 23 ppmv at $46 \mathrm{~m}$ and then decreases to background levels below $75 \mathrm{~m}$ (Fig. F27). HS samples from sediments with slightly elevated methane also contain trace amounts (0.7-1.3 ppmv) of ethane (Fig. F27).

Small amounts of gas were recovered from air enclosed in the core liner of Cores 317-U1354A-14H and 317-U1354B-14H (Table T16). These samples were reported as core void gas (VAC) samples, but were not from an actual gas void within the core. These samples contain methane (3.0-4.8 ppmv) slightly above background levels; no ethane was detectable.

HS samples from Hole U1354C also contain only background levels of methane to $\sim 200 \mathrm{~m}$, where methane concentrations begin to increase, eventually leveling off in the range of 12,000-22,000 ppmv to the deepest sample in Hole U1354C at $375 \mathrm{~m}$. All samples from Hole U1354C with elevated methane concentrations also contain 2-29 ppmv ethane. $\mathrm{CO}_{1}$ is present in HS samples below $250 \mathrm{~m}$ at concentrations significantly above atmospheric levels (Fig. F27). $\mathrm{C}_{3+}$ hydrocarbons were not detected in samples from Site U1354.

\section{Carbon and elemental analyses}

The results of inorganic carbon (IC), carbonate, TC, total organic carbon by difference $\left(\mathrm{TOC}_{\mathrm{DIFF}}\right), \mathrm{TN}$, and $\mathrm{TOC}_{\mathrm{DIFF}} / \mathrm{TN}$ analyses on selected sediment samples from Site U1354 are given in Table T17. Only 18 sediment samples were analyzed because of time constraints at the end of the expedition. TC, TN, TOC DIFF, and calcium carbonate contents are plotted against burial depth in Figure F28. Calcium carbonate contents range from 1.3 to $52 \mathrm{wt} \%$ in sediments analyzed to burial depths of $81 \mathrm{~m}$ (Fig. F28A). TC (as at Site U1353) has a profile remarkably similar to that of carbonate content, with no trend but with the highest values ( $>5 \mathrm{wt} \%$ ) clustered in the $73-76 \mathrm{~m}$ depth range. TN amounts are very low and range from 0.004 to $0.08 \mathrm{wt} \%$, having no apparent trend with depth (Fig. F28C).

Organic carbon ranges from 0.02 to $1.1 \mathrm{wt} \%$ (Fig. F28D), with the highest value at $50 \mathrm{~m}$. The ratio of
$\mathrm{TOC}_{\mathrm{DIFF}} / \mathrm{TN}$ generally decreases with depth, with the exception of the high-carbonate samples in the 73$76 \mathrm{~m}$ depth interval (Fig. F28E).

\section{Inorganic geochemistry}

A total of 69 interstitial water samples (Tables T18, T19) were collected and analyzed at Site U1354. Hole U1354A, which was dedicated mainly to wholeround sampling for geochemistry, was sampled at an average frequency of one sample per $1.7 \mathrm{~m}$ down to $84 \mathrm{~m}$. Hole U1354C was sampled less frequently (one sample per core, where recovery allowed) from 82 to $319 \mathrm{~m}$. Interstitial water chemistry is plotted versus depth in Figures F29-F34.

\section{Salinity, chloride, sodium, and pH}

Salinities in samples near the seafloor are about normal seawater values of 3.4 and decline to 3.3 over the 17-38 m depth interval (Fig. F29A). From 38 to $150 \mathrm{~m}$, salinity gradually increases to slightly above seawater (3.6) and then fluctuates to lower values at $\sim 210 \mathrm{~m}$ before climbing to 3.8 in the bottom three samples. Chloride (Fig. F29B) and sodium (Fig. F29C) do not parallel salinity measurements, but both increase to $\sim 15 \%$ above seawater values over the 0-84 m depth interval. From 84 to $240 \mathrm{~m}$, chloride and sodium values scatter between 580 and 640 $\mathrm{mM}$ and 520 and $560 \mathrm{mM}$, respectively, and do not significantly vary with depth. Sodium and chloride increase significantly in the bottom two samples in parallel with the increase in salinity (Fig. F29). Measured $\mathrm{pH}$ values scatter between 7.1 and 7.8, with no consistent depth trend (Fig. F29D).

\section{Calcium, magnesium, and strontium}

Calcium and magnesium both decrease below a 0 $3.7 \mathrm{~m}$ chemically homogeneous zone to minima of $5.7 \mathrm{mM}$ at $22 \mathrm{~m}$ for calcium and $30.7 \mathrm{mM}$ at $54 \mathrm{~m}$ for magnesium (Fig. F30A-F30B). Calcium then increases to $13.1 \mathrm{mM}$ and magnesium increases to 41.1 $\mathrm{mM}$ at $178 \mathrm{~m}$. Between $178 \mathrm{~m}$ and the next sampled depth at $205 \mathrm{~m}$, a major discontinuity in the calcium concentration profile is evident, with calcium decreasing by $34 \%$ to $8.6 \mathrm{mM}$ and then rising gradually to $15.6 \mathrm{mM}$ in the deepest sample at $318 \mathrm{~m}$. Magnesium also decreases in the same depth interval, but not as dramatically. The $\mathrm{Mg} / \mathrm{Ca}$ ratio increases from 5.1 in near-surface sediments to 6.3 at the depth of the calcium minimum, decreases to 3.1 at $178 \mathrm{~m}$, increases to 4.3 at $215 \mathrm{~m}$, and then drops gradually to 2.4 at $318 \mathrm{~m}$ (Fig. F30C).

Strontium rapidly increases between 5.1 and $17.6 \mathrm{~m}$ from seawater values to a maximum of $440 \mu \mathrm{M}$ before gradually increasing toward $600 \mu \mathrm{M}$ at $\sim 60 \mathrm{~m}$ 
(Fig. F30D). Thereafter, strontium concentrations vary between 518 and $622 \mu \mathrm{M}$. The $\mathrm{Sr} / \mathrm{Ca}$ ratio increases rapidly from seawater values in near-surface sediments to a maximum of $\sim 0.075$ at $34-41 \mathrm{~m}$ before gradually decreasing again to $\sim 0.046$ at $178 \mathrm{~m}$ (Fig. F30E). The Sr/Ca ratio increases to 0.067 in the calcium minimum zone, before decreasing to 0.034 in the deepest sample.

\section{Alkalinity, sulfate, and phosphate}

Alkalinity is relatively constant over a near-surface $(0-3.7 \mathrm{~m})$ chemically homogeneous zone and then increases somewhat steeply from $3.1 \mathrm{mM}$ at $3.7 \mathrm{~m}$ to $8.8 \mathrm{mM}$ at $12.2 \mathrm{~m}$. Alkalinity fluctuates between 8.7 and $10.3 \mathrm{mM}$ to $50 \mathrm{~m}$ (Fig. F30F) and then slowly decreases to $\sim 2.2 \mathrm{mM}$ at $318 \mathrm{~m}$, with the exception of samples from Sections 317-U1354C-18X-2 (205.20 $\mathrm{m})$ and 19X-2 $(214.70 \mathrm{~m})$, which show elevated alkalinities of 3.8 and $4.2 \mathrm{mM}$, respectively. Sulfate decreases rapidly beneath the chemically homogeneous zone from $28 \mathrm{mM}$ at $3.7 \mathrm{~m}$ to zero at $34.2 \mathrm{~m}$. Sulfate remains at or near zero to $\sim 59 \mathrm{~m}$ and then gradually increases to $16.4 \mathrm{mM}$ at $178 \mathrm{~m}$ (Fig. F31A). Sulfate returns to zero by the next sampled depth at $205 \mathrm{~m}$, which corresponds with the depth of the second increases in methane and alkalinity.

Phosphate increases from $4.7 \mu \mathrm{M}$ at $1.3 \mathrm{~m}$ to 13.8 $\mu \mathrm{M}$ at $9.7 \mathrm{~m}$, remains high to $21 \mathrm{~m}$, and then decreases steadily to $1.4 \mu \mathrm{M}$ at $79 \mathrm{~m}$ (Fig. F31B). Deeper samples have phosphate concentrations $<1.5 \mu \mathrm{M}$ and a generally uniform trend, except that samples at 205.2 and $214.7 \mathrm{~m}$ have slightly higher phosphate than adjacent samples.

\section{Potassium, barium, lithium, silicon, boron, iron, and manganese}

Potassium decreases steadily from $\sim 11 \mathrm{mM}$, slightly above seawater values, to $2.9 \mathrm{mM}$ at $235 \mathrm{~m}$, with a slight perturbation in the samples at 165 and $178 \mathrm{~m}$ (Fig. F32A). Potassium then rises again to $4.7 \mathrm{mM}$ at $318 \mathrm{~m}$. Barium rapidly increases to $2.5 \mu \mathrm{M}$ at $23.6 \mathrm{~m}$ and then varies at $\sim 2.3 \mu \mathrm{M}$ between 23.6 and $57.6 \mathrm{~m}$ (Fig. F32B). Barium increases to $3.0 \mu \mathrm{M}$ at $67.8 \mathrm{~m}$ and then decreases to $1.2 \mu \mathrm{M}$ at $111 \mathrm{~m}$, with a spike to $2.6 \mu \mathrm{M}$ at $97 \mathrm{~m}$. Thereafter, barium remains constant before increasing below $150 \mathrm{~m}$ to a maximum of $7.9 \mu \mathrm{M}$ in the deepest sample at $318 \mathrm{~m}$, and with a spike to $3 \mu \mathrm{M}$ at $165 \mathrm{~m}$.

Lithium initially increases from seawater values in the shallowest sample to $41.1 \mu \mathrm{M}$ at $19.2 \mathrm{~m}$ and then remains relatively constant to $32.6 \mathrm{~m}$ (Fig. F32C). Below $32.6 \mathrm{~m}$, lithium begins to decrease from $41.8 \mu \mathrm{M}$ to a minimum of $19.9 \mu \mathrm{M}$ at $104 \mathrm{~m}$. It then increases with depth, with a perturbation in the trend be- tween 160 and $200 \mathrm{~m}$. The deepest sample contains the maximum concentration of $86.6 \mu \mathrm{M}$.

Silicon concentrations increase from 188 to $595 \mu \mathrm{M}$ in the uppermost $12 \mathrm{~m}$ and then decrease to $\sim 400 \mu \mathrm{M}$ (Fig. F32D). From 17.6 to $100 \mathrm{~m}$, silicon mainly varies between 350 and $550 \mu \mathrm{M}$, with some concentration peaks as high as $664 \mu \mathrm{M}$ (Fig. F32D). From 100 to $165 \mathrm{~m}$, silicon gradually decreases to $221 \mu \mathrm{M}$ and then remains nearly constant to the deepest sample.

Boron concentrations are at seawater values of $\sim 0.4 \mathrm{mM}$ in the shallowest samples and gradually increase in a fairly even fashion to $1.26 \mathrm{mM}$ in the deepest sample (Fig. F33A).

Both iron and manganese concentrations are largely scattered between 9 and $22 \mu \mathrm{M}$ and 3 and $9 \mu \mathrm{M}$, respectively (Fig. F33B-F33C). Iron and manganese tightly co-vary throughout the cored interval at Site U1354. Iron has a significantly high concentration of $27.6 \mu \mathrm{M}$ at $56.2 \mathrm{~m}$, which is not mirrored by the manganese profile (Fig. F33B-F33C). Below $85 \mathrm{~m}$, both iron and manganese have relatively constant values, except that manganese is elevated relative to iron in the three deepest samples (Fig. F33B-F33C).

\section{Preliminary interpretation of diagenesis}

Interstitial water geochemistry in the uppermost $80 \mathrm{~m}$ at Site U1354 is dominated by a zone of complete sulfate depletion from 34 to 60 m (Figs. F34, F35). The boundaries of this zone are characterized by inflections in the magnetic susceptibility data (see Fig. F19). Where sulfate is zero, methane begins to build up. It then decreases to near background concentrations at $60 \mathrm{~m}$, the depth at which sulfate reappears in the cores. The apparent carbon-sulfur stoichiometry of sulfate reduction is significantly different above and below the zone of sulfate depletion (Fig. F35). In the 0-34 $\mathrm{m}$ depth interval above the region of zero sulfate, the ratio of [alkalinity added plus cations $\left(\mathrm{Ca}^{2+}\right.$ and $\mathrm{Mg}^{2+}$ ) removed] to sulfate removed is 1.3:1, consistent with sulfate reduction being fueled by about one-third organic matter oxidation and two-thirds anaerobic methane oxidation. In the $60-178 \mathrm{~m}$ depth interval, the same ratio is $0.98: 1$, indicating that sulfate reduction is driven almost exclusively by anaerobic methane oxidation (Fig. F35). The very low phosphate throughout the deeper zone and the somewhat higher phosphate in the shallower sulfate reduction zone is consistent with small quantities of phosphate being generated by organic-matter oxidation in the $0-34 \mathrm{~m}$ depth interval. The methane oxidation occurring in the deeper sulfate reduction zone generates no phosphate ions. However, below $84 \mathrm{~m}$ in Hole U1354C, the slopes of the sulfate, alkalinity, calcium, and 
magnesium depth profiles all change slightly, and the exact relationship developed in Hole U1354A may not apply for the deeper interval in Hole U1354C.

A hiatus is present at $\sim 75 \mathrm{~m}$, marked by a change in sedimentation rate from $210 \mathrm{~m} / \mathrm{m}$.y. above to 93 $\mathrm{m} / \mathrm{m}$.y. below, which is followed by a further decrease to $45 \mathrm{~m} / \mathrm{m}$.y. below another hiatus at $\sim 128$ $190 \mathrm{~m}$. Below $190 \mathrm{~m}$, the sedimentation rate increases dramatically to $400 \mathrm{~m} / \mathrm{m}$.y. to the bottom of the hole (see Fig. F29 in the "Expedition 317 summary" chapter). The change in sedimentation rate below $190 \mathrm{~m}$ is coincidental with the second appearance of methane at Site U1354 at $200 \mathrm{~m}$. Apparently, sediments within the 74-190 m depth interval were deposited at a rate slow enough to permit continuous replenishment of dissolved sulfate by diffusion from overlying seawater, thereby preventing methanogenesis. A review of methane occurrence at Deep Sea Drilling Project (DSDP)/ODP/ IODP sites indicates that $\sim 40-50 \mathrm{~m} / \mathrm{m}$.y. is the minimum sedimentation rate required for sulfate depletion and methanogenesis to occur.

One notable aspect of the shallow pore water chemistry profiles at Site U1354 is the lack of a low-salinity zone like that seen at $\sim 50 \mathrm{~m}$ at the more nearshore Site U1353. This may help clarify the origin of this low-salinity zone. The water depth at Site U1353 is $85 \mathrm{~m}$, compared with $110 \mathrm{~m}$ at Site U1354. Global sea level was $\sim 125 \mathrm{~m}$ below today's sea level at the Last Glacial Maximum 20,000 years ago (Fairbanks, 1989), so both site locations may have experienced periods of complete emergence. Therefore, the lack of less saline water at Site U1354 and the presence of less saline water at Site U1353 is more likely explained by the modern intrusion of meteoric water from land than by the historic remains of freshwater emplaced when the shelf was emergent.

Other changes in interstitial water chemistry at Site U1354 are possibly related to carbonate diagenesis and contributions from deeper basinal brines. The main decreases in dissolved calcium and magnesium occur within the depth intervals characterized by sulfate reduction, methanogenesis, and anaerobic methane oxidation. These processes are commonly associated with precipitation of authigenic carbonates with distinct carbon isotopic compositions. The increases in sodium and chloride from 0 to $60 \mathrm{~m}$, which are possibly related to an influx of saline fluid, may also account for some of the other changes seen at Site U1354, such as increases in barium, lithium, and boron with depth.

Alternative sources of lithium could relate to ion-exchange or desorption reactions on authigenic clays and the transformation of biogenic opal to opal-A. The increase in lithium does not correspond to the increase in silica. This relationship was also observed at the other sites and may suggest a rather subtle influence of biogenic opal and that the major source of lithium is the diagenesis of lithium-rich clay minerals. The boron increase with depth may also be related to the diagenetic opal transition and microbial degradation of organic matter. The rapid barium increase in the sulfate reduction zone may reflect barite dissolution that resulted from enhanced barite solubility.

\section{Microbiology}

No microbiological experiments were carried out and no microbiological samples were recovered at Site U1354.

\section{Heat flow Geothermal gradient}

Two temperature measurements were made using the SET tool in Cores 317-U1354C-14X and 16X. The results of these measurements were poor because the conductive cooling time after sediment penetration was too short (Table T20; Fig. F36), possibly as a result of tool movement within the sediment because of ship heave and/or penetration of loose, caved sediments at the bottom of the hole. Accordingly, it was not possible to determine geothermal gradient and heat flow.

\section{Thermal conductivity}

Thermal conductivity was measured in whole-round core sections from Holes U1354A-U1354C using the full-space needle probe method. Cores retrieved from broken liners were not measured. Measurement frequency was usually more than once per core (specifically, once every two sections above $50 \mathrm{~m}$ CSF-A; unless otherwise noted, all depths in this section are reported in $\mathrm{m}$ CSF-A) and once every section below $50 \mathrm{~m}$, with five measuring cycles at each point. This includes 35 points in Hole U1354A $(0.7-84.8 \mathrm{~m}), 25$ points in Hole U1354B (0.7-75.9 $\mathrm{m})$, and 43 points in Hole U1354C $(67.2-374.8 \mathrm{~m})$ (Table T21). The middle of each section was chosen as the measurement point unless a void or crack was observed (see "Heat flow" in the "Methods" chapter). Probe V10701 was used, and heating power was kept to $\sim 3 \mathrm{~W}$ for the full-space method.

After quality control (see "Heat flow" in the "Methods" chapter), good results were obtained for 17 points in Hole U1354A, 14 points in Hole U1354B, 
and 23 points in Hole U1354C, covering depth intervals of $0.7-82.6,3.2-75.9$, and 70.2-336.6 m, respectively (Table T21). Although the number of measuring cycles was increased to five based on experience gained from Site U1352, many measurements were still discarded because of poor contact caused by loose sediments.

Thermal conductivity measurements at Site U1354 range from 1.183 to $1.873 \mathrm{~W} /(\mathrm{m} \cdot \mathrm{K})$ (average $=1.409$ $\mathrm{W} /[\mathrm{m} \cdot \mathrm{K}]$ ) (Table T21). These values are slightly higher than those from slope Site U1352 for the equivalent depth interval (to $\sim 375 \mathrm{~m}$ ). For the uppermost $130 \mathrm{~m}$, thermal conductivity values are also higher at Site U1354 than in the same interval at nearby ODP Site 1119 (Shipboard Scientific Party, 1999). The high conductivities at Site U1354 may be due to high concentrations of quartz (6.5-12.5 $\mathrm{W} /[\mathrm{m} \cdot \mathrm{K}])$ in fine-grained sediment, including the clay-sized fraction (see "Lithostratigraphy"), and/ or carbonate cementation $(0.5-4.4 \mathrm{~W} /[\mathrm{m} \cdot \mathrm{K}])$.

Thermal conductivity versus depth data from Holes U1354A and U1354B are consistent (Fig. F37A). In addition, results from Hole U1354C could be projected to those from the upper portions of Holes U1354A and U1354B. Thermal conductivity seems to be constant (or very subtly increasing) with depth, except for peaks at $22-30 \mathrm{~m}$. A similarly constant profile was observed at slope Site U1352. Peaks of $>1.700 \mathrm{~W} /(\mathrm{m} \cdot \mathrm{K})$ come from very fine to fine sand layers, which do not occur in intervals with low porosity or high bulk density. However, thermal conductivity in general correlates negatively with porosity and positively with bulk density, as expected (Fig. F37B-F37C). This may indicate that the sand layers yielding high thermal conductivity values consist mainly of high thermal conductivity material such as quartz. There is no distinguishable correlation between thermal conductivity and lithology at this site.

\section{Downhole logging}

\section{Operations}

Preparations for downhole logging of Hole U1354C began after APC/XCB coring to a total depth of 384.2 $\mathrm{m}$ DSF ( 509 m DRF) was completed at $1800 \mathrm{~h}$ on 1 January 2010 (all times are ship local time, UTC + $13 \mathrm{~h}$ ). In preparation for logging operations, the hole was swept and circulated with $50 \mathrm{bbl}$ of high-viscosity mud and displaced with $320 \mathrm{bbl}$ of heavy mud $(\sim 10.5 \mathrm{ppg})$. The bit was raised to the logging depth of $231 \mathrm{~m}$ DRF (106 m DSF). Because of the potential for unstable hole conditions, our previous experience logging shelf Sites U1351 and U1353, and time constraints at the end of the expedition, logging was limited to a single tool run without radioactive sources. A modified tool string ("sonic combo"), which consisted of the HNGS, the DSI, the General Purpose Inclinometry Tool (GPIT), and the DIT, was rigged up by $0135 \mathrm{~h}$ on 2 January and run into the hole $(\mathrm{RIH})$ at a speed of $2000 \mathrm{ft} / \mathrm{h}$. While the tool string was being lowered, data were recorded from the seafloor to the total depth of $505 \mathrm{~m} \mathrm{WRF}$. The first logging pass was started at total depth at $0245 \mathrm{~h}$ at a speed of $900 \mathrm{ft} / \mathrm{h}$ and stopped at $440 \mathrm{~m} \mathrm{WRF}$, at which point the tool string was again RIH to total depth for a full pass. The main pass began at $0308 \mathrm{~h}$ from total depth at a speed of $900 \mathrm{ft} / \mathrm{h}$ and was completed at $0500 \mathrm{~h}$ when the seafloor was identified in the gamma ray $\log$ at $122 \mathrm{~m}$ WRF. The tool string was brought back to the surface and rigged down completely by $0607 \mathrm{~h}$. By $0625 \mathrm{~h}$, the rig floor was clear of all logging equipment and ready for the cementing protocol in Hole U1354C that concluded drilling operations for Expedition 317.

\section{Data quality}

Figures F38, F39, and F40 summarize the main logging data recorded in Hole U1354C. These data were converted from original field records to depth below seafloor and processed to match depths between different logging runs. The resulting depth scale is wireline log matched depth below seafloor (WMSF; see "Downhole logging" in the "Methods" chapter).

Because the DSI requires borehole centralization to properly measure sonic velocities in the formation, an eccentralizing caliper was not included in the tool string so that the quality of the acoustic logs and the smooth motion of the tool string would not be adversely affected. Without a caliper, the first indicator of the quality of the data is the correlation between the different measurements. If any lows in the gamma ray log were due to hole enlargement, the resistivity and velocity logs should also display lower values or remain unchanged because they are least affected by borehole irregularities. Instead, the significant increases in resistivity and velocity associated with the gamma ray excursions (Figs. F38, F39) show that these intervals are likely consolidated sand-rich layers and that the change in gamma ray is representative of true changes in lithology. A comparison with the logs recorded at the other shelf sites (U1351 and U1353) also shows that the trends and changes in the gamma ray logs can be visually correlated across the shelf (see Fig. F25 in the "Expedition 317 summary" chapter), indicating the good quality of the logs recorded in Hole U1354C. Such correlations between sites will be fully characterized postcruise. 
The gamma ray logs agree reasonably well with the NGR track data measured on cores from Hole U1354C (Fig. F38), validating the overall gamma ray $\log$ trend. However, poor core recovery in intervals with significant gamma ray variability, particularly in the sand-rich intervals, makes it difficult to precisely match log and core measurements.

The quality of some of the logging data sets can also be evaluated by internal consistency. The agreement between the deep- and medium-penetration resistivity curves is an indication that the borehole was not anomalously large or irregular (Fig. F38). The clear arrivals in acoustic logging waveforms and the high coherence indicated by distinct red areas in the $V_{P}$ and $V_{S}$ tracks in Figure F39 show that the DSI was able to measure reliable $V_{\mathrm{p}}$ and $V_{\mathrm{S}}$ values. Additional postcruise processing will refine these profiles and characterize some of the high-coherence events that were not labeled automatically at the time of acquisition. Finally, the comparison in Figure F41 between the data recorded during the downlog and the uplog shows that all measurements repeat very well between the two passes. The notable discrepancies in the $V_{\mathrm{P}}$ and $V_{\mathrm{S}} \operatorname{logs}$ are related to the failure of the automatic processing to identify the correct arrivals and will likely be reduced by postcruise processing. A depth offset in the resistivity curves between $\sim 150$ and $130 \mathrm{~m}$ WMSF is the result of variations in wireline tension and cable stretch when the top of the tool string entered the drill pipe.

\section{Porosity and density estimation from the resistivity log}

In order to provide a measure of porosity and density from the logs without nuclear sources, we used Archie's (1942) relationship to calculate porosity from the phasor deep induction log (IDPH), which is the log least affected by borehole conditions (Schlumberger, 1989) and combined it with MAD grain density data to derive a density profile. Archie (1942) established an empirical relationship between porosity $(\phi)$, formation resistivity $(R)$, and pore water resistivity $\left(R_{\mathrm{w}}\right)$ in sandy formations:

$$
\phi=\left(a R_{\mathrm{w}} / R\right)^{1 / m},
$$

where $m$ and $a$ are two empirical parameters often called cementation and tortuosity (or Archie) coefficients, respectively. The resistivity of seawater $\left(R_{\mathrm{w}}\right)$ was calculated as a function of temperature and salinity, as described by Fofonoff (1985). Pore water salinity was assumed to be $35.5 \mathrm{ppt}$ (or $3.55 \%$; see "Geochemistry and microbiology"), and temperature was assumed to follow a local linear gradient of $40^{\circ} \mathrm{C} / \mathrm{km}$, as suggested by in situ measurements at
Site U1352 (see "Heat flow" in the "Site U1352" chapter) and in the Clipper-1 well (Shell BP Todd, 1984). The most realistic value for the cementation coefficient is $a=1$ because this gives a resistivity equal to formation water resistivity when porosity is $100 \%$. A value of $m=1.9$ was chosen iteratively to provide the best baseline match with MAD porosity data. Although Archie's relationship was originally defined for sand-rich formations, Jarrard et al. (1989) showed that the effect of clay minerals is moderate, and the relationship is commonly used to estimate porosity in clay-rich formations with poor borehole conditions (Collett, 1998; Jarrard et al., 1989). The resulting porosity log is shown in Figure F38, where it compares well with MAD porosity data. Using MAD grain density, we used this resistivity-derived porosity to calculate a new density curve, which is in good agreement with core measurements (Fig. F38).

\section{Logging stratigraphy}

The combined analysis of gamma ray, resistivity, and velocity logs can be used to identify logging units defined by characteristic trends. In addition, the proximity of Site U1354 to Site U1353 and the similarities between the logs recorded at these two sites reflect stratigraphic continuity across the shelf, allowing for the definition of a common logging stratigraphy between the two sites. The two following logging units were identified in Hole U1354C.

Logging Unit 1 (110-285 m WMSF), similar to logging Unit 1 in Hole U1353C, is characterized by an increasing trend in gamma ray from the top of the unit to $\sim 185 \mathrm{~m}$ WMSF, followed by a generally decreasing trend to the base of the unit. These trends are interrupted by intervals of low gamma ray and high resistivity and velocity that are interpreted as sandy intervals, most of which coincide with intervals of low core recovery and the occurrence of sand in the recovered material. In Figure F39, the two most prominent intervals with very high velocity values (185-195 and 220-230 m WMSF) have the same character as two analogous intervals in Hole U1353C (178-185 and 202-208 m WMSF; see "Downhole logging" in the "Site U1353" chapter) and coincide with two seismic unconformities across these two sites (see "Log-seismic correlation").

Logging Unit 2 (285-384 m WMSF) is characterized by slightly decreasing trends with depth in gamma ray and resistivity, with only limited variability, and increasing velocity along a likely compacting trend (Figs. F38, F39). As at Site U1353, this unit is also characterized by very low core recovery associated with the predominance of muddy sands and sandy mud in the recovered intervals (see "Lithostratigraphy"). 


\section{Log-seismic correlation}

A depth-traveltime relationship can be determined from sonic logs and used to correlate features in the logs, recorded in the depth domain, with features in seismic stratigraphy, recorded in the time domain. A synthetic seismogram was constructed for Hole U1354C from the sonic log and the density curve calculated from the resistivity log using Archie's relationship. Figure F42 shows relatively good agreement between the synthetic waveform and reflections in the seismic line closest to Site U1354. High variability in the logs in logging Unit 1 corresponds to an interval of strong seismic reflections between $\sim 0.27$ and $\sim 0.43 \mathrm{~s}$ two-way traveltime. In particular, seismic sequence boundaries U10-U13, interpreted from seismic data (see "Seismic stratigraphy" in the "Expedition 317 summary" chapter), are well resolved in the synthetic seismogram and correspond to distinct features in sonic, calculated density, and gamma ray logs. U9 is somewhat deeper in the seismic section in logging Unit 2, where low variability in the logs results in fewer distinctive waveforms in the synthetic seismogram. U12, U11, and U10 all have similar log characteristics, as at Site U1353, and are located at abrupt transitions from high gamma ray, lower density, and low velocity below to low gamma ray, higher density, and very high velocity above. Although core recovery through these highamplitude features is poor in Hole U1354C, at Site U1353 these boundaries correspond to lithologic changes from dominantly muddy sediments below to sand-, shell-, and gravel-dominated sediments above (see "Lithostratigraphy" in the "Site U1353" chapter). As at Site U1353, U13 is less prominent in both the synthetic seismogram and the seismic stratigraphy than the deeper boundaries, but at Site U1354 it has the same polarity as U10-U12. The difference in polarity between sites could indicate a change in the character of the boundary itself but may also simply be the result of trying to resolve a surface that is thinner than the resolution of the seismic data. Additional postcruise research will refine these correlations by reprocessing the sonic logs and providing more detailed synthesis of core-log correlations at this site.

\section{Stratigraphic correlation}

Holes U1354A, U1354B, and U1354C were drilled $\sim 20 \mathrm{~m}$ from each other, with Hole U1354A being dedicated to whole-round sampling for geochemical analyses. The drilling of three holes at Site U1354 provides an opportunity for stratigraphic correlation and possible construction of a spliced stratigraphic record with a common core composite depth below seafloor (CCSF) depth scale (see "Stratigraphic correlation" in the "Methods" chapter). Magnetic susceptibility (MSL) and NGR data were used to facilitate the correlation of cores at Site U1354. L* reflectance values and GRA bulk density measurements were also used to cross-check the validity of depth adjustments. A number of key features in the analyzed data are shared by all holes, allowing correlative ties to be made (Fig. F43). The depths of these features (expressed in $\mathrm{m}$ CSF-A) are often different between the holes and require depth shifts of individual and/or multiple cores by as much as $2.18 \mathrm{~m}$. This demonstrates that the stratigraphic record for all holes is characterized by localized differences in sedimentation history, as was also found at Sites U1352 and U1353. Because Site U1354 was drilled on the continental shelf, this observation fits with the interpretation that the sedimentation and/ or postsedimentation history of this environment was extremely dynamic.

The correlation presented here suggests that Hole $\mathrm{U} 1354 \mathrm{~B}$ is incomplete relative to Hole U1354A, and depth shifts of cores from Hole U1354B are hence necessary to align tie points between each hole. The correlated holes with depth shifts are plotted in Figure F43, and depth adjustments made to cores are provided in Table T22. A key correlative feature of Holes U1354A and U1354B is the geomagnetic polarity reversal interpreted to include the Brunhes/Matuyama boundary, which occurs at $~ 71.3 \mathrm{~m}$ CCSF (see "Paleomagnetism"). This reversal and its associated lithologic boundary have a distinctive expression in the NGR and MSL data, allowing the event to be unambiguously correlated between the two holes (Fig. F43). Cores from Hole U1354C are below the depth of the Brunhes/Matuyama boundary based on the correlation presented here, and this inference is supported by paleomagnetic polarity data. Below the paleomagnetic reversal, correlation between Holes $\mathrm{U} 1354 \mathrm{~A}, \mathrm{U} 1354 \mathrm{~B}$, and $\mathrm{U} 1354 \mathrm{C}$ is complicated by artifacts in the physical property records arising from drilling disturbance such as shell-hash cave-in. Care, therefore, was taken that these artifacts were not used in correlation. One tie point at $82 \mathrm{~m}$ CCSF was identified in Holes U1354B and U1354C after these artifacts were taken into account.

The presence of drilling disturbance in all holes hindered the creation of a spliced composite record for Site U1354 that includes only the parts of each hole deemed to be best representative of a given depth interval. Indeed, the exclusion of clear artifacts from a spliced record could not be avoided, and only limited increased stratigraphic coverage can be gained by splicing. Furthermore, the fact that Hole U1354B 
is likely incomplete relative to Hole U1354A is problematic for creating a spliced record because the record of Hole U1354A is itself incomplete because of extensive whole-round sampling.

\section{References}

Archie, G.E., 1942. The electrical resistivity $\log$ as an aid in determining some reservoir characteristics. J. Pet. Technol., 5:1-8.

Browne, G.H., and Naish, T.R., 2003. Facies development and sequence architecture of a late Quaternary fluvialmarine transition, Canterbury Plains and shelf, New Zealand: implications for forced regressive deposits. Sediment. Geol., 158(1-2):57-86. doi:10.1016/S00370738(02)00258-0

Collett, T.S., 1998. Well log evaluation of gas hydrate saturations. Trans. SPWLA Annu. Logging Symp., 39:1998MM.

Fairbanks, R.G., 1989. A 17,000-year glacio-eustatic sea level record: influence of glacial melting rates on the Younger Dryas event and deep-ocean circulation. Nature (London, U. K.), 342(6250):637-642. doi:10.1038/ 342637a0

Fofonoff, N.P., 1985. Physical properties of seawater: a new salinity scale and equation of state for seawater. J. Geophys. Res., [Oceans], 90(C2):3332-3342. doi:10.1029/ JC090iC02p03332

Hayward, B.W., 2001. Global deep-sea extinctions during the Pleistocene ice ages. Geology, 29(7):599-602.

doi:10.1130/00917613(2001)029<0599:GDSEDT>2.0.CO;2

Hornibrook, N. de B., Brazier, R.C., and Strong, C.P., 1989. Manual of New Zealand Permian to Pleistocene foraminiferal biostratigraphy. Paleontol. Bull., 56.
Jarrard, R.D., Dadey, K.A., and Busch, W.H., 1989. Velocity and density of sediments of Eirik Ridge, Labrador Sea: control by porosity and mineralogy. In Srivastava, S.P., Arthur, M.A., Clement, B., et al., Proc. ODP, Sci. Results, 105: College Station, TX (Ocean Drilling Program), 811835. doi:10.2973/odp.proc.sr.105.146.1989

Kameo, K., and Bralower, T.J., 2000. Neogene calcareous nannofossil biostratigraphy of Sites 998, 999, and 1000, Caribbean Sea. In Leckie, R.M., Sigurdsson, H., Acton, G.D., and Draper, G. (Eds.), Proc. ODP, Sci. Results, 165: College Station, TX (Ocean Drilling Program), 3-17. doi:10.2973/odp.proc.sr.165.012.2000

Lu, H., and Fulthorpe, C.S., 2004. Controls on sequence stratigraphy of a middle Miocene-Holocene, currentswept, passive margin: offshore Canterbury Basin, New Zealand. Geol. Soc. Am. Bull., 116(11):1345-1366. doi:10.1130/B2525401.1

Schlumberger, 1989. Log Interpretation Principles/Applications: Houston (Schlumberger Educ. Serv.), SMP-7017.

Shell BP Todd, 1984. Drilling completion report, Clipper-1. Offshore Canterbury, South Island, New Zealand. PPL38202. Min. Econ. Dev. N. Z. Pet. Rep., PR1036. https://data.crownminerals.govt.nz/MEDGUEST/ system/mainframe.asp

Shipboard Scientific Party, 1999. Site 1119: drift accretion on Canterbury Slope. In Carter, R.M., McCave, I.N., Richter, C., Carter, L., et al., Proc. ODP, Init. Repts., 181: College Station, TX (Ocean Drilling Program), 1-112. doi:10.2973/odp.proc.ir.181.103.2000

Publication: 4 January 2011

MS 317-106 
Figure F1. A. Dip Profile EW00-01-66 showing Site U1354. B. Crossing strike Profile EW00-01-07A. Red = actual penetration, yellow = proposed penetration. $\mathrm{CDP}=$ common depth point. $\mathrm{MP}=$ Marshall Paraconformity.

A

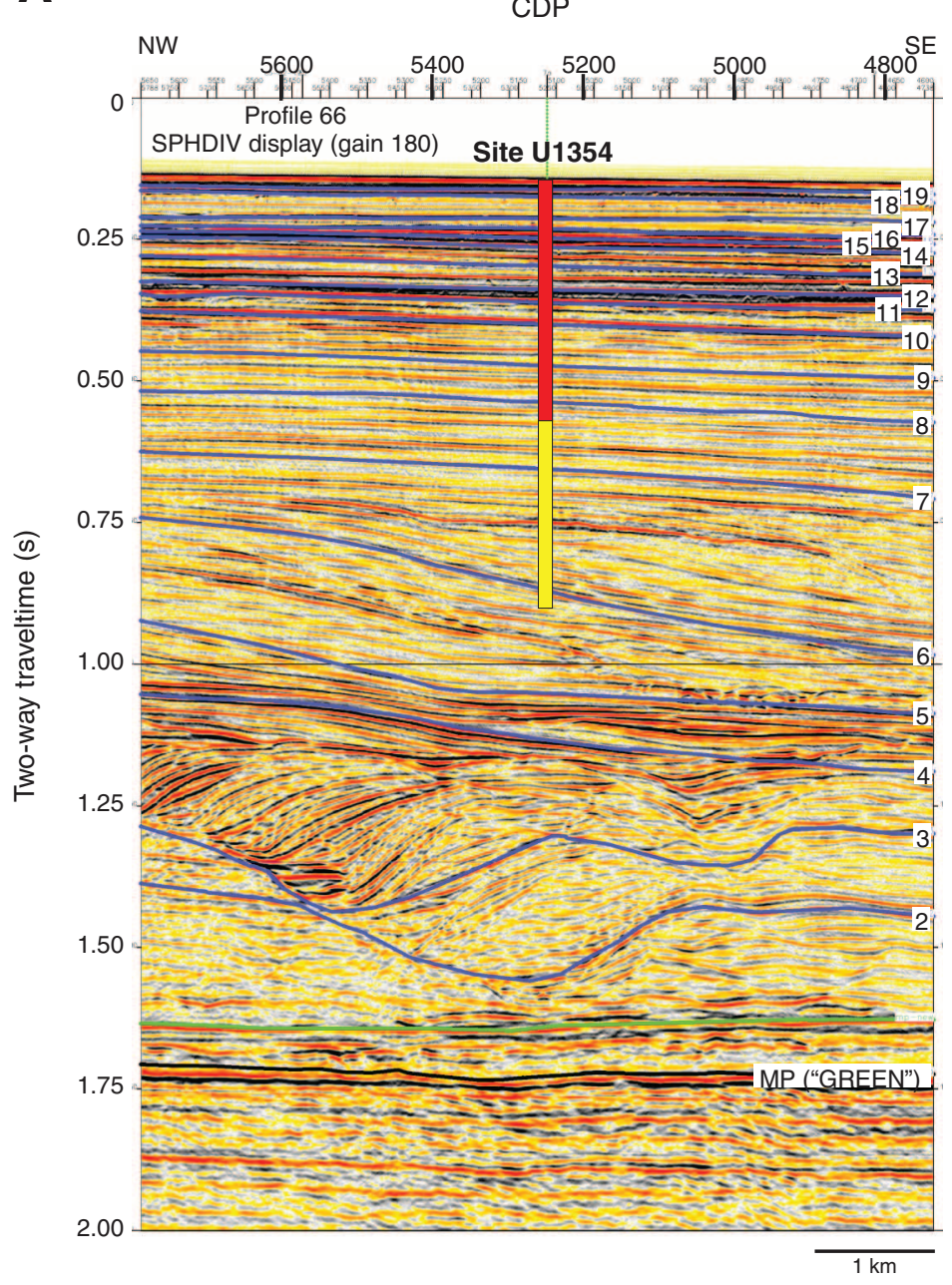

B

CDP

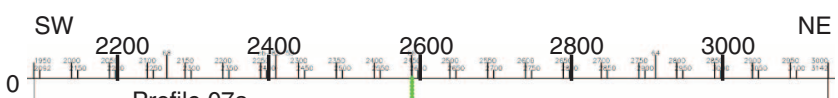
Profile $07 a$

SPHDIV display (gain 180) Site U1354

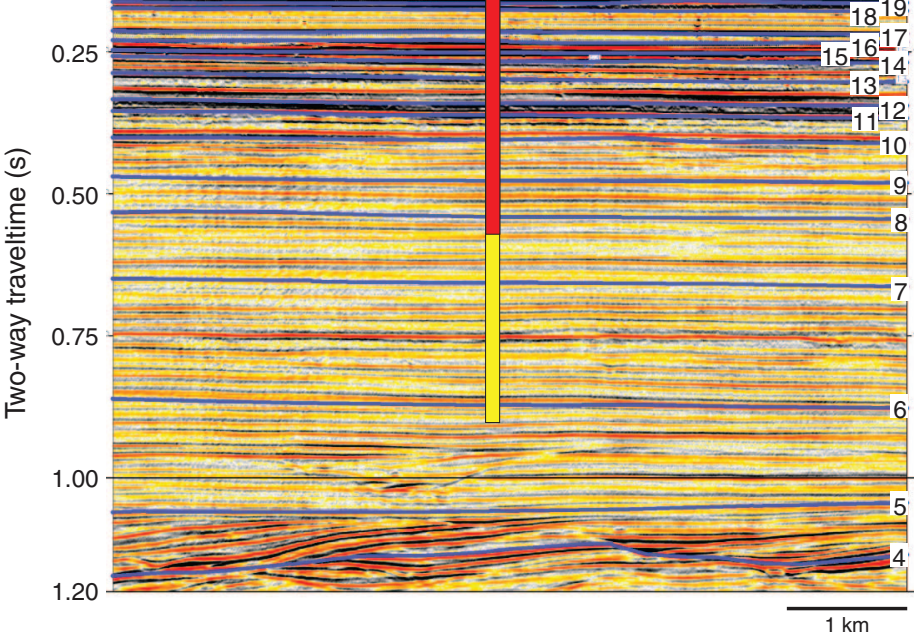


Figure F2. Drilled and proposed Expedition 317 sites, together with EW00-01 high-resolution (frequencies up to $300 \mathrm{~Hz}$ ) MCS grid (thick straight lines), low-resolution CB-82 commercial MCS grid (thin straight lines), exploration wells Clipper and Resolution, and Ocean Drilling Program (ODP) Site 1119. The EW00-01 survey was designed to provide improved vertical resolution ( $\sim 5 \mathrm{~m}$ in the upper $1 \mathrm{~s})$ to enhance our ability to define highfrequency sedimentary sequences. Also shown is the distribution of seismically resolvable sediment drifts D1D11, along with D8 and D9 subdrifts. Blue curved lines = crests of drift mounds, dashed blue lines = drifts identified on CB-82 profiles. Dip Profiles EW00-01-66, EW00-01-60, EW00-01-01, EW00-01-07a, and CB-82-25 are also labeled.

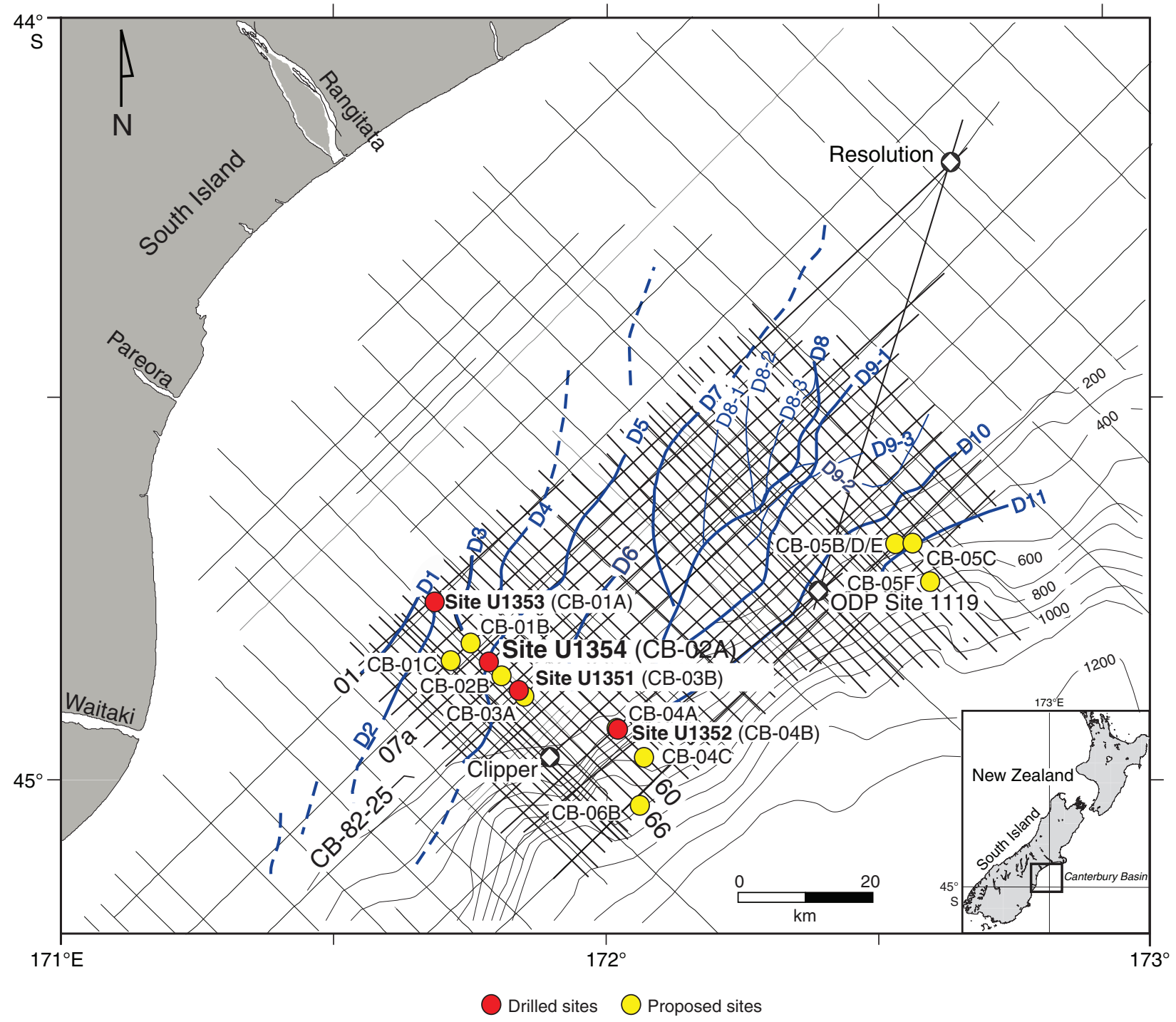


Figure F3. Summary of core recovery, lithology, lithologic units, unit descriptions, physical property data, and gamma ray data from downhole logging, Site U1354. NGR = natural gamma radiation. Downhole logging data are plotted on the WMSF depth scale. A. Hole U1354B. (Continued on next page.)

A

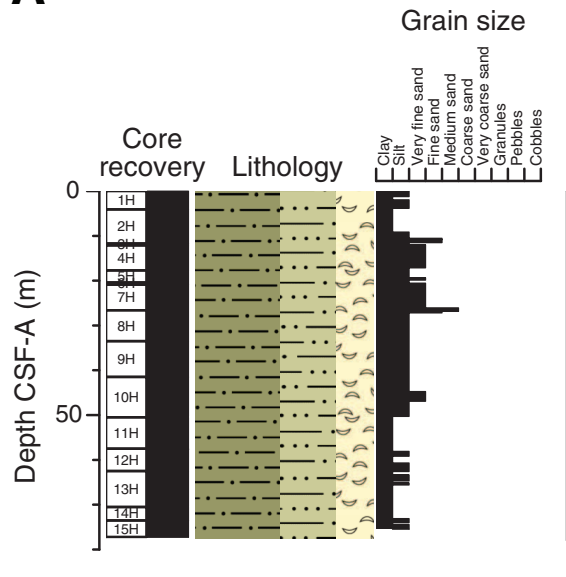

Hole U1354B

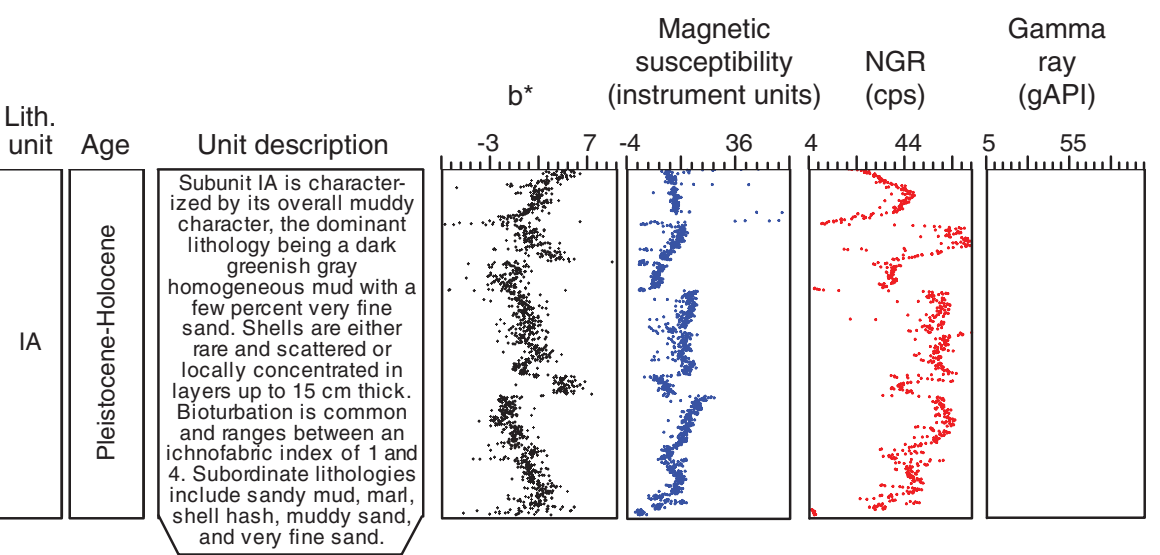


Figure F3 (continued). B. Hole U1354C.

B

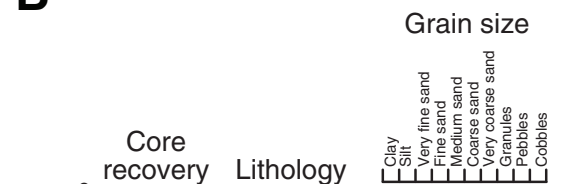

Hole U1354C

Lith.

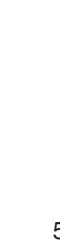

recovery Lithology

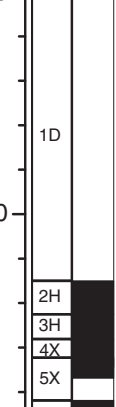

$100-$
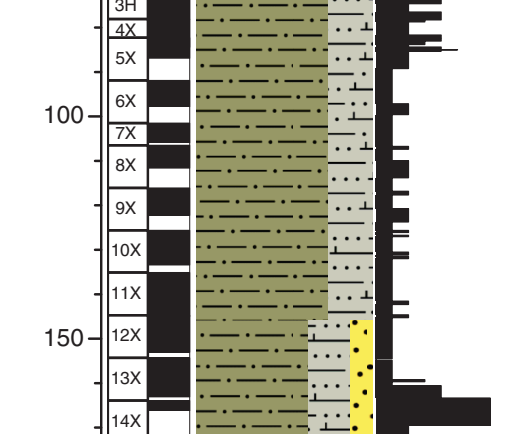

(2)

IA

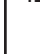

$B$

-...-.

$-\frac{1}{\cdots}$

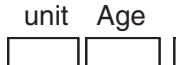

Unit description

Subunit IA is characterized by its overall muddy character, he dominant
lithology being a dark greenish gray

homogeneous mud with a

few percent very fine

sand. Shells are either

rare and scattered or

locally concentrated in

layers up to $15 \mathrm{~cm}$ thick.

Bioturbation is common

and ranges between an

ichnofabric index of 1 and

5. Subordinate lithologies

include sandy mud, marl,

shell hash, muddy sand.

京

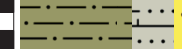

$=\frac{-1 \cdot \cdots}{-\cdot \cdots}$

-

250

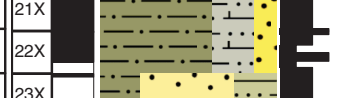

$250-$

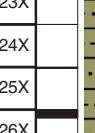

$\because \cdot \frac{\cdots}{\cdots}$
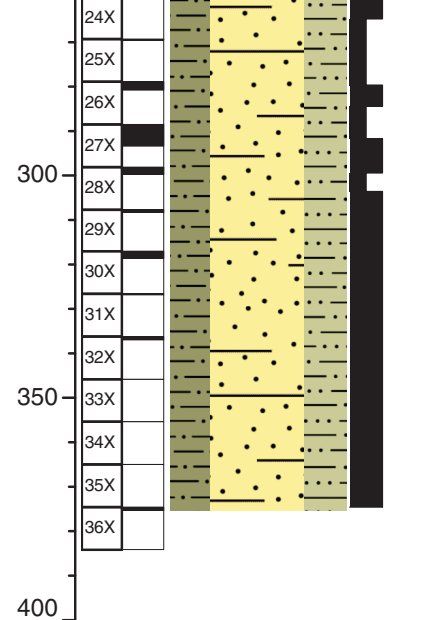

Subunit IB is dominated by mud also, with rare to common shells and subordinate sandy mud, muddy sand, sand, clay,

marl, and marlstone.

Subunits IA and IB are differentiated on the basis that Subunit IA includes gray sands, whereas Subunit IB does not. In addition, Subunit IB contains sandy mart and sandy marlstone.

he dominant lithology of Unit II consists of very dark and dark green

micaceous, very fine

sandy mud and mud, typically with shells. Both types of sediment have variable degrees of ioturbation ranging from absent to heavy

(ichnofabric index of 1-4). Muddy very fine sand whells occurs as minor lithology.
Magnetic

susceptibility

$\mathrm{b}^{*} \quad$ (instrument units)

(cps)

Gamma

(gAPI)

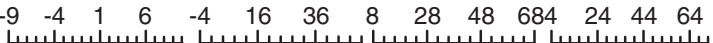

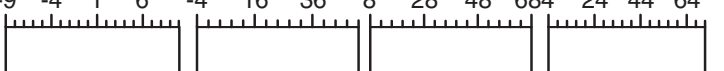


Figure F4. Core recovery and lithology shown as a proportion of the recovered interval (lithology [\%] $\times$ recovery [\%]/100) in Hole U1354B. Depth scale in CSF-A (m) is variable, but for graphical purposes each core is depicted by an equally thick horizontal bar.

Hole U1354B

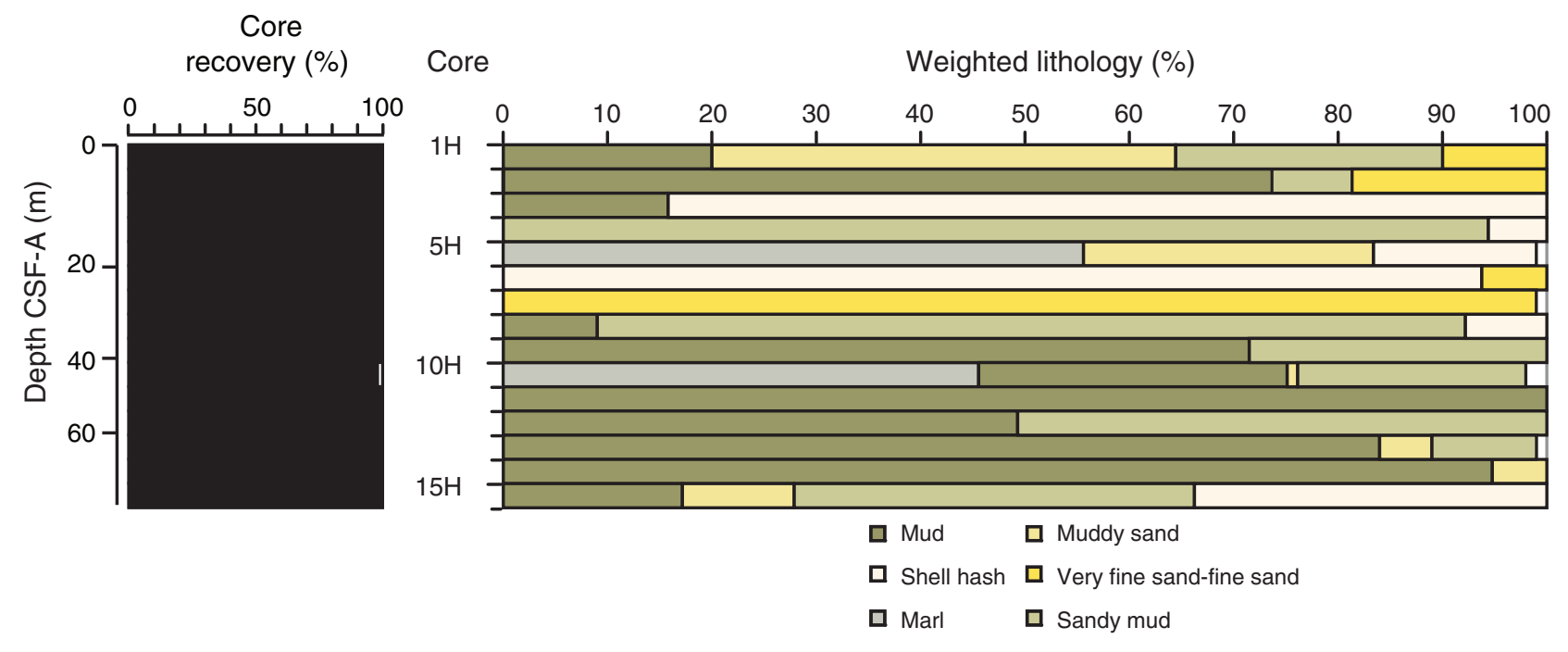


Figure F5. Core recovery and lithology shown as a proportion of the recovered interval (lithology [\%] $\times$ recovery [\%]/100) in Hole U1354C. Depth scale in CSF-A (m) is variable, but for graphical purposes each core is depicted by an equally thick horizontal bar.

Hole U1354C

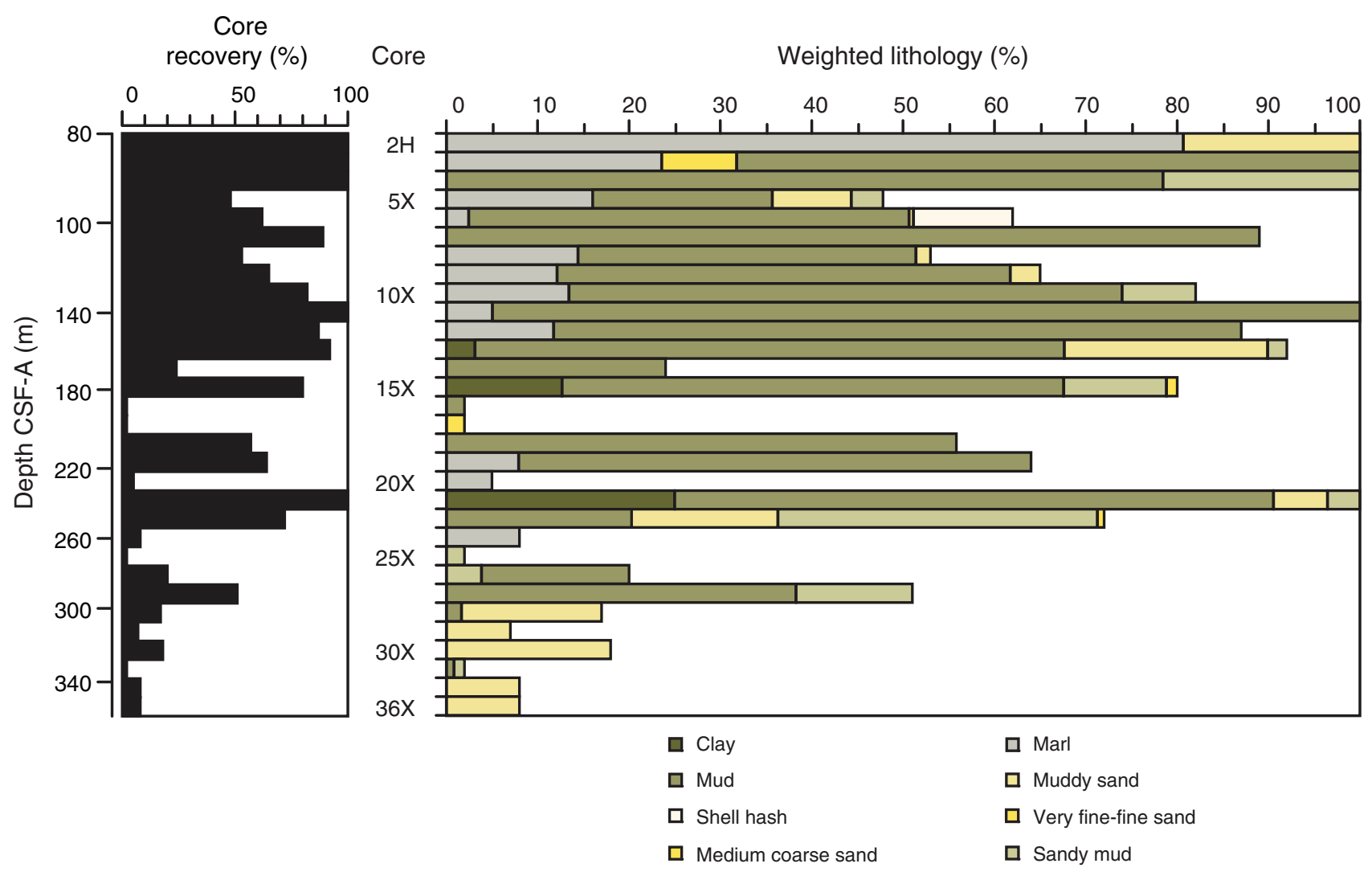


Figure F6. Tentative lithostratigraphic correlation between Holes U1354A and U1354B. Correlative lithostratigraphic horizons and surfaces are connected with gray lines. Geochemical and interstitial water sampling horizons are shown for Hole U1354A.

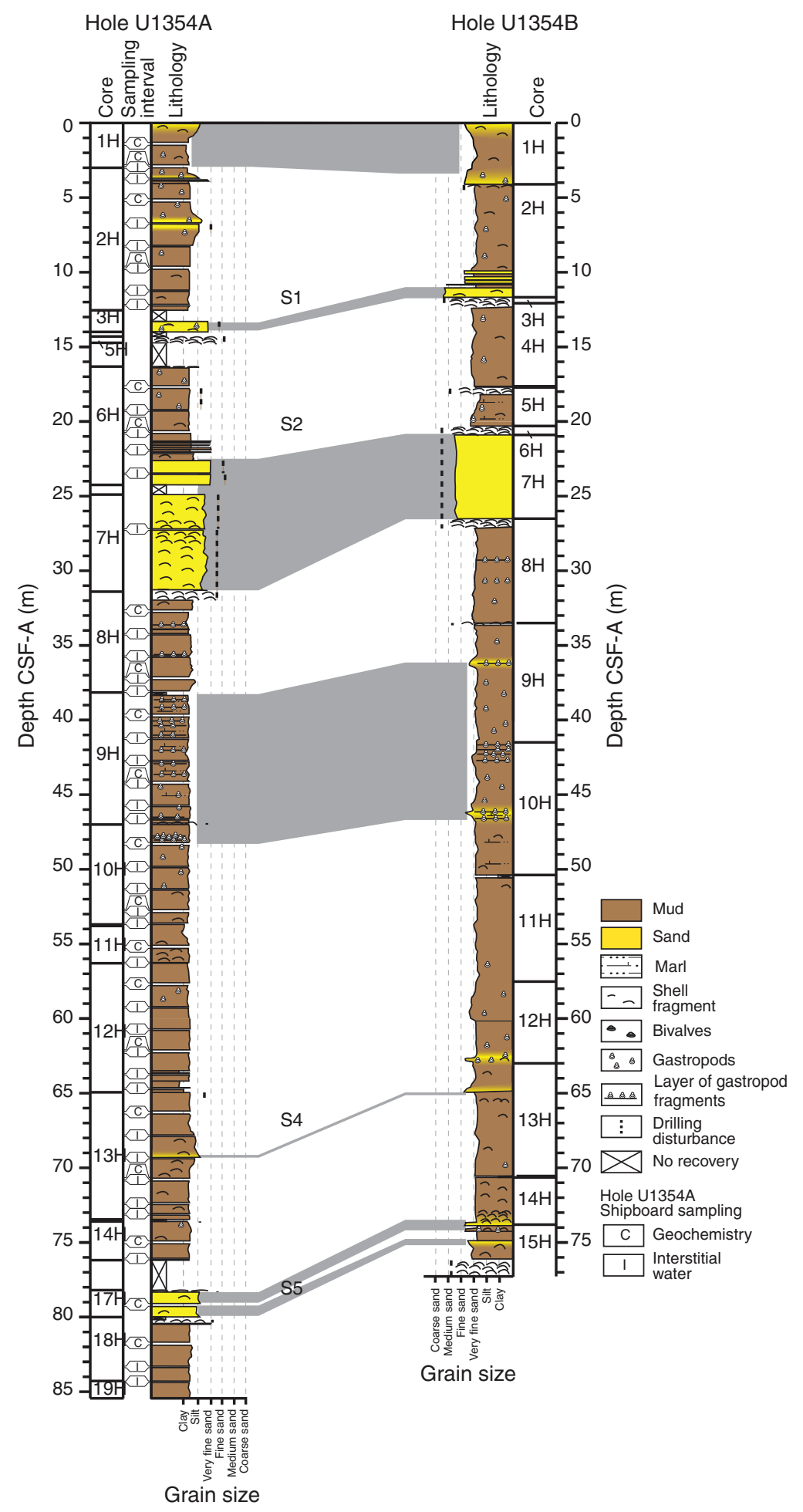


Figure F7. Core photographs of a homogeneous mud lithology from Unit I. A. Homogeneous mud with a trace amount of very fine sand (interval 317-U1354B-8H-3, 60-90 cm). B. Homogeneous mud with rare and scattered shell fragments (interval 317-U1354A-2H-2, 1-31 cm). C. Homogeneous mud with abundant shells dominated by the gastropod Stirocolpus (interval 317-U1354A-6H-1, 20-50 cm).

A

$\mathrm{cm}$

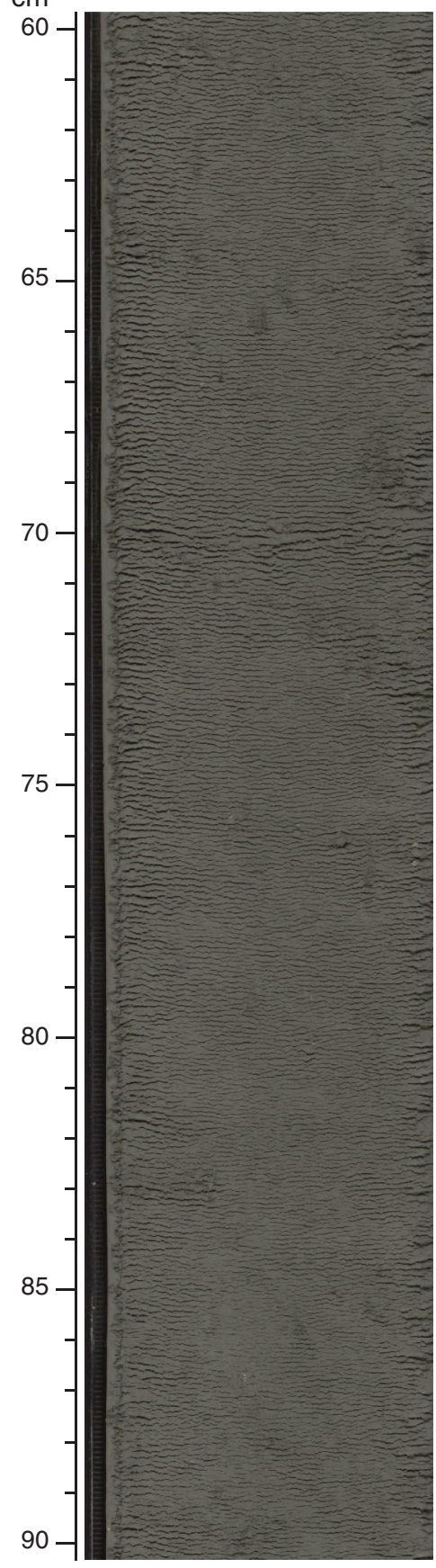

B $\mathrm{cm}$

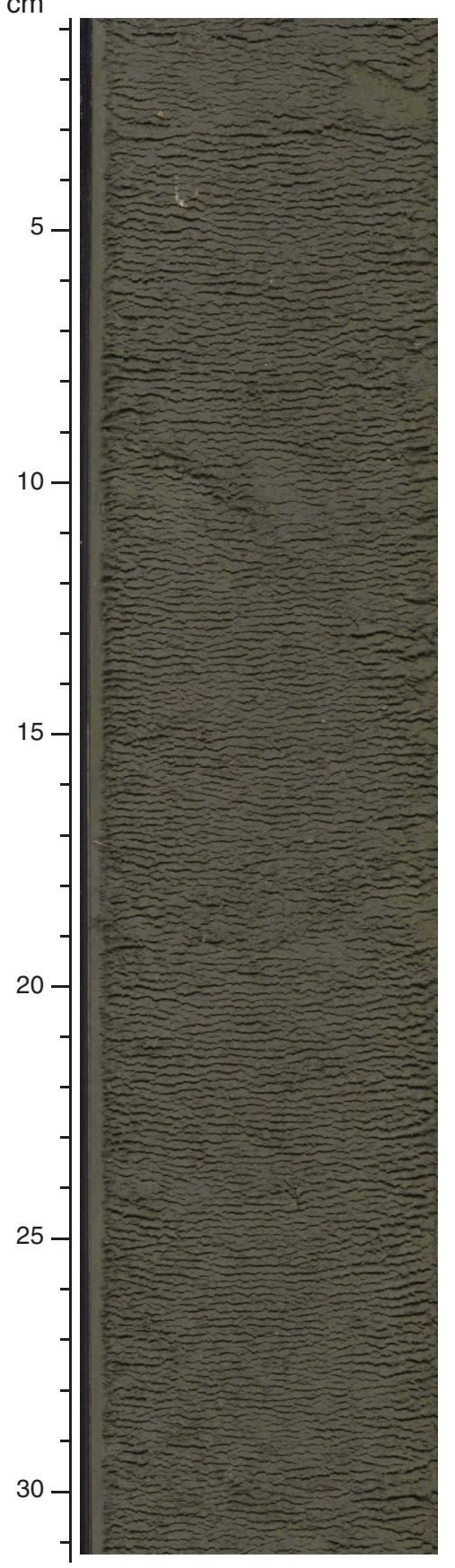

C

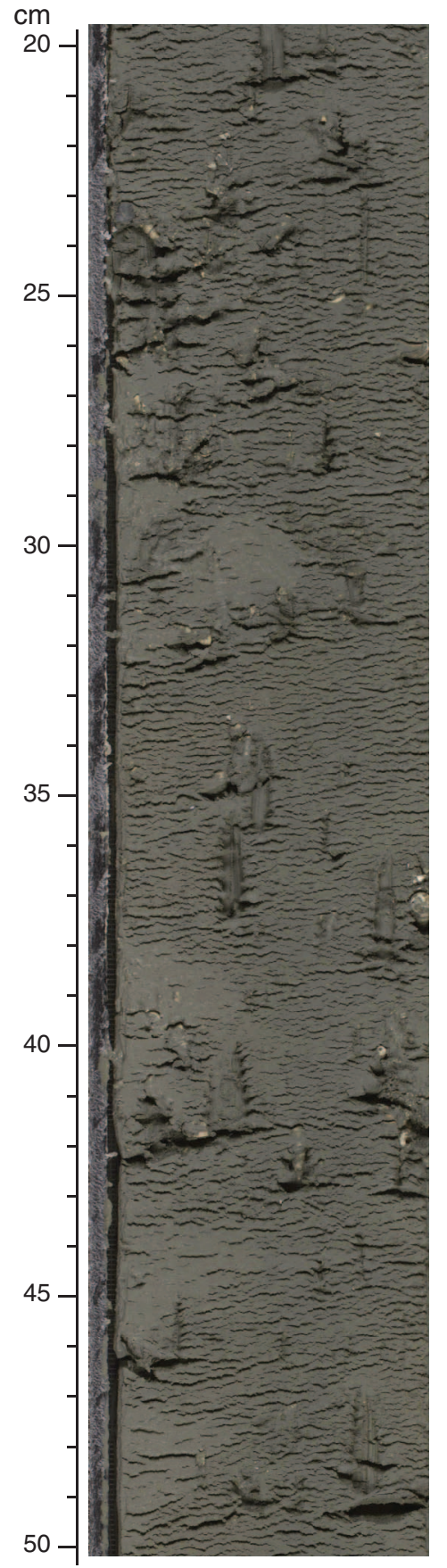


Figure F8. Core photographs of additional Unit I lithologies. A. Very fine-fine micaceous sandy marl, possibly representing the Holocene (interval 317-U1354A-1H-1, 0-30 cm). B. Marl with trace amount of very fine sand (interval 317-U1354B-10H-6, 10-40 cm). C. Clay-rich homogeneous mud (interval 317-U1354A-12H-6, 55-85 $\mathrm{cm})$. D. Clay-rich mud with intercalated normally graded sand laminations (interval 317-U1354C-14X-1, 5-35 $\mathrm{cm})$.

A B

$\mathrm{cm}$

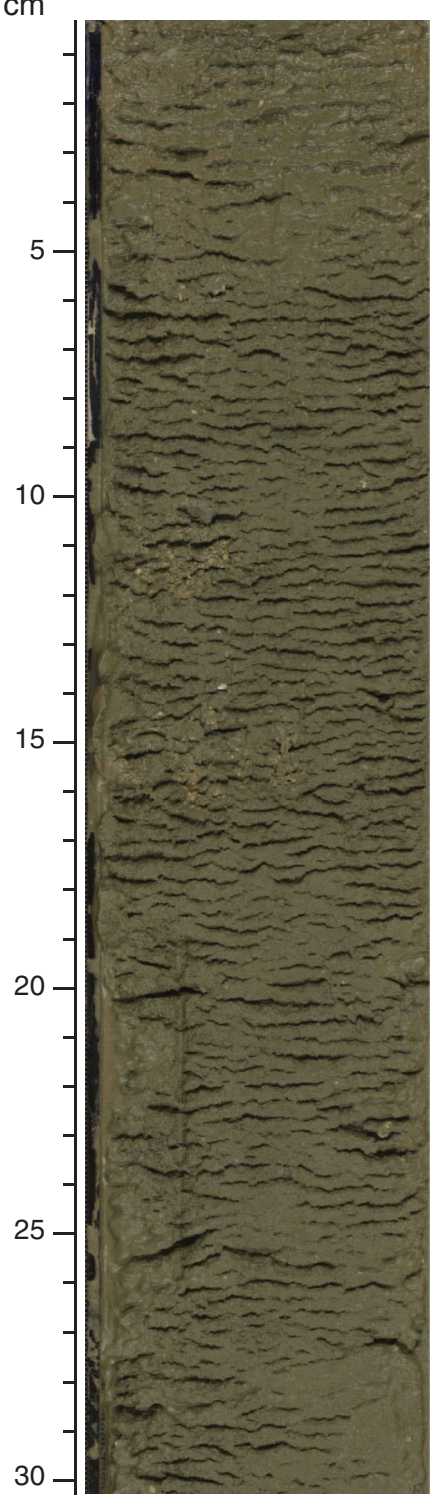

B

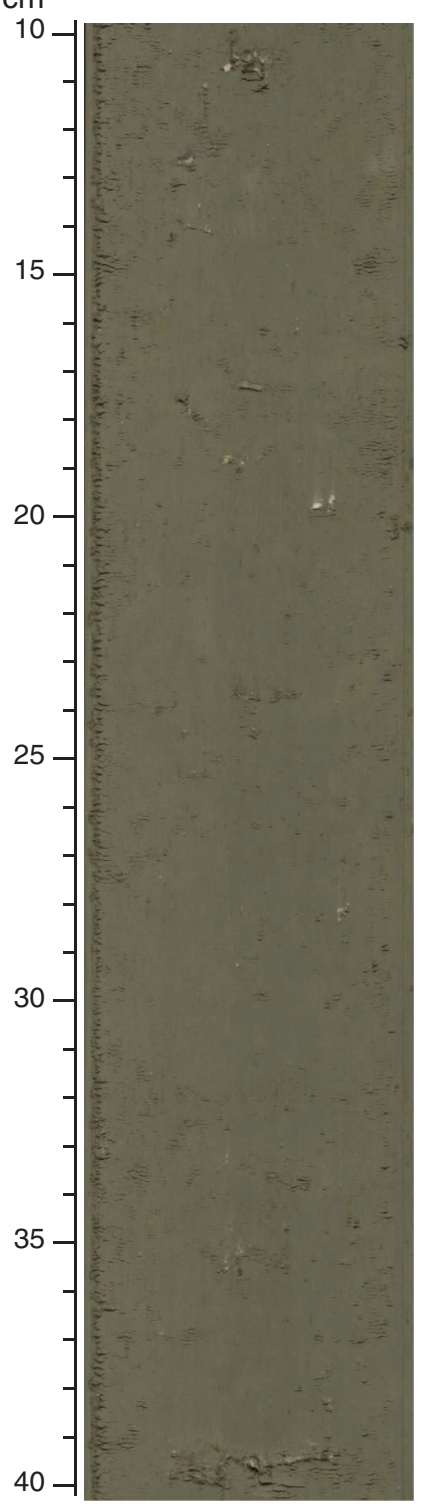

C

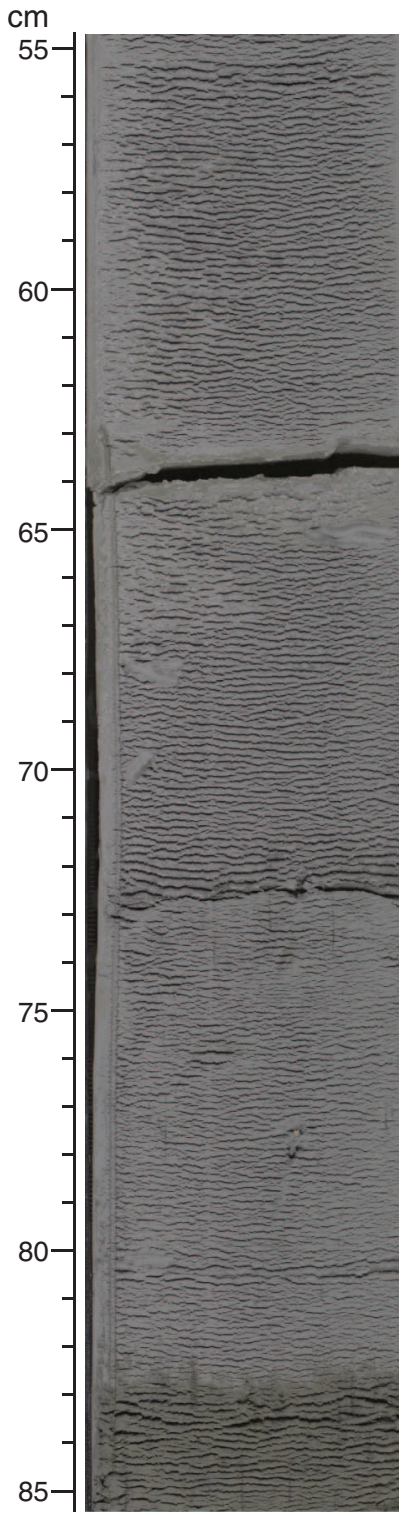

D $\mathrm{cm}$

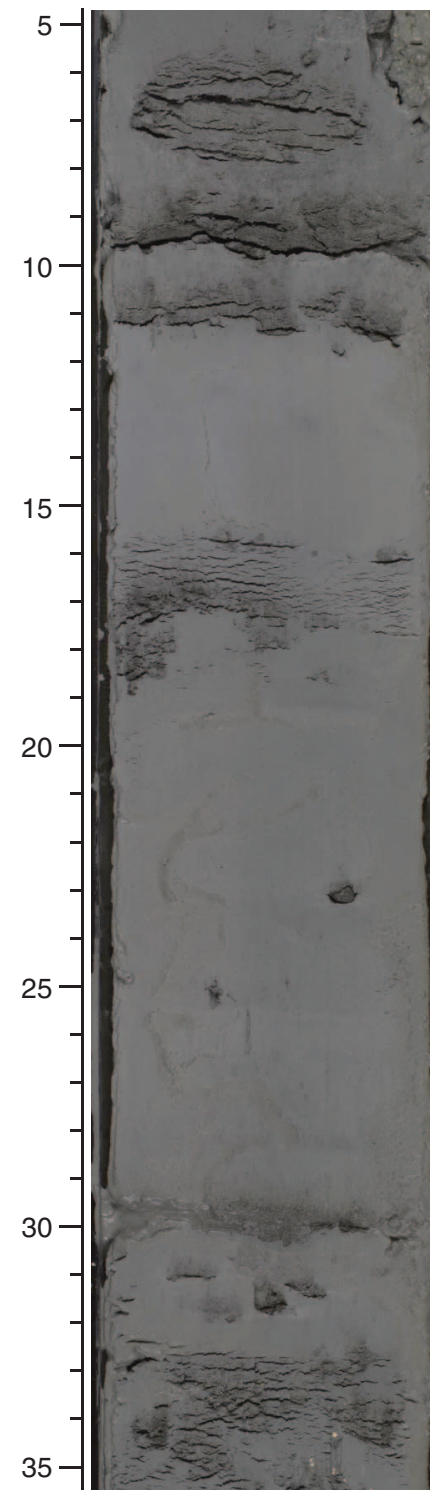


Figure F9. Core photographs of coarser Unit I lithologies. A. Shell hash mixed with fine to medium sand (interval 317-U1354A-5H-1, 5-35 cm). B. Well-sorted, very fine to fine highly micaceous sand with millimeterlong broken shells (interval 317-U1354A-7H-4, 10-40 cm). C. Moderately sorted, very fine-medium very shelly calcareous muddy sand (interval 317-U1354C-5X-1, 40-70 cm). D. Very fine calcareous sandy mud with large clasts, including a bored calcareous nodule (interval 317-U1354B-12H-2, 60-95 cm).

A

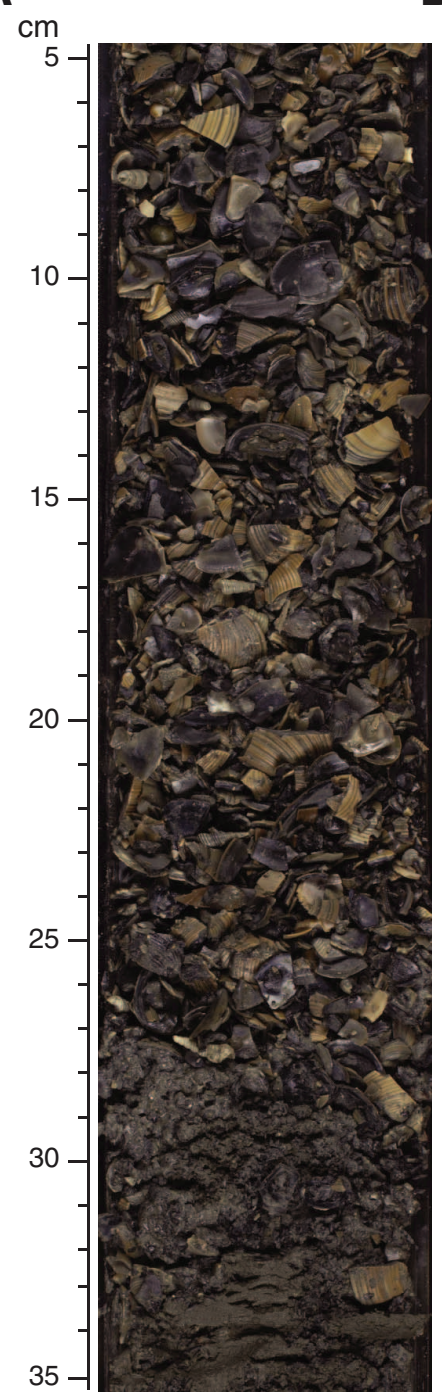

B

$\mathrm{cm}$

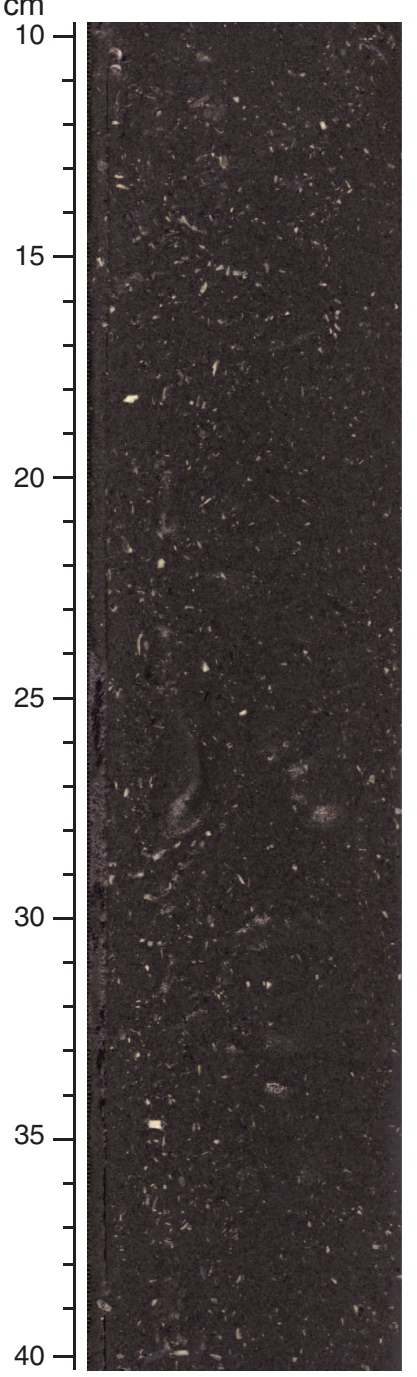

C $\mathrm{cm}$

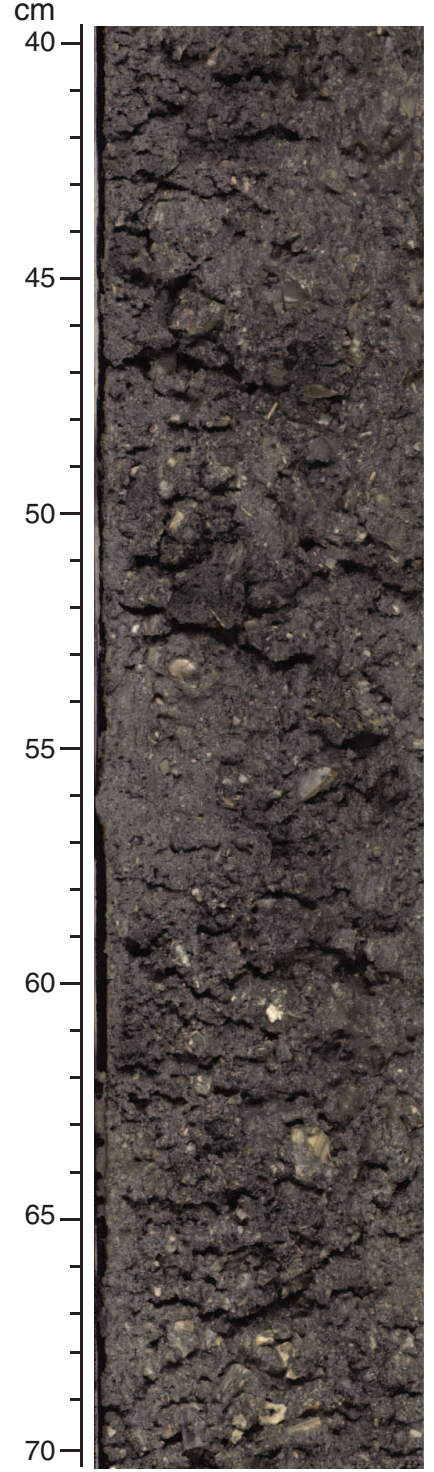

D

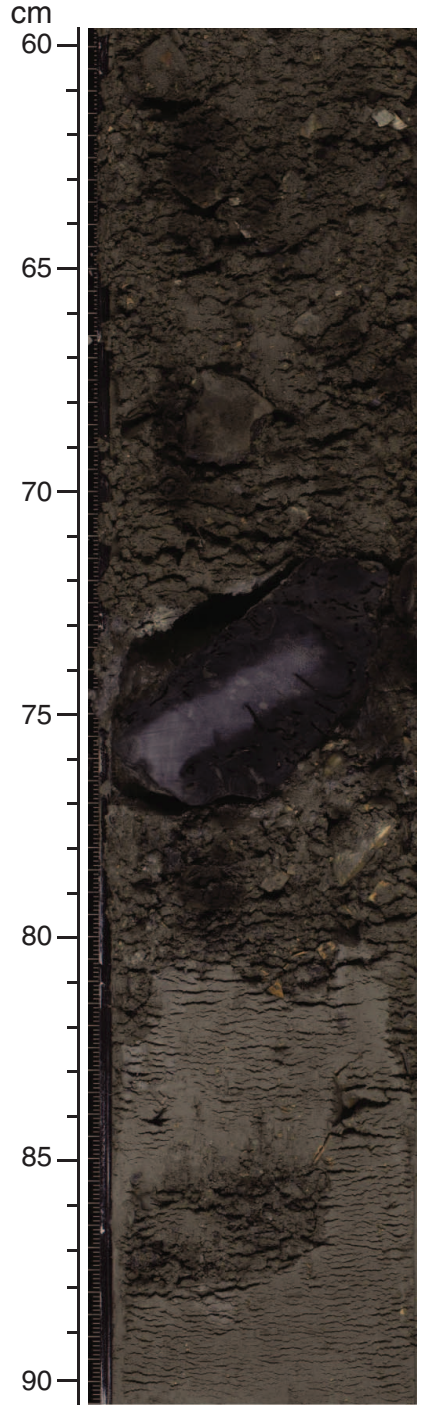


Figure F10. Mineral and textural percentage estimations based on smear slide observations, Site U1354. CaCO ${ }_{3}$ estimates are plotted against data from coulometry analyses for comparison.

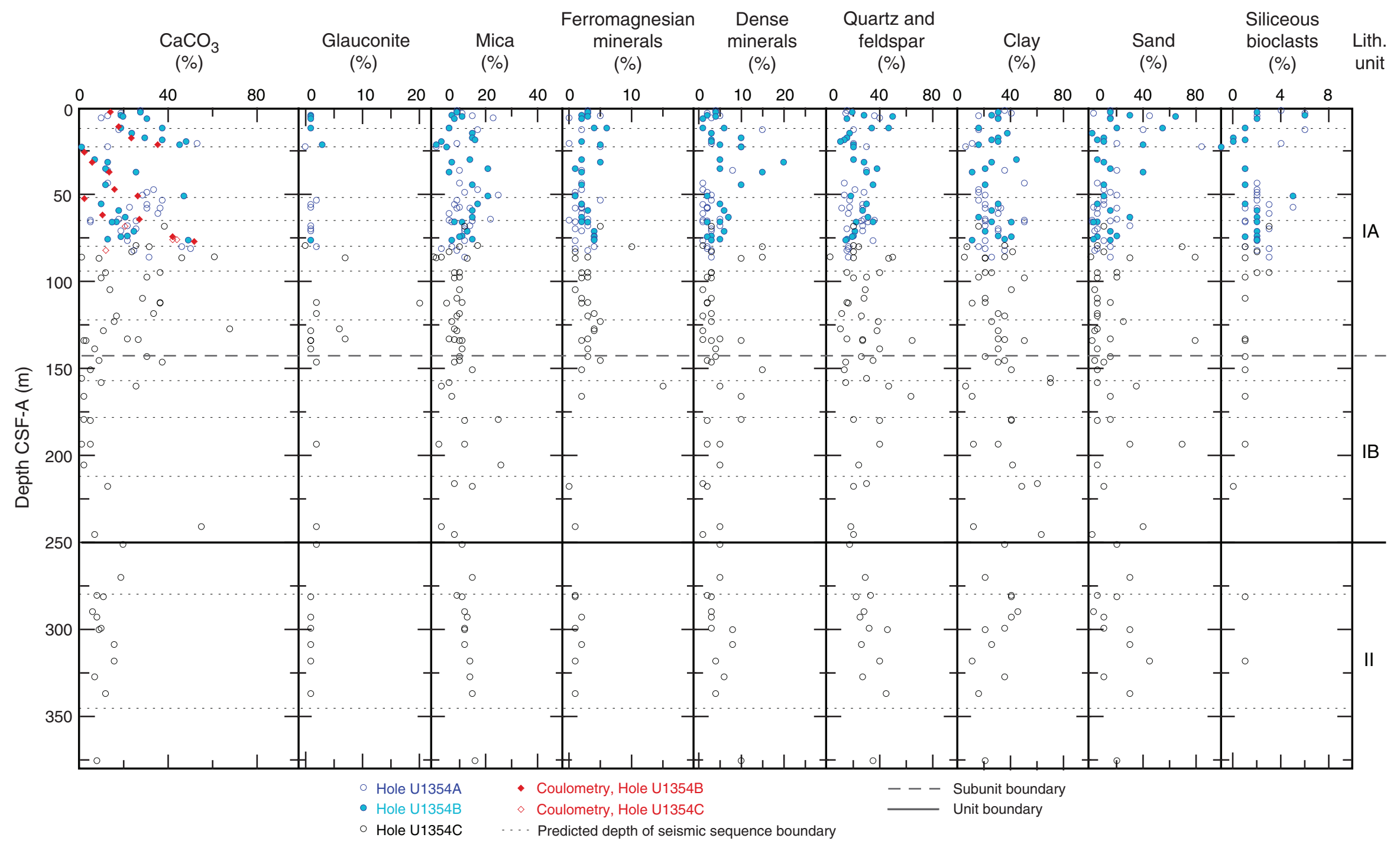


Figure F11. Schematic of possible correlation of uppermost Holocene-Pleistocene succession between Holes U1353B, U1354B, and U1351B. Columns are aligned relative to top depth and distance (not to scale). Distinct lithologic boundaries and two predominant sand beds can be correlated among the columns. Four depositional units are well defined: an uppermost unit of possible Holocene age and three units of possible upper Pleistocene age. The two thick, well-sorted, very fine-fine sand beds at the most landward site (Hole U1353B) thin offshore. Also, the upper sand bed disappears into a sandy interval in Holes U1354B and U1351B.

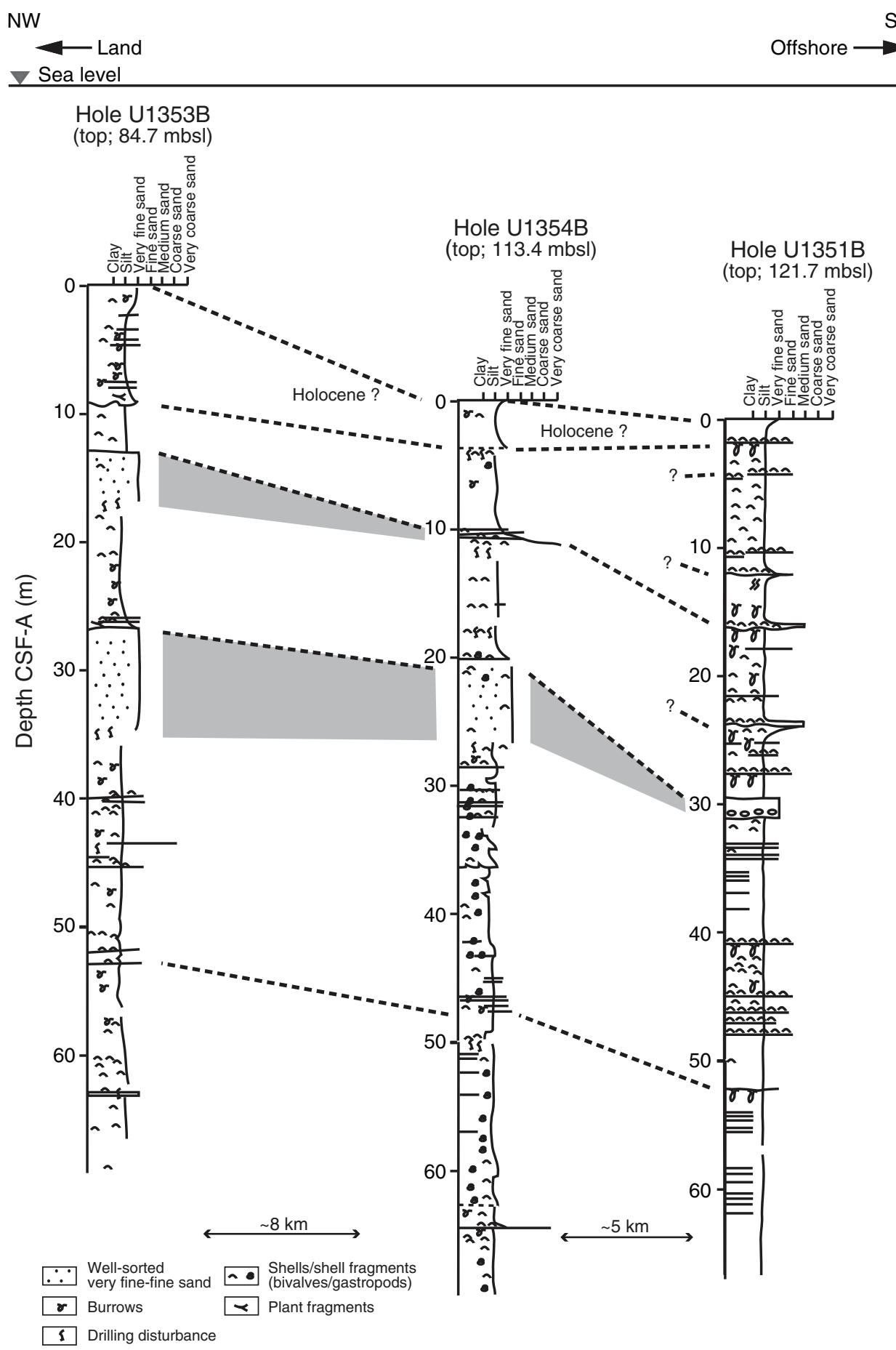


Figure F12. Core photographs of sediment correlation based on lithostratigraphy and paleomagnetic ages. A. Interval 317-U1354A-13H-4, 0-45 cm. B. Interval 317-U1354B-13H-2, 47-102 cm. Both sections show a sharp contact separating gray mud beneath from shelly sand above. The contact is at $69.6 \mathrm{~m}$ in Hole U1354A and at $64.8 \mathrm{~m}$ in Hole U1354B. The sediment beneath the contact is heavily bioturbated. The shelly sand of Section 317-U1354B-13H-2 contains a $7 \mathrm{~cm}$ long limestone clast above the contact. This contact and associated sediments, named surface U1354B-S4 (see Table T3), are tentatively linked to seismic sequence boundary U16 (after Lu and Fulthorpe, 2004), which has a predicted depth of $64 \mathrm{~m}$. Further correlation is provided by paleomagnetic ages, which locate the Brunhes/Matuyama boundary at 65-69 $\mathrm{m}$ in both cores.

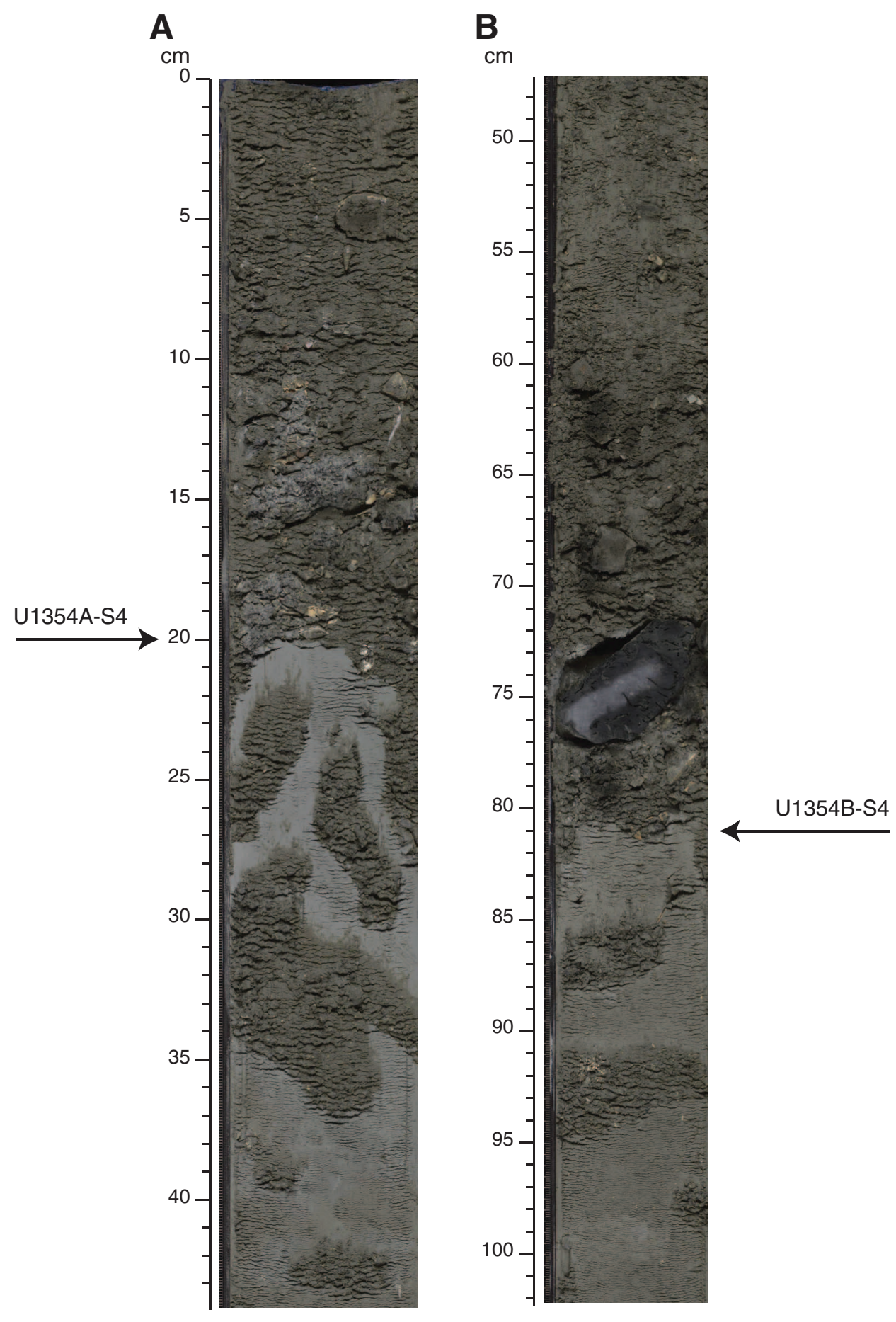


Figure F13. Core recovery, epochs, calcareous nannofossil (NN) zones, and New Zealand (NZ) stage correlation for planktonic foraminifers and bolboforms (PF) and benthic foraminifers (BF), Site U1354. Solid wavy lines = hiatuses between biozones. See Figure F6 in the "Methods" chapter for NZ stage abbreviations.
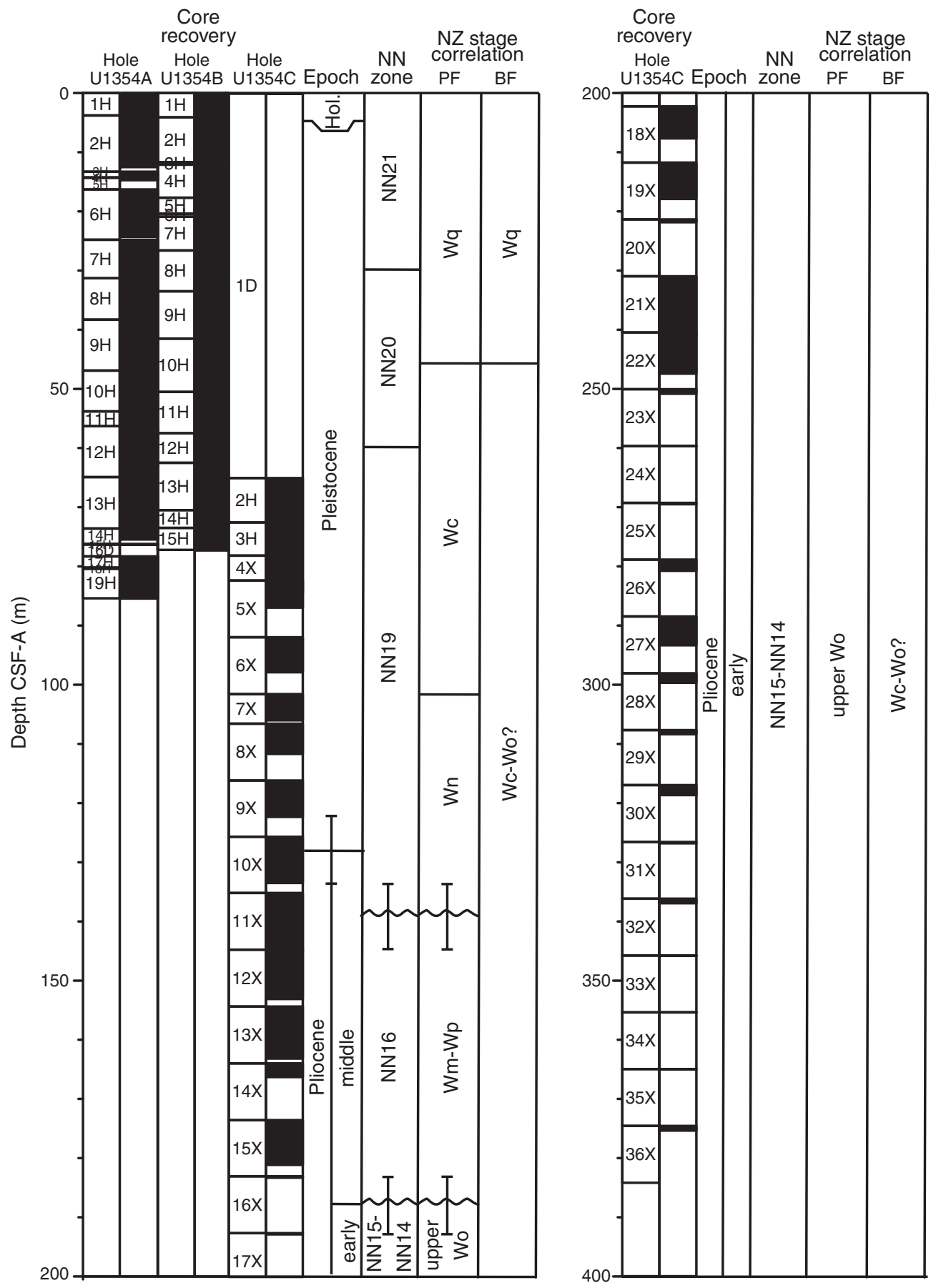
Figure F14. Planktonic foraminiferal abundance relative to total foraminifers and oceanicity, Hole U1354B (see Fig. F7 in the "Methods" chapter).

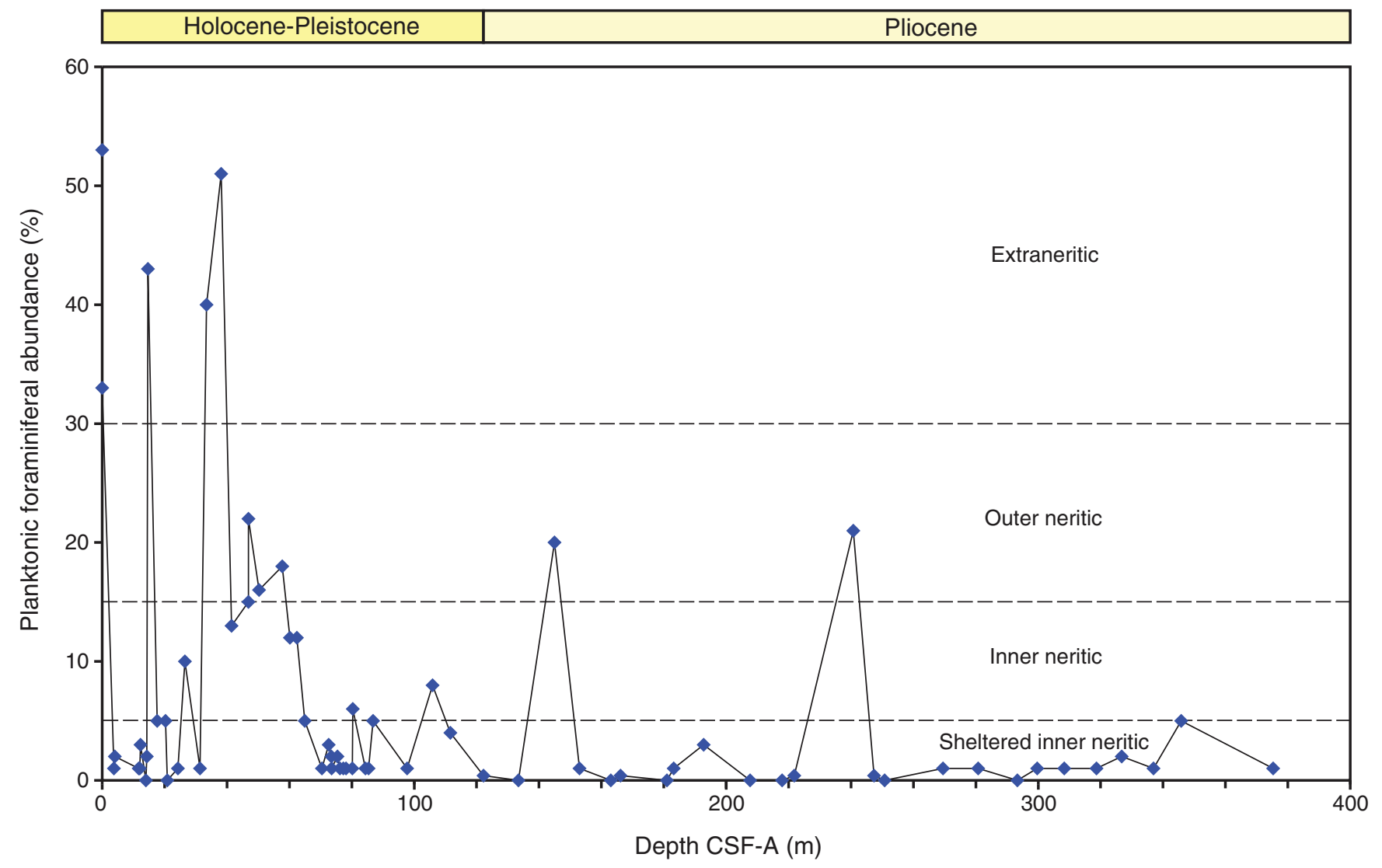


Figure F15. Paleodepth interpretation from benthic foraminifers, Site U1354.
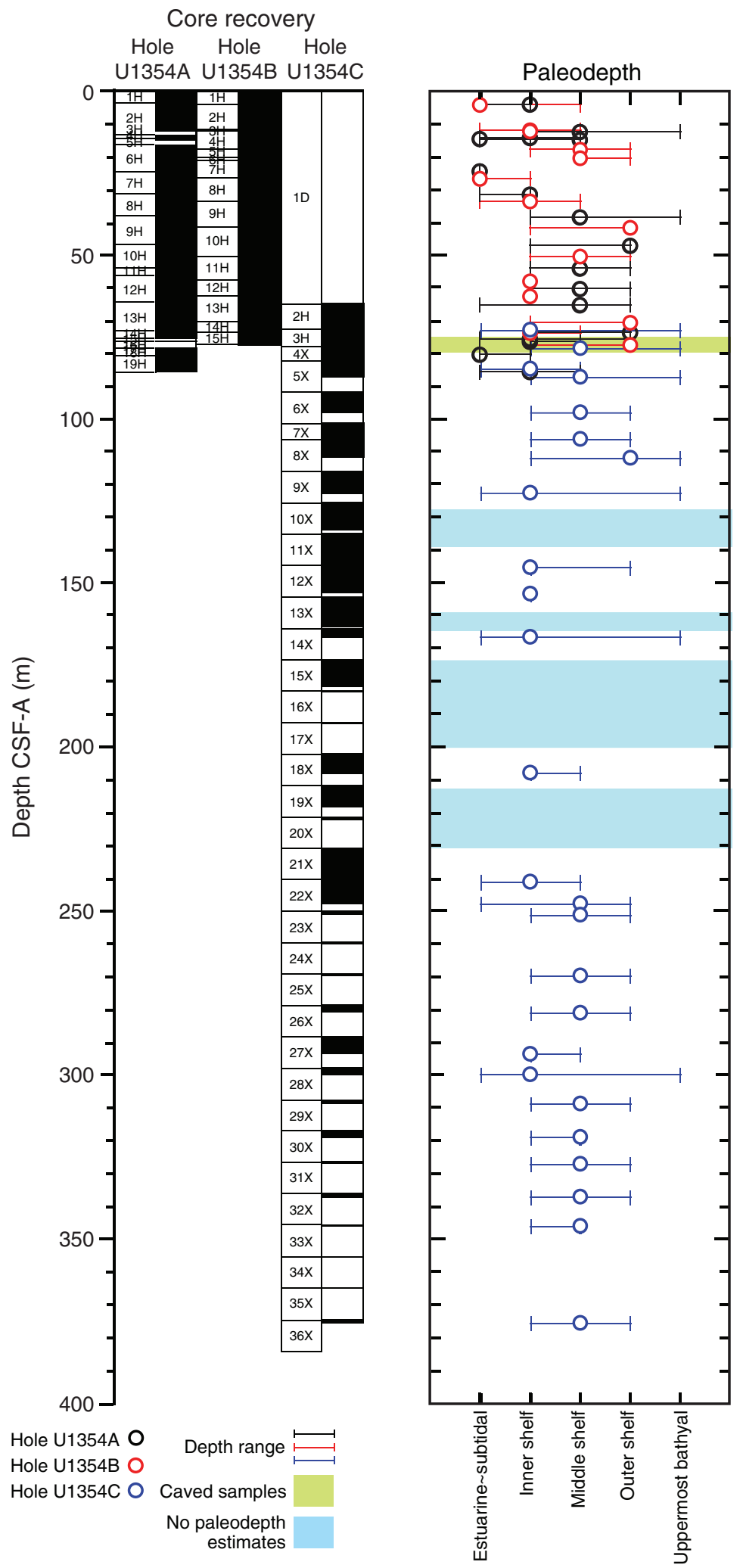

Benthic

foraminifer

Preservation

abundance

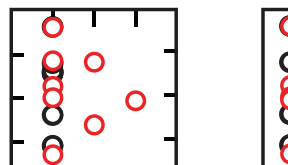

OIIT

8

$-8$

$-8$

- 8

-80 -

$\left[\begin{array}{ll}0 & 0 \\ 0 & 0\end{array}\right.$

\begin{tabular}{lll|l}
0 & -1 \\
& 0 & 0
\end{tabular}

$\left[\begin{array}{ll}0 & 0\end{array}\right]$

- 00 ]

$8-$

$-0,-$

$-81$

$\begin{array}{ll}-0 & - \\ -8 & -1\end{array}$

$\begin{array}{lll}-1 & -1 \\ -1 & 0\end{array}$

- $01-1$

- 0 -

-

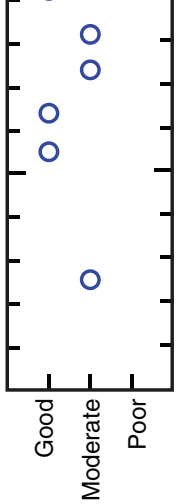

O

$\circ$

$1+1-1$

离 空

ปัํํㅇํㅇ 
Figure F16. Natural remanent magnetization (NRM) paleomagnetic record, Hole U1354A. WRMSL magnetic susceptibility is also shown.

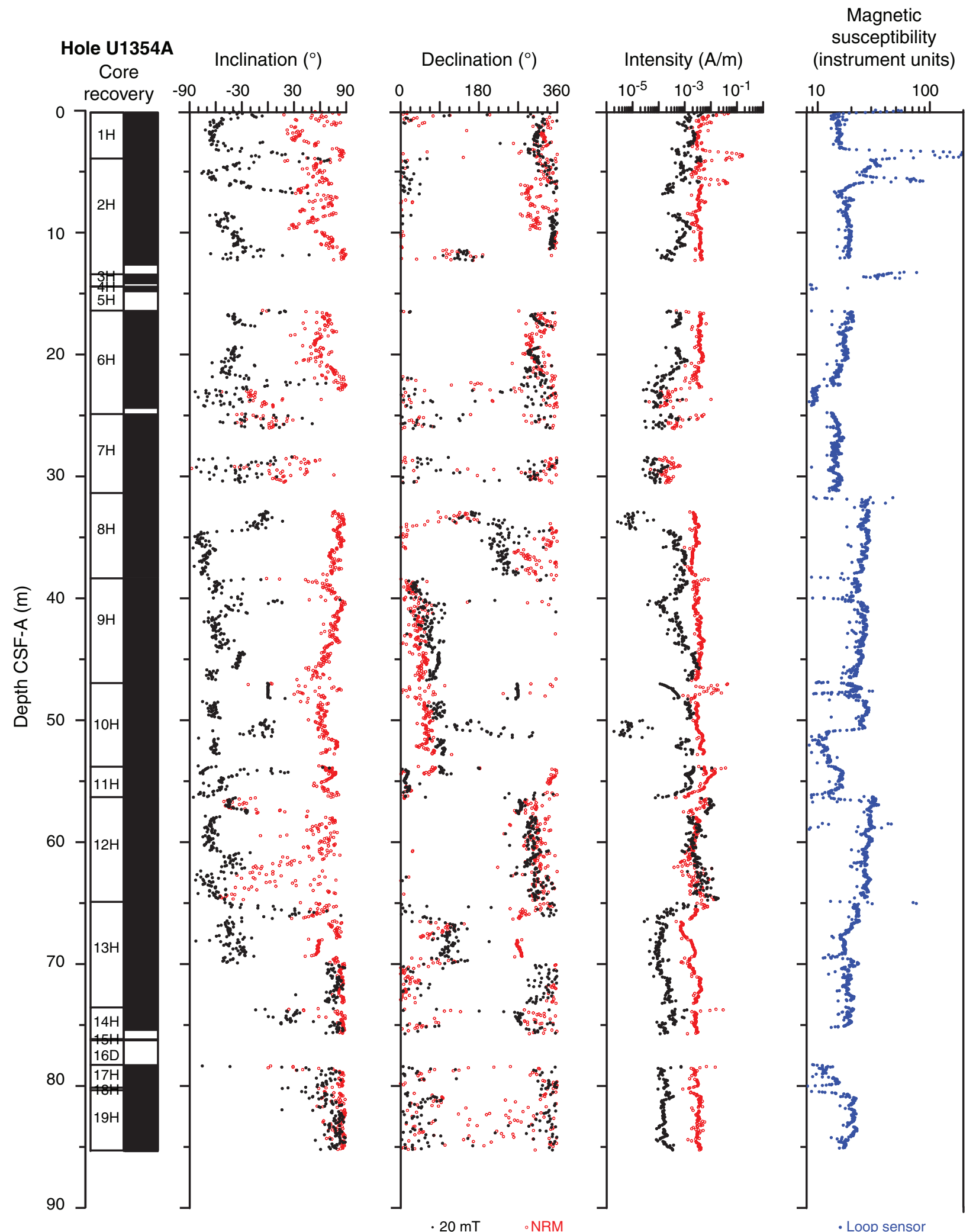


Figure F17. Natural remanent magnetization (NRM) paleomagnetic record, Hole U1354B. WRMSL magnetic susceptibility is also shown.

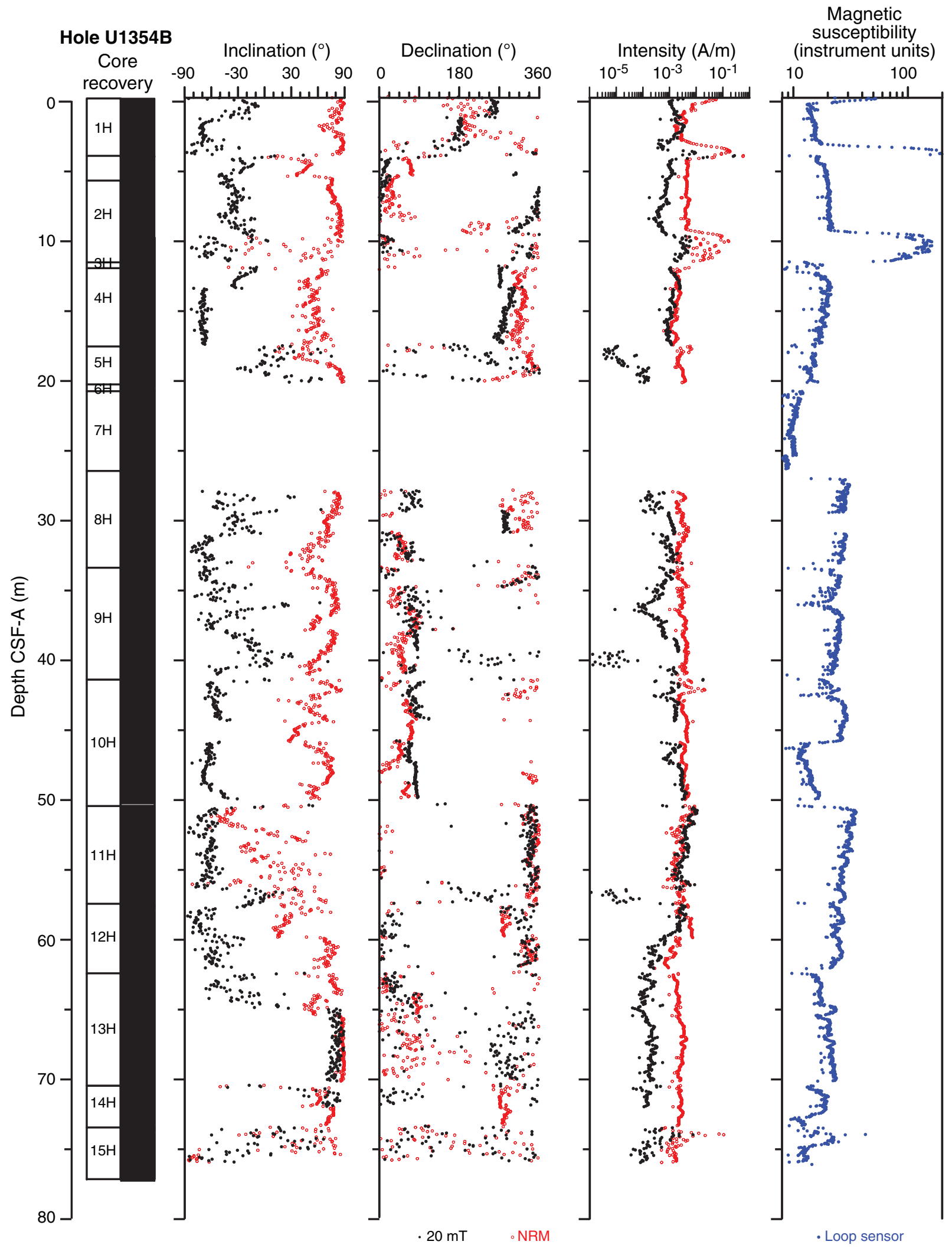


Figure F18. Natural remanent magnetization (NRM) paleomagnetic record, Hole U1354C. WRMSL magnetic susceptibility is also shown.

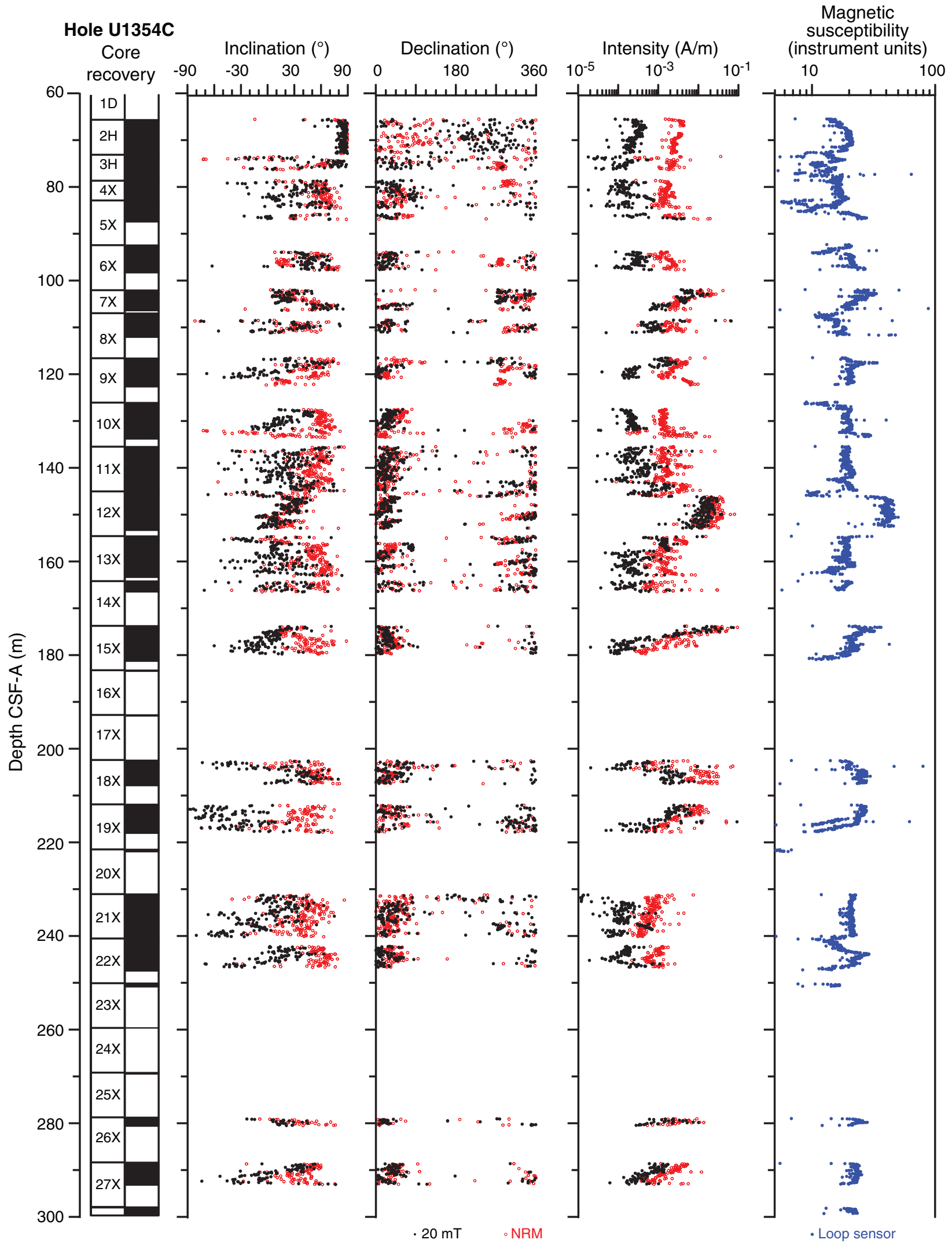


Figure F19. Raw and Gaussian low-pass filtered data for magnetic susceptibility (loop and point sensors), natural gamma radiation (NGR), gamma ray attenuation (GRA) bulk density, and color reflectance parameter $\mathrm{b}^{*}$, Holes U1354B and U1354C. Extreme high and low values, interpreted as noise, are not shown.

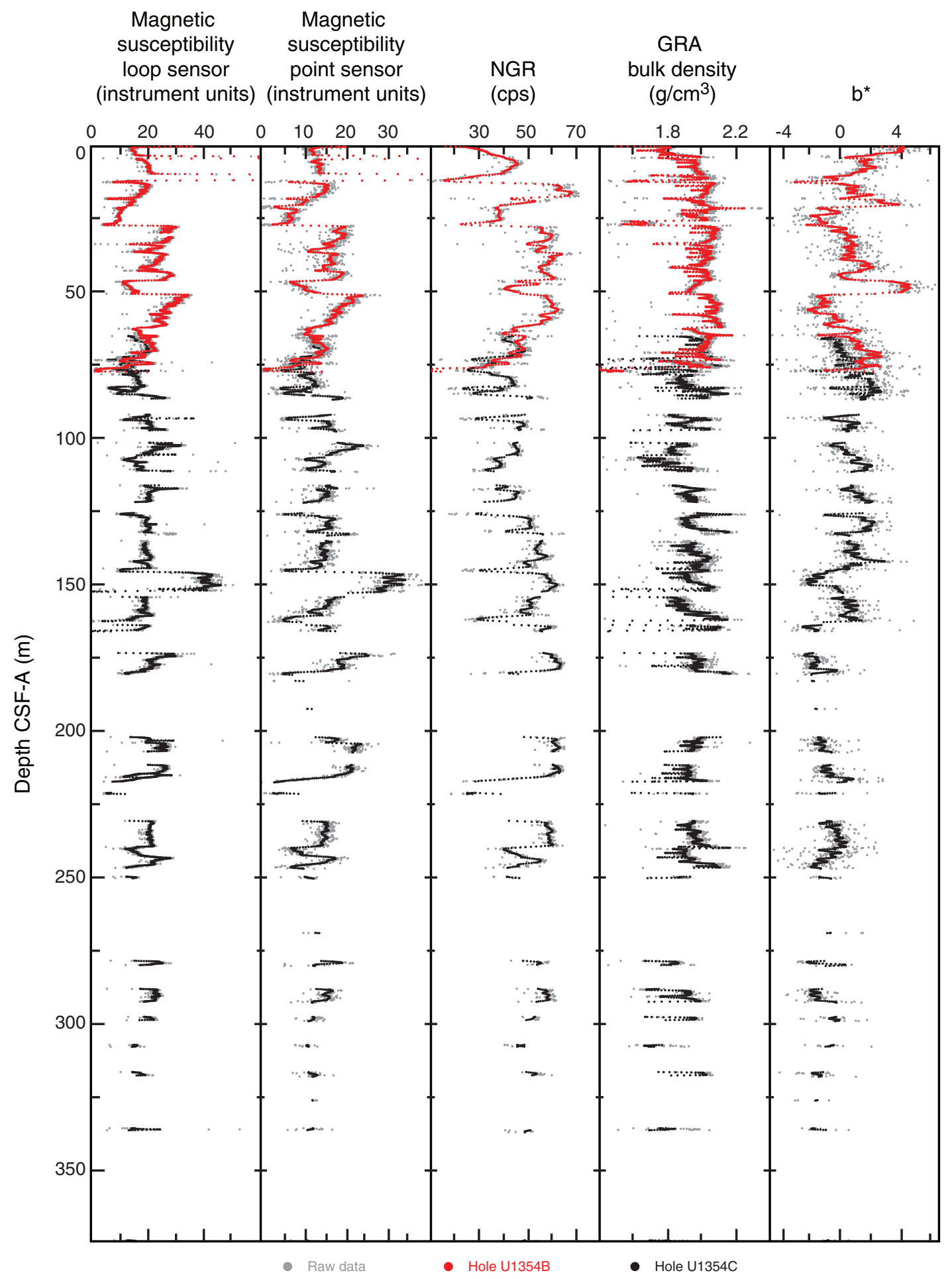


Figure F20. GRA bulk density (red) compared to MAD bulk density (yellow). MAD estimates assuming a systematic 3\% error (green) are also shown. Core recovery (black = recovered intervals) is also shown.

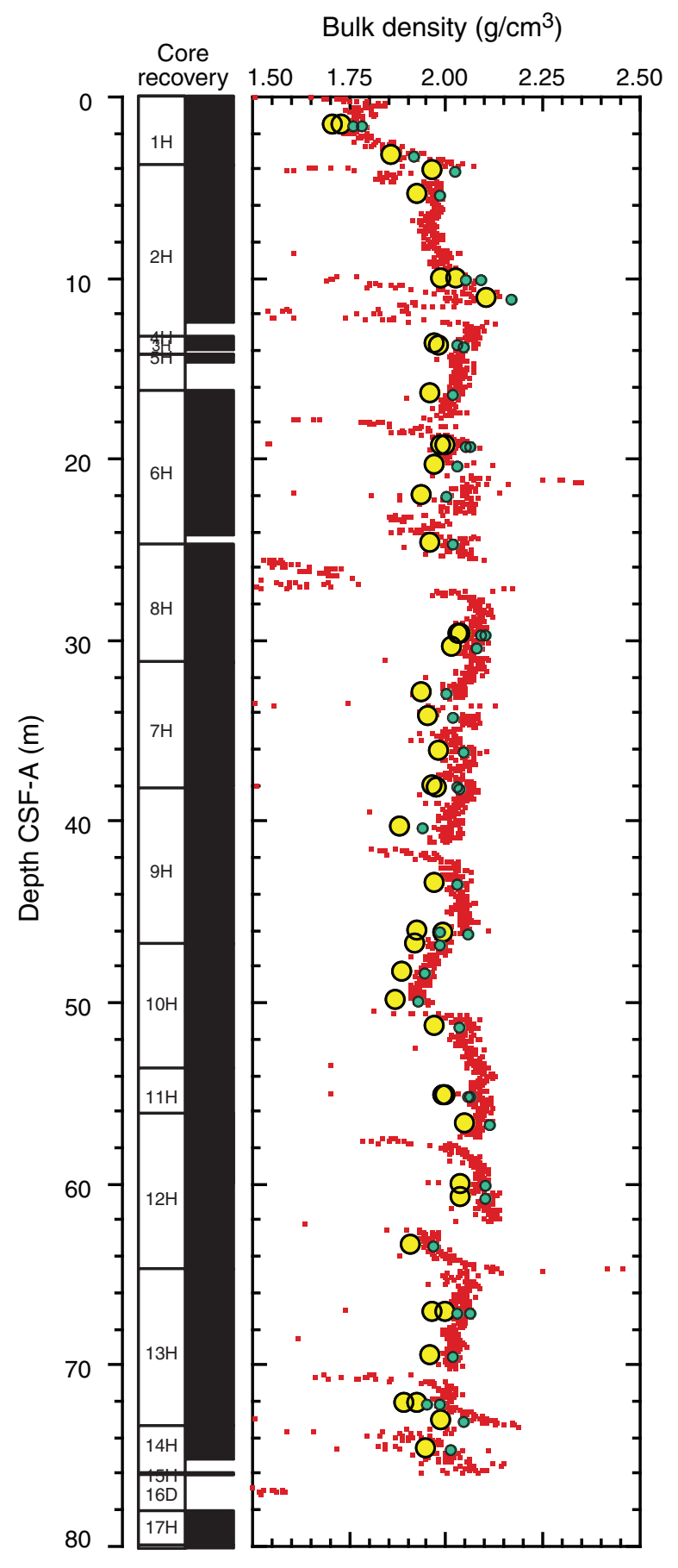


Figure F21. Magnetic susceptibility (loop sensor) and natural gamma radiation (NGR), Holes U1354A and U1354B. Dashed lines at 56-60 m indicate the "overlapping problem" in Hole U1354A, for which $>100 \%$ recovery was reported.

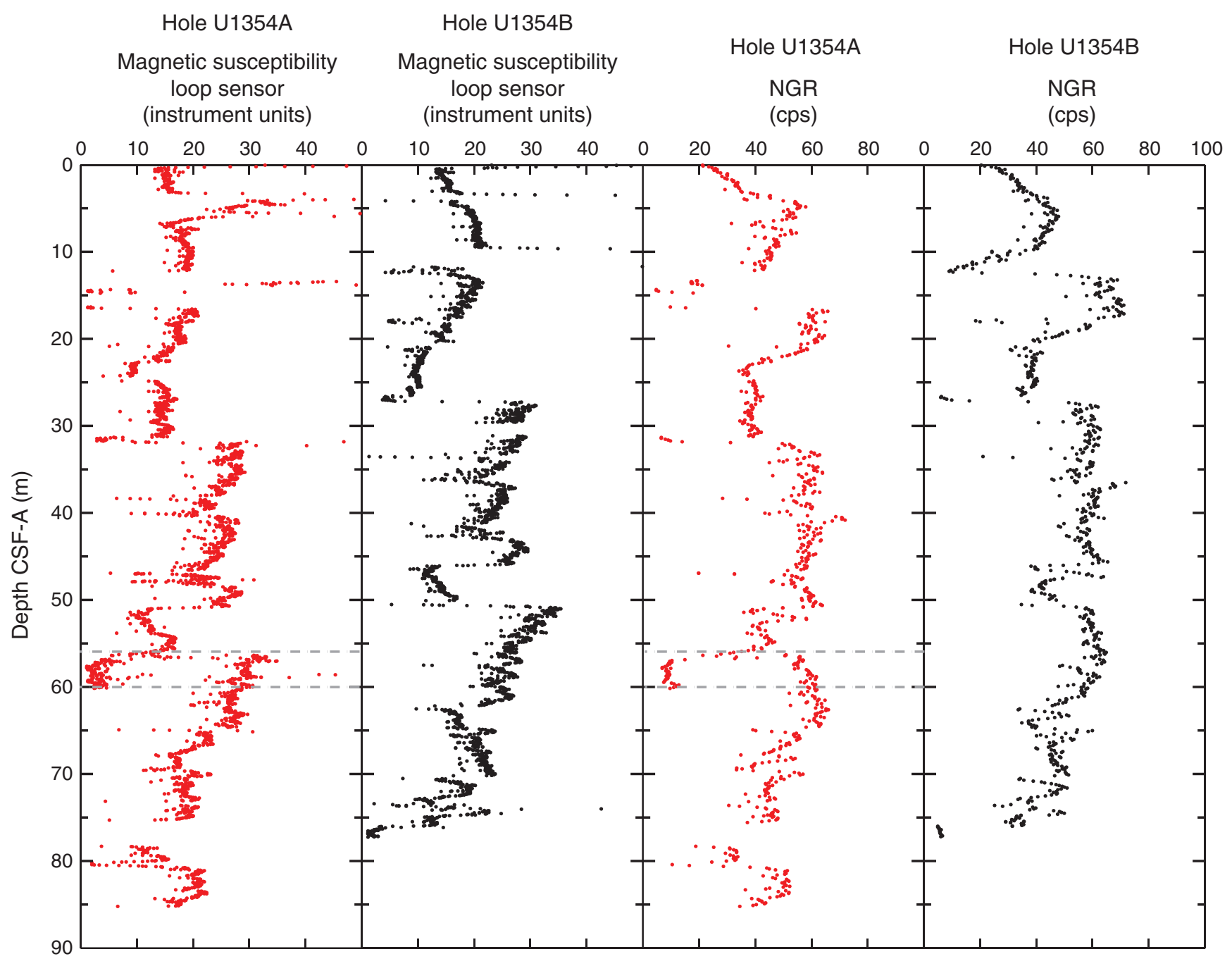


Figure F22. (A, B, D) Whole-round and (C, E) section-half $P$-wave velocities, Holes U1354A, U1354B, and U1354C. $\mathrm{PWL}=P$-wave logger, $\mathrm{PWC}=P$-wave caliper, $\mathrm{PWB}=P$-wave bayonets.
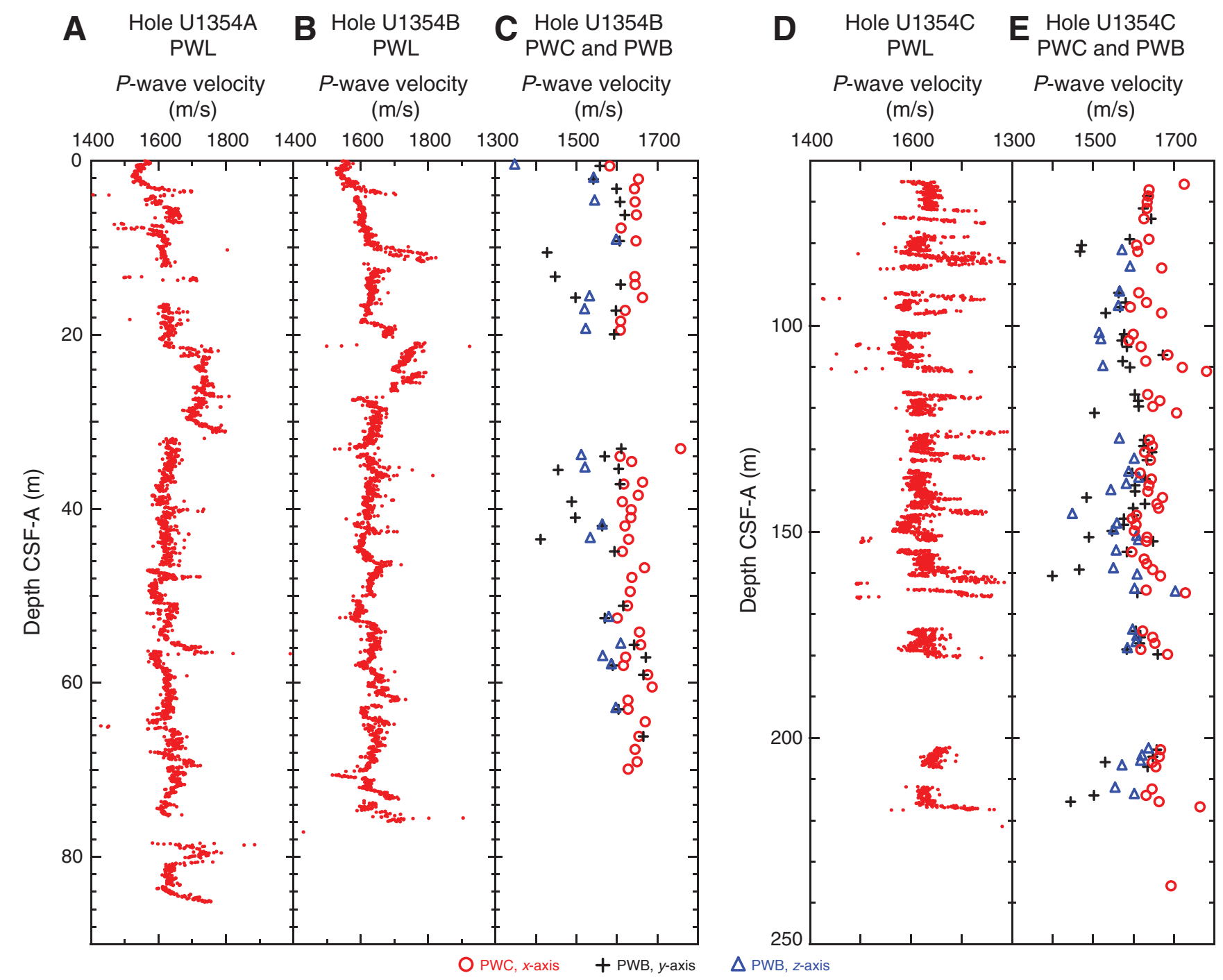
Figure F23. $\mathrm{L}^{*} \mathrm{a}^{*} \mathrm{~b}^{*}$ color parameters in uppermost $80 \mathrm{~m}$ of Hole U1354B, plotted against natural gamma radiation (NGR) and magnetic susceptibility (loop and point sensors). Note that the similar NGR and magnetic susceptibility values obtained from dominantly sand and marl lithologies show different color characteristics.

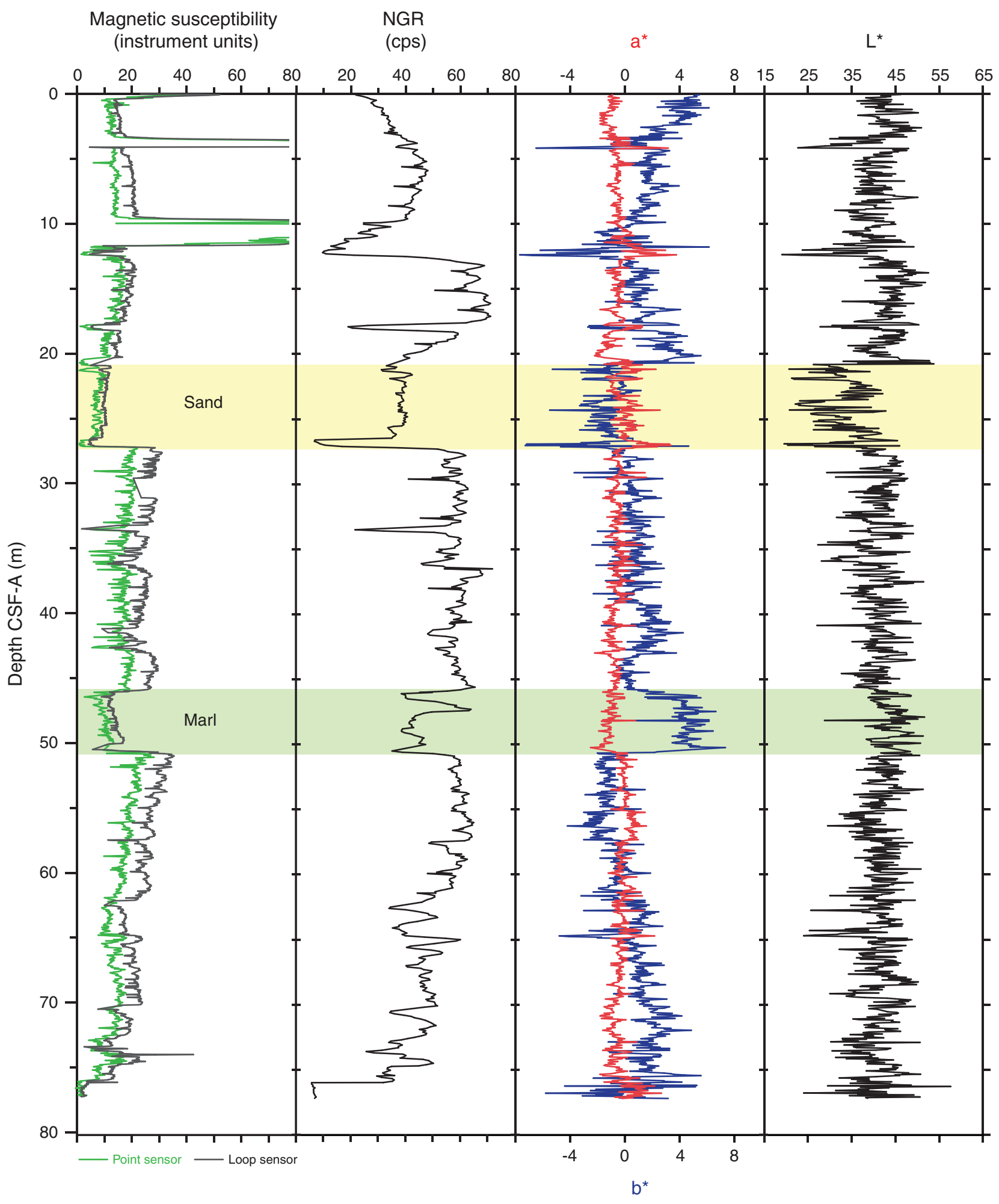


Figure F24. Porosity from MAD catwalk samples compared with adjacent samples from the sample table, Hole U1354B. A. Cross-plot of porosities resulting from the two sampling methods. Samples below the red line had more water on the sample table and those above the line had more water when collected immediately on the catwalk. The linear correlation between the two is shown. B. Porosities plotted as a function of depth. Yellow = catwalk samples, blue $=$ sample table samples.

A

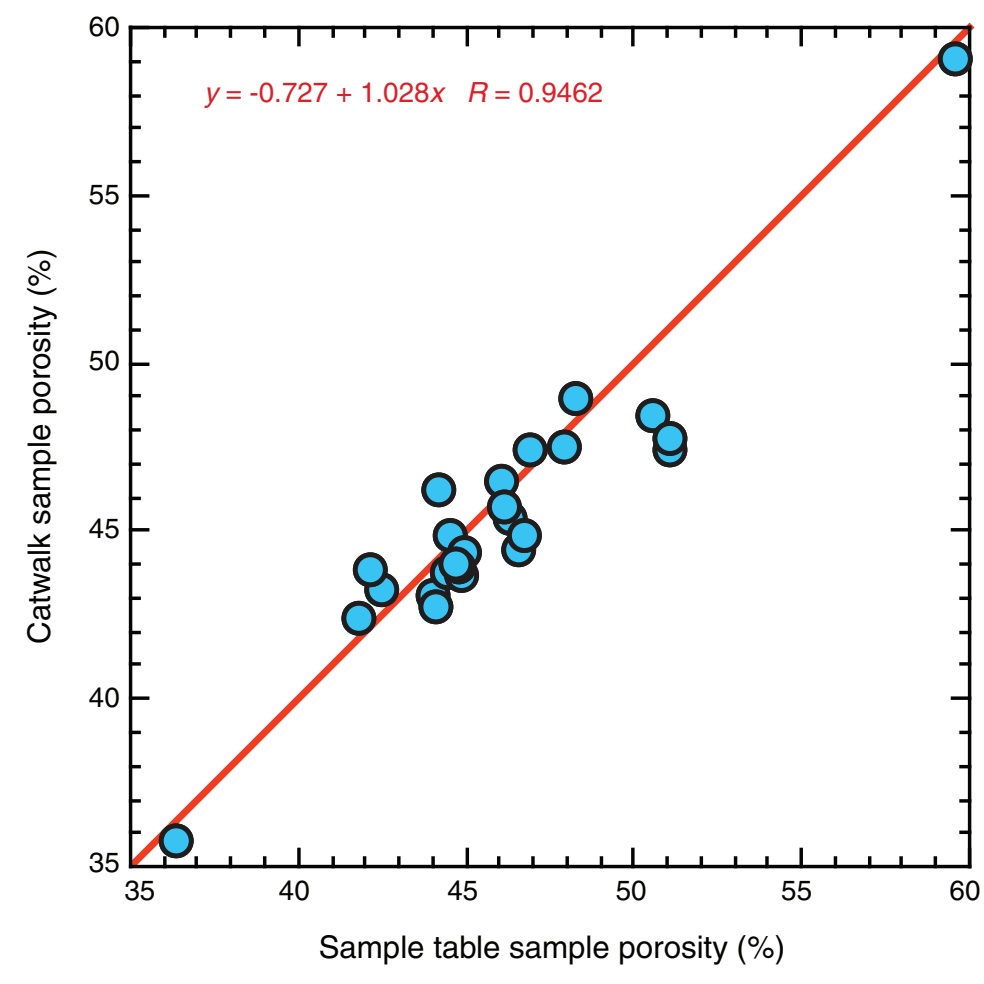

B

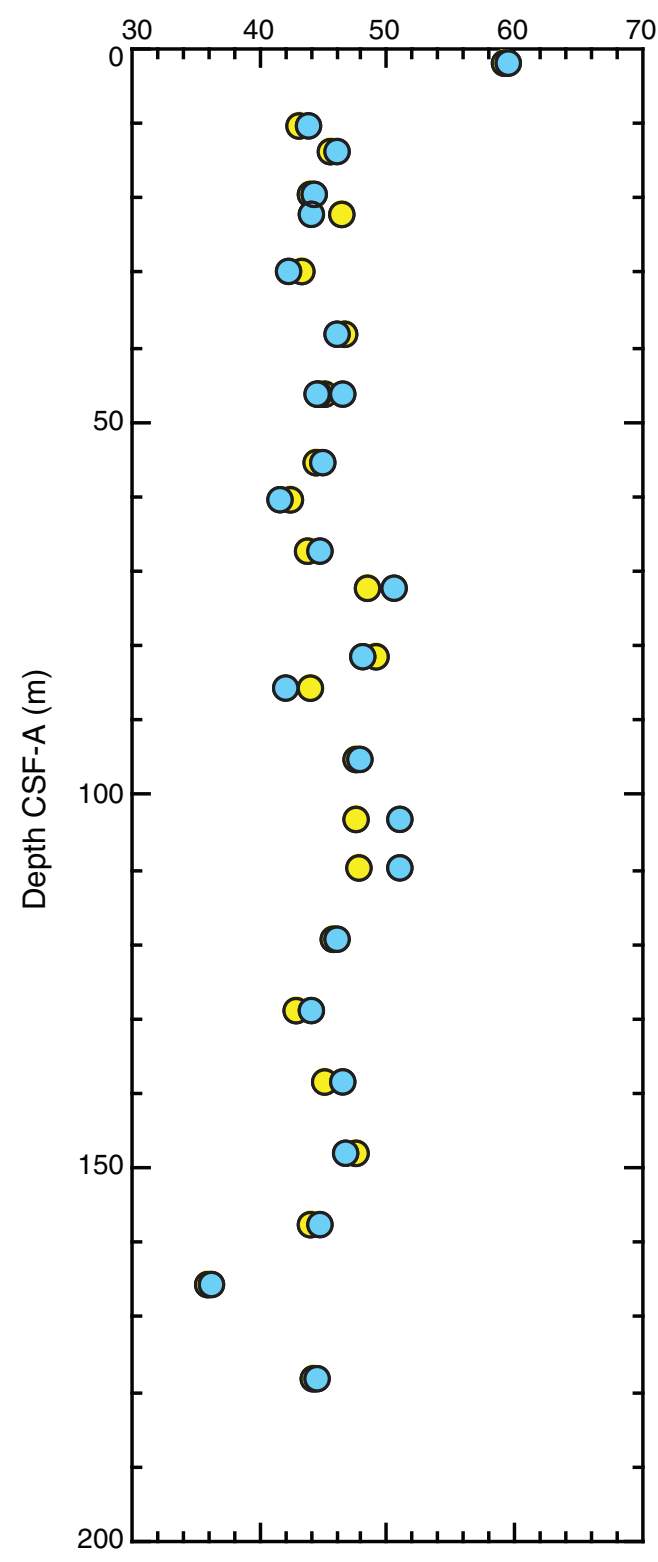


Figure F25. Bulk density, grain density, porosity, and void ratios, Hole U1354B (red-rimmed circles) and U1354C (black-rimmed circles). Core recovery information (black = recovered intervals) is also shown.

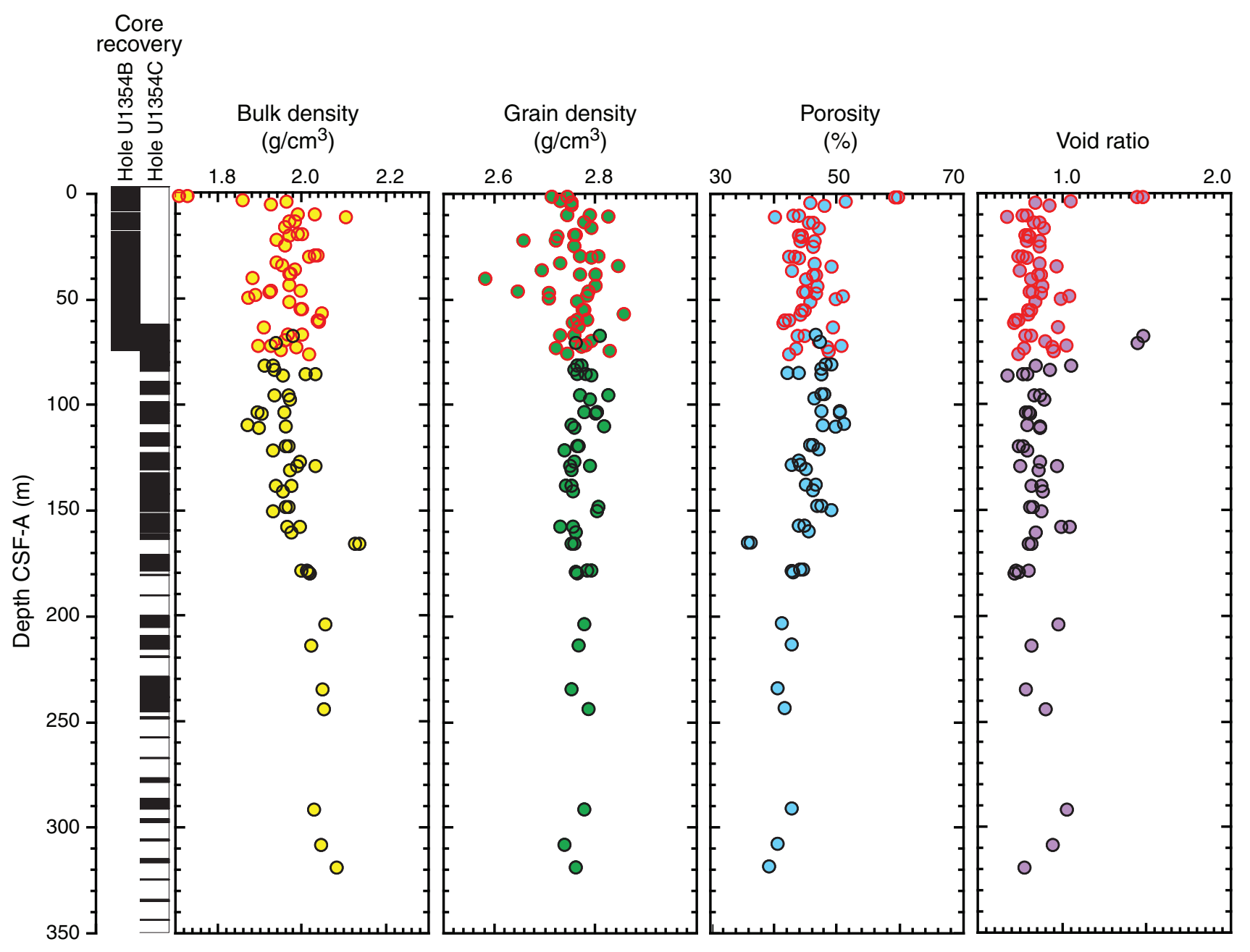


Figure F26. (A) Automated vane shear (AVS) and (B) fall cone penetrometer (FCP) shear strength and (C) crossplot of AVS and FCP data, Holes U1354B (red) and U1354C (black). AVS test results are given as a function of pressure in pascals $\left(\mathrm{kPa}=\mathrm{kN} / \mathrm{m}^{2}\right)$, whereas FCP test results are given in terms of newtons of $\mathrm{kN} / \mathrm{m}^{2}$.

A Automated vane shear $\mathrm{S}_{\mathrm{u}}(\mathrm{kPa})$

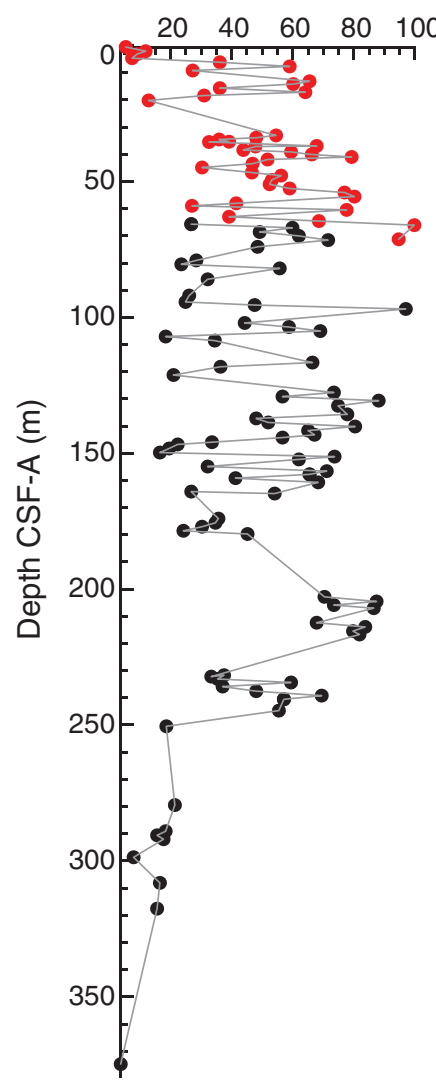

B Fall cone penetrometer

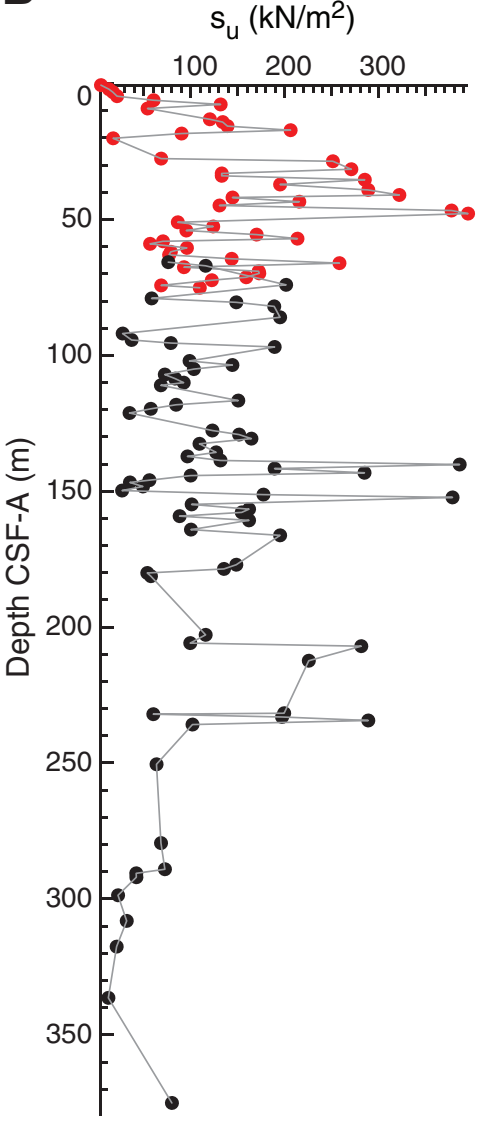

C

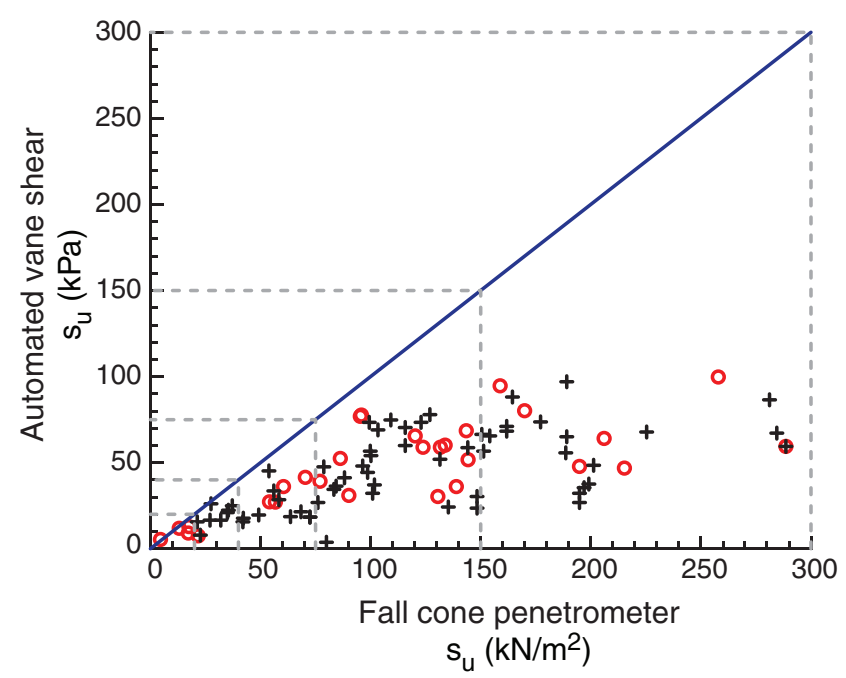

o Hole U1354B + Hole U1354C 
Figure F27. Gas concentrations (parts per million by volume [ppmv]) vs. depth, Holes U1354A (circles) and U1354C (squares). A. Methane $\left(\mathrm{C}_{1}\right)$, ethane $\left(\mathrm{C}_{2}\right)$, and $\mathrm{CO}_{2}$ in headspace (HS) gas. B. Ratio of methane to ethane $\left(\mathrm{C}_{1} / \mathrm{C}_{2}\right)$ in HS gas.

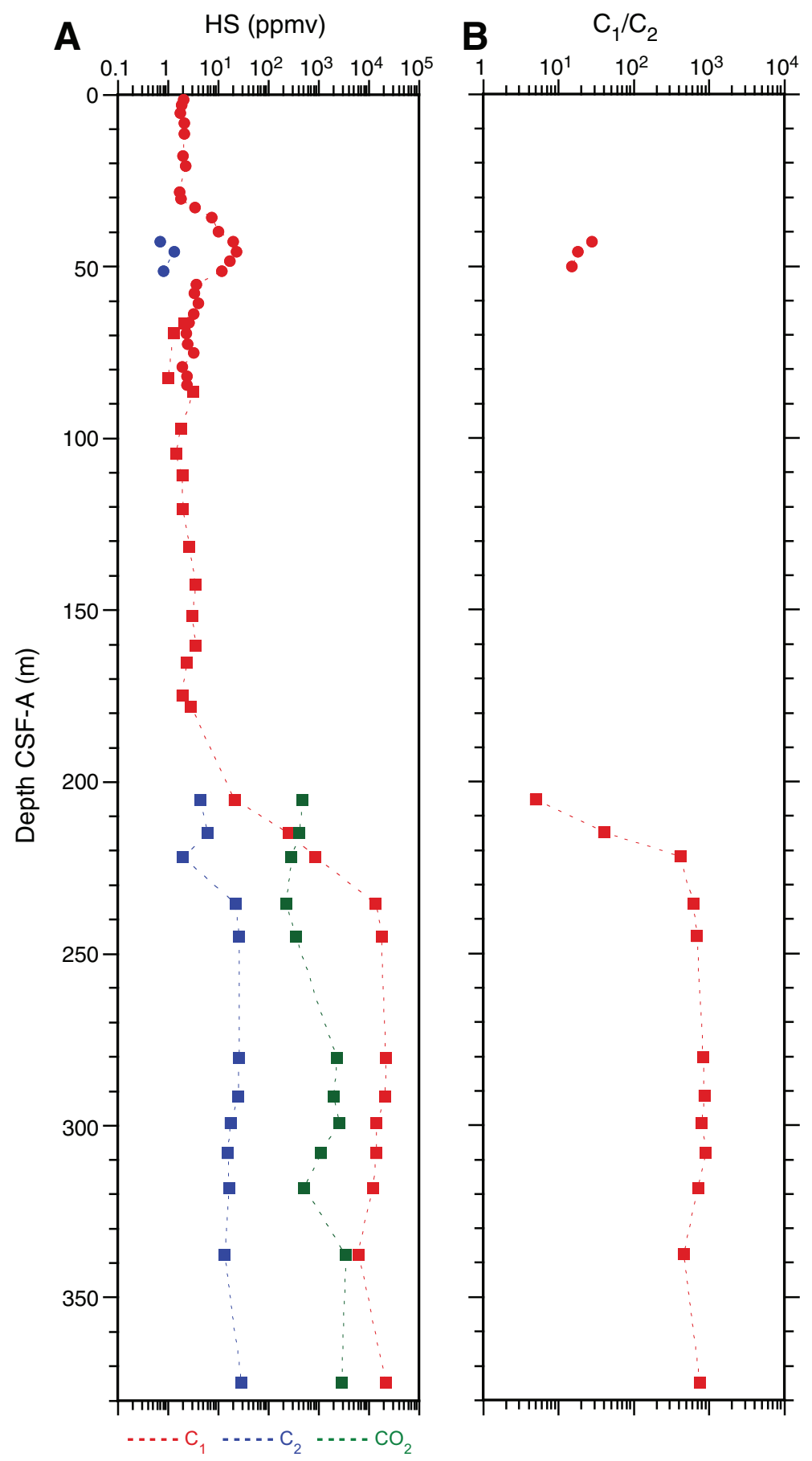


Figure F28. Plots of sediment elemental concentrations vs. depth, Holes U1354B (black) and U1354C (red). A. Carbonate carbon (as $\mathrm{CaCO}_{3}$ ). B. Total carbon. C. Total nitrogen. D. Total organic carbon by difference $\left(\mathrm{TOC}_{\text {DIFF }}\right)$. E. Ratio of $\mathrm{TOC}_{\text {DIFF }}$ to total nitrogen.

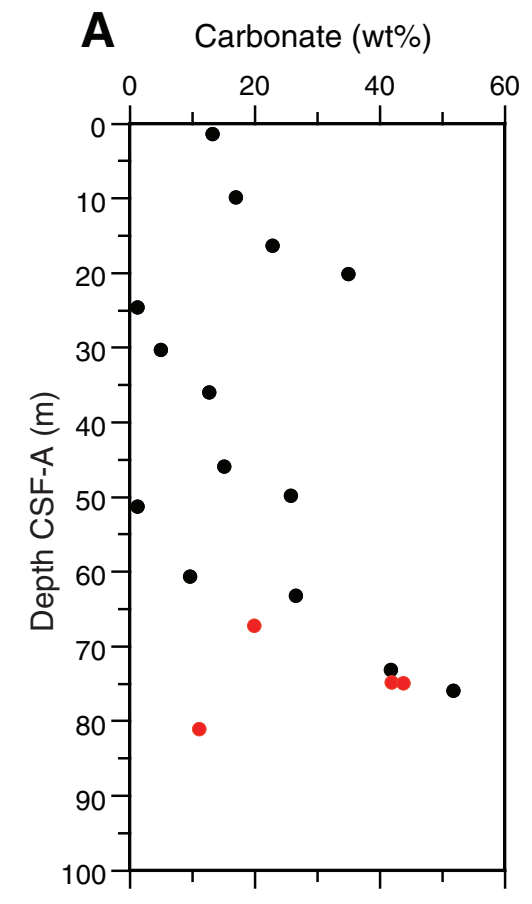

B Total carbon (wt\%)

C Total nitrogen (wt\%)
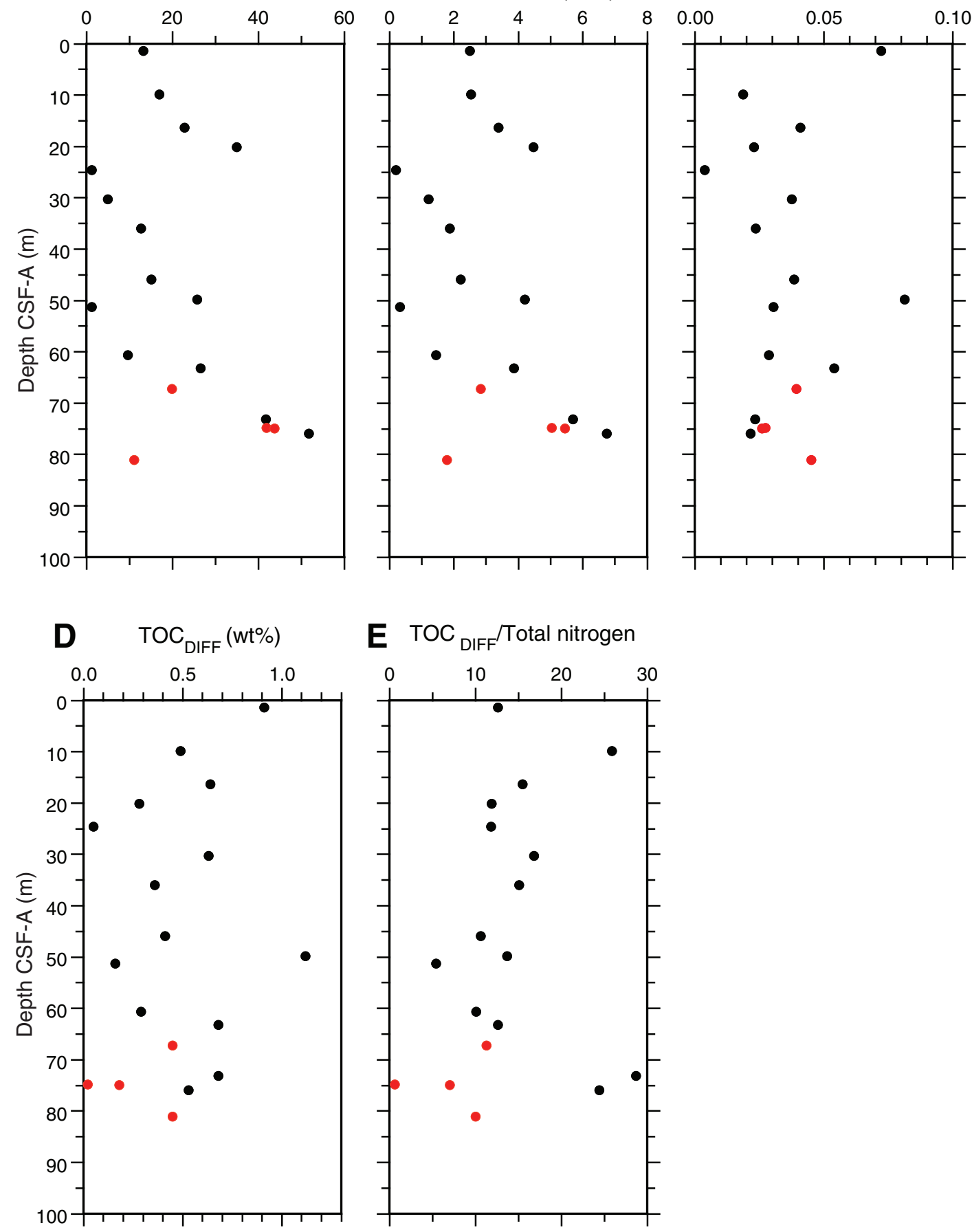

E TOC $_{\mathrm{DIFF}} /$ Total nitrogen

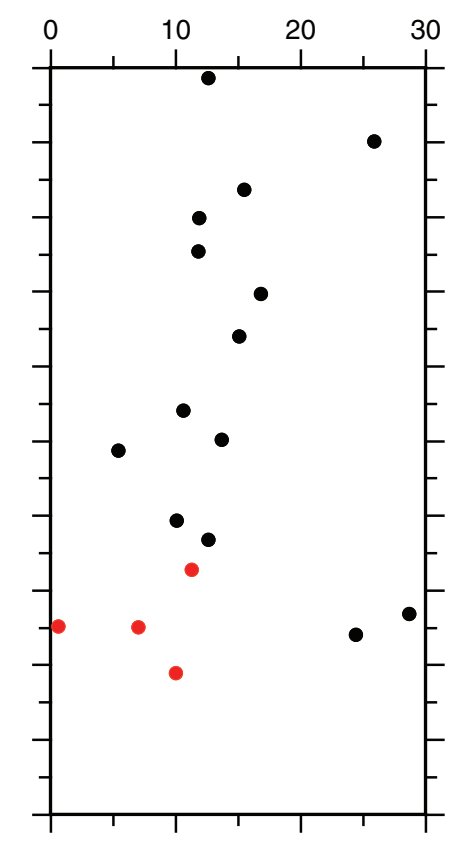


Figure F29. Plots of ionic constituents of interstitial water vs. depth, Holes U1354A (red) and U1354C (blue). A. Salinity. B. Chloride. C. Sodium. D. pH. SW = IAPSO seawater values.

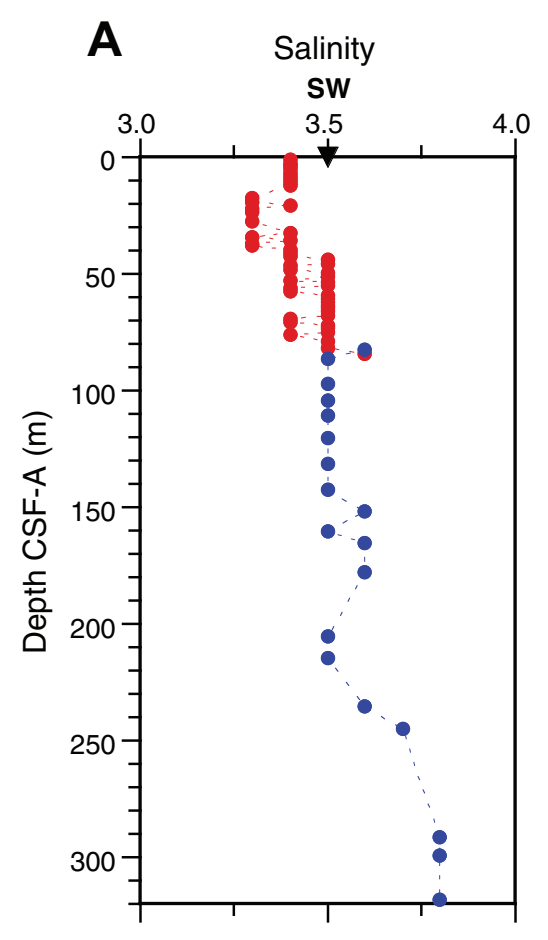

B Chloride (mM)
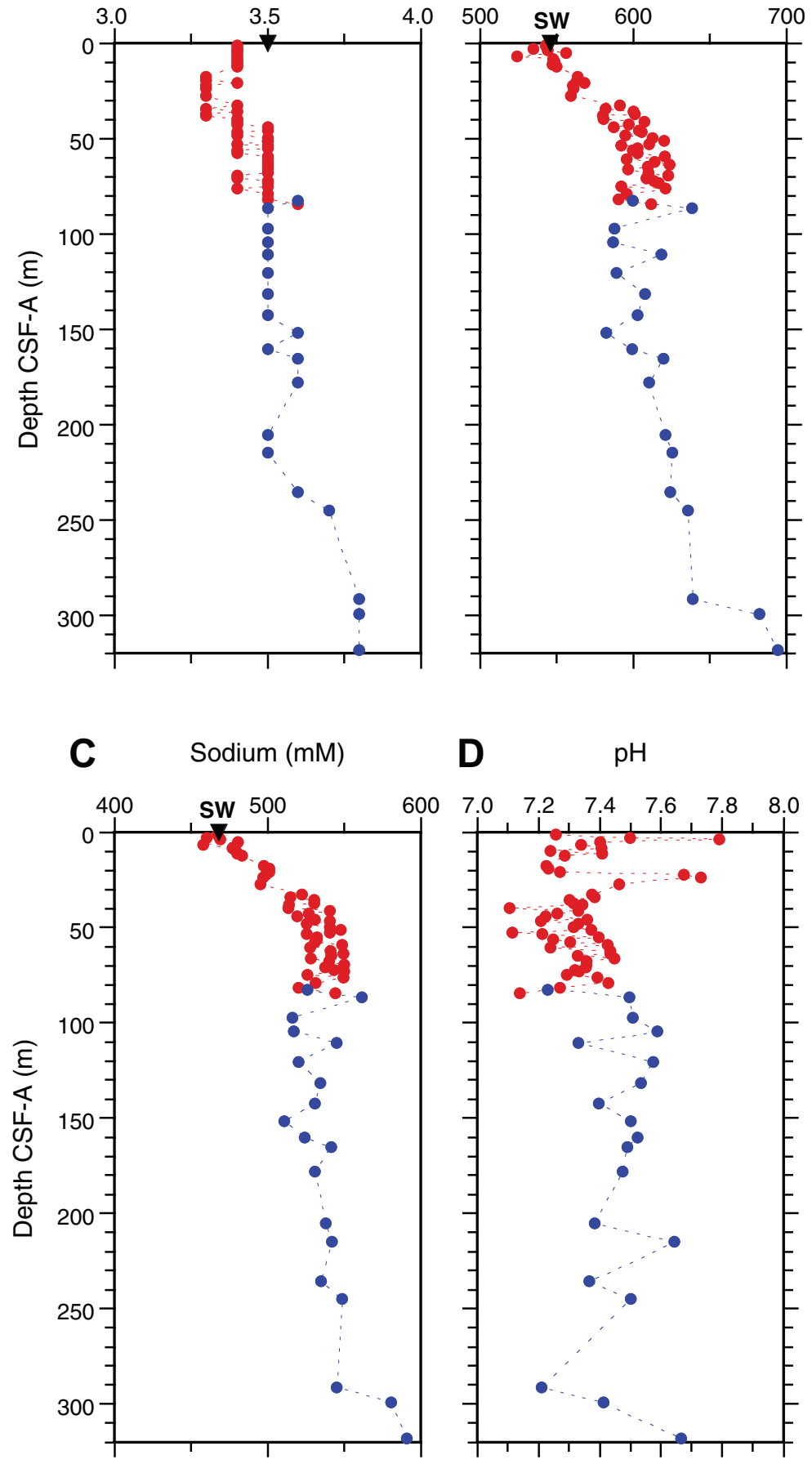

D $\mathrm{pH}$

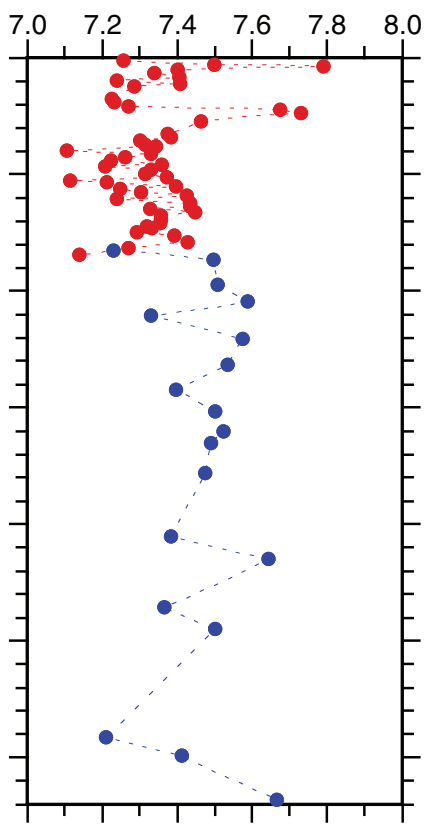


Figure F30. Plots of ionic constituents of interstitial water vs. depth, Holes U1354A (red) and U1354C (blue). A. Calcium. B. Magnesium. C. Magnesium/calcium ratio. D. Strontium. E. Strontium/calcium ratio. F. Alkalinity. SW = IAPSO seawater values.
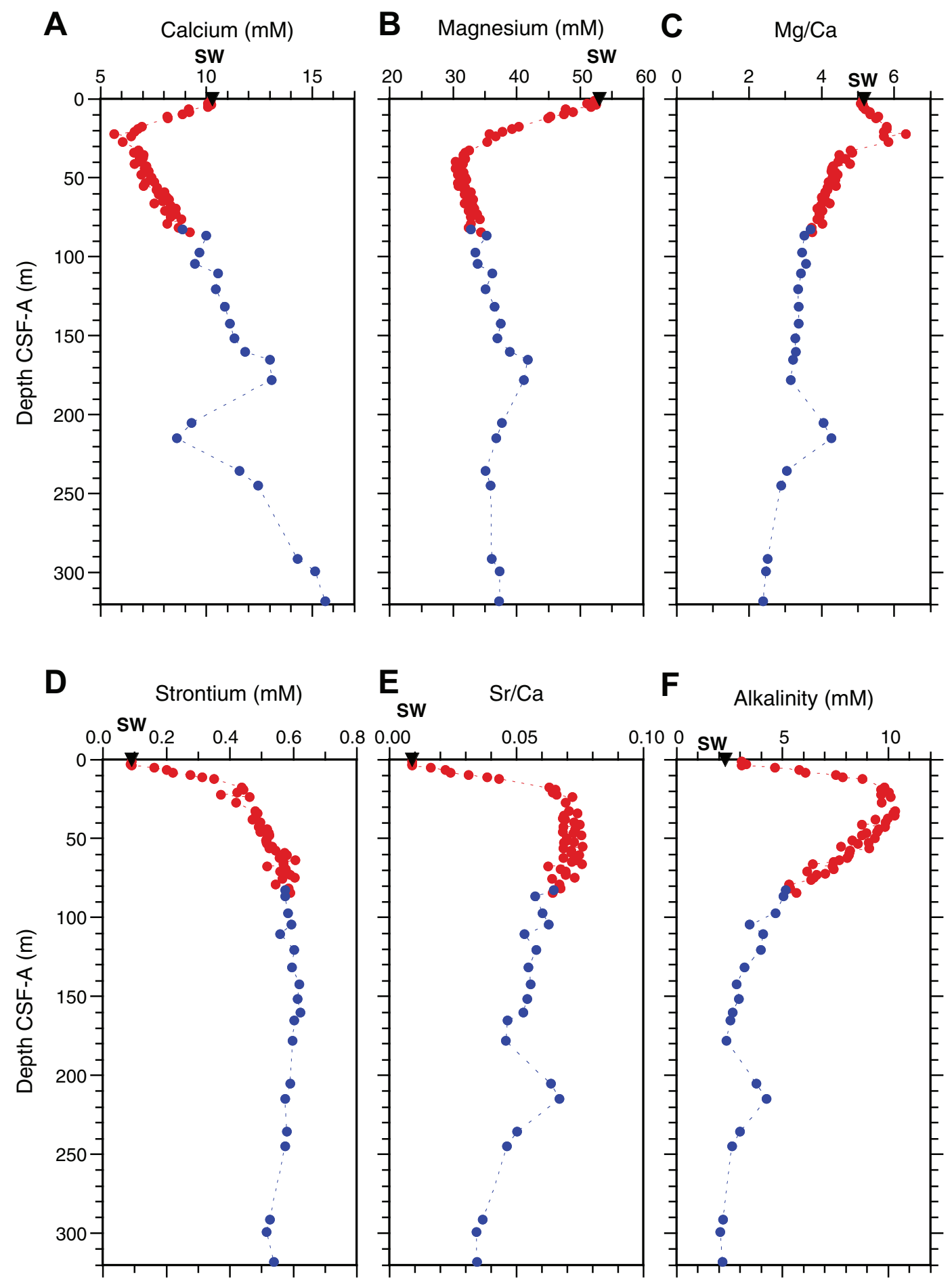
Figure F31. Plots of ionic constituents of interstitial water vs. depth, Holes U1354A (red) and U1354C (blue). A. Sulfate. B. Phosphate. SW = IAPSO seawater values.

\section{A}

B

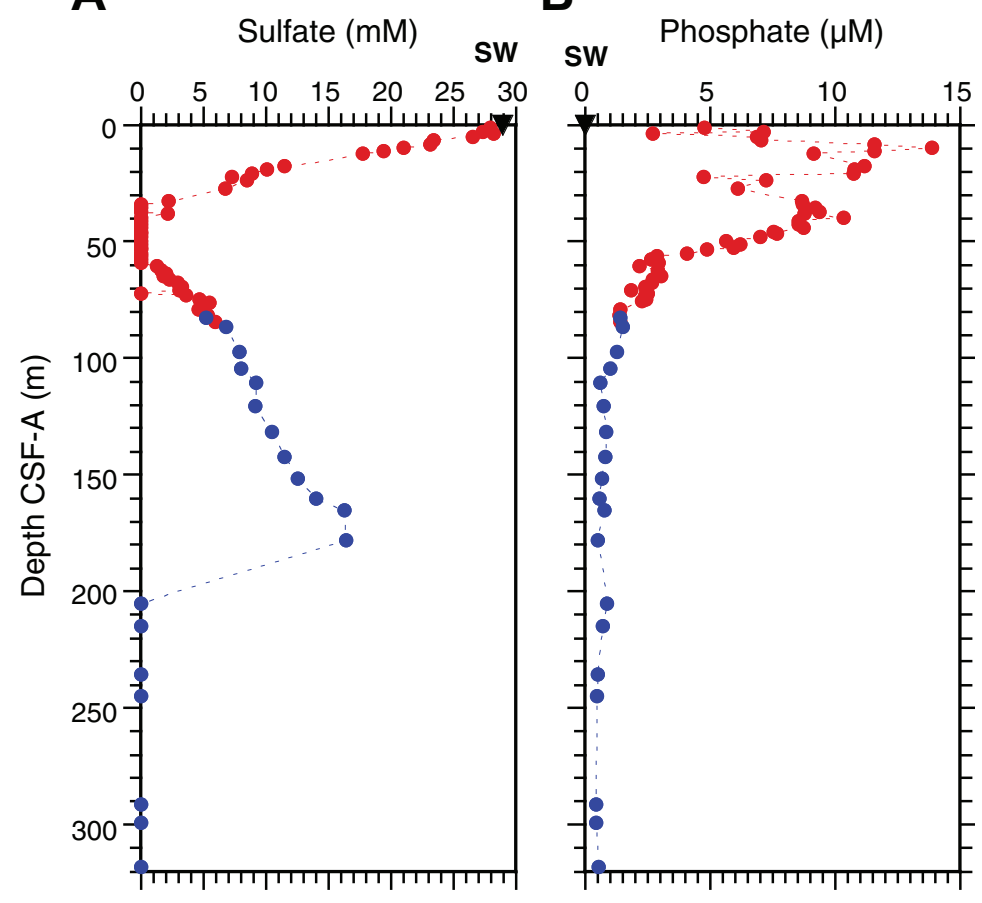


Figure F32. Plots of ionic constituents of interstitial water vs. depth, Holes U1354A (red) and U1354C (blue). A. Potassium. B. Barium. C. Lithium. D. Silicon from inductively coupled plasma spectroscopy (ICP). SW = IAPSO seawater values.

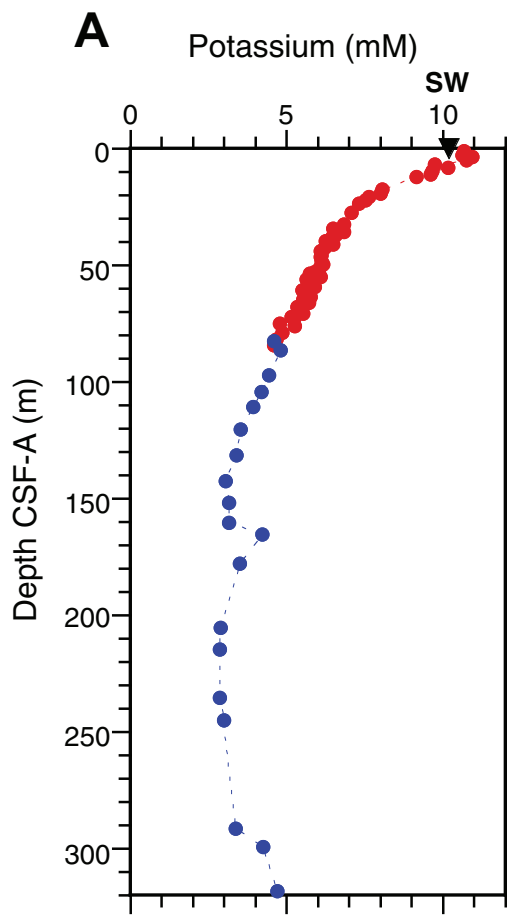

B sw Barium $(\mu \mathrm{M})$
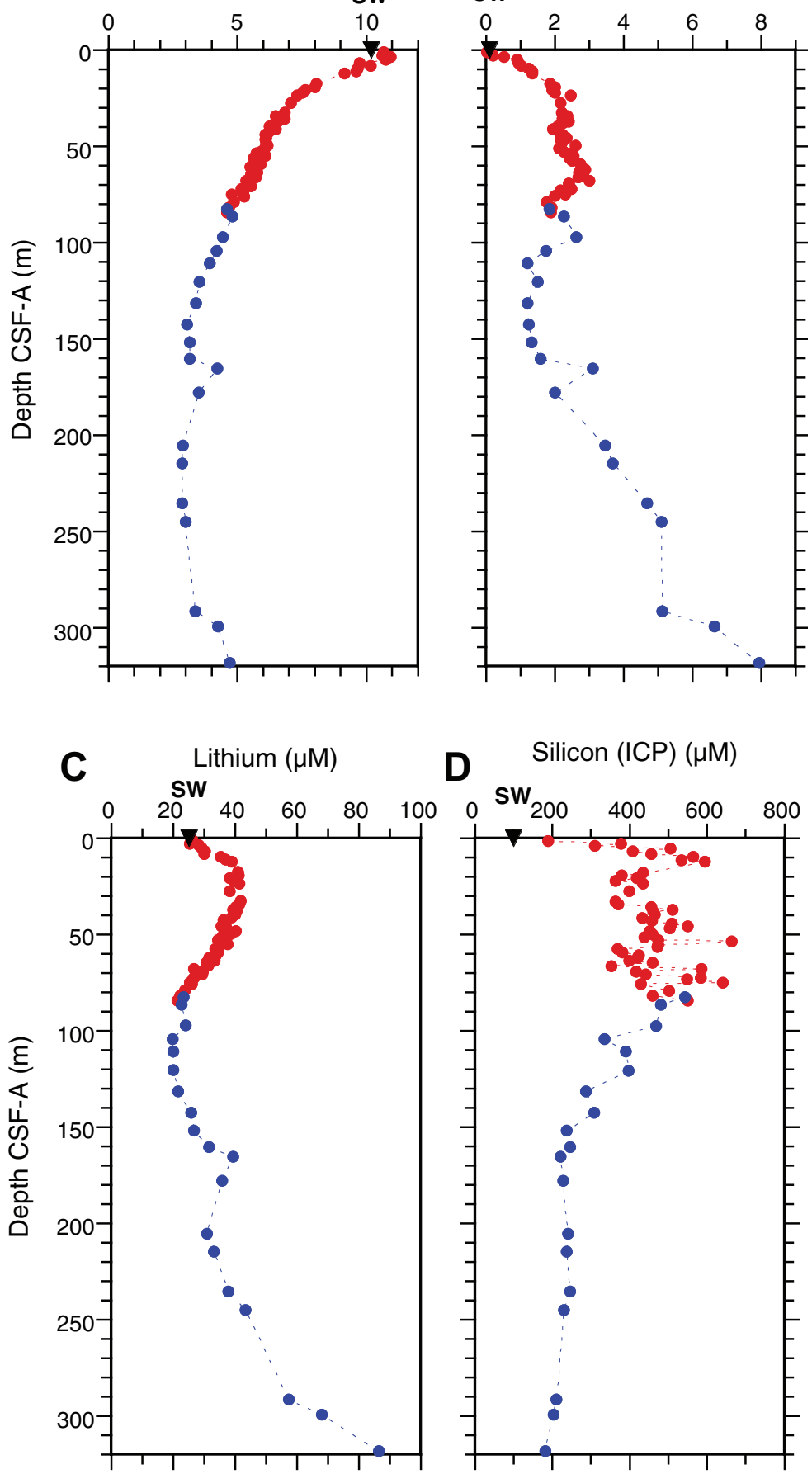

D Silicon (ICP) $(\mu \mathrm{M})$

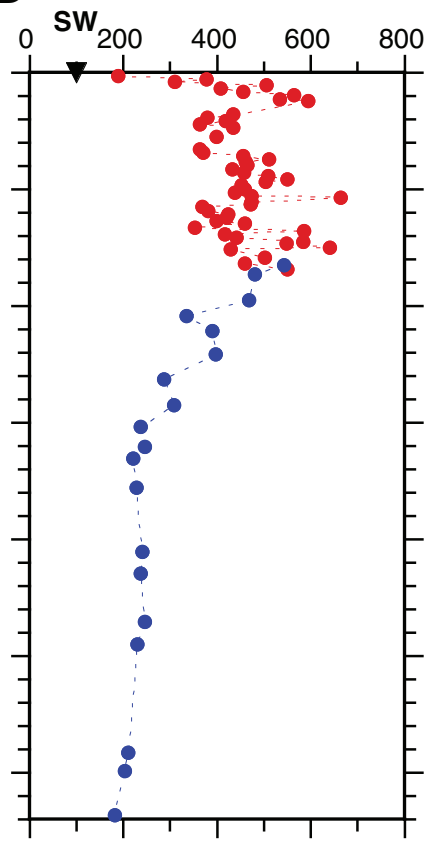


Figure F33. Plots of ionic constituents of interstitial water vs. depth, Holes U1354A (red) and U1354C (blue). A. Boron. B. Iron. C. Manganese. SW = IAPSO seawater values.
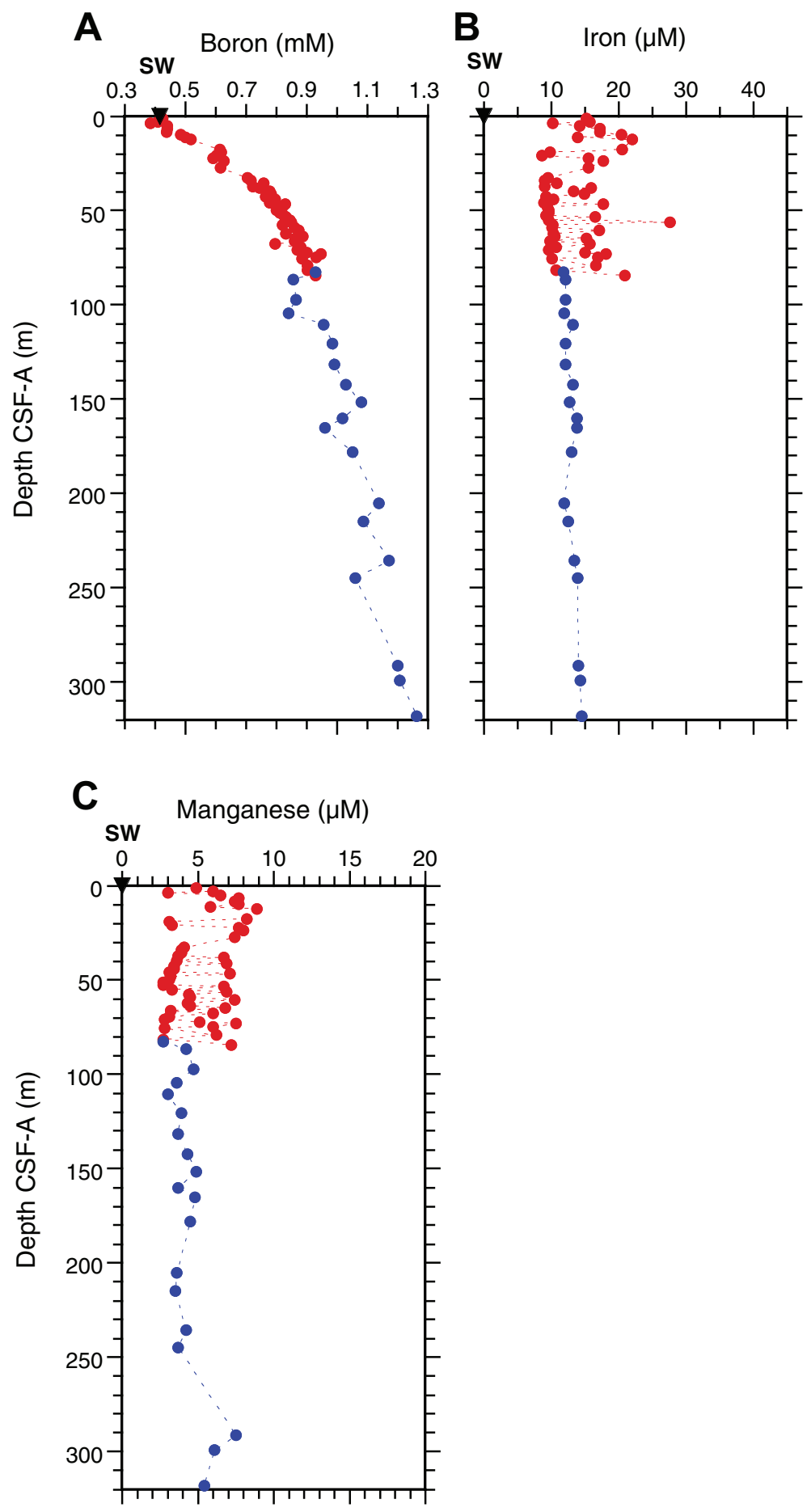
Figure F34. Uppermost $180 \mathrm{~m}$ depth profiles for Holes U1354A (open symbols) and U1354C (solid symbols). A. Alkalinity, sulfate, calcium, magnesium, and methane. B. Magnesium/calcium ratio. C. Barium. D. Phosphate.

A Alkalinity, sulfate, calcium, magnesium (mM) B and methane (ppmv)

\section{B} $\mathrm{Mg} / \mathrm{Ca}$

C Barium $(\mu \mathrm{M}) \quad$ Phosphate $(\mu \mathrm{M})$
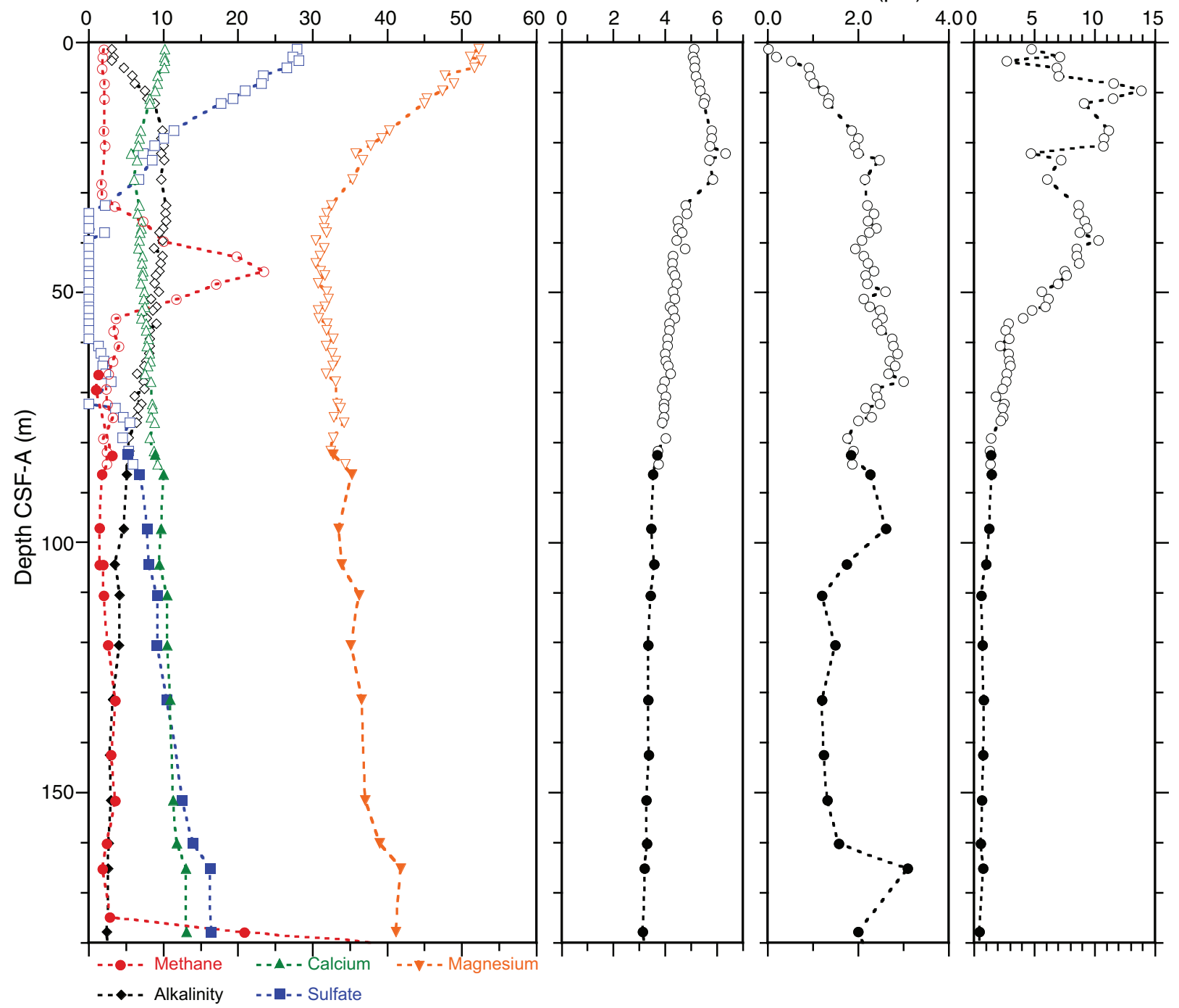
Figure F35. Plot of alkalinity added plus calcium and magnesium removed vs. sulfate removed, showing stoichiometry of the sulfate-reduction zone for samples shallower than $41 \mathrm{~m}$ (black) and samples between 61 and $178 \mathrm{~m}$ (red). Equations for methane oxidation (bottom) and organic matter oxidation (top) are shown. Data from the shallow zone plot close to the 1.3:1 line (correlation line and equation shown in black), and data from the deeper zone plot close to the 1:1 line (correlation line and equation shown in red).

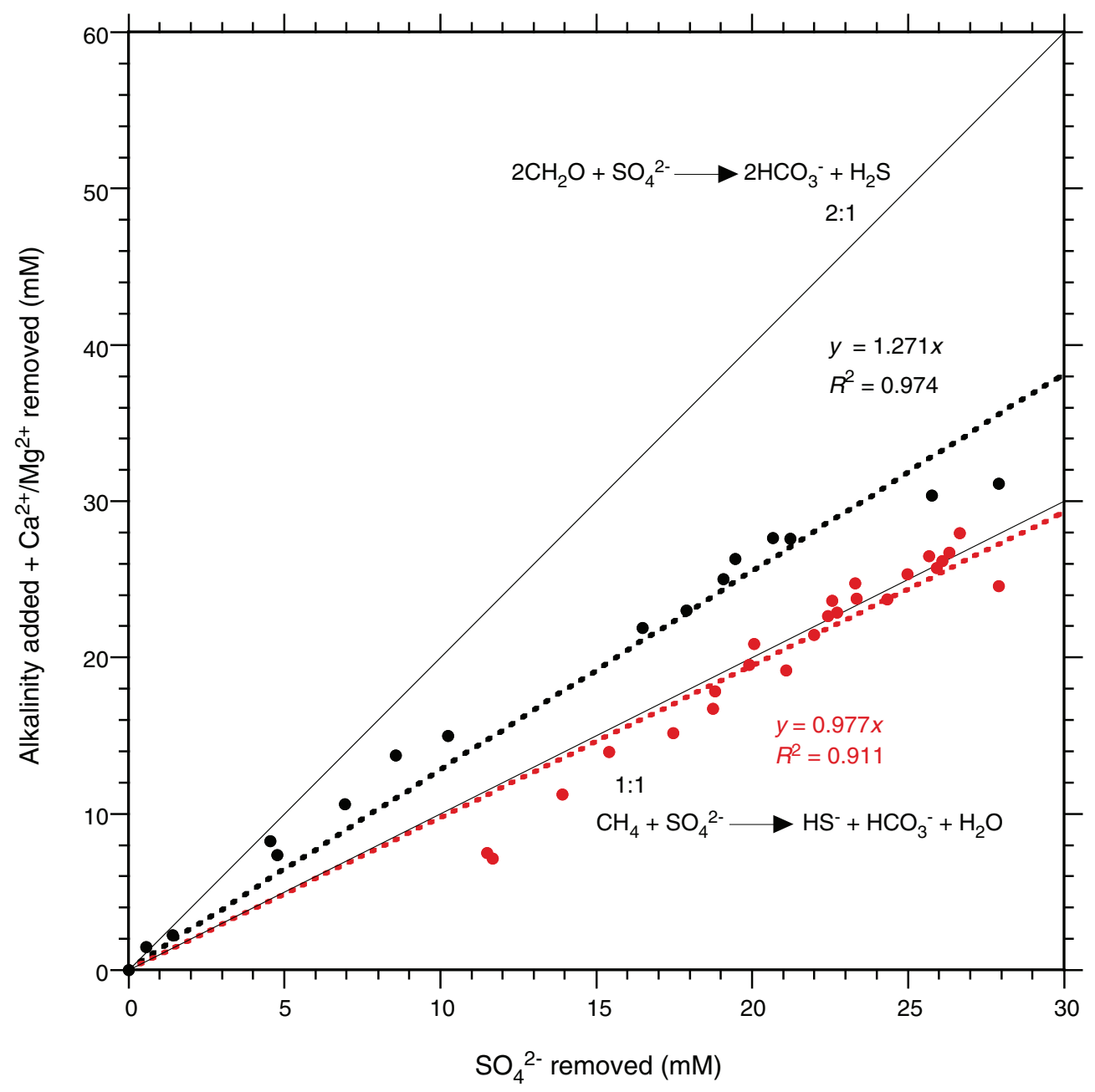


Figure F36. A. Temperature data for Site U1354. During the time interval $t_{\mathrm{i}}$ to $t_{\mathrm{f}}$ (open circles), an exponential decrease in temperature is expected and used to estimate ambient temperature. Two temperature measurements were made in Cores 317-U1354C-14X and 16X, but the results were poor. See Table T20 for values.

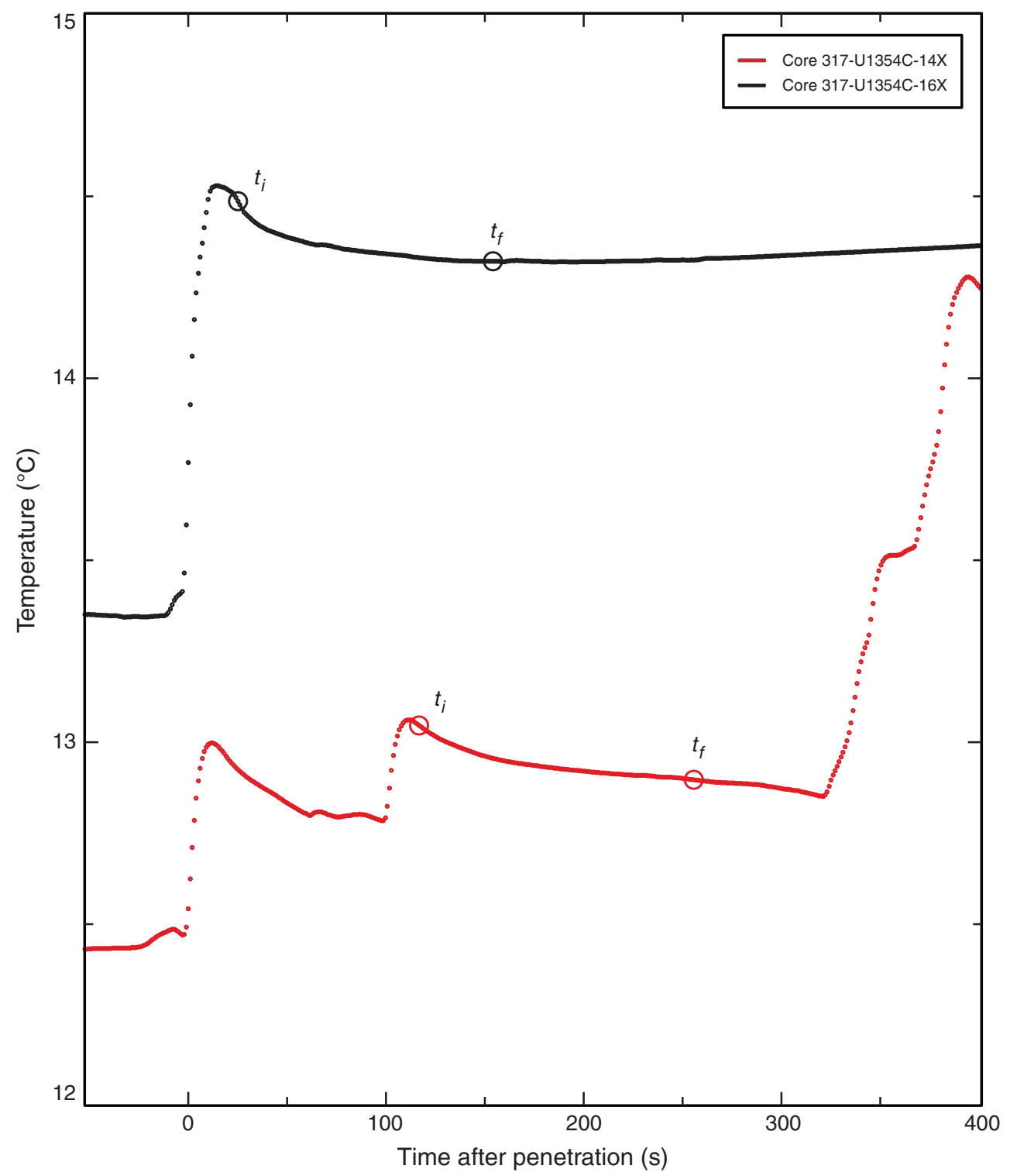


Figure F37. Thermal conductivity for Site U1354 vs. (A) depth, (B) porosity, and (C) bulk density. Thermal conductivity generally exhibits a negative relationship with porosity and a positive relationship with bulk density. There is no distinguishable correlation with lithology.

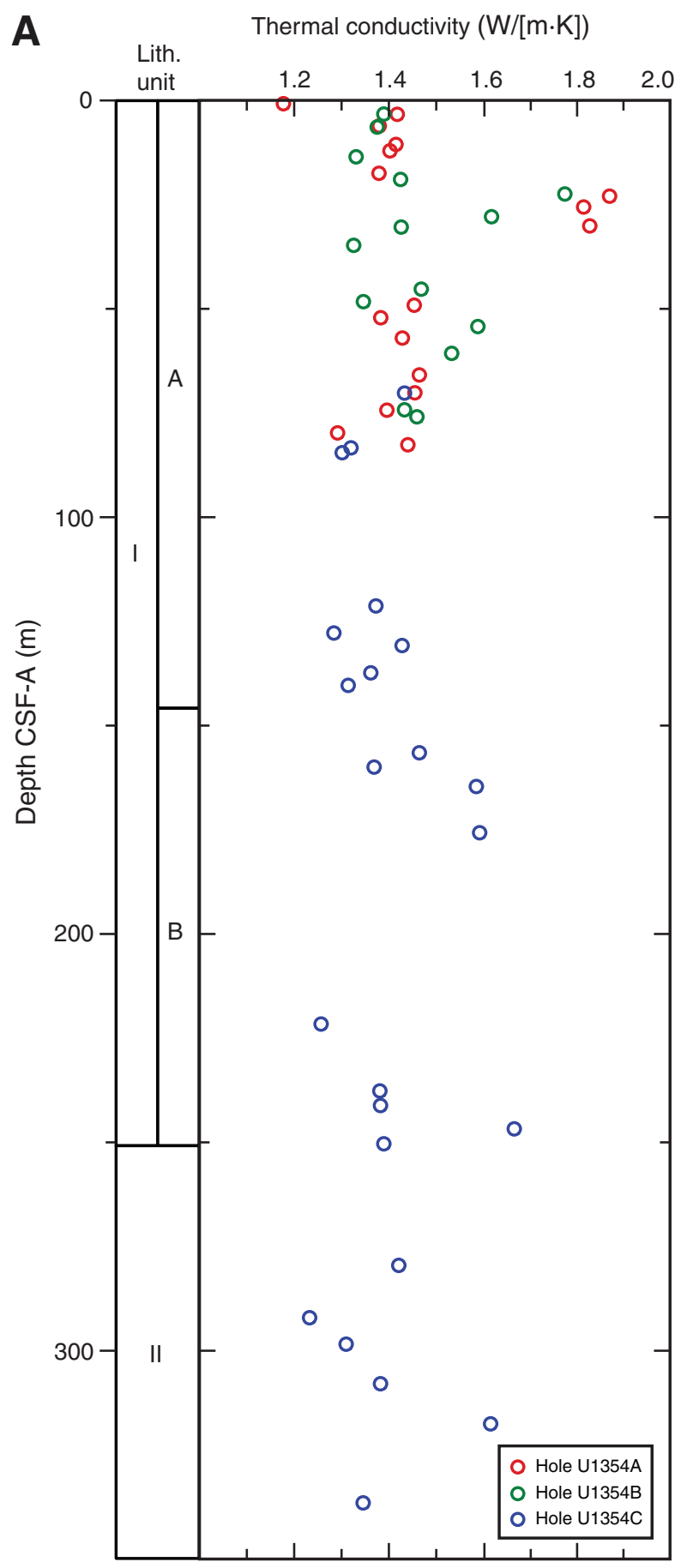

B

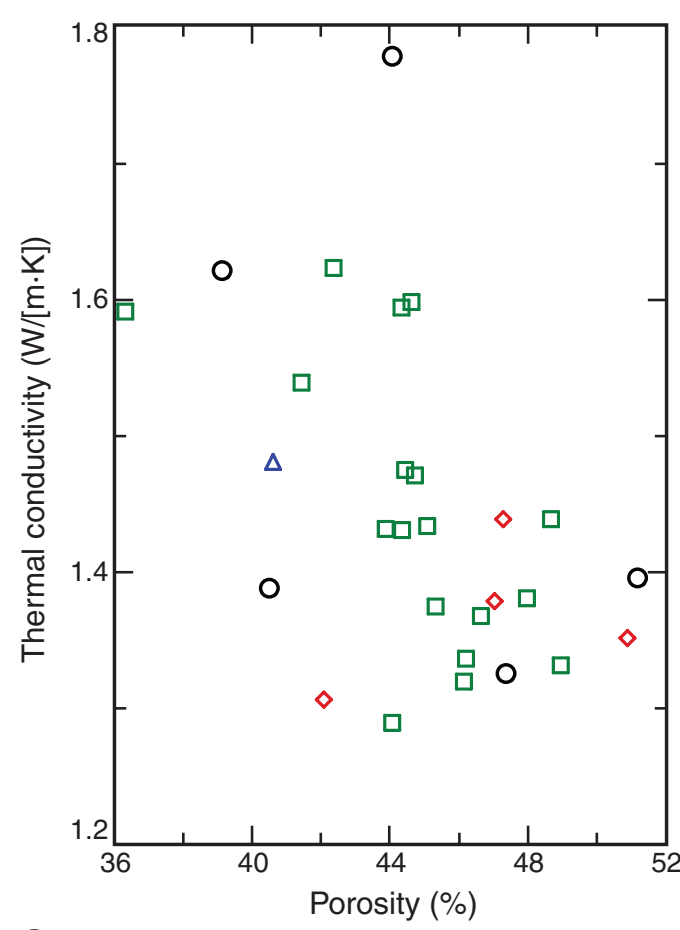

C

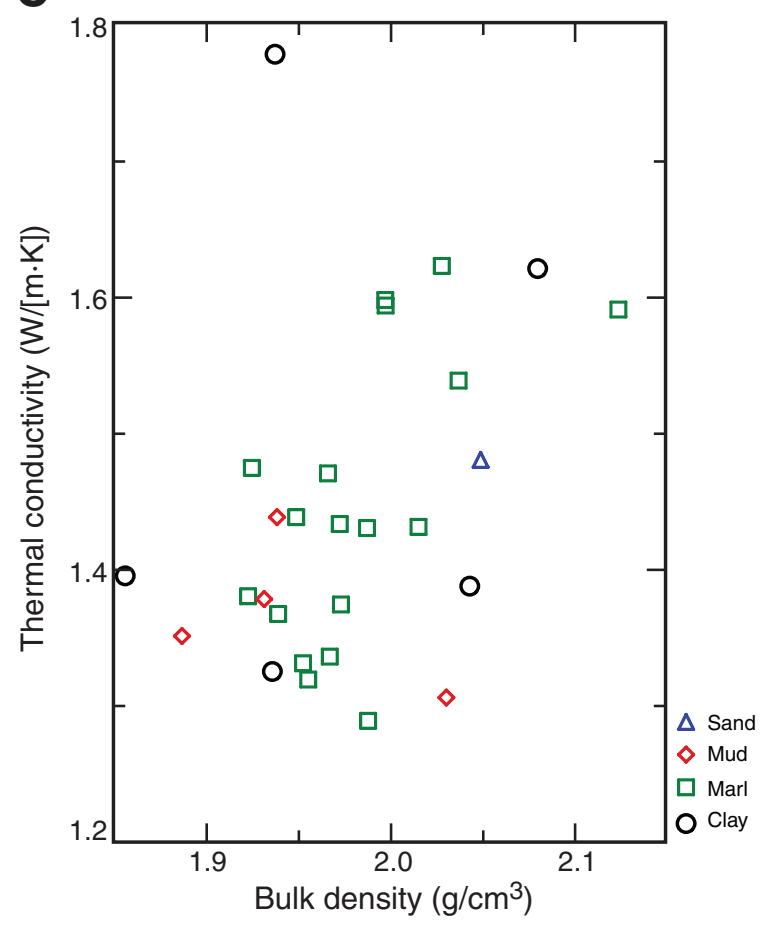


Figure F38. Summary of logs recorded by the "sonic combo" tool string in Hole U1354C and comparison to physical property data measured on recovered cores. Resistivity-derived porosity and density were calculated from the phasor deep induction $\log (\mathrm{IDPH})$. NGR = natural gamma radiation core measurements, IMPH = phasor medium induction $\log , \mathrm{MAD}=$ moisture and density core data, GRA = gamma ray attenuation bulk density core measurements.

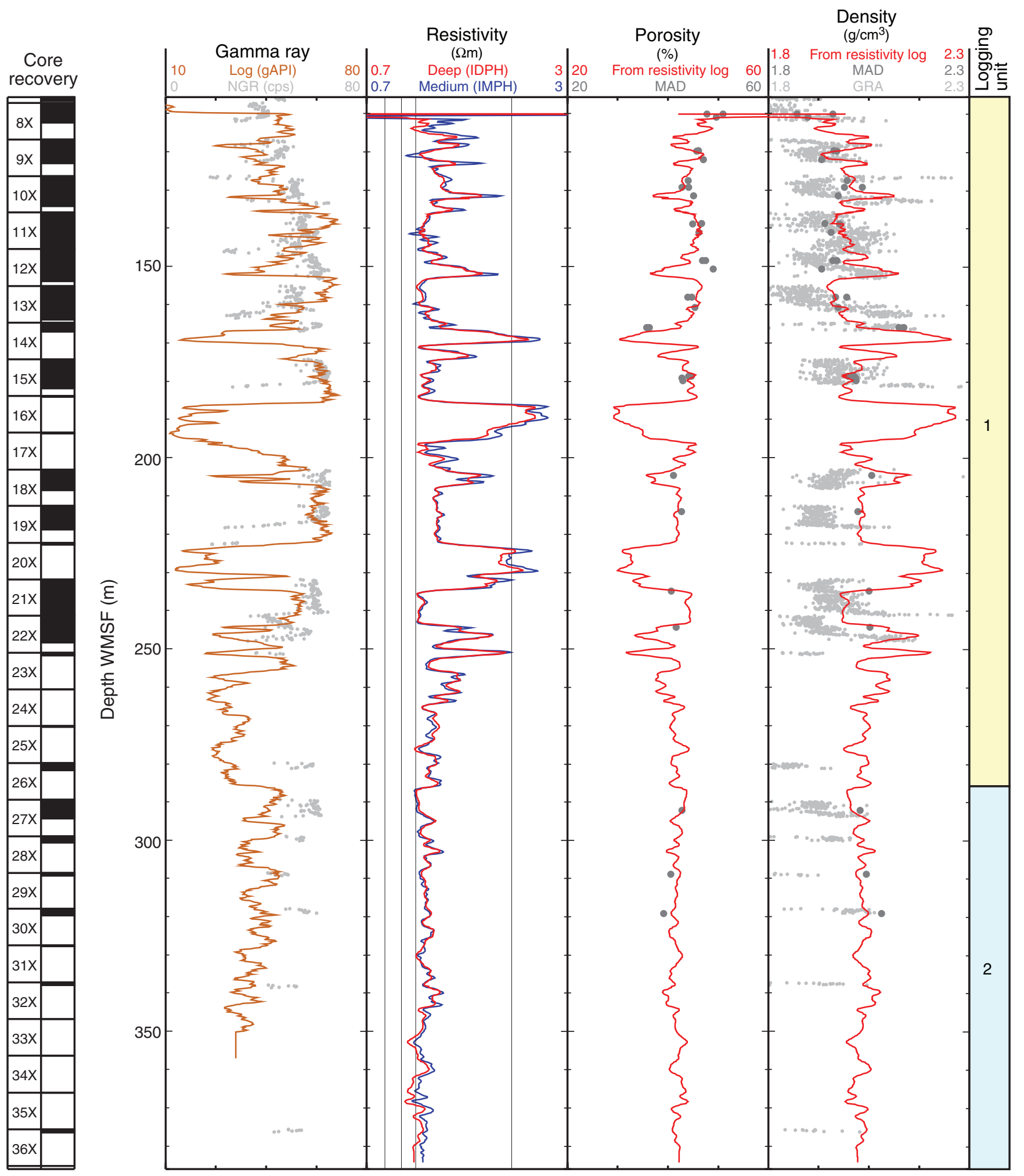


Figure F39. Summary of logs recorded by the "sonic combo" tool string in Hole U1354C. Sonic waveform (WF) amplitude is shown as an indicator of data quality. High waveform coherence, shown in red in the two velocity tracks, is a measure of the reliability of the slowness/time coherence algorithm used to derive compressional $\left(V_{\mathrm{P}}\right)$ and shear $\left(V_{\mathrm{S}}\right)$ velocities from the monopole and lower dipole sonic waveforms, respectively.

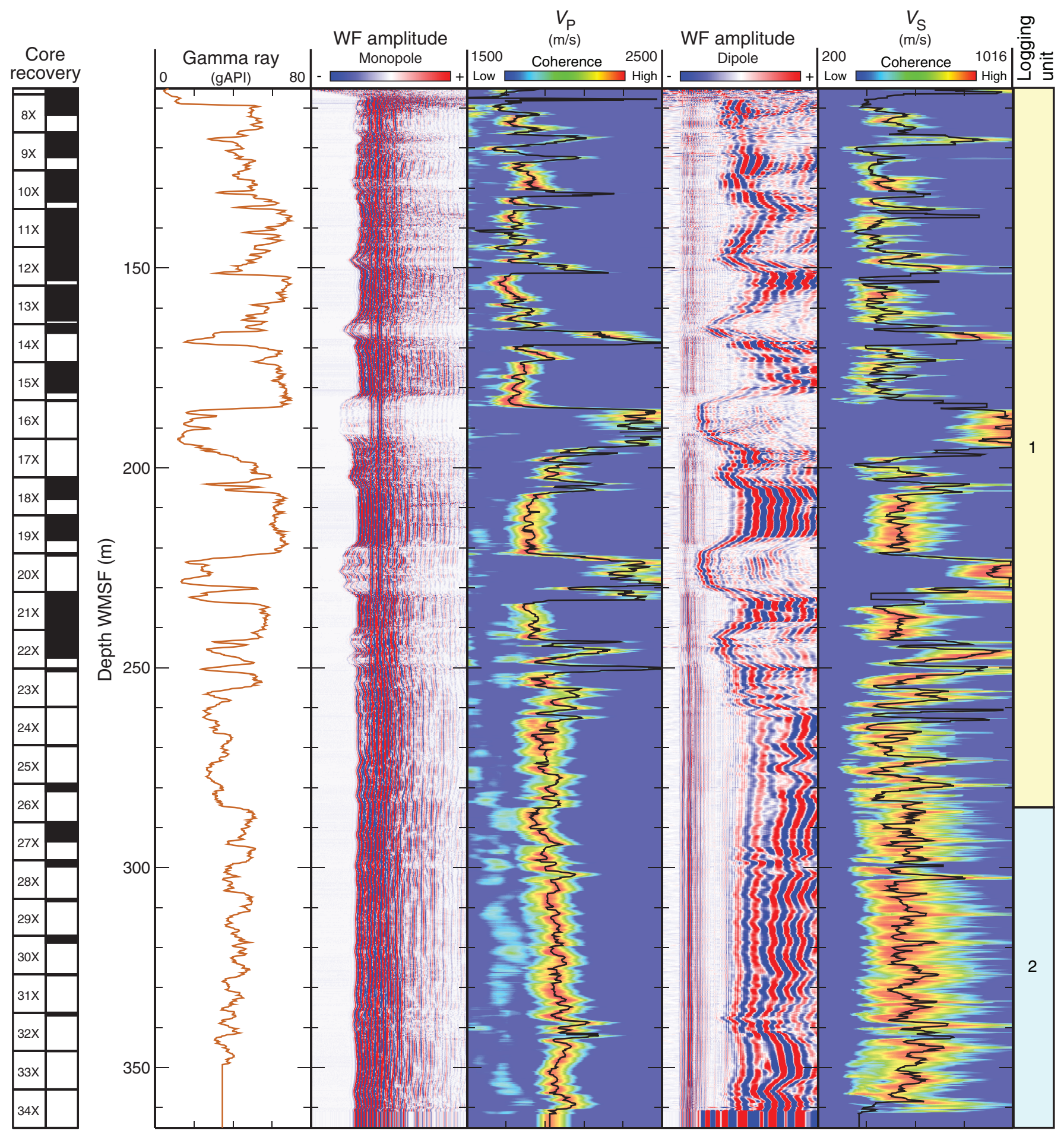


Figure F40. Summary of spectral natural gamma ray measurements in Hole U1354C. SGR = total gamma ray, CGR = computed gamma ray (gamma ray without uranium contribution). The CGR and SGR curves define an envelope (colored green), and the area between the two curves shows the contribution of uranium, a common indicator of organic content.

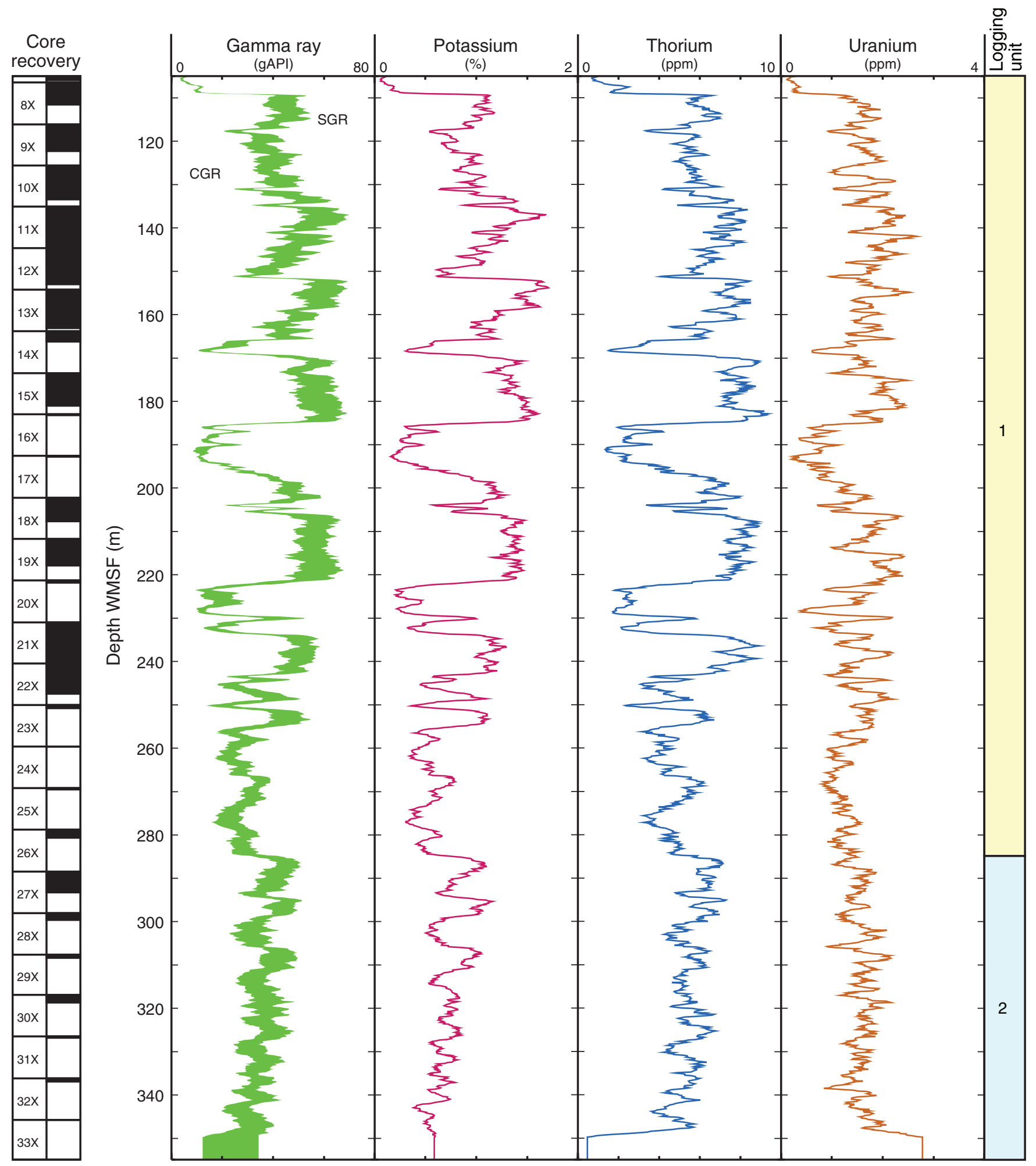


Figure F41. Comparison of some of the main logs recorded during the downhole and uphole logging passes in Hole U1354C. All data sets show a good agreement between the two passes, indicating the reliability of the various measurements.

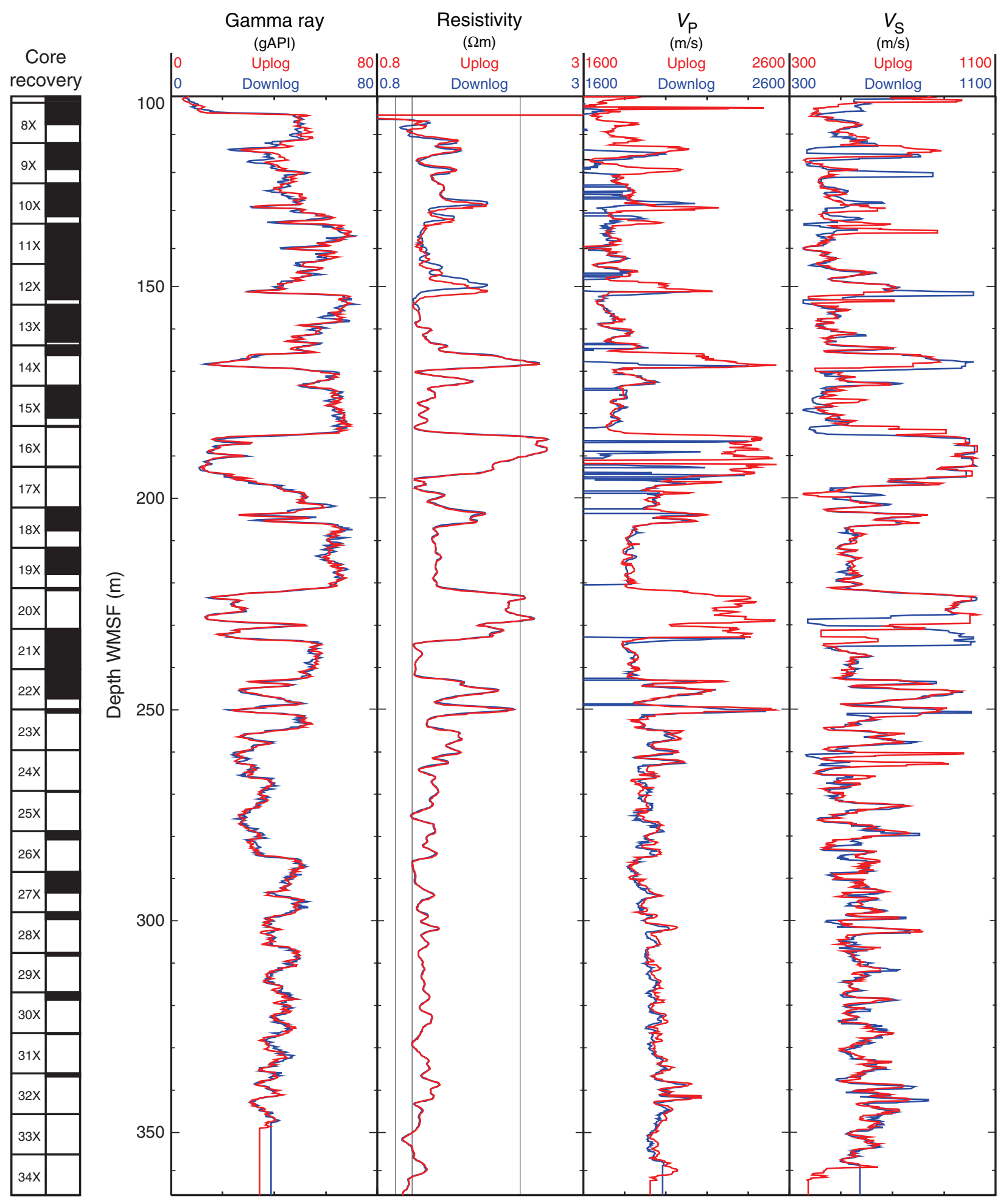


Figure F42. Comparison of synthetic seismogram calculated from density and $V_{\mathrm{p}}$ logs in Hole U1354C with EW00-01 Line 66 across Site U1354. The gamma ray log is shown as a reference to the other logs and the logging units at this site. Density was computed from the resistivity log using Archie's equation and MAD grain density. Dashed lines in seismic panel indicate seismic sequence boundaries U9-U13. See "Downhole logging" for details. $\mathrm{IDPH}=$ phasor deep induction $\log , \mathrm{CDP}=$ common depth point. (Figure shown on next page.) 

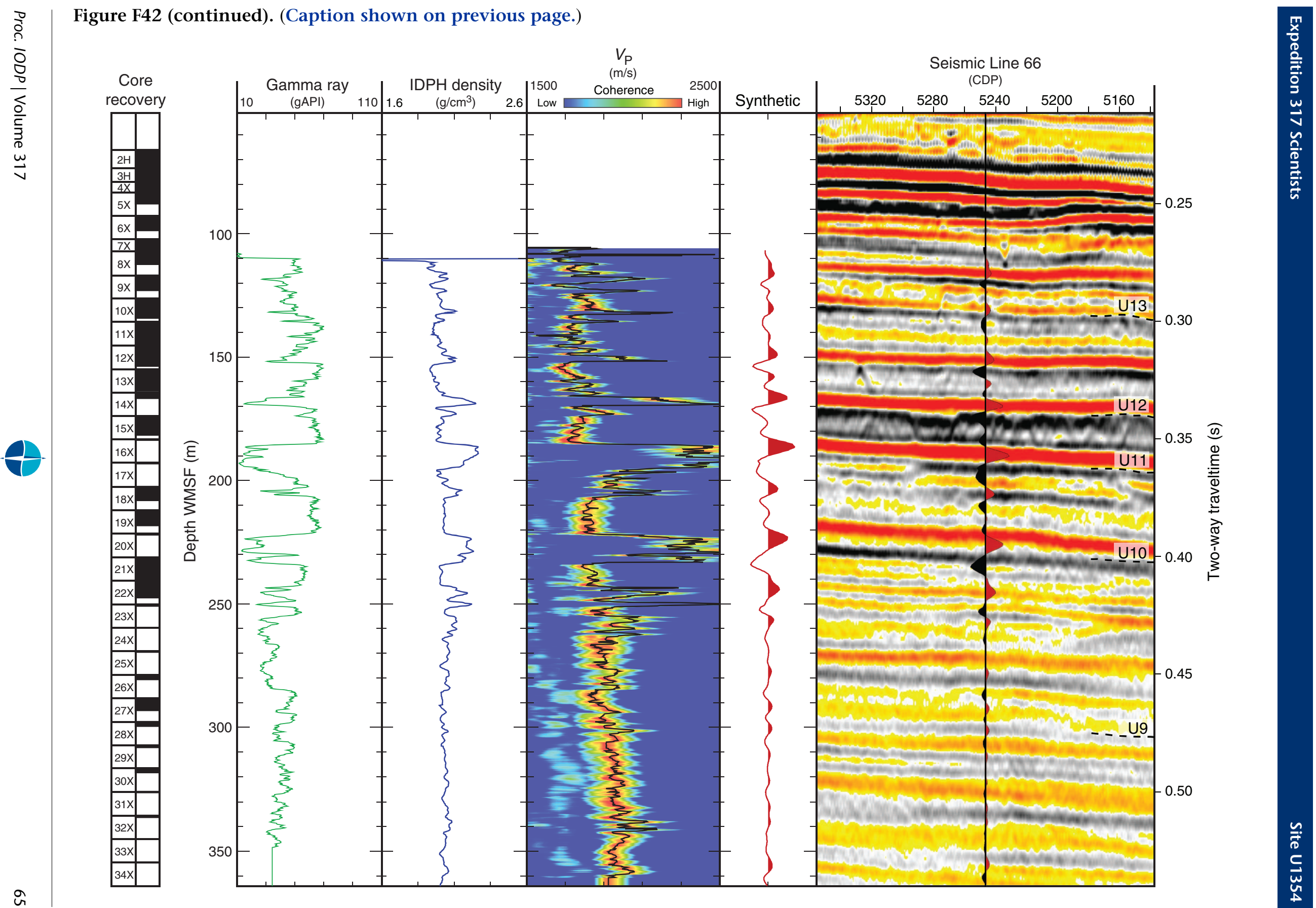
Figure F43. Depth-adjusted records of magnetic susceptibility and natural gamma radiation (NGR) data for Holes U1354A, U1354B, and U1354C. Gaps in the records represent positions where depth adjustments have been made to correlate key features. Dashed line = Brunhes/Matuyama boundary, solid lines = key correlative horizons.

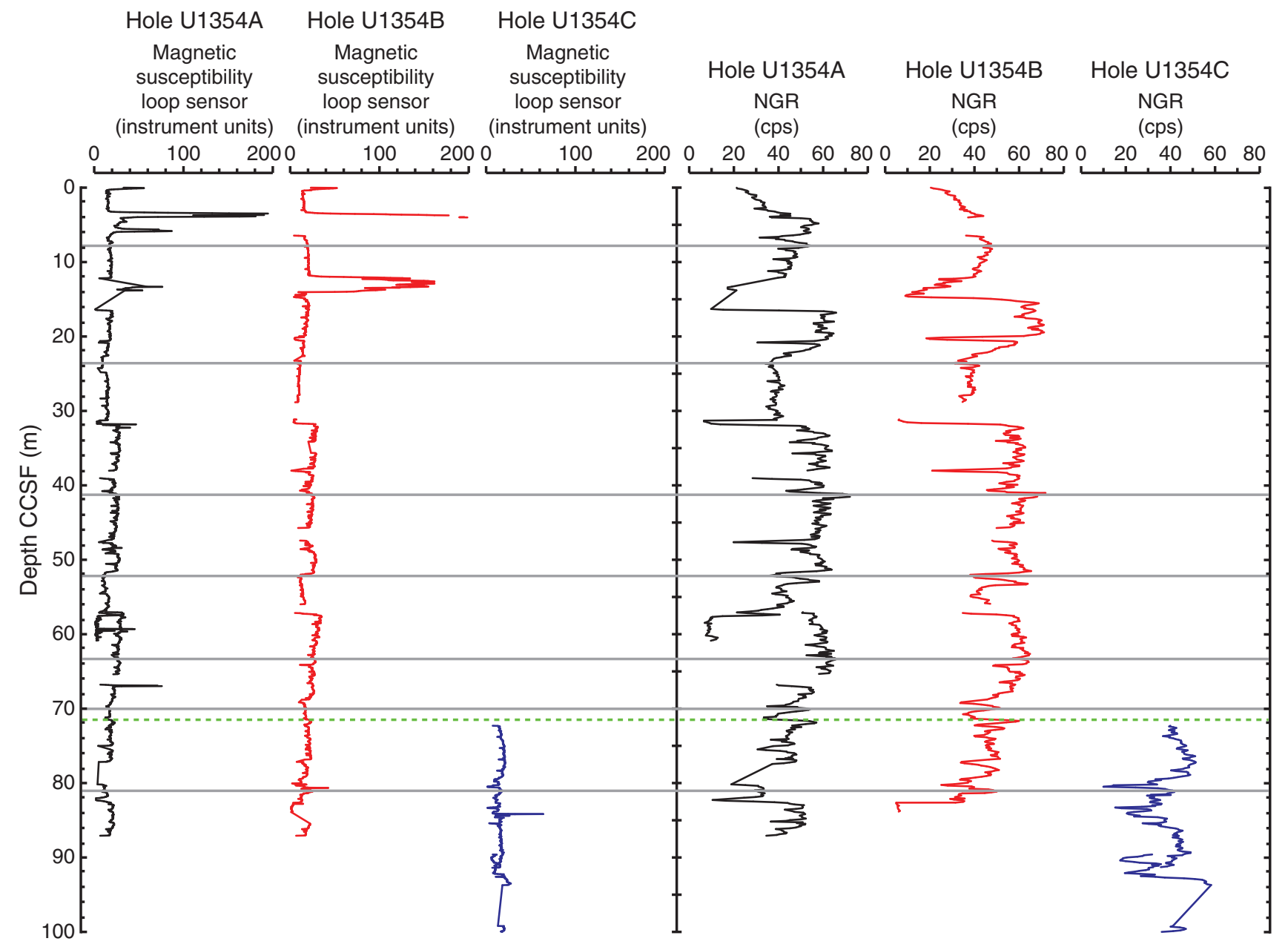


Table T1. Coring summary, Site U1354. (See table notes.) (Continued on next page.)

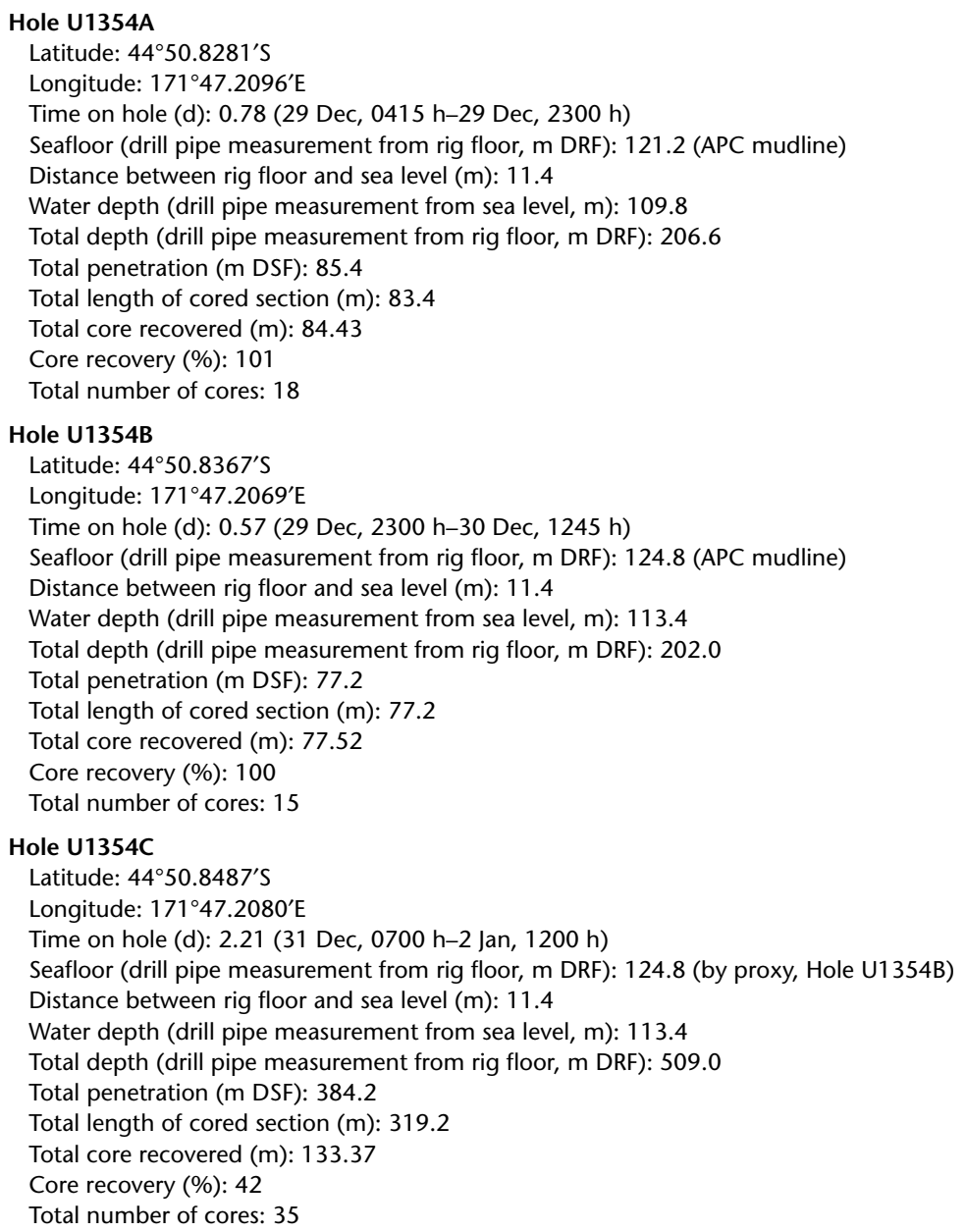

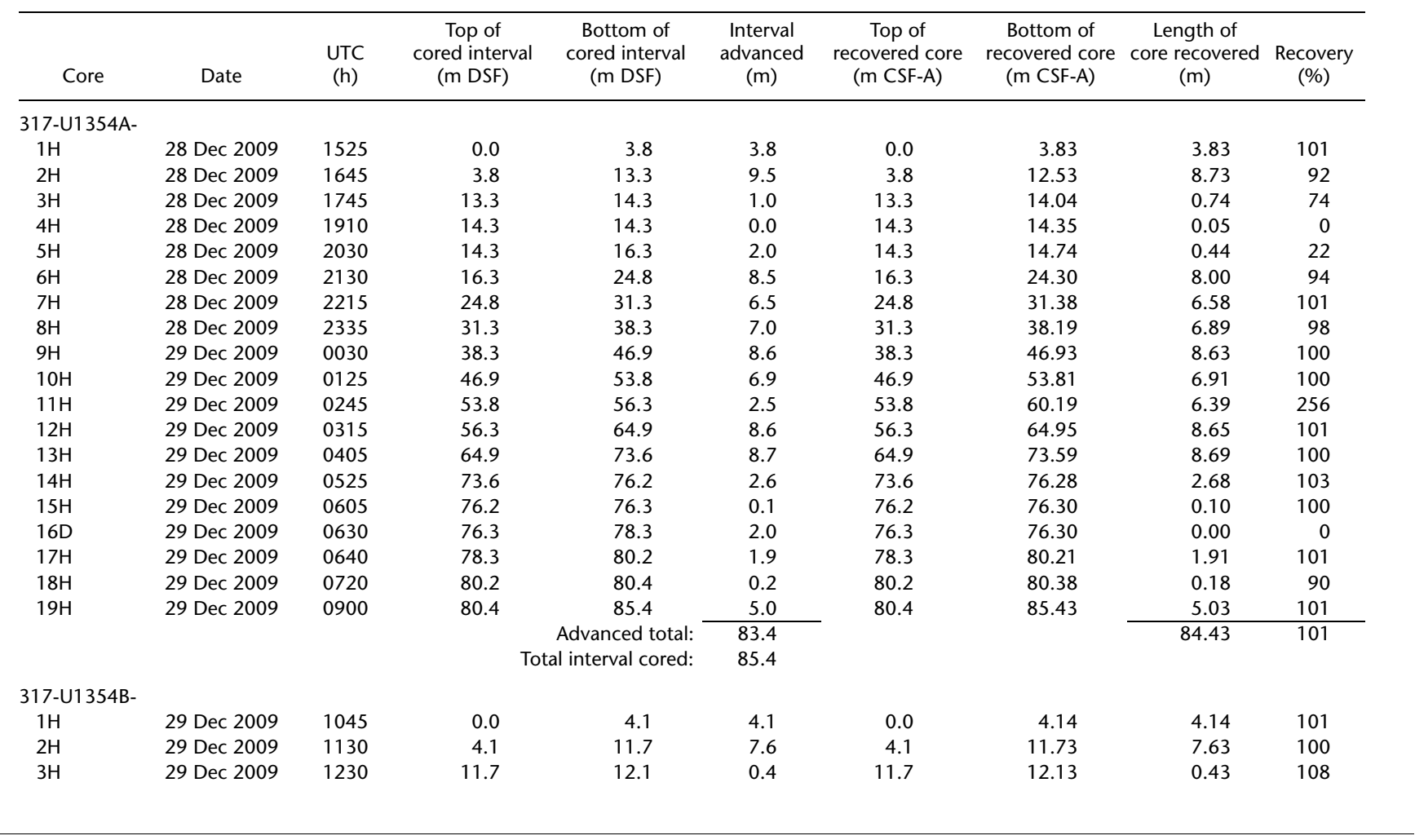


Table T1 (continued).

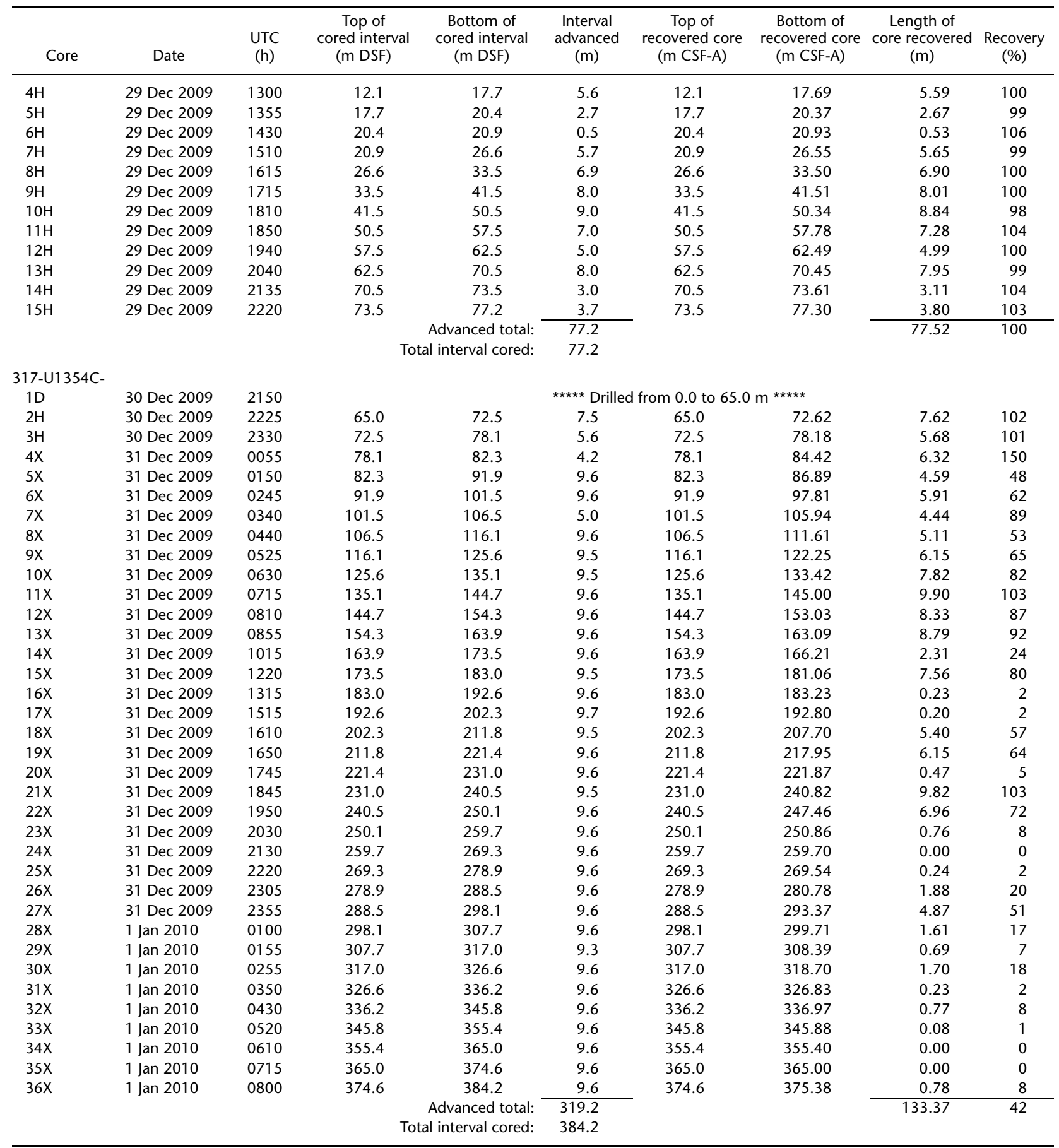

Notes: APC = advanced piston corer. DRF = drilling depth below rig floor, DSF = drilling depth below seafloor, CSF-A = core depth below seafloor. UTC $=$ Universal Time Coordinated. 
Table T2. Lithostratigraphic summary, Site U1354. (See table note.)

\begin{tabular}{|c|c|c|c|c|}
\hline $\begin{array}{l}\text { Lith. } \\
\text { unit }\end{array}$ & Age & Interval & $\begin{array}{l}\text { Depth } \\
(\mathrm{m})\end{array}$ & $\begin{array}{c}\text { Lithologies } \\
\text { (decreasing order of importance) }\end{array}$ \\
\hline IA & Holocene to early Pliocene & $\begin{array}{l}317- \\
\text { U1354A-1 } 1 \mathrm{H} \text { through } 19 \mathrm{H} \\
\text { U1354B-1H through } 15 \mathrm{H} \\
\text { U1354C-1 } \mathrm{H} \text { to } 12 \mathrm{X}-1,110 \mathrm{~cm}\end{array}$ & $\begin{array}{c}85.43 \text { TD } \\
77.52 \text { TD } \\
0-145.80\end{array}$ & Mud, sandy mud, marl, shell hash, very fine sand, marl, muddy sand \\
\hline IB & early Pliocene to mid-Pliocene & $\mathrm{U} 1354 \mathrm{C}-12 \mathrm{X}-1,110 \mathrm{~cm}$, to $23 \mathrm{X}-\mathrm{CC}, 20 \mathrm{~cm}$ & $145.80-250.81$ & Mud, marl, very fine sand, sandy mud, muddy sand, clay \\
\hline II & early Pliocene & U1354C-23X-CC, $20 \mathrm{~cm}$, through 36X-CC & $250.81-375.38$ & Mud, sandy mud \\
\hline
\end{tabular}

Note: $T D=$ total depth

Table T3. Lithologic surfaces and their interpretation, Site U1354. (See table notes.)

\begin{tabular}{|c|c|c|c|c|c|c|c|}
\hline $\begin{array}{l}\text { Lithologic } \\
\text { surface }\end{array}$ & $\begin{array}{l}\text { Hole, core, section, } \\
\text { interval }(\mathrm{cm})\end{array}$ & $\begin{array}{c}\text { Depth } \\
\text { CSF-A (m) }\end{array}$ & Overlying lithology & Nature of significant surface & $\begin{array}{l}\text { Seismic } \\
\text { sequence } \\
\text { boundary }\end{array}$ & $\begin{array}{l}\text { Predicted } \\
\text { depth } \\
(\mathrm{m})\end{array}$ & $\begin{array}{l}\text { Preliminary biostratigraphy } \\
\text { (Ma) }\end{array}$ \\
\hline & 317- & & & & & & \\
\hline U1354A-S1 & U1354A-3H-CC, 16 & 13.99 & Shelly mud & Top contact; basal not recovered & U19 & 11 & $<0.29(\mathrm{CN})$, possibly <0.1 (CN) \\
\hline U1354B-S1 & U1354B-2H-6, 54 & 11.68 & Fining-upward shelly sand & Basal not recovered & U19 & 11 & \\
\hline U1354A-S2 & U1354A-6H-5, 45 & 22.63 & Sand & Possible top contact; liquefied sand & U18 & 22 & $<0.29(\mathrm{CN})$, possibly $<0.1(\mathrm{CN})$ \\
\hline U1354B-S2 & U1354B-7H-1, 0 & 20.90 & Sand & Possible top contact; liquefied sand & U18 & 22 & \\
\hline U1354A-S3 & U1354A-11H-3, 30 & 56.64 & Shelly mud & Sharp angular dipping contact & U17 & 51 & $0.29-0.44(\mathrm{CN})$ \\
\hline U1354A-S4 & U1354A-13H-4, 20 & 69.60 & Shelly sandy mud & Sharp basal contact; burrowed & U16 & 64 & $0.44-0.91(\mathrm{CN}),>0.78$ at $65-69 \mathrm{~m}$ (B/M boundary) \\
\hline U1354B-S4 & U1354B-13H-2, 80 & 64.80 & $\begin{array}{l}\text { Shelly sandy mud, limestone clast } \\
5 \mathrm{~cm} \text { long }\end{array}$ & Sharp basal contact; burrowed & U16 & 64 & \\
\hline U1354A-S5 & U1354A-17H-2, 85 & 80.15 & Muddy shelly sand fines upward & Contact not recovered & U15 & 79 & $1.26-1.34$ (best age control on this surface for all sites) \\
\hline U1354B-S5 & U1354B-14H-CC, 15 & 73.54 & Muddy shelly sand & Contact not recovered & U15 & 79 & \\
\hline U1354C-S5 & U1354C-3H-3, 110 & 75.39 & Muddy shelly sand & Sharp contact; burrowed & U15 & 79 & \\
\hline U1354C-S5.1 & U1354C-6X-2, 46 & 93.86 & Muddy shelly sand & Sharp contact; burrowed & U14 & 93 & $1.34-1.69(\mathrm{CN})$ \\
\hline U1354C-S6 & U1354C-9X-2, 20 & 117.80 & Muddy shelly sand & Sharp contact; burrowed & U13 & 121 & $\begin{array}{l}\text { 1.69-1.81 (CN); Plio/Pleist. boundary picked between } 122.20 \\
\text { and } 133.37 \mathrm{~m} \text {; above this between } 1.73 \text { and } 1.81(\mathrm{CN}) \text {; } \\
\text { below this }>2.78(\mathrm{CN})\end{array}$ \\
\hline *U1354C-S7 & U1354C-10X-5, 75 & 132.35 & Muddy shelly sand & Sharp contact; burrowed & U12 & 156 & $>2.78(\mathrm{CN})$, possibly older than 3.7 \\
\hline U1354C-S7 & U1354C-12X-1, 110 & 145.80 & Muddy shelly sand & Sharp contact; burrowed & U12 & 156 & \\
\hline *U1354C-S7 & U1354C-13X-CC, 5 & 162.76 & Muddy shelly sand & Sharp contact; burrowed & U12 & 156 & \\
\hline U1354C-S7.1 & U1354C-15X-CC, 29 & 181.01 & Shelly sandy mud & Concretions; contact not recovered & U11 & 177 & $>2.78(\mathrm{CN})$, possibly older than 3.7 \\
\hline U1354C-s8 & U1354C-19X-CC, 22 & 217.80 & Shelly sandy marl & Possible contact at base of $\mathrm{CC}$ & U10 & 211 & $3.7(\mathrm{CN})-4.3(\mathrm{PF})$ \\
\hline *U1354C-S8 & U1354C-20X-CC, 42 & 221.82 & Shelly sandy marl & Concretions; contact not recovered & U10 & 211 & \\
\hline *U1354C-S8 & U1354C-22X-3, 40 & 243.90 & Shelly sandy marl & Sharp contact; burrowed & U10 & 211 & \\
\hline
\end{tabular}

Notes: ${ }^{*}=$ alternative contact facies for lithologic surface. $\mathrm{CN}=$ calcareous nannofossil, $\mathrm{PF}=$ planktonic foraminifer. $\mathrm{B} / \mathrm{M}=\mathrm{Brunhes} / \mathrm{Matuyama}$. 
Table T4. Microfossil bioevents, Site U1354. (See table notes.)

\begin{tabular}{|c|c|c|c|c|c|c|c|c|}
\hline \multicolumn{2}{|c|}{ Core, section, interval $(\mathrm{cm})$} & \multirow[b]{2}{*}{ Microfossil } & \multirow{2}{*}{$\begin{array}{l}\text { Bioevents, unconformities, and epoch } \\
\text { boundaries }\end{array}$} & \multirow[b]{2}{*}{ Age $(\mathrm{Ma})$} & \multicolumn{4}{|c|}{ Depth CSF-A (m) } \\
\hline Top & Bottom & & & & Top & Bottom & Midpoint & \pm \\
\hline 317-U1354A- & 317-U1354A- & & & & & & & \\
\hline $6 \mathrm{H}-4,0-1$ & $6 \mathrm{H}-\mathrm{CC}$ & $\mathrm{CN}$ & LO Emiliania huxleyi & $0.29( \pm 0.03)$ & 20.80 & 24.25 & 22.53 & 1.73 \\
\hline $9 \mathrm{H}-\mathrm{CC}$ & $10 \mathrm{H}-\mathrm{CC}$ & $\mathrm{BF}$ & HO Siphotextularia wairoana & $0.34( \pm 0.1)$ & 46.88 & 53.76 & 50.32 & 3.44 \\
\hline $9 \mathrm{H}-\mathrm{CC}$ & $10 \mathrm{H}-\mathrm{CC}$ & $\mathrm{BF}$ & Proxifrons advenum & $>0.40( \pm 0.2)$ & 46.88 & 53.76 & 50.32 & 3.44 \\
\hline $12 \mathrm{H}-1,6$ & $12 \mathrm{H}-6,31$ & $\mathrm{CN}$ & HO Pseudoemiliania lacunosa & $0.44( \pm 0.01)$ & 56.36 & 64.11 & 60.24 & 3.88 \\
\hline $12 \mathrm{H}-\mathrm{CC}$ & $13 \mathrm{H}-\mathrm{CC}$ & $\mathrm{BF}$ & HO Bolivinita pliozea & $0.60( \pm 0.2)$ & 64.90 & 73.44 & 69.17 & 4.27 \\
\hline $15 \mathrm{H}-\mathrm{CC}$ & $17 \mathrm{H}-\mathrm{CC}$ & & Unconformity, $\sim 0.3$ m.y. missing & & 76.20 & 80.16 & 78.18 & 1.98 \\
\hline $15 \mathrm{H}-\mathrm{CC}$ & $17 \mathrm{H}-\mathrm{CC}$ & $\mathrm{CN}$ & HO Gephyrocapsa $>5.5 \mu \mathrm{m}$ & $1.26( \pm 0.01)$ & 76.20 & 80.16 & 78.18 & 1.98 \\
\hline $18 \mathrm{H}-\mathrm{CC}$ & $19 \mathrm{H}-\mathrm{CC}$ & $\mathrm{CN}$ & HO Helicosphaera sellii & $1.34( \pm 0.01)$ & 80.33 & 85.38 & 82.86 & 2.53 \\
\hline 317-U1354B- & 317-U1354B- & & & & & & & \\
\hline $7 \mathrm{H}-\mathrm{CC}$ & $8 \mathrm{H}-\mathrm{CC}$ & $\mathrm{CN}$ & LO Emiliania huxleyi & $0.29( \pm 0.03)$ & 26.50 & 33.45 & 29.98 & 3.48 \\
\hline $9 \mathrm{H}-\mathrm{CC}$ & $10 \mathrm{H}-\mathrm{CC}$ & $\mathrm{BF}$ & HO Siphotextularia wairoana & $0.34( \pm 0.1)$ & 41.46 & 50.29 & 45.88 & 4.42 \\
\hline $10 \mathrm{H}-\mathrm{CC}$ & $11 \mathrm{H}-\mathrm{CC}$ & $\mathrm{BF}$ & HO Bolivinita pliozea & $0.60( \pm 0.2)$ & 50.29 & 57.73 & 54.01 & 3.72 \\
\hline $11 \mathrm{H}-\mathrm{CC}$ & $12 \mathrm{H}-\mathrm{CC}$ & $\mathrm{CN}$ & HO Pseudoemiliania lacunosa & $0.44( \pm 0.01)$ & 57.73 & 62.44 & 60.09 & 2.36 \\
\hline $15 \mathrm{H}-1,15$ & $15 \mathrm{H}-1,39$ & & Unconformity, $\sim 0.3$ m.y. missing & & 73.65 & 73.89 & 73.77 & 0.12 \\
\hline $15 \mathrm{H}-1,15$ & $15 \mathrm{H}-1,39$ & $\mathrm{CN}$ & HO Gephyrocapsa $a>5.5 \mu \mathrm{m}$ & $1.26( \pm 0.01)$ & 73.65 & 73.89 & 73.77 & 0.12 \\
\hline 317-U1354C- & 317-U1354C- & & & & & & & \\
\hline $2 \mathrm{H}-\mathrm{CC}$ & $2 \mathrm{H}-\mathrm{CC}$ & $\mathrm{BF}$ & Bolivinita pliozea & $>0.60( \pm 0.2)$ & 72.57 & 72.57 & 72.57 & 0.00 \\
\hline $2 \mathrm{H}-\mathrm{CC}$ & $4 \mathrm{H}-\mathrm{CC}$ & & Unconformity, $\sim 0.3$ m.y. missing & & 72.57 & 84.37 & 78.47 & 5.90 \\
\hline $2 \mathrm{H}-\mathrm{CC}$ & $4 \mathrm{H}-\mathrm{CC}$ & $\mathrm{CN}$ & HO Gephyrocapsa $>5.5 \mu \mathrm{m}$ & $1.26( \pm 0.01)$ & 72.57 & 84.37 & 78.47 & 5.90 \\
\hline $4 \mathrm{X}-\mathrm{CC}$ & $5 \mathrm{X}-\mathrm{CC}$ & $\mathrm{CN}$ & HO Helicosphaera sellii & $1.34( \pm 0.01)$ & 84.37 & 86.84 & 85.61 & 1.24 \\
\hline $6 \mathrm{X}-\mathrm{CC}$ & $7 \mathrm{X}-\mathrm{CC}$ & $\mathrm{CN}$ & LO Gephyrocaps $a>4 \mu \mathrm{m}$ & $1.69( \pm 0.05)$ & 97.76 & 105.86 & 101.81 & 4.05 \\
\hline $8 \mathrm{X}-\mathrm{CC}$ & 9X-CC & $\mathrm{CN}$ & LO Gephyrocapsa caribbeanica & $1.73( \pm 0.01)$ & 111.56 & 122.20 & 116.88 & 5.32 \\
\hline 9X-CC & $10 \mathrm{X}-\mathrm{CC}$ & & Pliocene/Pleistocene boundary & 1.81 & 122.20 & 133.37 & 127.79 & 5.59 \\
\hline 9X-CC & $10 \mathrm{X}-\mathrm{CC}$ & & Unconformity & & 122.20 & 133.37 & 127.79 & 5.59 \\
\hline $11 \mathrm{X}-\mathrm{CC}$ & $12 \mathrm{X}-\mathrm{CC}$ & $\mathrm{CN}$ & HO Reticulofenestra ampla & $2.78( \pm 0.1)$ & 144.95 & 152.98 & 148.97 & 4.02 \\
\hline $16 \mathrm{X}-\mathrm{CC}$ & $17 X-C C$ & $\mathrm{CN}$ & HO Reticulofenestra pseudoumbilicus & $3.70( \pm 0.01)$ & 183.20 & 192.75 & 187.98 & 4.78 \\
\hline $27 X-C C$ & $28 \mathrm{X}-\mathrm{CC}$ & PF & HO Zeaglobigerina woodi & $2.7( \pm 0.1)$ & 293.32 & 299.64 & 296.48 & 3.16 \\
\hline $36 \mathrm{X}-\mathrm{CC}$ & $36 \mathrm{X}-\mathrm{CC}$ & $\mathrm{PF}$ & Globoconella inflata s.s. & $<4.30( \pm 0.3)$ & 375.33 & 375.33 & 375.33 & \\
\hline
\end{tabular}

Notes: $\mathrm{CN}=$ calcareous nannofossil, $\mathrm{BF}=$ benthic foraminifer, $\mathrm{PF}=$ planktonic foraminifer. $\mathrm{LO}=$ lowest occurrence, $\mathrm{HO}=$ highest occurrence. This table is also available in ASCII.

Table T5. Calcareous nannofossil abundance, Site U1354. This table is available in an oversized format. 


\begin{tabular}{|c|c|c|c|c|c|c|c|c|c|}
\hline $\begin{array}{l}\text { Core, section, } \\
\text { interval }(\mathrm{cm})\end{array}$ & $\begin{array}{l}\text { Top depth } \\
\text { CSF-A }(m)\end{array}$ & $\begin{array}{l}\text { Interpreted } \\
\text { age }\end{array}$ & $\begin{array}{c}\text { Nannofossil } \\
\text { zone }\end{array}$ & $\begin{array}{l}\text { NZ stage } \\
\text { correlation }\end{array}$ & NZ stage & $\begin{array}{l}\text { Age } \\
(\mathrm{Ma})\end{array}$ & $\begin{array}{c}\begin{array}{c}\text { Planktonic } \\
\text { foraminifers } \\
(\%)\end{array} \\
\end{array}$ & Oceanicity & Key species and comments \\
\hline $\begin{array}{c}\text { 317-U1354A- } \\
1 \mathrm{H}-1,0\end{array}$ & 0.00 & Holocene & \multirow{8}{*}{ NN21 } & \multirow{11}{*}{$\begin{array}{l}\text { Haweran to } \\
\text { upper } \\
\text { Castlecliffian } \\
(\mathrm{Wq}-\mathrm{uWc})\end{array}$} & Wq-uWo & $0-4.3$ & 53 & Extraneritic & \multirow{17}{*}{$\begin{array}{l}\text { Globoconella inflata; mudline sample, Holocene inferred, not identified biostratigraphically } \\
\text { Globoconella inflata; [base NN21B, <0.08 Ma] } \\
\text { [Haweran benthic Loxostomum karrerianum; top NN21A, }>0.08 \mathrm{Ma} \text { ] } \\
\text { ND, no planktonics } \\
\text { ND } \\
\text { [Nannofossil, LO Emiliania huxleyi, base NN21, } 0.29 \mathrm{Ma}] \\
\text { Globoconella cf. puncticuloides (HO at Site U1352= } 0.5 \mathrm{Ma} \text { ), Truncorotalia truncatulinoides } \\
\text { (1S:0D), Globoconella inflata } \\
\text { Globoconella inflata } \\
\text { Truncorotalia truncatulinoides (4S:0D), Globoconella inflata } \\
\text { Globoconella inflata, Globigerinella aequilateralis; [nannofossil, HO Pseudoemiliania lacunosa, } \\
\text { 0.44 Ma] } \\
\text { Globoconella inflata } \\
\text { ND } \\
\text { Globoconella inflata } \\
\text { ND } \\
\text { ND; [nannofossils }>1.26 \text { Ma; unconformity, } ~ 0.3 \mathrm{~m} . y . \text { missing between Samples } 15 \mathrm{H}-\mathrm{CC} \\
\text { and 17H-CC] } \\
\text { Globoconella inflata; [benthic Siphotextularia wairoana] } \\
\text { ND; [benthic Siphotextularia wairoana; nannofossil, HO Helicosphaera sellii, } 1.34 \mathrm{Ma} \text { ] }\end{array}$} \\
\hline $1 \mathrm{H}-\mathrm{CC}$ & 3.78 & \multirow{16}{*}{ Pleistocene } & & & Wq-uWo & $0-4.3$ & 1 & & \\
\hline $2 \mathrm{H}-\mathrm{CC}$ & 12.26 & & & & Wq & $0-0.34$ & 3 & Inner neritic & \\
\hline $3 \mathrm{H}-\mathrm{CC}$ & 13.99 & & & & & & 0 & Inner neritic & \\
\hline $4 \mathrm{H}-\mathrm{CC}$ & 14.30 & & & & Wq-uWo & $0-4.3$ & 2 & & \\
\hline $5 \mathrm{H}-\mathrm{CC}$ & 14.69 & & & & Wq-uWo & $0-4.3$ & 43 & Extraneritic & \\
\hline $6 \mathrm{H}-\mathrm{CC}$ & 24.25 & & & & \multirow{3}{*}{$\begin{array}{c}\text { Wq-uWo } \\
\text { uWc }\end{array}$} & \multirow{3}{*}{$\begin{array}{r}0-4.3 \\
\sim 0.5-1.1\end{array}$} & \multirow{3}{*}{$\begin{array}{r}1 \\
1 \\
51\end{array}$} & & \\
\hline $7 \mathrm{H}-\mathrm{CC}$ & 31.33 & & & & & & & Inner neritic & \\
\hline $8 \mathrm{H}-\mathrm{CC}$ & 38.14 & & \multirow{3}{*}{ NN20 } & & & & & Extraneritic & \\
\hline $9 \mathrm{H}-\mathrm{CC}$ & $\begin{array}{l}53.76 \\
4688\end{array}$ & & & & Wq-uWo & $0-4.3$ & 15 & Outer shelf & \\
\hline $11 \mathrm{H}-\mathrm{CC}$ & $\begin{array}{l}46.80 \\
60.14\end{array}$ & & & & $\begin{array}{l}\text { Wq-uWo } \\
\text { Wq-uWo }\end{array}$ & $\begin{array}{l}0-1.1 \\
0-4.3\end{array}$ & $\begin{array}{l}22 \\
12\end{array}$ & \multirow{7}{*}{ Inner neritic } & \\
\hline $\begin{array}{l}12 \mathrm{H}-\mathrm{CC} \\
13 \mathrm{H}-\mathrm{CC}\end{array}$ & $\begin{array}{l}64.90 \\
73.44\end{array}$ & & \multirow{6}{*}{ NN19 } & \multirow{6}{*}{$\begin{array}{l}\text { Castlecliffian } \\
\text { (Wc) }\end{array}$} & Wq-uWo & $0-4.3$ & $\begin{array}{l}5 \\
2\end{array}$ & & \\
\hline $14 \mathrm{H}-\mathrm{CC}$ & 75.41 & & & & Wq-uWo & $0-4.3$ & 2 & & \\
\hline $15 \mathrm{H}-\mathrm{CC}$ & 76.20 & & & & & & 1 & & \\
\hline $17 \mathrm{H}-\mathrm{CC}$ & 80.16 & & & & & & 1 & & \\
\hline $18 \mathrm{H}-\mathrm{CC}$ & 80.33 & & & & Wc-uWo & $0.34-4.3$ & 6 & & \\
\hline $19 \mathrm{H}-\mathrm{CC}$ & 85.38 & & & & Wc-uWo & $>0.34$ & 1 & & \\
\hline
\end{tabular}

Notes: $\mathrm{ND}=$ not determined. $\mathrm{HO}=$ highest occurrence. $\mathrm{S}=$ sinistral, $\mathrm{D}=$ dextral. For New Zealand (NZ) stage abbreviations, see Figure F5 in the "Methods" chapter. This table is also available in ASCII. 


\begin{tabular}{|c|c|c|c|c|c|c|c|c|c|}
\hline $\begin{array}{l}\text { Core, section, } \\
\text { interval }(\mathrm{cm})\end{array}$ & $\begin{array}{l}\text { Top depth } \\
\text { CSF-A (m) }\end{array}$ & $\begin{array}{l}\text { Interpreted } \\
\text { age }\end{array}$ & $\begin{array}{c}\text { Nannofossil } \\
\text { zone }\end{array}$ & $\begin{array}{l}\text { NZ stage } \\
\text { correlation }\end{array}$ & NZ stage & $\begin{array}{l}\text { Age } \\
(\mathrm{Ma})\end{array}$ & $\begin{array}{c}\text { Planktonic } \\
\text { foraminifers } \\
(\%)\end{array}$ & Oceanicity & Key species and comments \\
\hline $\begin{array}{l}\text { 317-U1354B- } \\
1 \mathrm{H}-1,0\end{array}$ & 0.00 & Holocene & \multirow{8}{*}{ NN21 } & \multirow{10}{*}{$\begin{array}{l}\text { Haweran } \\
(W q)\end{array}$} & \multirow[t]{5}{*}{ Wq-uWo } & \multirow[t]{5}{*}{$0-4.3$} & \multirow{4}{*}{$\begin{array}{l}2 \\
1 \\
1\end{array}$} & Extraneritic & \multirow{16}{*}{$\begin{array}{l}\text { Globoconella inflata; [nannofossil, LO Emiliania huxleyi, base NN21, } 0.29 \mathrm{Ma} \text { ] } \\
\text { Globoconella inflata } \\
\text { Globoconella inflata } \\
\text { Globoconella inflata; [benthic HO Siphotextularia wairoana] } \\
\text { Globoconella inflata; [benthic HO Bolivinita pliozea] } \\
\text { Globoconella inflata, Globigerinoides ruber; [benthics Siphotextularia wairoana; Bolivinita } \\
\text { pliozea; HO Pseudoemiliania lacunosa, } 0.44 \mathrm{Ma} \text { ] } \\
\text { [Benthic Siphotextularia wairoana, Bolivinita pliozea] } \\
\text { Globoconella inflata; [nannofossil, HO Gephyrocapsa }>5.5 \mu \mathrm{m} \text {, unconformity, } \sim 0.3 \mathrm{~m} . y \\
\text { missing at Section } 15 \mathrm{H}-1,15-39 \mathrm{~cm} \text { ] } \\
\text { Globoconella inflata }\end{array}$} \\
\hline $1 \mathrm{H}-\mathrm{CC}$ & 4.06 & \multirow{15}{*}{ Pleistocene } & & & & & & & \\
\hline $2 \mathrm{H}-\mathrm{CC}$ & 11.68 & & & & & & & & \\
\hline $3 \mathrm{H}-\mathrm{CC}$ & 12.08 & & & & & & & & \\
\hline $4 \mathrm{H}-\mathrm{CC}$ & 17.64 & & & & & & 5 & Inner neritic & \\
\hline $5 \mathrm{H}-\mathrm{CC}$ & 20.31 & & & & Wq-uWo & $0-4.3$ & 5 & & \\
\hline $6 \mathrm{H}-\mathrm{CC}$ & 20.88 & & & & & & 0 & & \\
\hline $7 \mathrm{H}-\mathrm{CC}$ & 26.50 & & & & Wq-uWo & $0-4.3$ & 10 & & \\
\hline $8 \mathrm{H}-\mathrm{CC}$ & 33.45 & & \multirow{4}{*}{ NN20 } & & Wq-uWo & $0-4.3$ & 40 & Extraneritic & \\
\hline 9H-CC & 41.46 & & & & Wq-uWo & $0-4.3$ & 13 & Inner neritic & \\
\hline $10 \mathrm{H}-\mathrm{CC}$ & 50.29 & & & \multirow{6}{*}{$\begin{array}{l}\text { Castlecliffian } \\
\text { (Wc) }\end{array}$} & Wc-uWo & $0.34-4.3$ & 16 & Outer neritic & \\
\hline $11 \mathrm{H}-\mathrm{CC}$ & 57.73 & & & & Wc-uWo & $0.6-4.3$ & 18 & Outer nerric & \\
\hline $12 \mathrm{H}-\mathrm{CC}$ & 62.44 & & \multirow{4}{*}{ NN19 } & & Wc-uWo & $0.6-4.3$ & 12 & \multirow{4}{*}{ Inner neritic } & \\
\hline $13 \mathrm{H}-\mathrm{CC}$ & 70.40 & & & & Wc & $>0.6$ & 1 & & \\
\hline $14 \mathrm{H}-\mathrm{CC}$ & 73.56 & & & & Wq-uWo & $0-4.3$ & 1 & & \\
\hline $15 \mathrm{H}-\mathrm{CC}$ & 77.25 & & & & Wc-uWo & $0-4.3$ & 1 & & \\
\hline
\end{tabular}

Notes: $\mathrm{LO}=$ lowest occurrence, $\mathrm{HO}=$ highest occurrence. For New Zealand (NZ) stage abbreviations, see Figure F5 in the "Methods" chapter. This table is also available in ASCII. 
Table T8. Planktonic foraminiferal summary, Hole U1354C. (See table notes.)

\begin{tabular}{|c|c|c|c|c|c|c|c|c|c|}
\hline Core, section & $\begin{array}{l}\text { Top depth } \\
\text { CSF-A (m) }\end{array}$ & $\begin{array}{l}\text { Interpreted } \\
\quad \text { age }\end{array}$ & $\begin{array}{c}\text { Nannofossil } \\
\text { zone }\end{array}$ & $\begin{array}{l}\text { NZ stage } \\
\text { correlation }\end{array}$ & NZ stage & $\begin{array}{l}\text { Age } \\
(\mathrm{Ma})\end{array}$ & $\begin{array}{c}\text { Planktonic } \\
\text { foraminifers } \\
(\%)\end{array}$ & Oceanicity & Key species and comments \\
\hline 317-U1354C- & & \multirow{10}{*}{ Pleistocene } & \multirow{10}{*}{ NN19 } & \multirow{6}{*}{$\begin{array}{l}\text { Castlecliffian } \\
\quad(W c)\end{array}$} & & & & \multirow{10}{*}{ Inner neritic } & \\
\hline $2 \mathrm{H}-\mathrm{CC}$ & 72.57 & & & & Wq-uWo & $0-4.3$ & 3 & & Globoconella inflata \\
\hline $3 \mathrm{H}-\mathrm{CC}$ & 78.13 & & & & Wq-uWo & $0-4.3$ & 1 & & Globoconella inflata \\
\hline $4 \mathrm{X}-\mathrm{CC}$ & 84.37 & & & & Wq-uWo & $0-4.3$ & 1 & & Globoconella inflata; [nannofossil, HO Gephyrocapsa $>5.5 \mu \mathrm{m}, 1.26 \mathrm{Ma}$ ] \\
\hline $5 \mathrm{X}-\mathrm{CC}$ & 86.84 & & & & \multirow{3}{*}{ Wq-uWo } & \multirow{3}{*}{$0-4.3$} & 5 & & ND; [nannofossil, HO Helicosphaera sellii, 1.34 Ma] \\
\hline $6 \mathrm{X}-\mathrm{CC}$ & 97.76 & & & & & & 1 & & Globoconella inflata; [nannofossil, LO Gephyrocapsa $>4 \mu \mathrm{m}, 1.69 \mathrm{Ma}$ ] \\
\hline 7X-CC & 105.86 & & & \multirow{4}{*}{$\begin{array}{l}\text { Nukumaruan } \\
(\mathrm{Wn})\end{array}$} & & & 8 & & \multirow{5}{*}{$\begin{array}{l}\text { ND } \\
\text { ND; [nannofossil, LO Gephyrocapsa caribbeanica, } 1.73 \mathrm{Ma} \text { ] } \\
\text { Globoconella inflata } \\
\text { No planktonics } \\
\text { Globoconella inflata; [nannofossils, Pliocene/Pleistocene boundary between Samples } \\
8 \mathrm{H}-\mathrm{CC} \text { and } 11 \mathrm{H}-\mathrm{CC} \text { ] }\end{array}$} \\
\hline $8 \mathrm{X}-\mathrm{CC}$ & 111.56 & & & & \multirow{4}{*}{$\begin{array}{l}\text { Wq-uWo } \\
\text { Wq-uWo }\end{array}$} & \multirow{2}{*}{$0-4.3$} & 4 & & \\
\hline 9X-CC & 122.20 & & & & & & $<1$ & & \\
\hline $10 \mathrm{X}-\mathrm{CC}$ & 133.37 & & & & & & 0 & & \\
\hline $11 \mathrm{X}-\mathrm{CC}$ & 144.95 & \multirow{6}{*}{ middle Pliocene } & \multirow{5}{*}{ NN16 } & \multirow{6}{*}{$\begin{array}{c}\text { Mangapanian to } \\
\text { Waipipian } \\
\text { (Wm-Wp) }\end{array}$} & & $0-4.3$ & 20 & Outer neritic & \\
\hline $12 X-C C$ & 152.98 & & & & \multirow[t]{9}{*}{ Wc } & \multirow[t]{5}{*}{$>0.6$} & 1 & & \multirow{9}{*}{$\begin{array}{l}\text { [Benthic, Bolivinita pliozea; nannofossil, HO Pseudoemiliania lacunosa }>2.78 \mathrm{Ma} \text { ] } \\
\text { ND, no planktonics } \\
\text { ND } \\
\text { ND, no planktonics } \\
\text { ND; [top NN15 HO Reticulofenestra pseudoumbilicus, } 3.70 \mathrm{Ma} \text { ] } \\
\text { ND } \\
\text { ND, no planktonics } \\
\text { ND, no planktonics } \\
\text { ND }\end{array}$} \\
\hline $13 \mathrm{X}-\mathrm{CC}$ & 163.04 & & & & & & 0 & & \\
\hline $14 \mathrm{X}-\mathrm{CC}$ & 166.16 & & & & & & $<1$ & & \\
\hline $15 \mathrm{X}-\mathrm{CC}$ & 181.01 & & & & & & 0 & & \\
\hline $16 \mathrm{X}-\mathrm{CC}$ & 183.20 & & \multirow{18}{*}{$\begin{array}{l}\text { NN15- } \\
\text { NN14 }\end{array}$} & & & & 1 & Inner neritic & \\
\hline $17 X-C C$ & 192.75 & \multirow{17}{*}{ early Pliocene } & & \multirow{17}{*}{$\begin{array}{l}\text { upper Opoitian } \\
\quad \text { (uWo) }\end{array}$} & & & 3 & & \\
\hline $18 \mathrm{X}-\mathrm{CC}$ & 207.65 & & & & & & 0 & & \\
\hline 19X-CC & 217.90 & & & & & & 0 & & \\
\hline $20 \mathrm{X}-\mathrm{CC}$ & 221.82 & & & & & & 0 & & \\
\hline $21 X-C C$ & 240.77 & & & & \multirow[t]{6}{*}{ IWc-uWo } & \multirow[t]{5}{*}{$0.5-4.3$} & 21 & Outer neritic & \multirow{2}{*}{$\begin{array}{l}\text { Truncorotalia crassaformis (0S:1D), Globoconella puncticuloides, Globoconella inflata } \\
\text { ND }\end{array}$} \\
\hline $22 \mathrm{X}-\mathrm{CC}$ & 247.41 & & & & & & $<1$ & & \\
\hline $23 \mathrm{X}-\mathrm{CC}$ & 250.81 & & & & & & 0 & & ND, no planktonics \\
\hline $25 \mathrm{X}-\mathrm{CC}$ & 269.49 & & & & & & $<1$ & & ND \\
\hline $26 \mathrm{X}-\mathrm{CC}$ & 280.73 & & & & & & $<1$ & & ND, Orbulina universa \\
\hline $27 X-C C$ & 293.32 & & & & & & 0 & & ND, no planktonics \\
\hline $28 \mathrm{X}-\mathrm{CC}$ & 299.64 & & & & $\mathrm{IWm}$ & $>2.7 ?$ & $<1$ & & Zeaglobigerina woodi? \\
\hline $29 X-C C$ & 308.34 & & & & IWm-uWo & $2.7-4.3$ & 1 & Inner neritic & Globoconella inflata, Zeaglobigerina woodi \\
\hline $30 \mathrm{X}-\mathrm{CC}$ & 318.65 & & & & & & $<1$ & & ND, Orbulina universa \\
\hline $31 \mathrm{X}-\mathrm{CC}$ & 326.78 & & & & IWm-uWo & $2.7-4.3$ & 2 & & $\begin{array}{l}\text { Globoconella inflata, Globoconella puncticuloides, Zeaglobigerina woodi, } \\
\text { Neogloboquadrina pachyderma, Neogloboquadrina incompta }\end{array}$ \\
\hline $32 \mathrm{X}-\mathrm{CC}$ & 336.92 & & & & & & $<1$ & & Neogloboquadrina pachyderma? \\
\hline $33 \mathrm{X}-\mathrm{CC}$ & 345.80 & & & & & $<4.3$ & 5 & & Globoconella puncticuloides, Neogloboquadrina incompta, Orbulina universa \\
\hline $36 \mathrm{X}-\mathrm{CC}$ & 375.33 & & & & & $2.7-4.3$ & 1 & & Globoconella puncticuloides, Zeaglobigerina woodi (common); warm, temperate \\
\hline
\end{tabular}

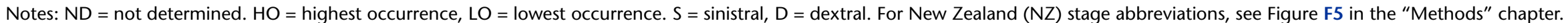
This table is also available in ASCII. 
Table T9. Planktonic foraminiferal abundance, preservation, and distribution, Hole U1354A. (See table notes.)

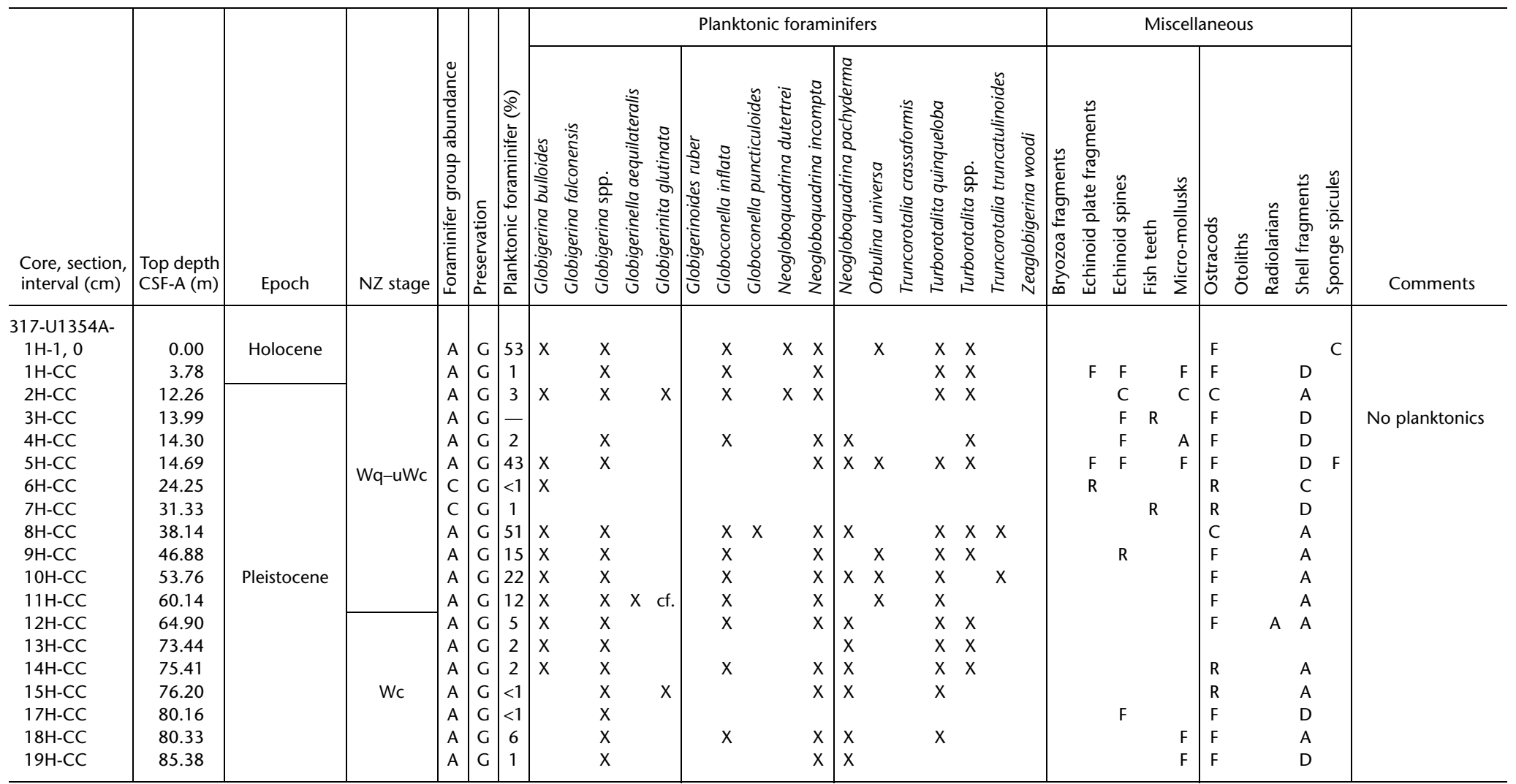

Notes: Abundance: $\mathrm{D}=$ dominant, $\mathrm{A}=$ abundant, $\mathrm{C}=$ common, $\mathrm{F}=$ few $\mathrm{R}=$ rare, $\mathrm{X}=$ present, ? = questionable presence. Preservation: $\mathrm{G}=$ good, $\mathrm{M}=$ moderate, $\mathrm{P}=$ poor. $-=$ no data. For New Zealand (NZ) stage abbreviations, see Figure F5 in the "Methods" chapter. This table is also available in ASCII. 


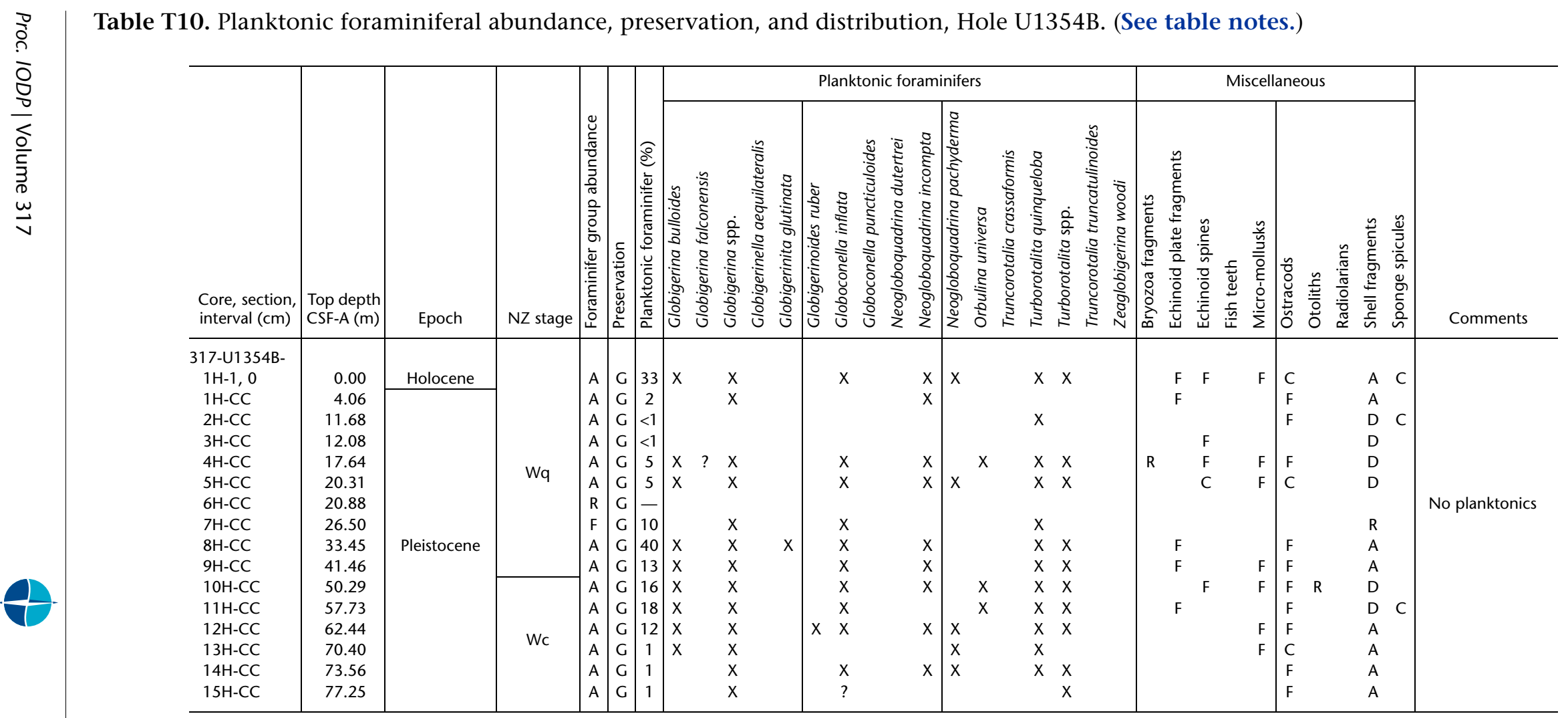

Notes: Abundance: $\mathrm{D}=$ dominant, $\mathrm{A}=$ abundant, $\mathrm{C}=$ common, $\mathrm{F}=$ few, $\mathrm{R}=$ rare, $\mathrm{X}=$ present, ? = questionable presence. Preservation: $\mathrm{G}=$ good, $\mathrm{M}=$ moderate, $\mathrm{P}=$ poor. $-=$ no data. For New Zealand (NZ) stage abbreviations, see Figure F5 in the "Methods" chapter. This table is also available in ASCII. 


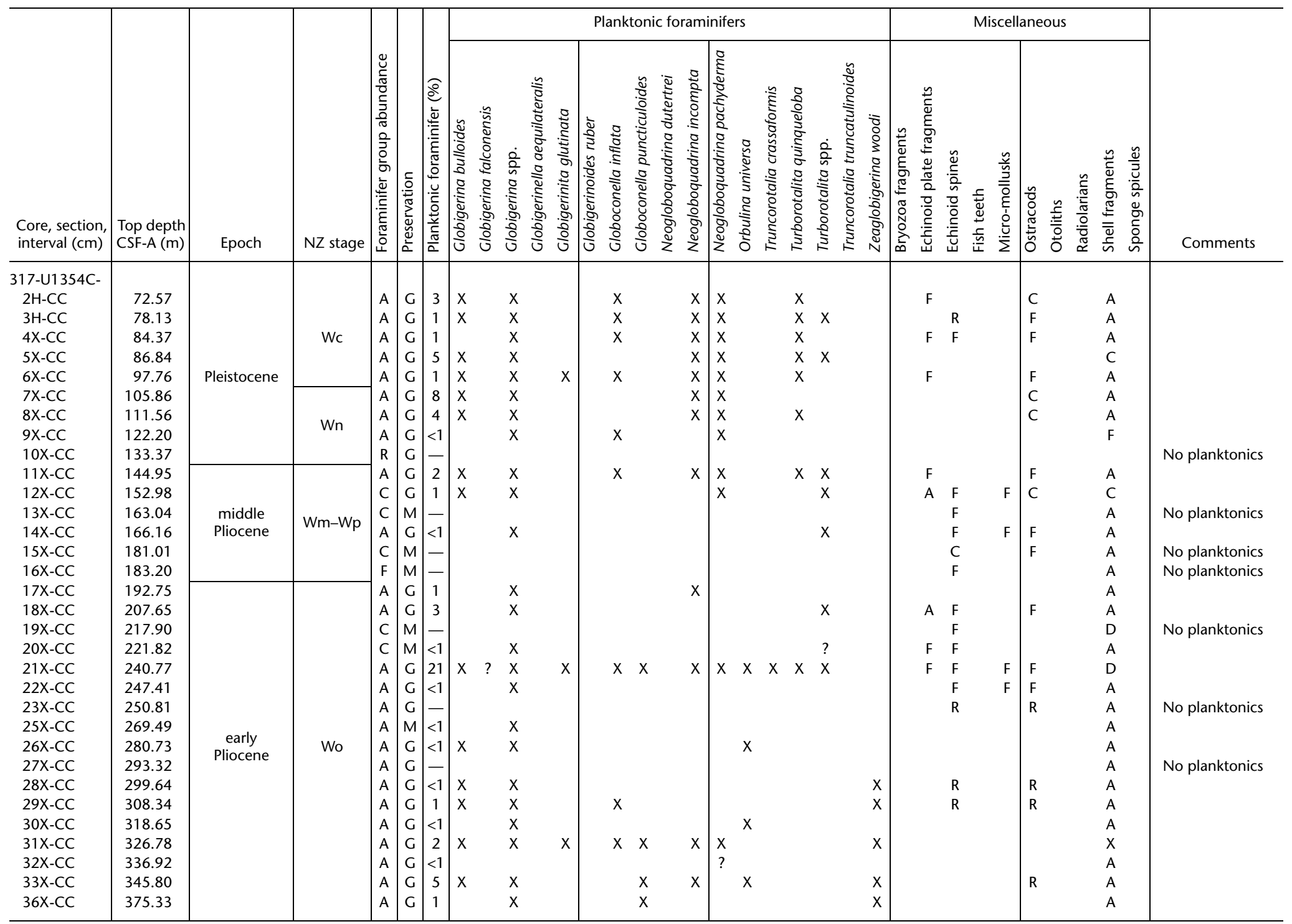

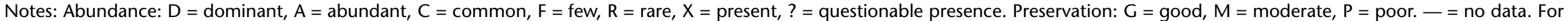
New Zealand (NZ) stage abbreviations, see Figure F5 in the "Methods" chapter. This table is also available in ASCII. 
Table T12. Benthic foraminifer abundance, preservation, and distribution, Site U1354. This table is available in an oversized format.

Table T13. Diatom abundance, preservation, and distribution, Site U1354. (See table notes.)
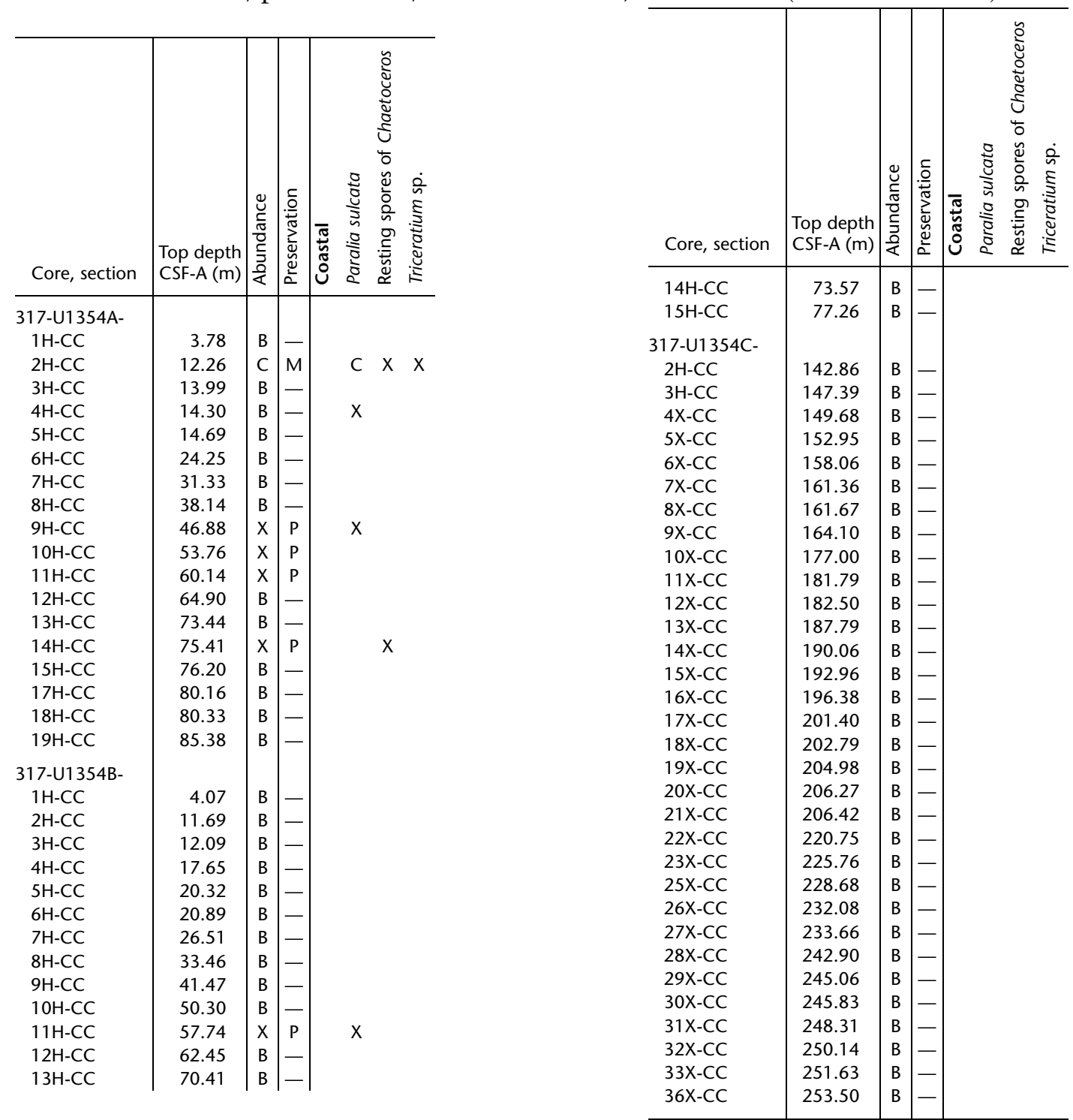

Notes: Abundance: $\mathrm{C}=$ common, $\mathrm{B}=$ barren, $\mathrm{X}=$ present. Preservation: $\mathrm{M}=$ moderate, $\mathrm{P}=$ poor, $-=$ no data. This table is also available in ASCII. 
Table T14. Invertebrate macrofossils, Site U1354. (See table notes.)

\begin{tabular}{|c|c|c|c|c|c|c|c|}
\hline \multirow[b]{2}{*}{ Taxon } & \multirow{2}{*}{$\begin{array}{l}\text { Hole, core, section, } \\
\text { interval }(\mathrm{cm})\end{array}$} & \multirow{2}{*}{$\begin{array}{l}\text { Sediment } \\
\text { type }\end{array}$} & \multirow[b]{2}{*}{ Habitat } & \multicolumn{3}{|c|}{ Age (Ma) } & \multirow[b]{2}{*}{ International timescale } \\
\hline & & & & not $>$ than & not $<$ than & NZ stage & \\
\hline & $317-$ & & & & & & \\
\hline Barytellina crassidens tertia (Fleming) & U1354B-13H-2, 68 & $S / Z$ & Estuarine, paralic & 3.0 & 0.0 & Wwp-R & late Pliocene to recent \\
\hline Dosinia sp. indet. & U1354B-13H-2, 68 & $\mathrm{~s}$ & Shoreface, usually $<20 \mathrm{~m}$ & & & & \\
\hline Eumarcia (Atamarcia) benhami (Marwick) & U1354B-13H-2, 68 & $\mathrm{~s}$ & Shoreface-inner shelf & 6.5 & 1.6 & Tk-Wn & late late Miocene to late late Pliocene \\
\hline
\end{tabular}

Notes: $\mathrm{S}=$ sand, $\mathrm{Z}=$ silt. For New Zealand (NZ) stage abbreviations, see Figure F5 in the "Methods" chapter. This table is also available in ASCII. 
Table T15. Headspace gas composition from sediments, Site U1354. (See table note.)

\begin{tabular}{|c|c|c|c|c|c|c|}
\hline $\begin{array}{l}\text { Core, section, } \\
\text { interval }(\mathrm{cm})\end{array}$ & $\begin{array}{l}\text { Depth } \\
\text { CSF-A (m) }\end{array}$ & $\begin{array}{c}\mathrm{C}_{1} \\
\text { (ppmv) }\end{array}$ & $\begin{array}{c}\mathrm{C}_{2} \\
\text { (ppmv) }\end{array}$ & $\begin{array}{c}\mathrm{CO}_{2} \\
\text { (ppmv) }\end{array}$ & $\begin{array}{c}\mathrm{C}_{1} \\
(\mathrm{mM})\end{array}$ & $C_{1} / C_{2}$ \\
\hline \multicolumn{7}{|l|}{ 317-U1354A- } \\
\hline $1 \mathrm{H}-2,0$ & 1.50 & 2.0 & 0.0 & ND & 0.00061 & ND \\
\hline $1 \mathrm{H}-3,0$ & 3.00 & 1.9 & 0.0 & ND & 0.00056 & ND \\
\hline $2 \mathrm{H}-2,0$ & 5.30 & 1.8 & 0.0 & ND & 0.00053 & ND \\
\hline $2 \mathrm{H}-4,0$ & 8.30 & 2.1 & 0.0 & ND & 0.00062 & ND \\
\hline $2 \mathrm{H}-6,0$ & 11.30 & 2.1 & 0.0 & ND & 0.00063 & ND \\
\hline $6 \mathrm{H}-2,0$ & 17.80 & 2.0 & 0.0 & ND & 0.00059 & ND \\
\hline $6 \mathrm{H}-4,0$ & 20.80 & 2.2 & 0.0 & ND & 0.00066 & ND \\
\hline $7 \mathrm{H}-4,0$ & 28.32 & 1.7 & 0.0 & ND & 0.00051 & ND \\
\hline $7 \mathrm{H}-6,0$ & 30.40 & 1.8 & 0.0 & ND & 0.00054 & ND \\
\hline $8 \mathrm{H}-2,0$ & 32.80 & 3.5 & 0.0 & ND & 0.00104 & ND \\
\hline $8 \mathrm{H}-4,0$ & 35.80 & 7.3 & 0.0 & ND & 0.00219 & ND \\
\hline $9 \mathrm{H}-2,0$ & 39.80 & 10.0 & 0.0 & ND & 0.00301 & ND \\
\hline $9 \mathrm{H}-4,0$ & 42.80 & 19.8 & 0.7 & ND & 0.00594 & 28 \\
\hline $9 \mathrm{H}-6,0$ & 45.80 & 23.4 & 1.3 & ND & 0.00703 & 18 \\
\hline $10 \mathrm{H}-2,0$ & 48.40 & 17.1 & 0.0 & ND & 0.00512 & ND \\
\hline $10 \mathrm{H}-4,0$ & 51.40 & 11.8 & 0.8 & ND & 0.00353 & 15 \\
\hline $11 \mathrm{H}-2,0$ & 55.30 & 3.6 & 0.0 & ND & 0.00109 & ND \\
\hline $12 \mathrm{H}-2,0$ & 57.80 & 3.3 & 0.0 & ND & 0.00099 & ND \\
\hline $12 \mathrm{H}-4,0$ & 60.80 & 4.0 & 0.0 & ND & 0.00120 & ND \\
\hline $12 \mathrm{H}-6,0$ & 63.80 & 3.2 & 0.0 & ND & 0.00096 & ND \\
\hline $13 \mathrm{H}-2,0$ & 66.40 & 2.6 & 0.0 & ND & 0.00079 & ND \\
\hline $13 \mathrm{H}-4,0$ & 69.40 & 2.3 & 0.0 & ND & 0.00069 & ND \\
\hline $13 \mathrm{H}-6,0$ & 72.46 & 2.5 & 0.0 & ND & 0.00074 & ND \\
\hline $14 \mathrm{H}-2,0$ & 75.10 & 3.2 & 0.0 & ND & 0.00096 & ND \\
\hline $17 \mathrm{H}-2,0$ & 79.30 & 2.0 & 0.0 & ND & 0.00059 & ND \\
\hline $19 \mathrm{H}-2,0$ & 81.90 & 2.4 & 0.0 & ND & 0.00072 & ND \\
\hline $19 \mathrm{H}-4,0$ & 84.40 & 2.4 & 0.0 & ND & 0.00072 & ND \\
\hline \multicolumn{7}{|l|}{ 317-U1354C- } \\
\hline $2 \mathrm{H}-2,0$ & 66.50 & 2.1 & 0.0 & ND & ND & ND \\
\hline $2 \mathrm{H}-4,0$ & 69.50 & 1.3 & 0.0 & ND & ND & ND \\
\hline $4 X-4,0$ & 82.60 & 1.0 & 0.0 & ND & ND & ND \\
\hline $5 X-3,109$ & 86.39 & 3.1 & 0.0 & ND & ND & ND \\
\hline $6 X-4,82$ & 97.22 & 1.8 & 0.0 & ND & ND & ND \\
\hline $7 X-3,0$ & 104.50 & 1.5 & 0.0 & ND & ND & ND \\
\hline $7 X-3,0$ & 104.50 & 1.5 & 0.0 & ND & ND & ND \\
\hline $8 X-4,0$ & 110.70 & 1.9 & 0.0 & ND & ND & ND \\
\hline $9 X-4,0$ & 120.60 & 2.0 & 0.0 & ND & ND & ND \\
\hline $10 X-5,0$ & 131.60 & 2.6 & 0.0 & ND & ND & ND \\
\hline $11 X-6,0$ & 142.60 & 3.6 & 0.0 & ND & ND & ND \\
\hline $12 X-6,0$ & 151.70 & 3.0 & 0.0 & ND & ND & ND \\
\hline $13 X-5,0$ & 160.30 & 3.5 & 0.0 & ND & ND & ND \\
\hline $14 X-2,0$ & 165.32 & 2.4 & 0.0 & ND & ND & ND \\
\hline $15 X-2,0$ & 175.00 & 1.9 & 0.0 & ND & ND & ND \\
\hline $15 X-4,0$ & 178.00 & 2.8 & 0.0 & ND & ND & ND \\
\hline $18 X-3,0$ & 205.30 & 21 & 4.4 & 458 & ND & 5 \\
\hline $19 X-3,0$ & 214.80 & 251 & 6.2 & 413 & ND & 40 \\
\hline $20 \mathrm{X}-1,37$ & 221.77 & 850 & 2.0 & 289 & ND & 418 \\
\hline $21 X-4,0$ & 235.50 & 13,687 & 22.2 & 224 & ND & 617 \\
\hline $22 X-4,0$ & 245.00 & 17,921 & 25.8 & 351 & ND & 695 \\
\hline $26 \mathrm{X}-1,143$ & 280.33 & 21,327 & 25.8 & 2,296 & ND & 826 \\
\hline $27 X-3,0$ & 291.45 & 21,008 & 24.4 & 1,985 & ND & 860 \\
\hline $28 \mathrm{X}-1,117$ & 299.27 & 13,963 & 17.4 & 2,595 & ND & 804 \\
\hline $29 X-1,27$ & 307.97 & 14,010 & 15.5 & 1,118 & ND & 903 \\
\hline $30 X-1,124$ & 318.24 & 11,870 & 16.6 & 509 & ND & 717 \\
\hline $32 X-1,144$ & 337.64 & 6,043 & 13.1 & 3,379 & ND & 462 \\
\hline $36 \mathrm{X}-1,34$ & 374.94 & 21,596 & 29.0 & 2,860 & ND & 745 \\
\hline
\end{tabular}

Note: ND = not determined. 
Table T16. Core void gas composition, Site U1354. (See table note.)

\begin{tabular}{lccc}
\hline $\begin{array}{c}\text { Hole, core, section, } \\
\text { interval }(\mathrm{cm})\end{array}$ & $\begin{array}{c}\text { Depth } \\
\text { CSF-A (m) }\end{array}$ & $\begin{array}{c}\mathrm{C}_{1} \\
\text { (ppmv) }\end{array}$ & $\begin{array}{c}\mathrm{C}_{2} \\
\text { (ppmv) }\end{array}$ \\
\hline 317- & & & \\
U1354A-14H-2,89 & 75.56 & 4.8 & 0 \\
U1354B-14H-2, 92 & 72.92 & 3.0 & 0 \\
\hline
\end{tabular}

Note: $C_{1}-C_{2}$ analyzed on GC3.

Table T17. Carbon and nitrogen analyses of sediments, Site U1354. (See table notes.)

\begin{tabular}{lrcccccc}
\hline $\begin{array}{c}\text { Core, section, } \\
\text { interval (cm) }\end{array}$ & $\begin{array}{c}\text { Depth } \\
\text { CSF-A }(\mathrm{m})\end{array}$ & $\begin{array}{c}\mathrm{IC} \\
(\mathrm{wt} \%)\end{array}$ & $\begin{array}{c}\mathrm{CaCO}_{3} \\
(\mathrm{wt} \%)\end{array}$ & $\begin{array}{c}\mathrm{TC} \\
(\mathrm{wt} \%)\end{array}$ & $\begin{array}{c}\mathrm{TN} \\
(\mathrm{wt} \%)\end{array}$ & $\begin{array}{c}\mathrm{TOC}_{\text {DIFF }} \\
(\mathrm{wt} \%)\end{array}$ & TOC $_{\text {DIFF }} / \mathrm{TN}$ \\
\hline $317-\mathrm{U} 1354 \mathrm{~B}-$ & & & & & & & \\
$1 \mathrm{H}-1,140$ & 1.40 & 1.59 & 13.26 & 2.50 & 0.072 & 0.91 & 12.6 \\
$2 \mathrm{H}-4,123$ & 9.83 & 2.04 & 17.01 & 2.53 & 0.019 & 0.49 & 25.9 \\
$4 \mathrm{H}-3,126$ & 16.36 & 2.74 & 22.83 & 3.38 & 0.041 & 0.64 & 15.5 \\
$5 \mathrm{H}-2,97$ & 20.17 & 4.19 & 34.94 & 4.47 & 0.023 & 0.28 & 11.9 \\
$7 \mathrm{H}-4,24$ & 24.56 & 0.15 & 1.29 & 0.20 & 0.004 & 0.05 & 11.8 \\
$8 \mathrm{H}-3,73$ & 30.33 & 0.59 & 4.89 & 1.22 & 0.038 & 0.63 & 16.8 \\
$9 \mathrm{H}-2,97$ & 35.97 & 1.52 & 12.69 & 1.88 & 0.024 & 0.36 & 15.1 \\
$10 \mathrm{H}-3,145$ & 45.95 & 1.81 & 15.09 & 2.22 & 0.039 & 0.41 & 10.6 \\
$10 \mathrm{H}-6,77$ & 49.77 & 3.09 & 25.76 & 4.21 & 0.082 & 1.12 & 13.7 \\
$11 \mathrm{H}-1,79$ & 51.29 & 0.16 & 1.30 & 0.32 & 0.031 & 0.16 & 5.4 \\
$12 \mathrm{H}-3,74$ & 60.66 & 1.16 & 9.65 & 1.45 & 0.029 & 0.29 & 10.1 \\
$13 \mathrm{H}-1,73$ & 63.23 & 3.19 & 26.56 & 3.87 & 0.054 & 0.68 & 12.6 \\
$14 \mathrm{H}-2,120$ & 73.20 & 5.01 & 41.77 & 5.69 & 0.024 & 0.68 & 28.7 \\
$15 \mathrm{H}-3,47$ & 75.95 & 6.21 & 51.73 & 6.74 & 0.022 & 0.53 & 24.4 \\
& & & & & & & \\
$317-\mathrm{U} 1354 \mathrm{C}-$ & & & & & & & \\
$2 \mathrm{H}-2,70$ & 67.20 & 2.39 & 19.94 & 2.84 & 0.039 & 0.45 & 11.3 \\
$3 \mathrm{H}-3,57$ & 74.86 & 5.02 & 41.84 & 5.04 & 0.027 & 0.02 & 0.6 \\
$3 \mathrm{H}-3,63$ & 74.92 & 5.26 & 43.79 & 5.44 & 0.026 & 0.18 & 7.0 \\
$4 \mathrm{X}-2,143$ & 81.03 & 1.34 & 11.15 & 1.79 & 0.045 & 0.45 & 10.0 \\
\hline
\end{tabular}

Notes: Inorganic carbon (IC) is from coulometric measurement of acid-evolved $\mathrm{CO}_{2}$. $\mathrm{CaCO}_{3}$ is calculated from IC $\times 8.33$. Total carbon (TC) and total nitrogen $(\mathrm{TN})$ are from elemental analyses of sediments. $\mathrm{TOC}_{\mathrm{DIFF}}=$ total organic carbon from difference of TC and IC. 
Table T18. Composition of interstitial waters, Site U1354. (See table notes.) (Continued on next page.)

\begin{tabular}{|c|c|c|c|c|c|c|c|c|c|c|c|c|}
\hline \multirow{2}{*}{$\begin{array}{l}\text { Core, section, } \\
\text { interval }(\mathrm{cm})\end{array}$} & \multirow{2}{*}{$\begin{array}{c}\text { Depth } \\
\text { CSF-A (m) }\end{array}$} & \multirow{2}{*}{$\begin{array}{l}\text { IW volume } \\
(\mathrm{mL} / \mathrm{cm})\end{array}$} & \multirow[b]{2}{*}{ Salinity } & \multirow[b]{2}{*}{$\mathrm{pH}$} & \multirow{2}{*}{$\begin{array}{c}\text { Alkalinity } \\
(\mathrm{mM})\end{array}$} & \multicolumn{6}{|c|}{ Ion chromatograph data $(\mathrm{mM})$} & \multirow[b]{2}{*}{$\mathrm{Mg} / \mathrm{Ca}$} \\
\hline & & & & & & $\mathrm{Cl}^{-}$ & $\mathrm{SO}_{4}{ }^{2-}$ & $\mathrm{Mg}^{2+}$ & $\mathrm{Ca}^{2+}$ & $\mathrm{Na}^{+}$ & $\mathrm{K}^{+}$ & \\
\hline 317-U1354A- & & & & & & & & & & & & \\
\hline $1 \mathrm{H}-1,130$ & 1.30 & 5.4 & 3.4 & 7.26 & 3.08 & 543 & 27.92 & 52.2 & 10.2 & 467 & 10.7 & 5.12 \\
\hline $1 \mathrm{H}-2,140$ & 2.90 & 3.5 & 3.4 & 7.50 & 3.30 & 535 & 27.34 & 51.1 & 10.1 & 460 & 10.6 & 5.08 \\
\hline $1 \mathrm{H}-3,68$ & 3.68 & 1.2 & 3.4 & 7.79 & 3.08 & 544 & 28.18 & 52.6 & 10.2 & 469 & 11.0 & 5.14 \\
\hline $2 \mathrm{H}-1,130$ & 5.10 & 3.4 & 3.4 & 7.40 & 4.65 & 556 & 26.50 & 51.7 & 10.1 & 481 & 10.8 & 5.14 \\
\hline $2 \mathrm{H}-2,140$ & 6.70 & 2.0 & 3.4 & 7.34 & 5.80 & 524 & 23.37 & 47.7 & 9.2 & 458 & 9.7 & 5.20 \\
\hline $2 \mathrm{H}-3,140$ & 8.20 & 2.4 & 3.4 & 7.41 & 6.11 & 548 & 23.15 & 48.9 & 9.2 & 477 & 10.2 & 5.32 \\
\hline $2 \mathrm{H}-4,140$ & 9.70 & 3.0 & 3.4 & 7.24 & 7.54 & 549 & 20.98 & 47.4 & 8.9 & 480 & 9.7 & 5.35 \\
\hline $2 \mathrm{H}-5,140$ & 11.20 & 2.8 & 3.4 & 7.41 & 7.85 & 547 & 19.36 & 45.3 & 8.2 & 480 & 9.6 & 5.56 \\
\hline $2 \mathrm{H}-6,86$ & 12.16 & 3.6 & 3.4 & 7.29 & 8.78 & 550 & 17.68 & 45.0 & 8.2 & 484 & 9.2 & 5.50 \\
\hline $6 \mathrm{H}-1,130$ & 17.60 & 2.5 & 3.3 & 7.22 & 9.84 & 564 & 11.43 & 40.3 & 7.0 & 498 & 8.1 & 5.79 \\
\hline $6 \mathrm{H}-2,140$ & 19.20 & 2.4 & 3.3 & 7.23 & 9.67 & 563 & 10.04 & 39.2 & 6.8 & 501 & 8.0 & 5.79 \\
\hline $6 \mathrm{H}-3,140$ & 20.70 & 2.5 & 3.4 & 7.27 & 10.03 & 568 & 8.84 & 37.8 & 6.6 & 501 & 7.6 & 5.72 \\
\hline $6 \mathrm{H}-4,140$ & 22.20 & 2.1 & 3.3 & 7.67 & 9.66 & 561 & 7.26 & 35.7 & 5.7 & 499 & 7.5 & 6.32 \\
\hline $6 \mathrm{H}-5,140$ & 23.58 & 2.2 & 3.3 & 7.73 & 10.11 & 561 & 8.46 & 36.7 & 6.4 & 497 & 7.3 & 5.71 \\
\hline $7 \mathrm{H}-2,140$ & 27.39 & 2.3 & 3.3 & 7.46 & 9.69 & 559 & 6.70 & 35.4 & 6.1 & 495 & 7.1 & 5.84 \\
\hline $8 \mathrm{H}-1,130$ & 32.60 & 1.9 & 3.4 & 7.37 & 10.32 & 591 & 2.16 & 32.5 & 6.8 & 523 & 6.8 & 4.79 \\
\hline $8 \mathrm{H}-2,140$ & 34.20 & 3.0 & 3.3 & 7.38 & 10.24 & 582 & 0.00 & 31.9 & 6.6 & 515 & 6.5 & 4.84 \\
\hline $8 \mathrm{H}-3,140$ & 35.70 & 2.8 & 3.4 & 7.30 & 10.31 & 600 & 0.00 & 31.6 & 7.0 & 530 & 6.8 & 4.49 \\
\hline $8 \mathrm{H}-4,140$ & 37.20 & 3.3 & 3.3 & 7.31 & 9.98 & 601 & 0.00 & 31.6 & 7.0 & 530 & 6.6 & 4.51 \\
\hline $8 \mathrm{H}-5,74$ & 38.04 & 3.5 & 3.3 & 7.34 & 9.41 & 580 & 2.12 & 31.9 & 6.8 & 514 & 6.5 & 4.67 \\
\hline $9 \mathrm{H}-1,130$ & 39.60 & 4.2 & 3.4 & 7.10 & 9.87 & 580 & 0.00 & 30.4 & 6.8 & 514 & 6.3 & 4.45 \\
\hline $9 \mathrm{H}-2,140$ & 41.20 & 4.0 & 3.4 & 7.33 & 8.76 & 607 & 0.00 & 31.6 & 6.6 & 541 & 6.5 & 4.78 \\
\hline $9 \mathrm{H}-3,140$ & 42.70 & 3.0 & 3.4 & 7.26 & 9.86 & 597 & 0.00 & 30.9 & 7.2 & 527 & 6.2 & 4.31 \\
\hline $9 \mathrm{H}-4,140$ & 44.20 & 4.0 & 3.5 & 7.22 & 9.57 & 587 & 0.00 & 30.4 & 7.1 & 519 & 6.1 & 4.29 \\
\hline $9 \mathrm{H}-5,140$ & 45.70 & 4.6 & 3.5 & 7.36 & 9.47 & 604 & 0.00 & 31.1 & 7.3 & 531 & 6.1 & 4.27 \\
\hline $9 \mathrm{H}-6,80$ & 46.60 & 2.0 & 3.4 & 7.21 & 8.97 & 605 & 0.00 & 31.7 & 7.2 & 541 & 6.1 & 4.38 \\
\hline $10 \mathrm{H}-1,130$ & 48.20 & 4.0 & 3.4 & 7.33 & 8.77 & 595 & 0.00 & 30.7 & 6.9 & 526 & 6.1 & 4.44 \\
\hline $10 \mathrm{H}-2,140$ & 49.80 & 2.3 & 3.5 & 7.31 & 9.37 & 613 & 0.00 & 31.9 & 7.4 & 541 & 6.2 & 4.30 \\
\hline $10 \mathrm{H}-3,140$ & 51.30 & 2.5 & 3.5 & 7.37 & 8.29 & 620 & 0.00 & 32.1 & 7.3 & 548 & 6.1 & 4.37 \\
\hline $10 \mathrm{H}-4,140$ & 52.80 & 3.6 & 3.4 & 7.11 & 9.07 & 611 & 0.00 & 31.6 & 7.5 & 541 & 5.9 & 4.20 \\
\hline $10 \mathrm{H}-5,68$ & 53.58 & 2.8 & 3.5 & 7.21 & 8.56 & 592 & 0.00 & 30.7 & 7.1 & 526 & 5.7 & 4.31 \\
\hline $11 \mathrm{H}-1,130$ & 55.10 & 3.6 & 3.5 & 7.40 & 7.76 & 603 & 0.00 & 30.8 & 7.0 & 532 & 6.1 & 4.39 \\
\hline $11 \mathrm{H}-2,94$ & 56.24 & 2.7 & 3.4 & 7.25 & 9.10 & 600 & 0.00 & 31.9 & 7.7 & 532 & 5.6 & 4.16 \\
\hline $12 \mathrm{H}-1,130$ & 57.60 & 3.0 & 3.4 & 7.30 & 8.18 & 603 & 0.00 & 31.8 & 7.6 & 531 & 5.8 & 4.16 \\
\hline $12 \mathrm{H}-2,140$ & 59.20 & 1.8 & 3.5 & 7.43 & 8.18 & 620 & 0.00 & 32.8 & 8.0 & 549 & 5.9 & 4.09 \\
\hline $12 \mathrm{H}-3,140$ & 60.70 & 2.3 & 3.5 & 7.24 & 8.14 & 596 & 1.27 & 31.8 & 7.8 & 528 & 5.5 & 4.09 \\
\hline $12 \mathrm{H}-4,140$ & 62.20 & 2.5 & 3.5 & 7.43 & 8.06 & 614 & 1.59 & 32.6 & 8.1 & 541 & 5.7 & 4.01 \\
\hline $12 \mathrm{H}-5,140$ & 63.70 & 3.0 & 3.5 & 7.43 & 7.70 & 624 & 2.00 & 33.1 & 8.2 & 550 & 5.8 & 4.02 \\
\hline $12 \mathrm{H}-6,87$ & 64.67 & 2.9 & 3.5 & 7.33 & 7.42 & 610 & 1.81 & 32.7 & 8.0 & 542 & 5.5 & 4.11 \\
\hline $13 \mathrm{H}-1,130$ & 66.20 & 3.2 & 3.5 & 7.45 & 6.45 & 597 & 2.24 & 31.8 & 7.5 & 528 & 5.7 & 4.22 \\
\hline $13 \mathrm{H}-2,140$ & 67.80 & 3.0 & 3.5 & 7.36 & 7.36 & 610 & 2.94 & 33.1 & 8.3 & 540 & 5.4 & 3.98 \\
\hline $13 \mathrm{H}-3,140$ & 69.30 & 2.5 & 3.4 & 7.36 & 7.42 & 623 & 3.24 & 33.3 & 8.6 & 550 & 5.4 & 3.89 \\
\hline $13 \mathrm{H}-4,140$ & 70.80 & 2.7 & 3.4 & 7.36 & 6.17 & 609 & 3.01 & 32.4 & 8.1 & 537 & 5.5 & 4.02 \\
\hline $13 \mathrm{H}-5,140$ & 72.30 & 2.9 & 3.5 & 7.32 & 7.02 & 613 & 0.00 & 33.4 & 8.4 & 543 & 5.2 & 3.95 \\
\hline $13 \mathrm{H}-6,61$ & 73.17 & 2.9 & 3.5 & 7.33 & 6.62 & 617 & 3.58 & 33.7 & 8.5 & 550 & 5.2 & 3.95 \\
\hline $14 \mathrm{H}-1,130$ & 74.90 & 2.4 & 3.5 & 7.29 & 6.49 & 592 & 4.62 & 32.8 & 8.3 & 526 & 4.8 & 3.94 \\
\hline $14 \mathrm{H}-2,96$ & 76.06 & 2.9 & 3.4 & 7.39 & 6.36 & 621 & 5.47 & 34.2 & 8.8 & 550 & 5.3 & 3.88 \\
\hline $17 \mathrm{H}-1,80$ & 79.10 & 2.8 & 3.5 & 7.43 & 5.32 & 596 & 4.56 & 32.8 & 8.2 & 531 & 4.9 & 4.02 \\
\hline $19 \mathrm{H}-1,130$ & 81.70 & 2.9 & 3.5 & 7.27 & 5.38 & 590 & 5.34 & 32.4 & 8.7 & 520 & 4.7 & 3.73 \\
\hline $19 \mathrm{H}-3,90$ & 84.30 & 3.4 & 3.6 & 7.14 & 5.67 & 612 & 5.93 & 34.4 & 9.2 & 544 & 4.6 & 3.73 \\
\hline Surface seawater & - & - & 3.4 & 7.71 & 2.32 & 543 & 27.93 & 52.9 & 10.2 & 467 & 10.1 & 5.20 \\
\hline 317-U1354C- & & & & & & & & & & & & \\
\hline $4 X-3,140$ & 82.50 & 3.0 & 3.6 & 7.23 & 5.16 & 600 & 5.19 & 32.8 & 8.9 & 526 & 4.6 & 3.70 \\
\hline $5 X-3,114$ & 86.44 & 2.7 & 3.5 & 7.50 & 5.06 & 638 & 6.82 & 35.2 & 10.0 & 562 & 4.8 & 3.53 \\
\hline $6 X-4,87$ & 97.27 & 2.8 & 3.5 & 7.51 & 4.67 & 588 & 7.86 & 33.5 & 9.7 & 516 & 4.4 & 3.46 \\
\hline $7 X-2,140$ & 104.40 & 3.8 & 3.5 & 7.59 & 3.46 & 587 & 8.01 & 33.8 & 9.5 & 517 & 4.2 & 3.57 \\
\hline $8 X-3,110$ & 110.60 & 1.9 & 3.5 & 7.33 & 4.08 & 618 & 9.17 & 36.2 & 10.5 & 545 & 3.9 & 3.43 \\
\hline $9 X-3,140$ & 120.50 & 2.0 & 3.5 & 7.57 & 3.98 & 589 & 9.11 & 35.1 & 10.5 & 520 & 3.5 & 3.36 \\
\hline $10 X-4,140$ & 131.50 & 3.0 & 3.5 & 7.54 & 3.21 & 608 & 10.44 & 36.5 & 10.9 & 534 & 3.4 & 3.36 \\
\hline $11 X-5,140$ & 142.50 & 4.3 & 3.5 & 7.40 & 2.85 & 603 & 11.48 & 37.5 & 11.1 & 531 & 3.1 & 3.37 \\
\hline $12 X-5,90$ & 151.60 & 3.2 & 3.6 & 7.50 & 2.94 & 583 & 12.51 & 37.0 & 11.3 & 511 & 3.2 & 3.27 \\
\hline $13 X-4,140$ & 160.20 & 2.8 & 3.5 & 7.52 & 2.65 & 600 & 13.99 & 39.0 & 11.8 & 524 & 3.2 & 3.30 \\
\hline $14 X-1,132$ & 165.22 & 1.2 & 3.6 & 7.49 & 2.55 & 620 & 16.25 & 41.8 & 13.0 & 541 & 4.2 & 3.21 \\
\hline $15 X-3,140$ & 177.90 & 2.8 & 3.6 & 7.47 & 2.36 & 610 & 16.41 & 41.1 & 13.1 & 531 & 3.5 & 3.14 \\
\hline $18 \mathrm{X}-2,140$ & 205.20 & 3.0 & 3.5 & 7.38 & 3.78 & 621 & 0.00 & 37.7 & 9.3 & 538 & 2.9 & 4.05 \\
\hline $19 X-2,140$ & 214.70 & 1.9 & 3.5 & 7.64 & 4.25 & 626 & 0.00 & 36.8 & 8.6 & 542 & 2.9 & 4.27 \\
\hline $21 X-3,140$ & 235.40 & 2.2 & 3.6 & 7.37 & 3.01 & 624 & 0.00 & 35.1 & 11.6 & 535 & 2.9 & 3.03 \\
\hline
\end{tabular}


Table T18 (continued).

\begin{tabular}{|c|c|c|c|c|c|c|c|c|c|c|c|c|}
\hline \multirow{2}{*}{$\begin{array}{l}\text { Core, section, } \\
\text { interval }(\mathrm{cm})\end{array}$} & \multirow{2}{*}{$\begin{array}{l}\text { Depth } \\
\text { CSF-A (m) }\end{array}$} & \multirow{2}{*}{$\begin{array}{l}\text { IW volume } \\
(\mathrm{mL} / \mathrm{cm})\end{array}$} & \multirow[b]{2}{*}{ Salinity } & \multirow[b]{2}{*}{$\mathrm{pH}$} & \multirow{2}{*}{$\begin{array}{l}\text { Alkalinity } \\
(\mathrm{mM})\end{array}$} & \multicolumn{6}{|c|}{ lon chromatograph data $(\mathrm{mM})$} & \multirow[b]{2}{*}{$\mathrm{Mg} / \mathrm{Ca}$} \\
\hline & & & & & & $\mathrm{Cl}^{-}$ & $\mathrm{SO}_{4}^{2-}$ & $\mathrm{Mg}^{2+}$ & $\mathrm{Ca}^{2+}$ & $\mathrm{Na}^{+}$ & $\mathrm{K}^{+}$ & \\
\hline $22 X-3,140$ & 244.90 & 1.4 & 3.7 & 7.50 & 2.61 & 636 & 0.00 & 35.9 & 12.5 & 549 & 3.0 & 2.88 \\
\hline $27 X-2,135$ & 291.35 & 1.8 & 3.8 & 7.21 & 2.21 & 639 & 0.00 & 36.1 & 14.3 & 545 & 3.4 & 2.52 \\
\hline $28 X-1,112$ & 299.22 & 1.0 & 3.8 & 7.41 & 2.07 & 682 & 0.00 & 37.3 & 15.1 & 581 & 4.3 & 2.46 \\
\hline $30 X-1,119$ & 318.19 & 1.8 & 3.8 & 7.67 & 2.17 & 694 & 0.00 & 37.2 & 15.6 & 591 & 4.7 & 2.38 \\
\hline
\end{tabular}

Notes: IW $=$ interstitial water. $-=$ not applicable.

Table T19. Composition of interstitial waters, Site U1354. (See table notes.) (Continued on next page.)

\begin{tabular}{|c|c|c|c|c|c|c|c|c|c|c|c|c|}
\hline \multirow[b]{2}{*}{$\begin{array}{l}\text { Core, section, } \\
\text { interval }(\mathrm{cm})\end{array}$} & \multirow[b]{2}{*}{$\begin{array}{l}\text { Depth } \\
\text { CSF-A (m) }\end{array}$} & \multicolumn{3}{|c|}{ Spectrophotometry data } & \multicolumn{7}{|c|}{ ICP-AES data } & \multirow[b]{2}{*}{$\mathrm{Sr} / \mathrm{Ca}^{*}$} \\
\hline & & $\begin{array}{l}\mathrm{NH}_{4}^{+} \\
(\mathrm{mM})\end{array}$ & $\begin{array}{l}\mathrm{HPO}_{4}^{2-} \\
(\mu \mathrm{M})\end{array}$ & $\begin{array}{l}\mathrm{HSiO}_{4} \\
(\mu \mathrm{M})\end{array}$ & $\begin{array}{c}\mathrm{Mn} \\
(\mu \mathrm{M})\end{array}$ & $\begin{array}{c}\mathrm{Fe} \\
(\mu \mathrm{M})\end{array}$ & $\begin{array}{c}\text { B } \\
(\mathrm{mM})\end{array}$ & $\begin{array}{l}\mathrm{Sr}^{2+} \\
(\mathrm{mM})\end{array}$ & $\begin{array}{c}\mathrm{Ba} \\
(\mu \mathrm{M})\end{array}$ & $\begin{array}{c}\mathrm{Si} \\
(\mu \mathrm{M})\end{array}$ & $\begin{array}{c}\mathrm{Li}^{+} \\
(\mu \mathrm{M})\end{array}$ & \\
\hline \multicolumn{13}{|l|}{ 317-U1354A- } \\
\hline $1 \mathrm{H}-1,130$ & 1.30 & ND & 4.75 & ND & 4.9 & 15.2 & 0.42 & 0.090 & 0.01 & 188 & 26 & 0.009 \\
\hline $1 \mathrm{H}-2,140$ & 2.90 & ND & 7.13 & ND & 6.0 & 15.7 & 0.41 & 0.088 & 0.19 & 378 & 26 & 0.009 \\
\hline $1 \mathrm{H}-3,68$ & 3.68 & ND & 2.70 & ND & 3.0 & 10.2 & 0.38 & 0.090 & 0.52 & 311 & 28 & 0.009 \\
\hline $2 \mathrm{H}-1,130$ & 5.10 & ND & 6.85 & ND & 6.5 & 14.2 & 0.44 & 0.162 & 0.90 & 506 & 29 & 0.016 \\
\hline $2 \mathrm{H}-2,140$ & 6.70 & ND & 7.01 & ND & 7.7 & 17.2 & 0.44 & 0.201 & 0.93 & 407 & 30 & 0.022 \\
\hline $2 \mathrm{H}-3,140$ & 8.20 & ND & 11.56 & ND & 7.4 & 17.2 & 0.44 & 0.221 & 1.02 & 456 & 30 & 0.024 \\
\hline $2 \mathrm{H}-4,140$ & 9.70 & ND & 13.86 & ND & 7.7 & 20.4 & 0.48 & 0.276 & 1.23 & 564 & 35 & 0.031 \\
\hline $2 \mathrm{H}-5,140$ & 11.20 & ND & 11.55 & ND & 5.8 & 13.9 & 0.50 & 0.313 & 1.34 & 533 & 37 & 0.038 \\
\hline $2 \mathrm{H}-6,86$ & 12.16 & ND & 9.12 & ND & 8.9 & 22.0 & 0.52 & 0.351 & 1.33 & 595 & 39 & 0.043 \\
\hline $6 \mathrm{H}-1,130$ & 17.60 & ND & 11.16 & ND & 8.2 & 20.5 & 0.61 & 0.438 & 1.85 & 434 & 41 & 0.063 \\
\hline $6 \mathrm{H}-2,140$ & 19.20 & ND & 10.76 & ND & 3.1 & 9.8 & 0.62 & 0.442 & 1.99 & 380 & 41 & 0.065 \\
\hline $6 \mathrm{H}-3,140$ & 20.70 & ND & 10.74 & ND & 3.3 & 8.6 & 0.60 & 0.423 & 1.92 & 418 & 38 & 0.064 \\
\hline $6 \mathrm{H}-4,140$ & 22.20 & ND & 4.73 & ND & 7.7 & 15.5 & 0.59 & 0.371 & 1.99 & 364 & 40 & 0.066 \\
\hline $6 \mathrm{H}-5,140$ & 23.58 & ND & 7.21 & ND & 8.0 & 17.7 & 0.63 & 0.463 & 2.47 & 435 & 41 & 0.072 \\
\hline $7 \mathrm{H}-2,140$ & 27.39 & ND & 6.10 & ND & 7.4 & 15.5 & 0.62 & 0.420 & 2.15 & 400 & 38 & 0.069 \\
\hline $8 \mathrm{H}-1,130$ & 32.60 & ND & 8.66 & ND & 4.1 & 9.5 & 0.70 & 0.480 & 2.20 & 364 & 42 & 0.071 \\
\hline $8 \mathrm{H}-2,140$ & 34.20 & ND & 8.67 & ND & 3.9 & 9.0 & 0.72 & 0.488 & 2.35 & 370 & 41 & 0.074 \\
\hline $8 \mathrm{H}-3,140$ & 35.70 & ND & 9.19 & ND & 3.9 & 10.8 & 0.76 & 0.482 & 2.21 & 456 & 40 & 0.069 \\
\hline $8 \mathrm{H}-4,140$ & 37.20 & ND & 9.37 & ND & 3.7 & 9.0 & 0.72 & 0.478 & 2.40 & 511 & 39 & 0.068 \\
\hline $8 \mathrm{H}-5,74$ & 38.04 & ND & 8.77 & ND & 6.7 & 15.9 & 0.74 & 0.472 & 2.24 & 461 & 40 & 0.069 \\
\hline $9 \mathrm{H}-1,130$ & 39.60 & ND & 10.34 & ND & 3.6 & 13.3 & 0.78 & 0.496 & 2.08 & 465 & 40 & 0.073 \\
\hline $9 \mathrm{H}-2,140$ & 41.20 & ND & 8.52 & ND & 6.9 & 14.9 & 0.78 & 0.494 & 1.93 & 433 & 39 & 0.075 \\
\hline $9 \mathrm{H}-3,140$ & 42.70 & ND & 8.52 & ND & 3.4 & 9.2 & 0.76 & 0.491 & 2.12 & 458 & 36 & 0.068 \\
\hline $9 \mathrm{H}-4,140$ & 44.20 & ND & 8.71 & ND & 3.4 & 10.3 & 0.80 & 0.518 & 2.21 & 509 & 37 & 0.073 \\
\hline $9 \mathrm{H}-5,140$ & 45.70 & ND & 7.52 & ND & 3.1 & 8.9 & 0.78 & 0.496 & 2.34 & 551 & 36 & 0.068 \\
\hline $9 \mathrm{H}-6,80$ & 46.60 & ND & 7.66 & ND & 7.1 & 17.7 & 0.83 & 0.523 & 2.16 & 505 & 37 & 0.072 \\
\hline $10 \mathrm{H}-1,130$ & 48.20 & ND & 6.98 & ND & 3.2 & 9.4 & 0.82 & 0.524 & 2.20 & 453 & 40 & 0.076 \\
\hline $10 \mathrm{H}-2,140$ & 49.80 & ND & 5.63 & ND & 3.1 & 9.6 & 0.80 & 0.517 & 2.60 & 459 & 39 & 0.070 \\
\hline $10 \mathrm{H}-3,140$ & 51.30 & ND & 6.18 & ND & 2.7 & 9.6 & 0.81 & 0.513 & 2.12 & 438 & 36 & 0.070 \\
\hline $10 \mathrm{H}-4,140$ & 52.80 & ND & 5.93 & ND & 2.7 & 9.2 & 0.82 & 0.516 & 2.25 & 473 & 35 & 0.069 \\
\hline $10 \mathrm{H}-5,68$ & 53.58 & ND & 4.84 & ND & 6.7 & 16.5 & 0.83 & 0.517 & 2.48 & 664 & 35 & 0.073 \\
\hline $11 \mathrm{H}-1,130$ & 55.10 & ND & 4.07 & ND & 3.3 & 9.6 & 0.84 & 0.533 & 2.53 & 474 & 38 & 0.076 \\
\hline $11 \mathrm{H}-2,94$ & 56.24 & ND & 2.86 & ND & 6.9 & 27.6 & 0.85 & 0.524 & 2.42 & 472 & 35 & 0.068 \\
\hline $12 \mathrm{H}-1,130$ & 57.60 & ND & 2.62 & ND & 4.4 & 10.2 & 0.82 & 0.545 & 2.50 & 369 & 34 & 0.071 \\
\hline $12 \mathrm{H}-2,140$ & 59.20 & ND & 2.92 & ND & 4.5 & 10.1 & 0.86 & 0.572 & 2.75 & 381 & 35 & 0.071 \\
\hline $12 \mathrm{H}-3,140$ & 60.70 & ND & 2.17 & ND & 7.4 & 17.1 & 0.87 & 0.580 & 2.77 & 424 & 34 & 0.075 \\
\hline $12 \mathrm{H}-4,140$ & 62.20 & ND & 2.88 & ND & 4.3 & 10.3 & 0.83 & 0.556 & 2.87 & 420 & 32 & 0.068 \\
\hline $12 \mathrm{H}-5,140$ & 63.70 & ND & 2.91 & ND & 4.5 & 10.5 & 0.89 & 0.606 & 2.70 & 399 & 33 & 0.074 \\
\hline $12 \mathrm{H}-6,87$ & 64.67 & ND & 3.01 & ND & 6.8 & 15.2 & 0.86 & 0.569 & 2.81 & 459 & 31 & 0.072 \\
\hline $13 \mathrm{H}-1,130$ & 66.20 & ND & 2.71 & ND & 3.2 & 9.8 & 0.86 & 0.570 & 2.67 & 353 & 31 & 0.076 \\
\hline $13 \mathrm{H}-2,140$ & 67.80 & ND & 2.66 & ND & 6.0 & 15.7 & 0.79 & 0.518 & 3.00 & 586 & 27 & 0.062 \\
\hline $13 \mathrm{H}-3,140$ & 69.30 & ND & 2.39 & ND & 3.1 & 10.7 & 0.88 & 0.577 & 2.39 & 417 & 30 & 0.067 \\
\hline $13 \mathrm{H}-4,140$ & 70.80 & ND & 1.83 & ND & 2.8 & 9.6 & 0.87 & 0.559 & 2.41 & 442 & 29 & 0.069 \\
\hline $13 \mathrm{H}-5,140$ & 72.30 & ND & 2.51 & ND & 5.1 & 15.0 & 0.90 & 0.584 & 2.48 & 585 & 27 & 0.069 \\
\hline $13 \mathrm{H}-6,61$ & 73.07 & ND & 2.40 & ND & 7.5 & 18.1 & 0.95 & 0.591 & 2.17 & 548 & 27 & 0.069 \\
\hline $14 \mathrm{H}-1,130$ & 74.90 & ND & 2.42 & ND & 6.0 & 16.9 & 0.93 & 0.605 & 2.30 & 640 & 25 & 0.073 \\
\hline $14 \mathrm{H}-2,96$ & 75.62 & ND & 2.24 & ND & 2.8 & 10.1 & 0.88 & 0.565 & 1.99 & 429 & 26 & 0.064 \\
\hline $17 \mathrm{H}-1,80$ & 79.10 & ND & 1.40 & ND & 6.2 & 16.6 & 0.90 & 0.545 & 1.76 & 502 & 24 & 0.070 \\
\hline $19 \mathrm{H}-1,130$ & 81.70 & ND & 1.34 & ND & 2.7 & 10.7 & 0.90 & 0.585 & 1.90 & 460 & 22 & 0.067 \\
\hline $19 \mathrm{H}-3,90$ & 84.30 & ND & 1.38 & ND & 7.2 & 20.9 & 0.93 & 0.591 & 1.87 & 551 & 21 & 0.064 \\
\hline Surface seawater & - & ND & 0.38 & ND & 2.7 & 11.7 & 0.40 & 0.089 & 0.11 & 83 & 24 & 0.009 \\
\hline
\end{tabular}


Table T19 (continued).

\begin{tabular}{|c|c|c|c|c|c|c|c|c|c|c|c|c|}
\hline \multirow[b]{2}{*}{$\begin{array}{l}\text { Core, section, } \\
\text { interval }(\mathrm{cm})\end{array}$} & \multirow[b]{2}{*}{$\begin{array}{c}\text { Depth } \\
\text { CSF-A (m) }\end{array}$} & \multicolumn{3}{|c|}{ Spectrophotometry data } & \multicolumn{7}{|c|}{ ICP-AES data } & \multirow[b]{2}{*}{$\mathrm{Sr} / \mathrm{Ca}^{*}$} \\
\hline & & $\begin{array}{l}\mathrm{NH}_{4}^{+} \\
(\mathrm{mM})\end{array}$ & $\begin{array}{c}\mathrm{HPO}_{4}^{2-} \\
(\mu \mathrm{M})\end{array}$ & $\begin{array}{c}\mathrm{HSiO}_{4} \\
(\mu \mathrm{M})\end{array}$ & $\begin{array}{c}\mathrm{Mn} \\
(\mu \mathrm{M})\end{array}$ & $\begin{array}{c}\mathrm{Fe} \\
(\mu \mathrm{M})\end{array}$ & $\begin{array}{c}\mathrm{B} \\
(\mathrm{mM})\end{array}$ & $\begin{array}{c}\mathrm{Sr}^{2+} \\
(\mathrm{mM})\end{array}$ & $\begin{array}{c}\mathrm{Ba} \\
(\mu \mathrm{M})\end{array}$ & $\begin{array}{c}\mathrm{Si} \\
(\mu \mathrm{M})\end{array}$ & $\begin{array}{c}\mathrm{Li}^{+} \\
(\mu \mathrm{M})\end{array}$ & \\
\hline $4 X-3,140$ & 82.50 & ND & 1.40 & ND & 2.7 & 11.8 & 0.93 & 0.574 & 1.84 & 543 & 23 & 0.065 \\
\hline $5 X-3,114$ & 86.44 & ND & 1.49 & ND & 4.2 & 12.1 & 0.86 & 0.574 & 2.26 & 481 & 23 & 0.057 \\
\hline $6 X-4,87$ & 97.27 & ND & 1.27 & ND & 4.7 & 12.1 & 0.86 & 0.583 & 2.61 & 468 & 24 & 0.060 \\
\hline $7 X-2,140$ & 104.40 & ND & 1.00 & ND & 3.6 & 11.9 & 0.84 & 0.593 & 1.75 & 335 & 20 & 0.063 \\
\hline $8 X-3,110$ & 110.60 & ND & 0.59 & ND & 3.0 & 13.2 & 0.96 & 0.559 & 1.20 & 390 & 20 & 0.053 \\
\hline $9 X-3,140$ & 120.50 & ND & 0.73 & ND & 3.9 & 12.1 & 0.98 & 0.603 & 1.49 & 397 & 20 & 0.058 \\
\hline $10 X-4,140$ & 131.50 & ND & 0.82 & ND & 3.7 & 12.1 & 0.99 & 0.595 & 1.20 & 287 & 22 & 0.055 \\
\hline $11 X-5,140$ & 142.50 & ND & 0.79 & ND & 4.3 & 13.2 & 1.03 & 0.618 & 1.24 & 308 & 26 & 0.056 \\
\hline $12 X-5,90$ & 151.60 & ND & 0.66 & ND & 4.9 & 12.7 & 1.08 & 0.613 & 1.32 & 236 & 27 & 0.054 \\
\hline $13 X-4,140$ & 160.20 & ND & 0.55 & ND & 3.7 & 13.8 & 1.02 & 0.622 & 1.58 & 247 & 32 & 0.053 \\
\hline $14 X-1,132$ & 165.22 & ND & 0.77 & ND & 4.8 & 13.8 & 0.96 & 0.603 & 3.09 & 221 & 39 & 0.046 \\
\hline $15 X-3,140$ & 177.90 & ND & 0.49 & ND & 4.5 & 13.0 & 1.05 & 0.598 & 1.99 & 229 & 36 & 0.046 \\
\hline $19 X-2,140$ & 214.70 & ND & 0.70 & ND & 3.5 & 12.5 & 1.09 & 0.575 & 3.70 & 237 & 33 & 0.069 \\
\hline $21 X-3,140$ & 235.40 & ND & 0.49 & ND & 4.2 & 13.4 & 1.17 & 0.580 & 4.67 & 247 & 38 & 0.050 \\
\hline $22 X-3,140$ & 244.90 & ND & 0.45 & ND & 3.7 & 13.9 & 1.06 & 0.574 & 5.09 & 230 & 43 & 0.046 \\
\hline $27 X-2,135$ & 291.35 & ND & 0.43 & ND & 7.5 & 14.0 & 1.20 & 0.526 & 5.11 & 210 & 57 & 0.037 \\
\hline $28 X-1,112$ & 299.22 & ND & 0.43 & ND & 6.1 & 14.3 & 1.21 & 0.516 & 6.63 & 204 & 68 & 0.034 \\
\hline $30 x-1,119$ & 318.19 & ND & 0.53 & ND & 5.4 & 14.5 & 1.26 & 0.538 & 7.93 & 182 & 87 & 0.034 \\
\hline
\end{tabular}

Notes: ${ }^{*}=\mathrm{Ca}^{2+}$ data from ion chromatography (see Table T18). ICP-AES = inductively coupled plasma-atomic emission spectroscopy. $-=$ not applicable, ND = not determined. Mn and Fe concentrations may have been affected by oxidation prior to analysis, as these are redox-sensitive trace elements.

Table T20. Temperature data, Site U1354. (See table notes.)

\begin{tabular}{lccccccc}
\hline \multicolumn{1}{c}{ Core } & Tool & $\begin{array}{c}\text { Depth } \\
\text { CSF-A }(\mathrm{m})\end{array}$ & $\begin{array}{c}\text { Temperature } \\
\left({ }^{\circ} \mathrm{C}\right)\end{array}$ & $\begin{array}{c}t_{\mathrm{i}} \\
(\mathrm{s})\end{array}$ & $\begin{array}{c}t_{\mathrm{f}} \\
(\mathrm{s})\end{array}$ & $\begin{array}{c}t_{\mathrm{f}}-t_{\mathrm{i}} \\
(\mathrm{s})\end{array}$ & Reliability \\
\hline $317-\mathrm{U} 1354 \mathrm{C}-$ & & & & & & & \\
$14 \mathrm{X}$ & $\mathrm{SET}$ & 174.5 & 14.27 & 27 & 155 & 128 & Poor \\
$16 \mathrm{X}$ & $\mathrm{SET}$ & 193.6 & 12.84 & 118 & 256 & 138 & Poor \\
\hline
\end{tabular}

Notes: Times $t_{\mathrm{i}}$ and $t_{\mathrm{f}}$ are the initial and final times of the interval, respectively, picked to estimate asymptotic temperature for each data set. Estimated temperatures are considered reliable when the picked interval, $t_{\mathrm{f}}-t_{\mathrm{i}}$, is $>300 \mathrm{~s}$. SET $=$ Sediment Temperature tool. Measurement depth is the bottom of the last cored interval plus $1 \mathrm{~m}$, the approximate distance the temperature sensor advances beneath the bit.

Table T21. Thermal conductivity data, Site U1354. (See table notes.)

\begin{tabular}{|c|c|c|c|c|c|c|}
\hline \multirow[b]{2}{*}{ Hole } & \multicolumn{2}{|c|}{ Measurement $(N)$} & \multicolumn{2}{|c|}{ Depth CSF-A (m) } & \multicolumn{2}{|c|}{$\begin{array}{l}\text { Lab-measured thermal conductivity }{ }^{\dagger} \\
\text { (harmonic mean/range; } \mathrm{W} /[\mathrm{m} \cdot \mathrm{K}] \text { ) }\end{array}$} \\
\hline & Good* & Total & Good* & Total & Hole & Site \\
\hline \multicolumn{7}{|l|}{$317-$} \\
\hline U1354A & 17 & 35 & $0.7-82.6$ & $0.7-84.8$ & $1.492 / 1.183-1.873$ & \\
\hline U1354B & 14 & 25 & $3.2-75.9$ & $0.7-75.9$ & $1.457 / 1.332-1.778$ & $1.409 / 1.183-1.873$ \\
\hline U1354C & 23 & 43 & $70.2-336.6$ & $67.2-374.8$ & $1.398 / 1.239-1.671$ & \\
\hline
\end{tabular}

Notes: * $=$ thermal conductivity data were discarded when (1) contact between the probe and sediment was poor, (2) thermal conductivity was close to that of water $(0.6 \mathrm{~W} /[\mathrm{m} \cdot \mathrm{K}])$ because of sediment dilution during coring, or (3) measurements were taken in caved-in layers such as shell hash. $\dagger=$ good measurements. 
Table T22. Cumulative depth adjustments, Site U1354.

\begin{tabular}{|c|c|}
\hline Core & $\begin{array}{l}\text { Cumulative depth } \\
\text { adjustment }(\mathrm{m})\end{array}$ \\
\hline \multicolumn{2}{|l|}{ 317-U1354A- } \\
\hline $1 \mathrm{H}$ & 0 \\
\hline $2 \mathrm{H}$ & 0 \\
\hline $3 \mathrm{H}$ & 0 \\
\hline $4 X$ & 0 \\
\hline $5 x$ & 0 \\
\hline $6 \mathrm{H}$ & 0 \\
\hline $7 \mathrm{H}$ & 0 \\
\hline $8 \mathrm{H}$ & 0 \\
\hline $9 \mathrm{H}$ & 0.73 \\
\hline $10 \mathrm{H}$ & 0.73 \\
\hline $11 \mathrm{H}$ & 0.73 \\
\hline $12 \mathrm{H}$ & 0.73 \\
\hline $13 \mathrm{H}$ & 1.87 \\
\hline $14 \mathrm{H}$ & 1.87 \\
\hline $15 X$ & 1.87 \\
\hline $16 \mathrm{X}$ & 1.87 \\
\hline $17 \mathrm{H}$ & 1.87 \\
\hline $18 \mathrm{X}$ & 1.87 \\
\hline $19 \mathrm{H}$ & 1.87 \\
\hline \multicolumn{2}{|l|}{ 317-U1354B- } \\
\hline $1 \mathrm{H}$ & 0 \\
\hline $2 \mathrm{H}$ & 2.34 \\
\hline $3 \mathrm{H}$ & 2.34 \\
\hline $4 \mathrm{H}$ & 2.34 \\
\hline $5 \mathrm{H}$ & 2.34 \\
\hline $6 X$ & 2.34 \\
\hline $7 \mathrm{H}$ & 2.34 \\
\hline $8 \mathrm{H}$ & 4.53 \\
\hline $9 \mathrm{H}$ & 4.53 \\
\hline $10 \mathrm{H}$ & 5.91 \\
\hline $11 \mathrm{H}$ & 6.64 \\
\hline $12 \mathrm{H}$ & 6.64 \\
\hline $13 \mathrm{H}$ & 6.64 \\
\hline $14 \mathrm{H}$ & 6.64 \\
\hline $15 \mathrm{H}$ & 6.64 \\
\hline $\begin{array}{l}317-U 1354 C- \\
2 \mathrm{H} \text { through } 20 \mathrm{X}\end{array}$ & 7.29 \\
\hline
\end{tabular}

